Maria Clara Bastos

\title{
PROCESSOS DE COMPOSIÇÃO E EXPRESSÃO NA OBRA DE ITAMAR ASSUMPÇÃO
}

\author{
Dissertação apresentada à Área de Concentração: \\ Processos de Criação Musical do Departamento de \\ Música da Escola de Comunicações e Artes da \\ Universidade de São Paulo, como exigência para a \\ obtenção do Título de Mestre em Artes, sob orientação \\ do Prof. Dr. Marcos Câmara de Castro.
}

São Paulo - maio / 2012 
Dedico este trabalho a Itamar Assumpção (1949-2003) e ao meu pai Paulo Bastos (1936-2012),

guerreiros em vida. 


\section{AGRADECIMENTOS}

Ao meu orientador Marcos Câmara, que confiou em mim, e no trajeto que iríamos percorrer.

Ao Sergio Molina, por ser também meu companheiro de sons e notas, cujo amor pela música clareia a todos que estão por perto.

A todos os músicos e compositores que tocaram e compartilharam seus talentos com Itamar Assumpção. Em especial à Alice Ruiz, Arrigo Barnabé, Paulo Barnabé, e Paulo Lepetit que concederam seu tempo para conversar. À Banda Isca de Polícia, às Orquídeas do Brasil. Àqueles outros tantos músicos que teriam concedido seu tempo também, se eu houvesse solicitado, dentre eles: Alzira Espíndola, Tonho Penhasco, Gigante Brazyl (in memoriam), Suzana Salles, Luiz Waack, Tetê Espíndola, Estrela Ruiz, Luiz Chagas, Simone Sou, Miriam Maria, Denise Assunção.

À família de Itamar. À Zena, que atendeu diversos telefonemas com paciência e generosidade. À Serena que respondeu com prontidão às minhas dúvidas. À Anelis que foi cúmplice nos palcos.

À minha família: Lucilena, Fernando, Caio, Marina e Rogério, mãe e irmãos. Ao meu pai Paulo.

Ao próprio Itamar, "pai" musical, que apresentou um caminho ao qual não pude recusar em percorrer. 


\section{RESUMO}

Este trabalho estuda a obra de Itamar Assumpção, investigando os principais procedimentos de composição musical utilizados, bem como a relação que possuem com suas vivências pessoais de aprendizagem musical e teatral. Sua obra promove algumas sínteses de materiais musicais e poéticos da tradição popular brasileira e internacional, referencias que são reelaboradas no processo de criação de suas canções. São demonstradas e analisadas a confluência e a atrelagem que existe entre a ação da performance e oito matrizes composicionais identificadas ao longo das diferentes fases de sua obra.

Palavras-Chave: Itamar Assumpção; Canção Popular; Performance; Contrabaixo; Análise Musical

\section{ABSTRACT}

This paper studies the music of Itamar Assumpção, exploring not only the compositional procedures employed, but also their relation to the artist's musical and theatrical life experiences. Assumpção's work harmonizes musical and poetic material from the Brazilian and international popular tradition, a synthesis that is reconstructed in the process of songwriting. This paper demonstrates and analyzes the confluence and interconnection between the act of performance and eight compositional structures identified throughout different phases of his work.

Key words: Itamar Assumpção; Popular songwriting; Performance; Double bass; Musical analysis. 


\section{Índice}

INTRODUÇÃO

Criação e performance: estabelecimento de matrizes composicionais...................................11

CAPÍTULO 1 - CONSTRUÇÃO DA POETICIDADE MUSICAL E ARTÍSTICA NA OBRA

DE ITAMAR ASSUMPÇÃO

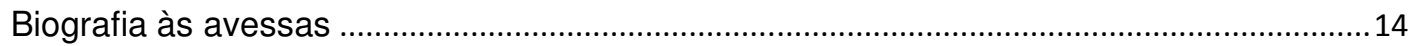

1.1 OS BATUQUES DE UMBIGADA DE TIETÊ - A RÍTMICA NA OBRA DE ITAMAR ASSUMPÇÃO

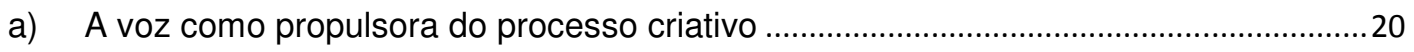

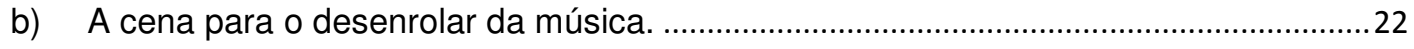

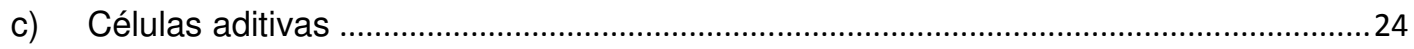

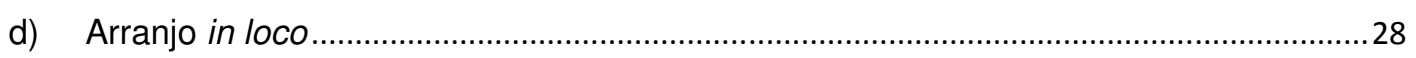

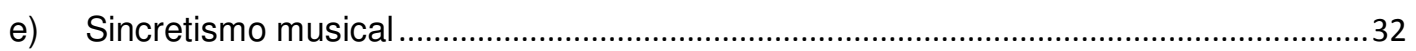

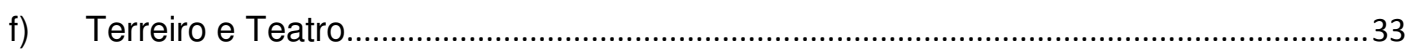

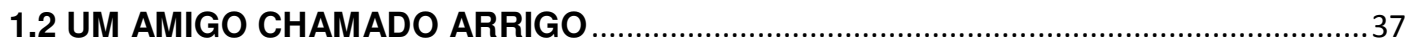

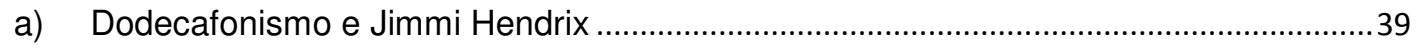

b) Diversões Eletrônicas e Infortúnio................................................................................

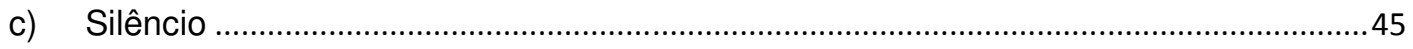

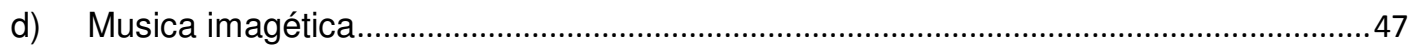

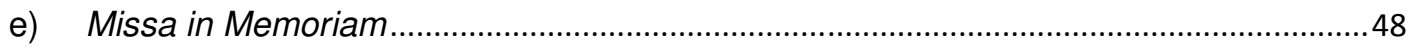

1.3 O EXERCÍCIO DA PERFORMANCE NO TEATRO LIRA PAULISTANA …..................50

A voz da vanguarda paulista e a performance...................................................................50

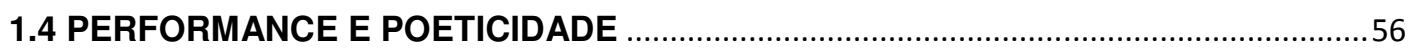

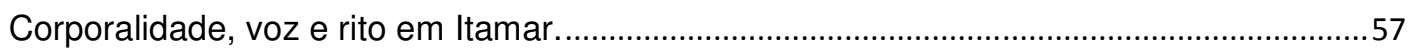

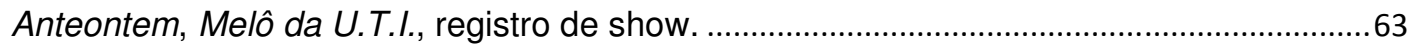

1.5 TROPICALISMO NA TEIA DA VANGUARDA PAULISTA …................................... 70

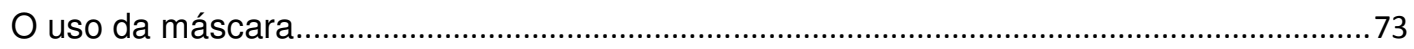

1.6 DESDOBRAMENTOS DA OBRA DE ITAMAR ASSUMPÇÃO ……...........................75

CAPÍTULO 2 - ANÁLISE DAS COMPOSIÇÕES: OITO MATRIZES .................................78

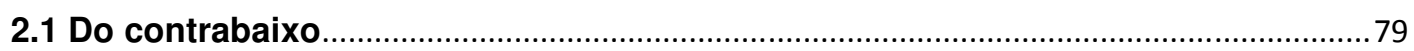

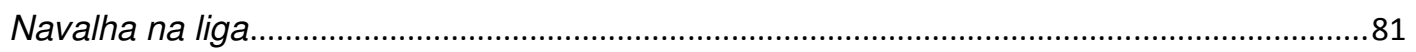

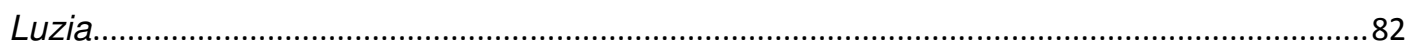

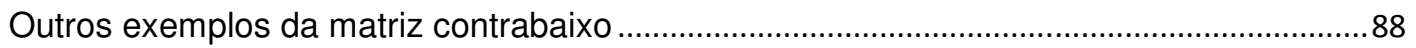




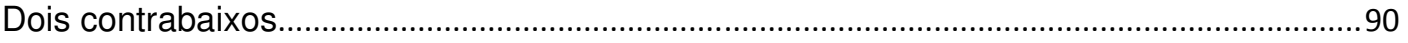

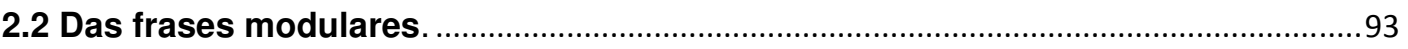

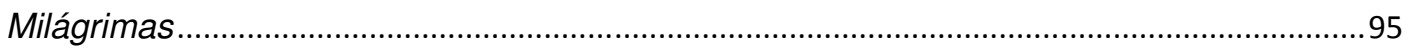

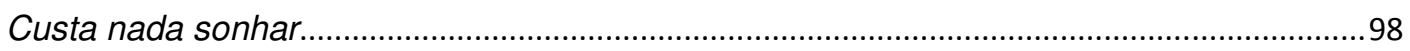

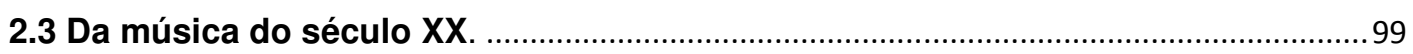

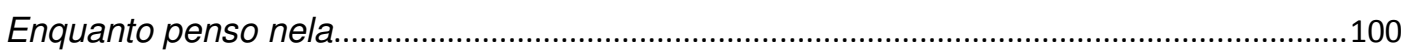

2.4 Da voz feminina, como personagem e presença.................................................103

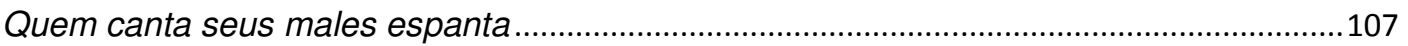

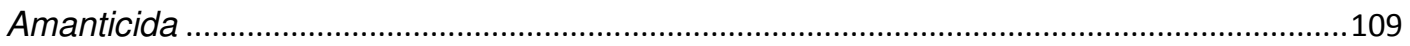

2.5 Contrabaixo e fala ritmada: quem é quem? ........................................................110

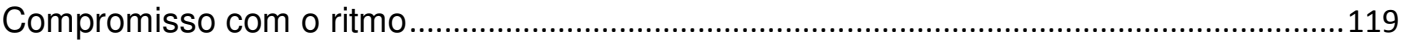

2.6 Performatividade nas composições. ......................................................................124

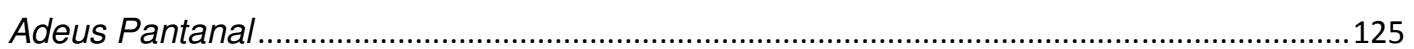

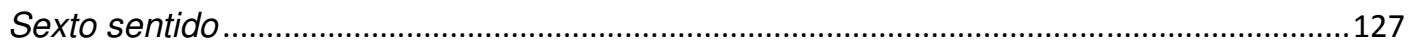

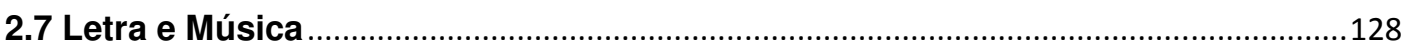

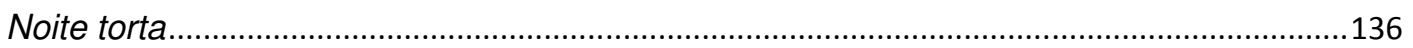

2.8 Desdobramentos da música de Itamar Assumpção .............................................140

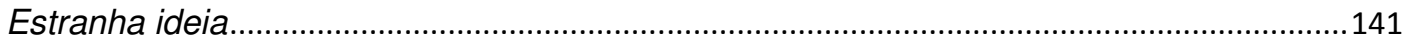

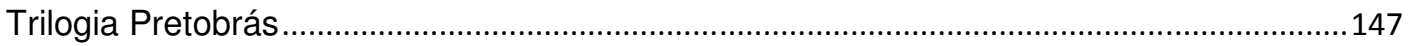

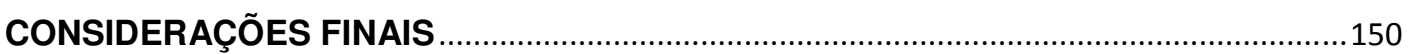

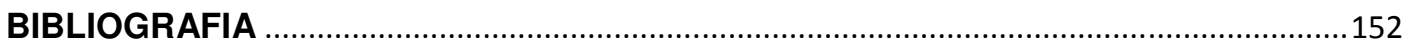

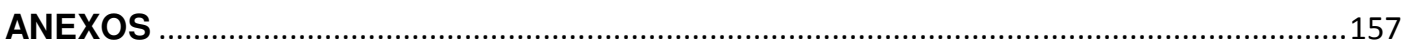

Anexo 1: Índice alfabético das canções presentes na discografia......................................157

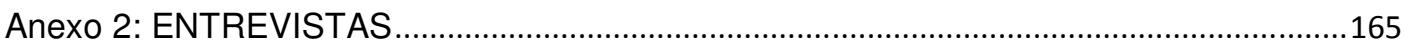

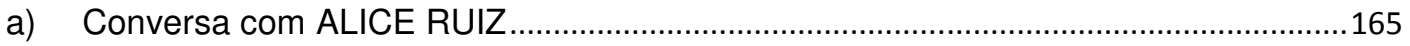

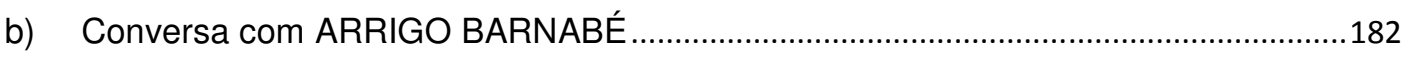

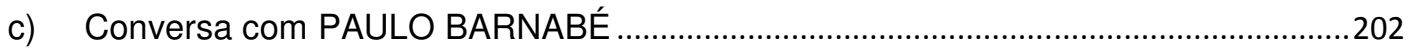

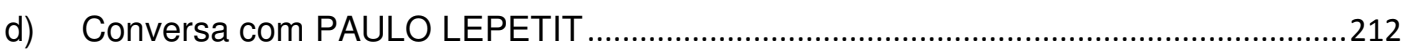

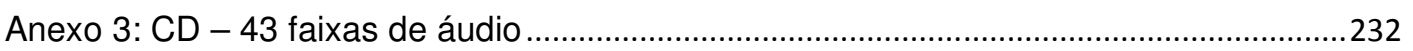

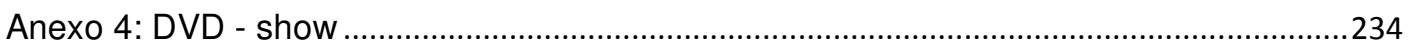




\section{ÍNDICE DE FIGURAS}

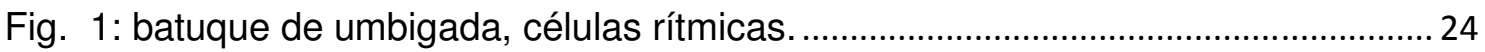

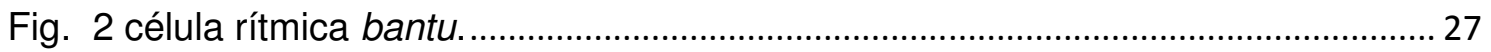

Fig. 3: ritmo do tamborim no samba, semelhante à célula rítmica bantu........................ 27

Fig. 4: Sonhei que viajava com você, polirritmia. (CD anexo, faixa 2) ........................... 32

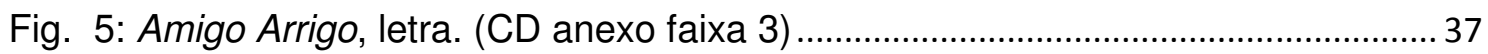

Fig. 6: linha de baixo dodecafônica de Diversões eletrônicas. (CD anexo faixa 4) ....... 42

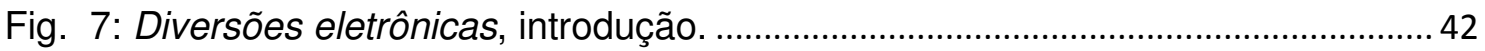

Fig. 8: Infortúnio, trecho da linha de baixo. (CD anexo faixa 5) ........................................ 44

Fig. 9 Negra melodia, arranjo de linha de baixo para a canção de Jards Macalé e Wally

Salomão, o silêncio em evidência. (CD anexo faixa 6) .................................................. 46

Fig. 10: Melô da U.T.I., duas versões da mesma música, a primeira de show (DVD

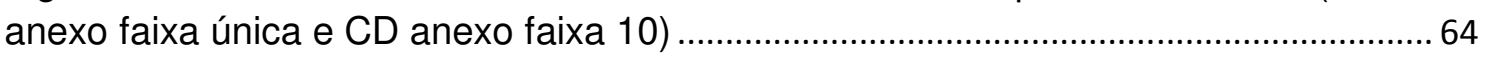

Fig. 11: Anteontem, refrão. Tonalidade de ré maior. Refrão em ré menor. .......................69

Fig. 12: Itamar Assumpção. Foto de Jorge Rosenberg.................................................. 74

Fig. 13 Navalha na Liga, melodia e linha de baixo. (CD anexo faixa 1) ......................... 81

Fig. 14 Navalha na Liga: linha de baixo sugerindo métrica assimétrica.......................... 82

Fig. 15: Luzia, polirritmia entre a linha de baixo e a voz. (CD anexo faixa 13) ............. 84

Fig. 16: Peço perdão - baixo dobrado com guitarra. (CD anexo faixa 14) ...................... 86

Fig. 17: Fico louco, linha de baixo com características de reggae e oitavada com a

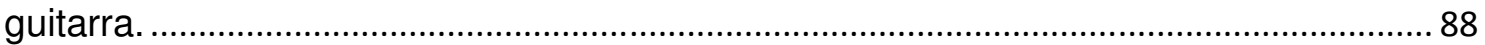

Fig. 18: Dor elegante, linha de baixo como elemento gerador da composição. (CD

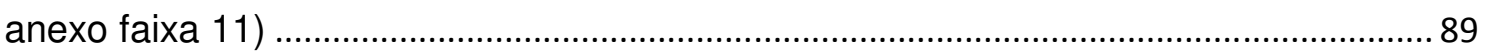

Fig. 19: In the morning, arranjo de Mario Campos para dois contrabaixos. (CD anexo faixa 16)

Fig. 20: Venha até São Paulo, arranjo de Itamar Assumpção para dois contrabaixos.92

Fig. 21: Milágrimas, melodia da primeira parte da canção. (CD anexo faixa 18) ......... 96

Fig. 22: Milágrimas, segunda seção da canção - motivos rítmicos e presença de

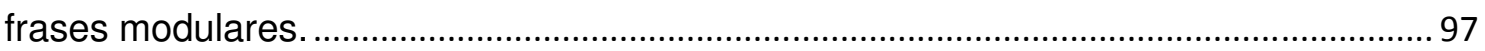

Fig. 23: Custa nada sonhar, canção com frases modulares. (CD anexo faixa 19) ...... 99

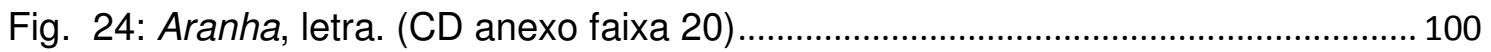

Fig. 25 Enquanto penso nela, utilização de dissonâncias. (CD anexo faixa 21) ......... 101

Fig. 26 Amigo Arrigo, linha da guitarra. (CD anexo faixa 3) ...................................... 102

Fig. 27 Amigo Arrigo, quebra da ideia de compasso e melodia com notas dissonantes.

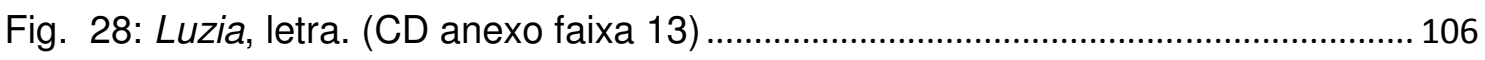

Fig. 29: Quem canta seus males espanta, letra. (CD anexo faixa 22) ........................ 107

Fig. 30 Amanticida, parceria com Maria Rosa Amoroso. (CD anexo faixa 23) ............ 110

Fig. 31: Beijo na boca. Melodia com características semelhantes à condução de uma

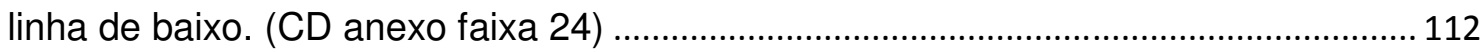

Fig. 32: Baby e Santo de casa, respectivamente refrão e linha de baixo. (CD anexo,

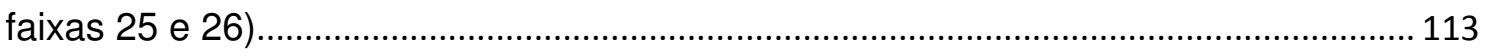

Fig. 33: Santo de casa, melodia e linha de baixo. (CD anexo faixa 26) ........................ 114

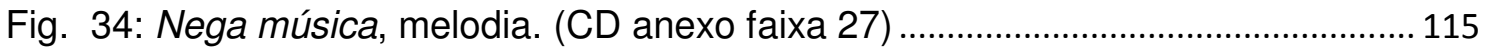

Fig. 35: Venha até São Paulo, base modular. (CD anexo faixa 17) ............................ 116 
Fig. 36: Venha até São Paulo, rap. (CD anexo faixa 17).

Fig. 37: Cultura Lira Paulistana, fala ritmada com melodia. (CD anexo faixa 28) ....... 117

Fig. 38: Orquídeas, fala ritmada e melodia para o refrão. (CD anexo faixa 29)........... 118

Fig. 39:Totalmente à revelia, canção com texto sem vínculo com a base. (CD anexo

faixa 30)

Fig. 40: Laranja madura, refrão original da canção de Ataúlfo Alves, arranjada por

Itamar Assumpção. (CD anexo faixa 31).

Fig. 41: Laranja madura, refrão rearranjado.

Fig. 42: Nego Dito, introdução. (CD anexo faixa 7)

Fig. 43: Nego dito, arranjo vocal. (CD anexo faixa 7)

Fig. 44: Adeus Pantanal, letra. (CD anexo faixa 31)

Fig. 45: Sexto sentido, primeira estrofe, frase de baixo alternando com condução de guitarra.

Fig. 46: Tristes trópicos - recurso de aliteração. (CD anexo faixa 33)........................... 131

Fig. 47: Vê se me esquece, letra da canção. (CD anexo faixa 34) ................................ 134

Fig. 48: Vê se me esquece, melodia repetitiva. (CD anexo faixa 34) ........................... 135

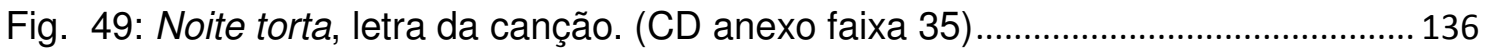

Fig. 50: Noite torta, trecho da melodia. (CD anexo faixa 35) ....................................... 138

Fig. 51: Noite torta, organização da construção melódica do segundo período da canção.

Fig. 52: Estranha ideia, poema de Itamar musicado por Sergio Molina. Presença de compassos assimétricos para respeitar a prosódia. (CD anexo faixa 36) 


\section{INTRODUÇÃO}

Conheci pessoalmente Itamar Assumpção na metade do ano de 1991 quando fui participar de meu primeiro ensaio com a banda Orquídeas do Brasil1$^{1}$. A duração desse ensaio se estendeu por mais tempo do que o combinado e quando acabou me dei conta de que tinha alguns poucos minutos para atravessar a cidade de São Paulo, na hora do rush, indo do bairro do Morumbi até o centro, na rua Dr. Vila Nova, onde me aguardava um compromisso. Itamar pegou carona comigo e foi falando sobre diversos assuntos, quase sem parar (como the era peculiar) com pequenas pausas para pensar e para escutar o que eu tinha para dizer. Ele tinha a habilidade de fazer com que seu interlocutor se sentisse à vontade, como se fora um velho amigo, e como se durante a conversa, a qualquer momento, houvesse a possibilidade de se tornar testemunha de um acontecimento muito importante. Esse talento de prender a atenção do ouvinte me parece estar espelhado também em suas composições, através de diversas recorrências, tais como a valorização dos espaços de silêncio, da pulsação, das nuances de dinâmica, de sua interpretação teatral (trazendo a atenção para sua própria figura), da presença de um discurso contundente, dentre outros aspectos. Surpreendentemente 0 tráfego de veículos fluiu e consegui chegar ao local aonde ia me apresentar tocando, no Sesc Consolação, no exato momento em que deveria subir ao palco. Ele se despediu e buscou a estação de metrô que estava mais próxima.

Essa lembrança levantada aqui tem o sentido de apontar o início da minha jornada pessoal, que me aproximou e me fez participar do trabalho artístico de Itamar Assumpção. As primeiras impressões que tive sobre ele me pareceram nítidas, e foram se confirmando durante os anos. Esta pesquisa completa, um ciclo. Não se trata de tarefa com pretensão de esgotar o assunto ou de impor-se legítima por ser oriunda de uma experiência de fonte primária. Ao contrário, creio ser necessário somar e contrapor pontos de vista, com estudos que já foram e que virão a ser realizados, pois em sua obra há

\footnotetext{
${ }^{1}$ Grupo que passou a acompanhá-lo nos shows a partir desse período, sucedendo a banda Isca de Polícia, que havia sido formada nos anos da década de 80.
} 
diversos vieses que podem ser explorados. É a diversidade de características que seu trabalho possui que permite isso.

Sobre as ferramentas musicais de composição e de expressão identificadas neste estudo foi possível entendê-las como sendo uma arregimentação, realizada por Itamar, de procedimentos que levaram à formação de um estilo, muito próprio. Seu estilo está conectado a outros processos composicionais e a outras áreas artísticas, tão ricos como os dele, ocorrentes nas culturas rural e urbana, brasileira e internacional.

No final do ano de 2002, Itamar sugeriu que eu fizesse as transcrições de todos os seus discos. Esse trabalho só foi iniciado após sua morte em junho de $2003^{2}$. Neste momento fui obrigada a me dar conta de diversos aspectos relativos à sua obra e do fato de que deveria encontrar critérios bem específicos para efetuar a notação musical, dada a diversidade de situações encontradas. Se pretendesse obter uma partitura clara e objetiva deveria selecionar os acontecimentos musicais que julgasse mais relevantes, como se fossem um desenho estilizado de sua música. Se tudo o que ocorria nas gravações viesse a ser anotado, ao invés de fidelidade estaria engessando a possibilidade de interpretação de quem fosse utilizar o material com esse fim. Esse impasse deixou claro outro aspecto: a partitura era um espaço muito restrito para conter todos os eventos, pois não se tratava apenas de notas musicais sendo combinadas com poesia, era uma obra calcada no momento da atuação, na performance, pressupondo "ouvidos atentos", presentes e atuantes. Querer fazer caber tudo num lugar só não seria possível.

O intento desse estudo presente é o de identificar alguns dos processos de composição adotados por Itamar Assumpção relacionando-os a sua vivência musical, a sua formação. As partituras, previamente transcritas se tornaram um dos materiais de apoio, tendo sido provenientes de minha própria escuta. Tratei também de reescutar as músicas tendo em mãos as transcrições. Uma escuta atenta, mas um pouco mais distanciada, e mediada, para ter a possibilidade de associá-la à memória do conteúdo proveniente dos

\footnotetext{
${ }^{2}$ Em 2006 foi lançado o song book Pretobrás - porque que eu não pensei nisso antes - o livro de canções e histórias de Itamar Assumpção (2006). São Paulo, Ediouro.
} 
depoimentos colhidos de algumas pessoas próximas a ltamar, de suas próprias falas (em entrevistas e em conversas comigo), dos vídeos, da minha vivência como contrabaixista ensaiando, gravando e tocando em seus shows, e dos textos de apoio.

\section{Criação e performance: estabelecimento de matrizes composicionais.}

Quando se observa os trabalhos dos artistas que desenvolvem sua ação apoiados na performance podemos verificar o quão facilitadora torna-se a "leitura" de sua obra quando se leva em conta o efeito e o impacto que ela gera sobre pessoas, sem basear a busca apenas nos registros ou nos resíduos materiais. Isso porque a performance lida com o momento presente e com a interação, mesmo que silenciosa do público, daqueles que são testemunhas e que acabam tornando-se coautores da situação ou ambientação específicas que ela estabelece. Os processos criativos sob os quais esses trabalhos são gerados não são tão explícitos quanto aqueles que geram uma pintura, por exemplo. A materialidade de um quadro pode ser observada com detalhes e, dessa observação, deduzida a técnica empregada. Assim, parte da curiosidade é satisfeita. "Parte" porque talvez os processos criativos não possam ser desvendados de maneira categórica, mesmo nos casos onde um objeto material tenha sido constituído para ser observado ou tocado com status de arte. A performance muitas vezes congrega elementos de diversas áreas de expressão artística e possui a singularidade de se constituir e de se fazer no momento presente, perante a presença e o momento de um outro alguém, muito embora também não prescinda da técnica.

Itamar Assumpção é um desses artistas, calcados na performance. Compositor, instrumentista, arranjador, cantor e ator. Parte de sua obra pode ser constatada nos seus 12 discos, nos diversos registros em vídeo ${ }^{3}$, e através das partituras de seu song book, transcrições da maioria de suas canções. No entanto, deixar de averiguar a performatividade de Itamar provoca um hiato entre as características que supostamente são constituintes de seu estilo de composição e a possibilidade de enxergar sua obra de maneira mais ampla.

\footnotetext{
${ }^{3}$ Parte deles agrupados no recente documentário "Daquele instante em diante" (2011), com direção de Rogério Veloso
} 
Tudo parece fazer mais sentido quando se leva em conta seu modo de atuação, suas escolhas em relação à forma de manifestar a obra. A composição está impregnada do exercício teatral da encenação e da representação, e vice-versa, a atuação é movida pela musicalidade. Era evidente que suas composições, suas canções, se amplificavam como acontecimento no palco, durante os shows. Sua presença física, reforçada pela vivência como ator ${ }^{4}$, era muito carismática e impactava a plateia. Esse impacto se dava justamente devido ao fato de conseguir trazer o espetáculo para o tempo presente (o "não tempo", que é o tempo do ritual), e de conseguir estabelecer com clareza um espaço cênico, multiplicando os sentidos das canções através de sua voz, de seu gestual, da composição de sua figura (com uso de adereços, roupas e óculos escuros). Além desse aspecto, prosseguindo sob a intenção de investigar a obra do autor, é possível destacar a presença da voz como desencadeadora e geradora em seus processos criativos. Não somente a voz atrelada ao texto, como é típico na canção, mas o fato de que a voz, quando escutada, por si só pressupõe a presença e a corporalidade de alguém ${ }^{5}$, e que, portanto possui funções anteriores e maiores do que as da fala.

Estipulamos também, para o estudo, possíveis matrizes de composição. São recursos que o compositor utiliza de maneira sistemática, mas que não precisam ser entendidos como linhas estanques de procedimento, que possuam materiais musicais distintos. Trata-se apenas de um recurso de abordagem que, a nosso ver, clareou a reflexão acerca das características principais da obra, a fim de poder apresentá-los. A maneira de se compor música, em geral, quer estejamos nos referindo à música popular ou de à concerto, é bastante diversa. E os estudos que se dedicam a destrinchar esses procedimentos são feitos posteriormente, naturalmente. Acabam, como um dos resultados, por definir as técnicas empregadas, fato que não necessariamente corresponde ao intuito dos compositores. Ou seja, um estudo como este não é capaz de deixar claro se o compositor empregou os elementos detectados em

\footnotetext{
${ }^{4}$ Itamar participou do grupo de teatro GRUTA (Grupo de Teatro de Arapongas) quando morou no Paraná. Em 1971 fez o papel de Tiradentes na peça Arena conta Tiradentes, de Augusto Boal e Gianfrancesco Guarnieri.

${ }^{5}$ Conforme aponta Paul Zumthor (2000).
} 
suas composições de maneira plenamente consciente ou não, e se sua recorrência é proposital ou casual. Isso não quer dizer que não haja técnicas disponíveis e utilizadas, significa apenas que os impulsos para a criação estão mais ligados à espontaneidade, e que respondem primeiramente às necessidades diversas de expressão. 


\section{CAPÍTULO 1 - CONSTRUÇÃO DA POETICIDADE MUSICAL E ARTÍSTICA NA OBRA DE ITAMAR ASSUMPÇÃO}

"Entre o sim e o não existe um vão"

Itamar Assumpção

\section{Biografia às avessas}

Ao invés de uma biografia que descrevesse detalhes cronológicos da vida de Itamar Assumpção optamos por procurar traços importantes em situações vividas por ele que tivessem relação com sua formação musical. Há vários trabalhos acadêmicos recentes, enfocando tanto a Vanguarda Paulista (da qual Itamar foi participante) sob o aspecto da identidade comum dos grupos integrantes e da performance, como também enfatizando a obra do compositor. Neles está contextualizada, de certa forma, a importância de Itamar face à genealogia da Música Popular Brasileira e seu possível papel dentro da Vanguarda Paulista. Serão citados no decorrer do texto. Constam nesses escritos, além da pesquisa sobre a obra, um pouco de sua biografia pessoal e cronológica.

Naturalmente, é preciso que se nomeie, situe e identifique o objeto de estudo. No entanto o aparato bibliográfico não é capaz de explicar o porquê das decisões ou dos processos criativos terem sido tomados e acionados pelo artista ou autor ${ }^{6}$. Nem cabe aqui a tentativa de explicar a gênese dos processos criativos na arte. É um assunto bastante interessante, mas predominantemente da competência da neurociência, musicoterapia, sociologia, etnomusicologia e psicologia, áreas do conhecimento que detêm

\footnotetext{
${ }^{6}$ Pierre Bourdieu discute essa questão no artigo $A$ ilusão biográfica do livro Usos e Abusos da História Oral, de como as biografias, em geral, tentam dar linearidade e coerência à vida e à identidade das pessoas biografadas. Como se, ao sequenciar os fatos, fosse possível descobrir uma lógica e uma causalidade que levassem à uma explicação conclusiva sobres os motivos pelos quais uma obra ou um autor assumem determinadas características. "[...] cabe supor que o relato autobiográfico se baseia sempre, ou pelo menos em parte, na preocupação de dar sentido, de tornar razoável, de extrair uma lógica ao mesmo tempo retrospectiva e prospectiva, uma consistência e uma constância, estabelecendo relações inteligíveis, como a do efeito à causa eficiente ou final, entre os estados sucessivos, assim constituídos em etapas de um desenvolvimento necessário." (BOURDIEU in FIGUEIREDO, FERREIRA: 2006, p.184)
} 
ferramentas mais apropriadas para realizar aferições desse tipo. Podemos supor também que a formação nunca se encerra, e que a formação musical faz parte da formação artística e pessoal.

$\mathrm{Na}$ medida em que foram tomados os depoimentos, compiladas as entrevistas e declarações, fui percebendo um pouco dessa imprecisão nas datas e na sequência dos acontecimentos, demonstrando que a memória tende a não ser linear e está bastante sujeita ao filtro da interpretação. A memória pode ser repleta de sensações e emoções, e os fatos não aparecem necessariamente concatenados segundo uma "linha" temporal. Mais do que tomar esses desencontros como erros, procurei situações que pudessem convergir.

No caso de Itamar há ainda uma questão a mais, que é o fato dele não ter tido formação acadêmica. A aprendizagem de música ocorreu através da escuta, da vivência e da experimentação em determinados contextos, casuais e intencionais. Casualidade no sentido de serem situações ou lugares onde teve que estar sem necessariamente haver escolhido estar - (como os batuques de Tietê e a Umbanda) e intencionalidade nas situações onde ele, já imbuído de um sentido artístico, escolhia por afinidade as informações e as pessoas com quem compartilhar (como o GRUTA - Grupo de Teatro Universitário de Arapongas - e a "república" onde morou com Arrigo e Paulo Barnabé).

Por esse motivo também se torna igualmente difícil supor com certeza quais acontecimentos teriam sido de fato decisivos para que ele realizasse a série de sínteses que definiram as características de sua obra. A formação musical fora de escolas formais é bastante comum aos autores brasileiros de canção, na música popular urbana, em autores nascidos até a metade do século XX, e ainda hoje. Aliás, essa seria uma das prerrogativas para definição de música popular, o fato de não se aprendê-la em uma instituição de ensino. Portanto essa não seria uma característica exclusiva de Itamar. Mas se de fato há uma história a ser contada, os caminhos e direções são abertos por alguns desbravadores. Esse conhecimento se aloja e se desenvolve na oralidade e na 
capacidade de apropriação e ressignificação que os artistas atribuem ao material musical.

Sei que meu método de aprendizado foi muito estranho, porque comecei a fazer isso sozinho, sem nenhuma noção, nenhuma orientação. Minha mãe tinha um rádio portátil, daqueles que tinham uma antena e funcionavam com oito pilhas, deste tamanho. Eu saia de manhã e só voltava à noite com aquele rádio a todo volume pela rua. (ASSUMPÇÃO apud PALUMBO: 2002, p.29).

Como veremos a seguir, esse veio de extrair as informações musicais que almejava através da escuta o acompanhou sempre, desde as primeiras experiências como músico: cantar, tocar, compor e arranjar.

Justamente por isso, voltando à questão da biografia, partimos do caminho inverso, buscando primeiro as informações na música e depois aferindo junto aos acontecimentos (descritos nas biografias, entrevistas e cronologias) alguns tipos possíveis de conexões e afinidades. Proximidades essas que não pretendem, conforme já foi dito, servir como prova ou explicação para a natureza dos processos criativos empregados, mas sim apontar para a capacidade que Itamar tinha de reelaborar materiais musicais de uma maneira muito própria integrando-os ao forte conteúdo poético (no sentido literário e artístico) que possuía e à performance musical e teatral criada em seus shows ${ }^{7}$.

Sendo assim, já que aqui não nos preocupamos em desenhar exatamente uma linha do tempo, não foram feitas referências a todos os acontecimentos de vida que estão documentados, mas somente àqueles poucos que julgamos relacionarem-se diretamente com a prática musical. Assumimos e consideramos aqui que Itamar é um desses compositoresdesbravadores da Música Popular Brasileira e que efetivou claramente uma ruptura de linguagem, como pretendemos demonstrar adiante. O compositor Arrigo Barnabé reitera, em entrevista (que também será citada ao longo do trabalho) o que disse no texto do encarte do disco Pretobrás I (o último a ser finalizado por Itamar em vida) sobre essa característica de transfiguração e recriação.

\footnotetext{
7 São extremamente úteis os conceitos, reflexões e questões relacionadas à performance sugeridas por Paul Zumthor (ZUMTHOR: 2000 e 2005) que aqui serão aplicadas à obra de Itamar.
} 
Ouvir Pretobrás foi provocando e mim uma sensação quase de um filme. E nesse filme eu via um quintal de terra no interior do Paraná, um quintal de casa de madeira, um quintal de chão de terra, com suas peculiaridades, os seus matos e criações, os seus utensílios. $O$ meu olhar câmera perseguia alguma coisa nessa paisagem, o âmago da sensação causada pela música. Então vi, do lado do tanque de lavar roupa, a lata de óleo de cozinha transformada em vaso de flores. Era essa imagem que eu procurava. $\mathrm{O}$ uso da embalagem industrial desvinculada do seu sentido de mercadoria. Hoje, quando a embalagem mostra-se como o grande trunfo da indústria musical, Itamar transforma latas vazias em vasos de flores. Ele utiliza as embalagens abandonadas para criar um trabalho de uma originalidade extrema (extrema por não evidente) sem nunca adaptar-se ao "gosto" indicado pela indústria. (BARNABÉ: 1998, texto do encarte do CD PRETOBRÁS I)

O próprio Itamar, em entrevista à jornalista Patrícia Palumbo para o livro Vozes do Brasil, considera que sua obra apresenta resultados sofisticados para quem nunca estudou música formalmente. "O meu trabalho tem condições de ser analisado. Acho que o novo é isso” (ASSUMPÇÃO apud PALUMBO: 2002, p.34)

\subsection{OS BATUQUES DE UMBIGADA DE TIETÊ - A RÍTMICA NA OBRA DE ITAMAR ASSUMPÇÃO}

A cidade de Tietê era, onde nasceu Itamar em 1949, além de Capivari, Piracicaba, Laranjal e Porto Feliz, um local típico onde os festejos de batuque de umbigada (ou de tambú ${ }^{8}$ ) se realizavam na comunidade negra, criados por descendentes de ex-escravos da etnia bantu (de Angola e do Congo, que haviam vindo como escravos para o Brasil). As modas ${ }^{9}$ eram (e ainda são) cantadas em terças, e acompanhadas por quatro tipos de instrumentos de percussão: o tambú, o quinjengue, a matraca e o guaiá, serão descritos adiante. A dança também é muito característica, pois os pares intercalam os improvisos de movimento e de passos com a umbigada.

As temáticas abarcam questões cotidianas referindo-se a fatos da vida, à questões existenciais e aos acontecimentos do dia a dia. Questões raciais ligadas aos conflitos e às sequelas sociais referentes ao período de escravidão

\footnotetext{
${ }^{8}$ Nome do tambor principal do Batuque de Umbigada, feito de tora de madeira e couro. Segundo depoimento do documentário No repique do tambú, realizado pelos pesquisadores do Espaço Cultural Cachuêra em 2003, há tambores de mais de cem anos sendo utilizados ainda hoje. Esse documentário serviu de referência para as colocações aqui feitas.

${ }^{9}$ Tal como se denominam as modas de viola.
} 
eram muito evidentes na década de 40 . As letras de parte significativa das modas falava (e ainda continuam sendo cantadas) sobre o assunto, segundo 0 músico e pesquisador Paulo Dias (que realiza trabalhos de registro de áudio e vídeo na região há mais de 15 anos). Há referências ao dia 13 de maio e à princesa Isabel que "assinou um papé" ${ }^{10}$, libertando os escravos em 1888. Os batuques ocorrem ainda hoje (conforme mostra o documentário No Repique do Tambú $^{11}$ ), em Tietê, juntando as comunidades das cidades vizinhas, em meados do mês de setembro, época de comemoração a São Benedito.

As festas, nesses anos onde Itamar era criança em Tietê, eram aceitas com restrições pelas autoridades representativas das classes dominantes brancas. Muitas vezes para que se realizasse o batuque dentro da cidade ou em local muito próximo ao centro era necessário ter autorização da polícia. E especialmente na cidade de Tietê, ainda segundo o músico Paulo Dias, surpreendentemente se faz perdurar até hoje essa espécie de "apartheid", configurando situações constrangedoras aos negros, tais como ruas ou locais onde não se costuma circular e restaurantes onde não se pode entrar, num acordo tácito, mas nem por isso aceito de fato. Itamar fazia referência a situações ocorridas também nos clubes de música, onde quando garoto, segundo Elizena Brigo de Assumpção, sua esposa, tinha que assistir aos bailes do lado de fora, através da janela do local onde ocorriam (por ser menor de idade e por ser negro). E ao mesmo tempo, segundo Denise Assunção ${ }^{12}$, Itamar escapava de casa para assistir aos Batuques, que em princípio eram feitos por e para adultos (sobretudo se levarmos em conta o período de referência, o dos anos da década de 1950).

Itamar permaneceu na cidade de Tietê até os 13 anos, quando morreu sua avó materna. Ele e o irmão Narciso, que haviam sido criados até então

\footnotetext{
${ }^{10}$ A letra de "Batuque" de Itamar Assumpção, gravada ao vivo no disco Às próprias Custas S.A. termina com essa corruptela da fala, fazendo parecer que é um escravo liberto quem diz. Em seguida a performance de Itamar segue, ele faz com a boca e a voz o som do papel (este mesmo que foi assinado) sendo amassado. Uma ironia, afinal é só um papel, e ainda completa: "deixa pra lá... eu tô aqui pra outra coisa." (CD anexo faixa 1)

${ }^{11} 2003$, realizado pelo Espaço Cultural Cachuêra, dirigido pelo pesquisador Paulo Dias.

${ }^{12} \mathrm{O}$ sobrenome da atriz e cantora, irmã de Itamar, foi grafado diferente junto ao cartório por seu próprio pai Januário, conforme conta em sua autobiografia intitulada "Ela" (impressa por conta própria, sem editora). Os dois irmãos Narciso e Itamar tinham o mesmo sobrenome Assumpção.
} 
pelos avós, mudaram-se para Arapongas (cidade do estado do Paraná) para junto dos pais (Cida e Januário) e da irmã Denise depois disso. "Em casa, a minha avó era a matriarca, como nas tribos africanas em que a mulher é quem manda. Minha avó lutava, e meu avô era alfaiate. Ela cuidava de tudo, da gente do galinheiro, da horta. Aprendi tudo com ela", diz Itamar na entrevista à Palumbo (ASSUMPÇÃO apud PALUMBO: 2002, p.30).

Aparentemente não há nas canções de Itamar uma preocupação que foque predominantemente questões sociais ou políticas. Quando aparecem são tratadas como pano de fundo para sua construção e visão poéticas. Sua intenção não se restringia a querer transmitir um conceito específico. A poeta Alice Ruiz, parceira de Itamar em dezenas de músicas, fala em entrevista (que consta dos anexos) de uma das características de Itamar enquanto letrista: "Era alguém que tinha o que dizer. [...] Mesmo aquelas poesias que parecem mais banais, corriqueiras e falando do cotidiano, estão carregadas de significados, carregadas de substância".

Parece então que Itamar procurava transcender essas questões, pelo menos dentro da obra, embora sempre fosse questionado a respeito. Pessoalmente viveu situações explícitas de racismo ${ }^{13}$. Há palavras e temáticas que resvalam nesses fatos em alguns momentos pontuais. Referências sutis à cultura negra, à negritude em si, à escravidão, às raízes das religiões afrobrasileiras, às diferenças sociais, mas aparecendo sem conterem algum teor reivindicatório. As músicas Batuque, Lambuzada de Dendê, Quem é Cover de Quem, Cabelo Duro ou o fato de citar São Benedito na música Santo de Casa podem ser exemplos.

\footnotetext{
13 Tais como a prisão pelo suposto roubo de um gravador. Domingos Pellegrini, amigo de Itamar e parceiro de letra na canção "Prezadíssimos Ouvintes", emprestou um gravador a Itamar. A policia o prendeu porque acreditou que ele o havia roubado. O episódio é contado por Pellegrini em texto do Vol. 2 do song book (p.19), e pelo próprio Itamar em entrevista à P.Palumbo (p.31) Domingos sugere o fato de que o nome Isca de Polícia possa ter surgido dessa situação. Sendo ou não o mote para ideia do nome, ainda assim Itamar demonstra bom humor (exercido com inteligência), apesar da situação constrangedora pela qual passou. Durante os anos 70 , devido à ditadura militar e os ecos da contracultura um negro carregando um gravador pela rua não passava despercebido. Outra situação (descrita por Itamar em uma das conversas que tivemos) foi a abordagem de um policial no momento em que ele corria pela rua para alcançar a esposa para entregar the o cartão de banco que havia esquecido de apanhar. O policial interpretou a ação como sendo algum tipo de assédio ou tentativa de assalto, uma vez que sua esposa é branca.
} 
De qualquer maneira, há em suas composições e em sua atuação no palco uma série de recorrências que muito se aproximam dessa festa celebração do Batuque de Umbigada, onde as canções ocorrem como uma espécie de crônica do cotidiano das pessoas da comunidade que o formam. Cada qual pode encontrar um paralelo entre 0 ritual ${ }^{14}$ do batuque e sua vivência pessoal, tornando explícitas questões que dizem respeito à própria condição social e que normalmente não pode ser discutido em outros ambientes, o das outras classes sociais.

\section{a) A voz como propulsora do processo criativo}

Ocorre uma semelhança especialmente interessante entre a instrumentação presente nos Batuques de Umbigada $^{15}$ e aquela que Itamar utiliza em suas próprias composições e arranjos. Nos Batuques o tambor grave (o tambu) é aquele que "conversa" e que improvisa ${ }^{16}$. Os instrumentos agudos mantêm a condução enquanto o grave é quem fala e dialoga, "argumenta". $\mathrm{Na}$ música de Itamar esse papel é desempenhado pelo contrabaixo (instrumento de tessitura grave). É ele quem se contrapõe à melodia e às palavras dos poemas que são veiculados. Tanto é assim que algumas de suas canções podem ser executadas, sem haver comprometimento da inteligibilidade, somente com a entoação da melodia em contraponto com a linha de baixo. Portanto, quando Itamar opta por sons graves, desenha uma faixa de frequência que estará sempre presente, uma tessitura, como se fosse uma voz dizendo algo além das palavras.

Há na voz uma espécie de indiferença relativa à palavra: no canto, por exemplo, chega-se a certos momentos em que a voz somente modula sons desprovidos de existência linguística: "tra-la-lá", ou alguns puros vocalizes. Existem formas de canto cuja particularidade, é ausência da língua, ou pelo

\footnotetext{
${ }^{14}$ Há algumas definições a respeito do que significa ritual, expressas por Paul Zumthor, e que adotaremos mais adiante juntamente com definições de performance, de poeticidade e do uso da voz, imprescindíveis no caso de Itamar.

${ }^{15}$ Também presentes no jongo, no tambor de criola e no candomblé.

${ }^{16}$ A musicista, percussionista e compositora Simone Sou, que também tocou com Itamar, destacou esse fato em conversa informal comigo, refletindo sobre as características que poderiam se destacadas no Batuque de Umbigada.
} 
menos uma certa tendência da voz a dissociar os elementos da linguagem que ela transmite. O que importa mais profundamente à voz é que a palavra da qual ela é veículo se enuncie como uma lembrança; que esta palavra, enquanto traz um sentido, na materialidade das palavras e das frases, evoque (talvez muito confusamente) no inconsciente daquele que a escuta um contato inicial, que se produziu na aurora de toda vida, cuja marca se apagou em nós, mas que, assim reanimada, constitui a figura de uma promessa para além não sei de que fissura. (ZUMTHOR: 2005. p.64).

As construções melódicas, muitas vezes sem grandes saltos intervalares e com repetições de notas, também estão impregnadas da expressão rítmica advinda dos tambores. Este aparenta ser um dos seus principais recursos de composição, fato em si que já demonstra uma das peculiaridades da obra ${ }^{17}$. Ao justificar à Patrícia Palumbo, durante a entrevista, o porquê da escolha do contrabaixo como instrumento sempre presente em sua música Itamar fala:

O contrabaixo é o mais percussivo dos instrumentos de cordas. É um instrumento percussivo que dá nota, e o que me pega é a possibilidade do ritmo, porque o meu negócio é o ritmo. O contrabaixo me deu uma possibilidade maior de frases. Às vezes nem componho no violão.[...] componho para o contrabaixo. Assim não há harmonia, acorde, são só notas. (ASSUMPÇÃO apud PALUMBO: 2002, p.34).

Teríamos então duas questões importantes para serem levadas em conta na abordagem das características das composições de Itamar Assumpção. Estão elas nos papéis desempenhados pelo uso da voz. Primeiro o fato de que podemos considerar o contrabaixo como sendo ele mesmo uma "voz", de suma relevância. Conforme expressou o próprio compositor, trata-se um elemento capaz de servir como veículo de expressão e de efetivação daquilo que quis constituir musicalmente e artisticamente. E segundo, a utilização da voz cantada não só como elemento de propagação do texto, mas também como expressão com poder de agregar performatividade, e por consequência de ampliar as significações. Em estudo sobre a performatividade da voz e sua ligação com os processos de criação a pesquisadora Wânia Mara Agostini Storolli descreve e reflete sobre a proximidade que há entre a criação artística e as pesquisas sobre o uso da voz. Constata a mudança drástica de critérios estéticos, ocorridas durante o século XX, que alteraram o padrão do Bel Canto,

\footnotetext{
${ }^{17} \mathrm{Na}$ canção popular urbana, quando há acompanhamento este se dá predominantemente de maneira vertical, através da harmonia, e não contrapontisticamente.
} 
incorporando outros tipos de sons como "gritos, sussurros, gemidos, sons guturais, assovios, estalos de língua" (STOROLLI: 2011, p.1,) ${ }^{18}$ e convergindo com as investigações sobre o corpo no âmbito do fazer artístico. Storolli aponta como artistas $^{19}$ efetivaram determinadas produções artísticas através da percepção de que a voz possuiria uma "linguagem em si mesma":

\begin{abstract}
A voz percebida em sua relação com o corpo é o centro de muitas experimentações, revelando-se para alguns artistas como elemento propulsor de seus processos de criação. É através do processo de investigação das possibilidades da voz que alguns artistas conseguem firmar-se como artistas criadores e desenvolver linguagens artísticas singulares. No contexto da experimentação a ação vocal passa a incorporar toda e qualquer possibilidade de emissão, deixando de se organizar a partir de critérios estéticos pré-definidos. A voz revela-se então como som, como uma linguagem em si mesma. (STOROLLI: 2011, p.1.)
\end{abstract}

Embora se referindo aos artistas em geral, essa parece ser uma abordagem pertinente à obra de Itamar, conforme também aponta Regina Machado, mencionando os artistas da Vanguarda Paulista, da qual Itamar fazia parte, no livro $A$ voz na Canção Popular Brasileira - um estudo sobre a vanguarda paulista. Verificaremos como muito da ação performativa de Itamar, nas composições, gravações e atuações ao vivo, estão relacionadas ao uso consciente da voz, trazendo-lhe a dimensão cênica associada a outros elementos artísticos.

\title{
b) A cena para o desenrolar da música.
}

Sobre sua atuação cênica durante os shows também há semelhanças com um dos procedimentos que ocorrem nos batuques, o desafio ${ }^{20}$. 0 "embate" nos batuques se dá entre as modas que vão sendo cantadas (ou "puxadas"), em sua alternância. Alice Ruiz lembra ${ }^{21}$ dessa característica, nas performances dos shows ao vivo de Itamar, de sempre haver na plateia alguém a quem Itamar se dirigia por ter sido indagado ou por ter dito alguma coisa em

18 XXI Congresso da Associação Nacional de Pesquisa e Pós-Graduação em MúsicaUberlândia-2011, Performatividade da voz e processos de criação. Wânia Mara Agostini Storolli.

${ }^{19} \mathrm{Tal}$ como Meridith Monk e Fátima Miranda.

${ }^{20}$ Os desafios estão presentes em diversos gêneros da música popular, como o repente, o coco de embolada, e também o cururu (típico da região) não sendo exclusividade dos batuques de umbigada.

${ }^{21} \mathrm{Em}$ texto do songbook, (RUIZ, apud ASSUMPÇÃO: 2006, Vol.I, p.57) 
voz alta, aparentemente interrompendo-o. Estabelecia-se ali um conflito utilizado propositalmente, de maneira cênica, por Itamar para responder com falas que amarravam o espetáculo, e que justificavam e anunciavam a entrada da próxima música. Como Alice observa, haveria aí um contrassenso, marcado por um traço de humor. Quando Itamar resolvia questionar alguém do público por encará-lo ou por dizer algo, abria-se um parêntese no espetáculo, que confundia a plateia ao instaurar a dúvida sobre se ele estaria mesmo, de fato, bravo. O público está ali para observar, escutar e ver (embora saibamos, com um papel ativo), e se o espetáculo o convida intensamente a se envolver, criase uma situação de estranhamento, quando esse envolvimento é questionado.

Esses desafios são percebidos também nas estruturas internas das composições. Quase sempre estão presentes vocais, com vozes femininas em coro ou abrindo vozes. Essas vozes o interpelam, o questionam, gerando um diálogo que move o discurso e interferem em seu resultado. $O$ desafio está também na utilização de discursos ou textos jurídicos (gênero que tinha apreço) em algumas canções, tal como Denúncia dos Santos Silva Belelé $u^{22}$, ou Estropício. Vera Motta, advogada e parceira de Itamar em algumas composições lembra ${ }^{23}$ : "Itamar gostava da linguagem jurídica, nela via um tipo de poesia e ritmo".

É dela a voz da gravação que antecede a canção Estropício em que é lida uma requisição de separação de corpos. E mais uma vez aqui a utilização sutil do humor. A leitura desse texto técnico intermedia os fortes sentimentos, entre o denunciante e a réu, e até os incorpora na escolha das palavras, mas aparenta apatia e distanciamento diante da situação de atrito, pela maneira como é lido (sem alteração na entonação da voz) e por conter dados "fictícios" ${ }^{24}$, sem nexo.

\footnotetext{
${ }^{22}$ Música "defendida" no festival MPB Shell, da TV Globo, em 1982, dado que consta no texto de Maria Betânia Amoroso no Song Book (AMOROSO: 2006, Vol.I, p.49).

${ }^{23} \mathrm{Em}$ depoimento para o songbook, (MOTTA apud ASSUMPÇÃO: 2006, Vol.2, p.51)

${ }^{24}$ Tais como "a rua que sobe e nunca desce", "portanto o $n^{\circ}$, por favor, vê se esquece" e etc.
} 


\section{c) Células aditivas}

No programa televisivo Ensaio da TV Cultura de São Paulo, gravado e exibido em 1999, Itamar, respondendo a uma pergunta de Fernando Faro cantarola o ritmo dos Batuques, fato que demonstra a consciência e a memória que tinha das sonoridades que o haviam cercado ${ }^{25}$ antes de se tornar músico e compositor.

As células rítmicas dos batuques de umbigada, transcritas aqui, extraídas do documentário No repique do tambú, são:

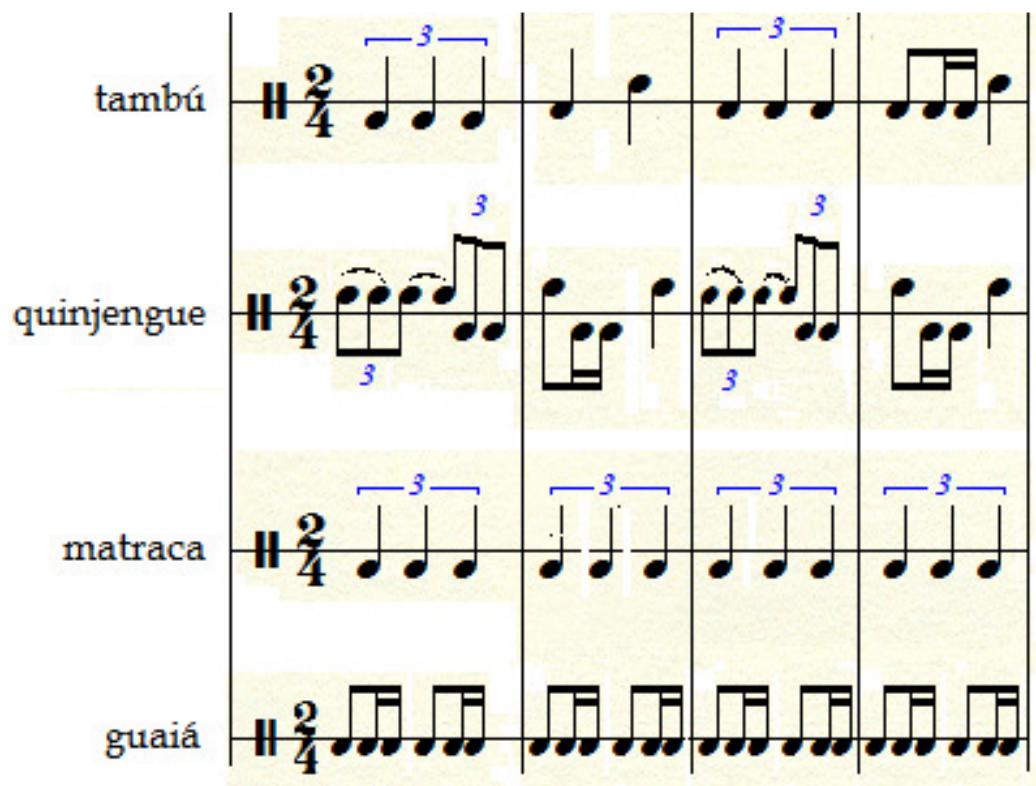

Fig. 1: batuque de umbigada, células rítmicas.

Tambú é um tambor grave. Ao mesmo tempo em que faz as marcações (do momento em que ocorre a umbigada inclusive) é também o instrumento que improvisa, e que comenta. Feito de tronco de árvore esculpido, o tocador senta-se sobre ele. Os batuqueiros se referem a esse tambor como um

${ }^{25}$ É possível fazer referência ao conceito de Paisagem Sonora criado por R. Murray Schafer. Sendo assim, o compositor não manifestaria a "lembrança" da sonoridade do batuque como se fosse necessariamente um componente de sua música e sim como uma "atmosfera" à qual acabou sendo submetido e que pode ter contribuído junto com outras diversas vivências em seu modo de ouvir os sons e de organiza-los para compor. 
instrumento que tem que ser domado, sendo que o emprego da leveza, e não da força, é que resulta em produção de mais som ${ }^{26}$.

Quinjengue (ou mulemba) é também um tambor, menor e com som agudo. Ele preenche, tanto na tessitura como no fraseado, os espaços deixados pelo tambú. Ele é posicionado verticalmente.

Matraca. São baquetas de madeira, feitas de pedaços de pau, que percutem o corpo do tambú. Como o tambú é extenso e posicionado horizontalmente, no chão, é possível que um outro músico possa tocá-lo simultaneamente produzindo um som agudo. Não há variação na linha e ela se presta à marcação também, suprindo a condução quando os outros sons variam.

Guaiá é um chocalho feito de metal, e que pode ser utilizado por quem canta as modas e por quem dança.

Verificaremos como as composições de Itamar possuem forte influência desse veio de expressão, tanto pela utilização de elementos musicais semelhantes aos que acabamos de descrever como pela ancestralidade inerente que possuem com a música africana, antes mesmo de terem sido desenvolvido no Brasil. Itamar utiliza diversas vezes figuras rítmicas tercinadas sobrepostas a figuras binárias em momentos específicos de arranjo, lembrando muito o que ocorre nos batuques.

Carlos Sandroni, autor do livro Feitiço Decente ${ }^{27}$, fez uma compilação das pesquisas sobre a polirritmia africana e refletiu sobre sua presença na música brasileira, especialmente no samba. $O$ intuito de sua pesquisa foi demonstrar a quebra de paradigma em relação à maneira de se tocar samba a partir de 1917. Aqui, no entanto, a reflexão presente em seu estudo nos apoia indiretamente quando trata de apontar aspectos específicos da presença musical da tradição africana no Brasil, à qual Itamar está evidentemente ligado, quer seja pela ascendência biológica direta dos bantus, quer seja pela

${ }^{26}$ Esse pensamento me faz lembrar uma das principais maneiras de Itamar conceber a sonoridade nas execuções ao vivo: a utilização de nuances de dinâmica, predominantemente optando por tocar leve e manter o volume de som baixo, a fim de trazer e prender a atenção dos ouvintes para o espetáculo e de manter espaço para a percepção sobre sutilezas musicais. ${ }^{27}$ Esse estudo explica de maneira aprofundada as questões que tomamos como referência aqui. (SANDRONI, Carlos. Feitiço Decente. Jorge Zahar Editora, 2000) 
experiência de escuta, absorvendo uma referência sonora. Essa presença ajudou a desenhar em nosso país, junto com a música indígena e europeia, não somente o samba (que proliferou como música popular urbana), mas a diversidade dos gêneros brasileiros ${ }^{28}$ que constituem a música brasileira.

A música de Itamar não se coloca como classificável em termo desses gêneros. A ocorrência do samba é muitas vezes implícita (embora haja alguns sambas compostos ${ }^{29}$ ). Tampouco é frequente a presença da sincopa, conceito geralmente associado à música popular brasileira. $\mathrm{O}$ samba pode ser visto nas entrelinhas das composições, como referência, na escolha, por exemplo, da gravação temática do disco Ataulfo para sempre agora. Na regravação das composições de Ataulfo Alves não aparecem os sambas originais, e sim 0 revestimento dado pelo arranjo que Itamar detalhadamente deu às canções, sem obscurecê-las. Na música de Itamar cada canção "é uma coisa, uma história” ${ }^{30}$, fato que a simples escuta da obra pode comprovar.

Mas a pesquisa de Sandroni aponta um aspecto que nos interessa aqui. Ao reforçar o que já havia sido constatado ${ }^{31}$, de que a maneira ocidental de tentar grafar a música africana (através de compassos) é inadequada, quando se quer compreender algumas de suas sutilezas, deixa clara uma questão importantes para nosso estudo. O fato de que a nomenclatura "síncopa", ao ser criada para explicar um fenômeno musical, acaba ocultando uma importante diferença de princípio entre a música clássica ocidental e a música popular africana oriental. A diferença de que, no fundo, essas estruturas musicais são forçadamente encaixadas dentro dos compassos, nos quais de fato não são cabíveis. Como lembra Sandroni, o compasso é uma invenção tardia, ocorrida na Europa a partir do Barroco (SANDRONI: 2000, p.20). E o conceito de sincopa está diretamente ligado à ideia de compasso porque as definições teóricas (que constam em dicionários de música ${ }^{32}$ ) a colocam como sendo o momento em que a melodia (ou segmento) contrasta com a métrica subjacente, "escapando"

\footnotetext{
${ }^{28} \mathrm{~A}$ maneira coloquial de se referir à diversidade de gêneros da música popular brasileira elege a palavra ritmo como sinônimo de samba, maxixe, maracatu, forró, xote, xaxado, ciranda, baião, frevo, catira, chorinho, e etc., e as dezenas de práticas composicionais, tradicionais ou não, realizadas no Brasil em música popular.

${ }^{29}$ Maremoto e Estropício, por exemplo.

${ }^{30}$ ASSUMPÇÃO apud PALUMBO: 2002, p.35.

${ }^{31}$ Apoiado das pesquisas de A. M. Jones, Kazadi-wa Mukuna, Simha Aron.

${ }^{32}$ (SANDRONI: 2000, p.21)
} 
desse agrupamento de pulsos, que se mantêm fixo e regular, e que têm acentuados os primeiros tempos. O equívoco estaria em não se compreender que a música africana parte de um princípio diferente do da música clássica ocidental $^{33}$, o da adição de células rítmicas ao invés do princípio da divisão, e este é o ponto que nos interessa.

Essa característica de adicionar células rítmicas gera assimetrias nas estruturas utilizadas, da seguinte maneira (já que soma unidades distintas, com diferentes durações):

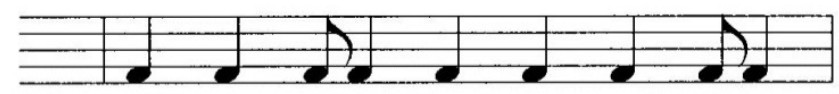

Fig. 2 célula rítmica bantu.

O exemplo da fig.2 mostra uma célula rítmica encontrada frequentemente entre os bantus, destacada por outro pesquisador Kazadi-wa Mukuna (MUKUNA apud SANDRONI: 2000, p.33). Essa frase rítmica, conforme exemplifica Sandroni, não gera subdivisões simétricas, a não ser que sua escrita seja adaptada, encaixada num compasso:

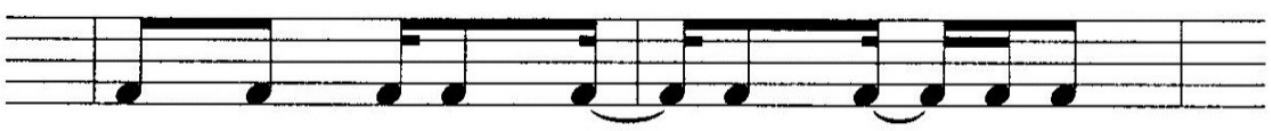

Fig. 3: ritmo do tamborim no samba, semelhante à célula rítmica bantu.

E o resultado é uma célula rítmica bastante familiar à música popular brasileira, que é a tocada pelo tamborim no samba. E por isso a tentativa de grafar, enquadrando-a num compasso e numa métrica regulares, não deixa clara a diferença de princípios. Para os africanos haveria vários fluxos de acontecimentos, que ora são concomitantes, ora tomam caminhos diferentes,

\footnotetext{
${ }^{33}$ Que consagrou as formas atuais de escrita e notação musicais.
} 
já que o elemento norteador ${ }^{34}$ não é o compasso e sim pulso e seus desdobramentos.

Portanto, a característica de adição, herança da música africana, pode ser identificada claramente na música de Itamar, juntamente com a polirritmia, conforme demonstraremos adiante. São traços sutis dessa origem, que poderiam passar despercebidos em suas composições, embora se note claramente que há um trabalho rítmico sendo priorizado. Nas composições de Itamar, devido a possíveis parentescos com esses princípios, podemos identificar o que se chama de polimetria ${ }^{35}$. A escuta nos faz supor que, embora a música ocorrendo em compassos de 4 por 4 , haja agrupamentos assimétricos dos pulsos, através do contraste na utilização de padrões rítmicos distintos e de acentuações, gerando melodias com métricas distintas. Sendo assim a polirritmia e a polimetria seriam conceitos ligados entre si. Ou seja, ao se utilizar a sobreposição de células rítmicas distintas como consequência teríamos a geração de frases com métricas não simultâneas, defasadas, como é o caso da música de ltamar.

\section{d) Arranjo in loco}

$\mathrm{Na}$ experiência prática que tive, tocando como contrabaixista de Itamar, posso destacar duas questões importantes relacionadas a essas colocações

\footnotetext{
${ }^{34}$ Células ímpares $(3+3+2),(3+2+3+2+2),(3+2+2+3+2+2+2)$, conforme descreve Sandroni, estão presentes também no tambor de mina maranhense, no maracatu e cangô pernambucanos, no candomblé, na capoeira de macumba e nos sambas cariocas aparecendo nas palmas, nas batidas de agogôs e nos tamborins.

${ }^{35}$ Conceitos definidos por Turek e Kostka constatando os procedimentos composicionais adotados pela música clássica para burlar os 300 anos da "tirania da barra de compasso" ou "the tyranny of the barline", segundo Turek (Turek: 2006, p.325).Turek define a polirrtimia como sendo a utilização simultânea de padrões rítmicos distintos entre si, e que assim são por adotarem diferentes subdivisões da pulsação. Ele também define a polimetria como sendo a utilização simultânea de tipos de compassos diferentes. (Turek:1996, p.326). Já Kostka especifica três tipos de polimetria (Kostka: 2006, p.120-123): a) segmentos simultâneos que utilizam as mesmas fórmulas de compasso mas com seus inícios defasados; b) segmentos simultâneos que utilizam diferentes fórmulas de compassos mas que possuem a coincidência da barra de compasso; e c) segmentos simultâneas que utilizam diferentes fórmulas de compasso e cujas barras de compasso também não são coincidentes. Não é necessário que aprofundemos a discussão aqui, aferindo se essas classificações cabem ou não na música de Itamar. O fato é que a música deste compositor não nasceu sob a forma da escrita e, portanto, não se pode dizer que ele estivesse tentando criar estratégias composicionais para gerar quebras de compassos ou polirritmias. Parece-nos que esta foi sua maneira natural de combinar os elementos musicais advindos das experiências que teve. Mas o conceito de polimetria é uma ferramenta útil para que, mesmo através da escrita, seja possível refletir sobre aquilo que se ouve.
} 
precedentes, e que eram recorrentes em sua maneira de praticar a música compondo ou ensaiando.

Em primeiro lugar verifico como origem em seu fazer musical a semelhança com o procedimento encontrado na cultura oral ${ }^{36}$ que é por definição iletrada no sentido de não poder ser acessada senão pela mídia primaria $^{37}$ que é o corpo. O conhecimento garante sua perpetuação pela memória e pelo exercício de quem a pratica e a concretiza, e os elementos artísticos se fazem visíveis através da performance. Durante os ensaios ocorriam-Ihe ideias de arranjo, criava frases melódicas e rítmicas que cantarolava (ou eventualmente tocava) e as destinava a cada um dos músicos, cada qual em seu instrumento, até que todos aprendessem. Enquanto uma melodia não se firmasse outra não era acrescentada. Assim um escutava o que era executado pelo outro.

Em segundo, observo que nesse processo de aprendizagem, aonde as frases musicais iam sendo sobrepostas gradualmente, por vezes os músicos passavam a ter dúvidas em relação à qual seria de fato o momento do início ou do fim da melodia (que haviam acabado de aprender) dentro do compasso assim que uma nova frase era acrescentada. Quase todas as composições de Itamar são baseadas em compassos quaternários como já dissemos (com poucas exceções ${ }^{38}$ ). No entanto, na medida em que uma nova frase era criada parecia que o pulso anteriormente compreendido como início do compasso desestruturava a percepção da métrica.

Atribuo essa dificuldade dos músicos (minha inclusive) justamente ao fato de haverem se detido, num primeiro momento de contato com a obra, num modo de escuta condicionado, buscando a simetria e a divisão, ao invés de atentarem ao aspecto da fluidez discursiva ${ }^{39}$ dada pela soma das informações musicais, ou seja pelas células aditivas criadas. Verifica-se que todas essas

\footnotetext{
${ }^{36}$ Cf. ZUMTHOR: 2000,2005.

${ }^{37}$ Conforme Norval Baitello, no texto: O Tempo Lento e o Espaço Nulo - mídia primária, secundária e terciária. Publicado nos cadernos do CISC (Centro Interdisciplinar de Semiótica da Cultura e da Mídia)

${ }^{38} \mathrm{E}$ ainda assim essas exceções se dão apenas pela inserção de um ou outro compasso com outra métrica, no meio de um formato usual quaternário. É o caso de Fon fin fan fin fun, Ausência, Prezadíssimos ouvintes.

${ }^{39}$ No caso da música de Itamar esse aspecto de extravasar os espaços também pode ser notado na poesia, conforme será mostrado nas análises, já que há momentos onde a quantidade de palavras a ser dita não cabe na métrica musical, no número de compassos, gerando soluções inusitadas
} 
frases às quais me refiro podem ser escritas dentro de compassos regulares (como o foram no song book), assim como o ritmo do tamborim descrito anteriormente no livro de Sandroni. Mas no momento em que eram criadas pelo compositor não partiam necessariamente da sincronia e sim da confluência. Cabia aos músicos entenderem a sobreposição de ideias, fato que para Itamar era extremamente natural. Assim, em seu processo criativo, inventava frases que se encaixavam sem haver a predominância de uma sobre a outra, remetendo-se ao fluxo das melodias presente na música africana e oriental onde, muitas vezes, apesar de partirem do silêncio, não há exatamente um início e sim um trajeto sonoro, uma fluência que é capturada num recorte transversal.

A música popular brasileira, urbana ou rural, está impregnada de células rítmicas assimétricas, como demonstra o estudo de Sandroni. No entanto o cuidado aqui está em observar que essas assimetrias se fixaram, se as observarmos sob certo aspecto. Acabaram por caracterizar cada gênero e ajudar a estabelecê-los ${ }^{40}$, na medida em que a instrumentação é sempre mantida igual ou próxima e que cada instrumento tem um papel específico. Ou seja, o maracatu, o coco, o samba, e as dezenas de ritmos brasileiros são reconhecidos como tal, distintos uns dos outros, por terem incorporado, cada qual à sua maneira, essas assimetrias. Fixadas, elas enquadram-se quase sempre, num formato binário ou quaternário gerando uma quadratura geral simétrica. No caso da música de Itamar colocamos a questão de que, além da polirritmia e da síncopa (esta raramente aparecendo), está presente o extravasamento dos compassos através das melodias e das frases tocadas pelos instrumentos, o que geraria polimetrias. Mesmo com o fato de que sua composição pode ser escrita de maneira tradicional, ainda assim podemos verificar as melodias possuindo tamanhos diferentes. Melodias que ocorrem de maneira combinada mas tendendo a perdurar mais ou menos, sem afirmarem com exatidão, para quem ouve o todo, onde é o início e onde é o fim. Como

\footnotetext{
${ }^{40}$ Sem esquecer de todos os elementos que congregam as manifestações populares, tais como o teor da poesia, o modo de cantar, a característica das melodias, a presença da dança e de roupas especiais, seu caráter de comemoração, folia, festejo, sua ligação com a religião e etc.
} 
exemplo dessa aferição, mesmo antes de chegarmos ao capítulo das análises propriamente ditas, cito a canção Sonhei Que Viajava Com Você (fig. 4 abaixo):

1) A melodia portada pela voz possui alguns apoios em notas longas. São elas que quebram a manutenção do estado de tensão que os intervalos de segundas alternadas geram. Esses apoios e descansos (ou respiros) vão sendo deslocados para tempos distintos do compasso. $O$ início é em anacruse.

2) Os contrabaixos tocam frases tercinadas, sempre omitindo a cabeça do primeiro tempo. O primeiro contrabaixo toca uma frase mais melódica do que rítmica, na medida em que não repete as alturas. A frase descendente termina no meio do último compasso do ciclo, depois do término da melodia da voz (compasso 4). O segundo contrabaixo exerce mais a função rítmica que é a mais comum em Itamar, agindo no começo dos compassos de maneira simétrica e deixando um longa pausa.

3) O piano não toca acordes no início, toca uma melodia de acompanhamento (que poderia eventualmente até ser executada por um contrabaixo, pois possui a característica de delinear a harmonia utilizando-se de ideias rítmicas repetidas).

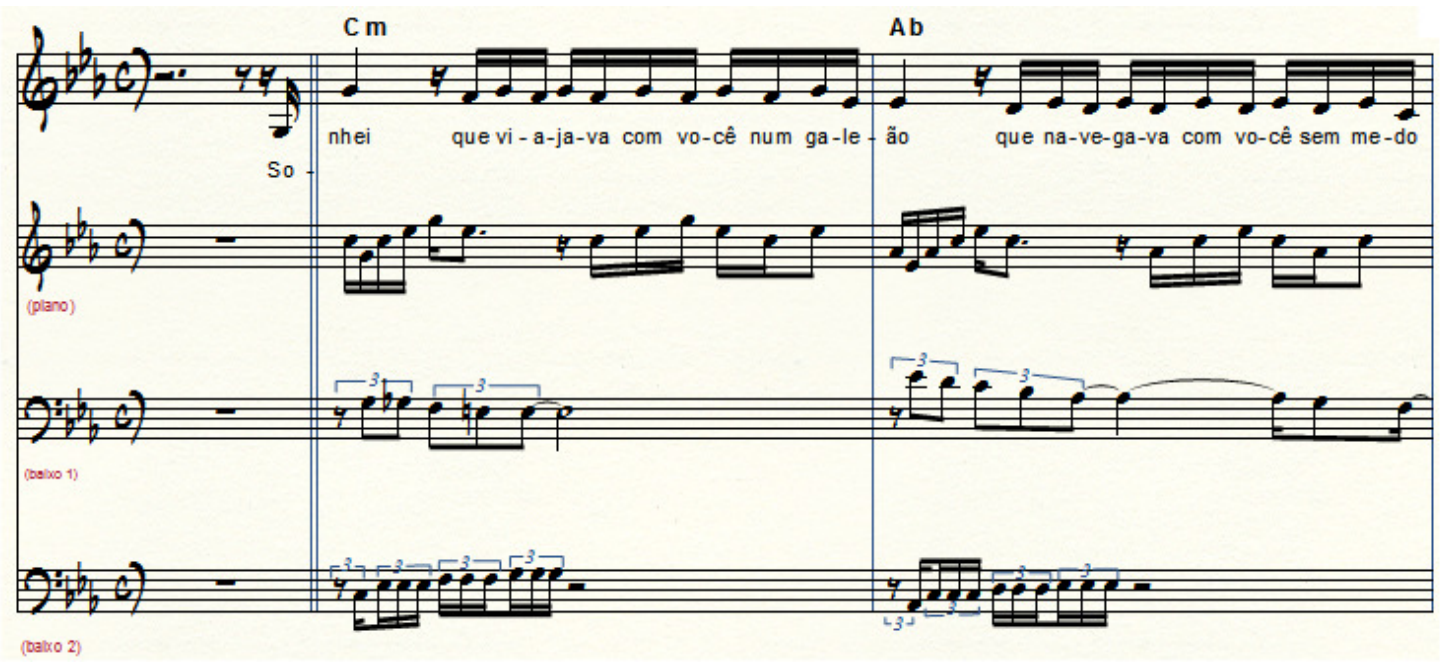




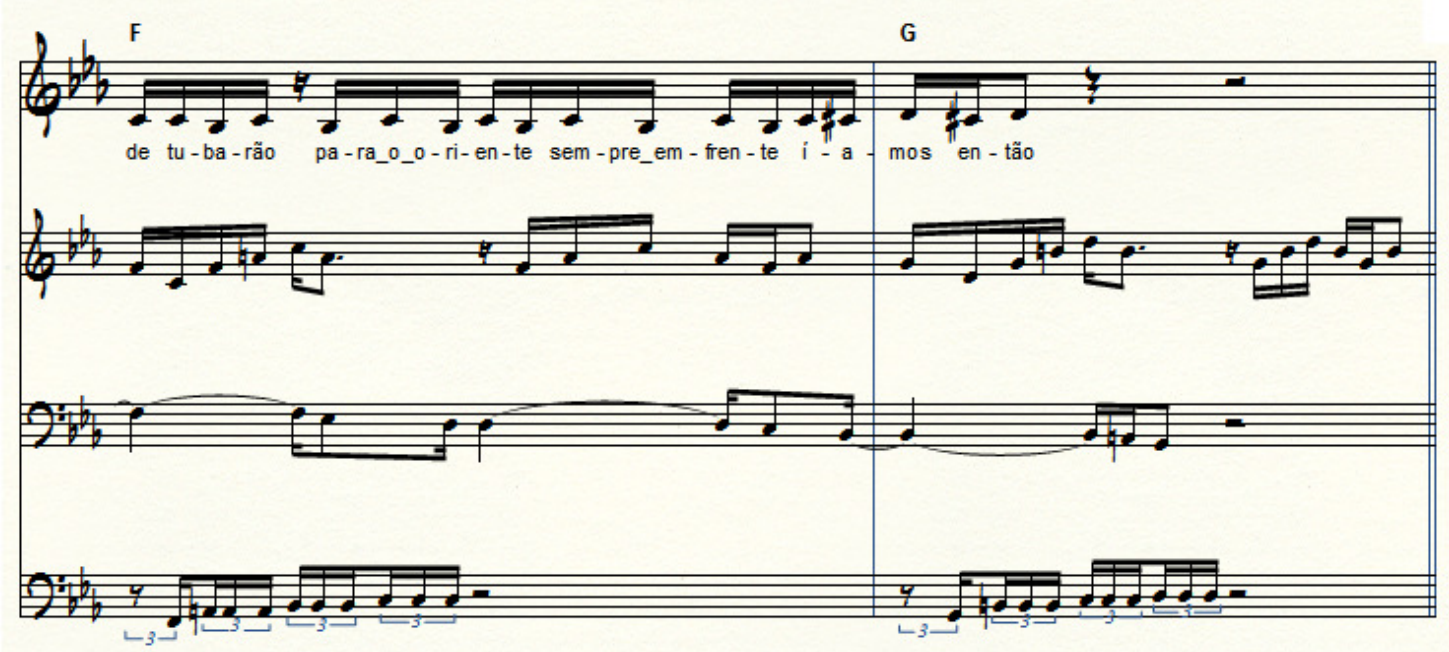

Fig. 4: Sonhei que viajava com você, polirritmia. (CD anexo, faixa 2)

Essa série de disposições dos instrumentos no decorrer do tempo ilustra a ideia de fluxo citada acima. Além disso, evidencia-se aqui também (como veremos outras vezes mais adiante), a presença forte de características rítmicas nas melodias em todos os instrumentos (mais uma vez fazendo jus a música africana e brasileira), mesmo naqueles tidos como prioritariamente melódicos (como a flauta e a voz). Surpreende também a diversidade e simultaneidades de melodias sendo criadas em tempo real, sem o recurso da escrita (partitura ${ }^{41}$ ), e articuladas sucessivamente sem que houvesse uma escuta prévia averiguando a compatibilidade entre elas. Essa canção foi transcrita vários anos após ser gravada, mas o arranjo foi gerado no período de gravação da trilogia Bicho de Sete Cabeças da maneira que acabei de descrever, com Itamar cantando cada frase a cada um dos músicos.

\section{e) Sincretismo musical}

Itamar acabou por realizar essa espécie de sincretismo musical, na tentativa de romper com as linguagens tanto poética ${ }^{42}$ como musical. "A

\footnotetext{
${ }^{41}$ Sabe-se que a inserção da escrita, conforme afirma François Delalande, vista por ele como sendo um tipo de tecnologia, permitiu para a música ocidental o desenvolvimento da polifonia, da harmonia e do contraponto, pois a possibilidade da fixação da informação musical sobre o papel e o olhar posterior sobre a partitura que esse fato permitia, deram possibilidades novas para a combinação do material sonoro que somente a memória não seria capaz de gerenciar (DELALANDE in VALENTE: 2007, p. 54).

${ }_{22}$ Buscou inovações no tipo de construção poética. Além disso, muitas das letras de Itamar são metalinguísticas porque falam claramente sobre suas preocupações enquanto compositor.
} 
novidade vem da informação, e sem informação é impossível" (ASSUMPÇÃO apud PALUMBO: 2002, Vol.1, p.33). Sua inquietação foi se ampliando aos poucos até que se percebesse como compositor e até que entendesse que não bastaria simplesmente adotar algum dos ritmos brasileiros para alojar suas canções. Ele acabou criando seu próprio esteio, e assim um estilo onde pudesse fazer vigorar sua manifestação artística de maneira plena.

$\mathrm{Na}$ época da juventude de Itamar a música popular urbana ${ }^{43}$ já era amplamente difundida pelo rádio. Aquele tal aparelho de rádio que emprestava da mãe o fazia escutar de Tonico e Tinoco à Jerry Adriani ${ }^{44}$. $O$ rádio, foi seu professor, conforme disse. Mesmo assim acabou trocando um radinho de pilha (que havia ganho como presente de seu pai, para ele e o irmão) por um violão, já morando em Arapongas, e aos poucos começou a acrescentar à escuta também o tocar. Descobriu que tinha extrema facilidade para reproduzir (cantando e tocando) o que ouvia. Conseguia ouvir e encontrar o acorde e a batida no violão. E passou a ensinar as músicas da Jovem Guarda aos músicos do conjunto de um amigo de Arapongas para que eles as tocassem em suas apresentações. Ele nem pensava em compor ainda, queria apenas cantar e tocar e era um bom imitador dos intérpretes (Tim Maia, Roberto Carlos, Jorge Ben). "Aprendi tudo de ouvido. Essa foi a minha escola" ${ }^{45}$.

\section{f) Terreiro e Teatro}

Seu pai, Januário, que era fiscal do Instituto Brasileiro do Café (IBC) - cargo vitalício na época - tinha, junto com sua mãe, Cida, um terreiro de umbanda em Arapongas. Itamar, Narciso e Denise passaram a frequentar as sessões e a

\footnotetext{
Neste caso falando sobre o "novo" há a canção "Quem Descobriu, Descobriu" ou o poema que antecede "Prezadíssimos Ouvintes"

${ }^{43}$ Música Popular Urbana é um termo utilizado por pesquisadores para diferenciar a música popular que se desenvolve nos grandes centros urbanos da música popular de caráter mais espontâneo, também chamada de "folclórica", de ambientação mais interiorana e manifestação mais coletiva.

${ }^{44}$ Os primeiros, intérpretes e compositores da música sertaneja e o segundo pertencente ao movimento Jovem Guarda.

${ }^{45}$ ASSUMPÇÃO apud PALUMBO: 2002, p.33. Itamar se viu primeiro como cantor, depois como ator, e finalmente como compositor, agregando todas as habilidades desenvolvidas para ser considerado um artista.
} 
tocar atabaque. Januário era Pai de Santo e Cida recebia as entidades. Nesse fato, mais uma vez a ligação com um tipo de música específico, relacionada à tradição africana que foi recriada no Brasil.

Eu saí da Igreja Católica em Tietê e caí num terreiro em Arapongas. Três vezes por semana era batata! Meu pai sempre fez daquilo a missão dele. A missão dele não era trabalhar no IBC (Instituto Brasileiro do Café). Acho que talento é isso, alguém que tem uma missão. (ASSUMPÇÃO apud PALUMBO: 2002, p.30).

A umbanda, assim como o candomblé, são religiões formadas no Brasil. No caso da umbanda há sincretismo dos orixás com os santos católicos.

Esses fatos pontuam um aspecto importante da postura adotada posteriormente por Itamar em suas apresentações ao vivo, pois viria a ser de uso recorrente em suas conversas a referência ao palco como sendo um lugar especial onde ocorreria um trabalho espiritual semelhante ao das práticas religiosas. Perguntada a respeito de sua opinião sobre as possíveis influências musicais que o convívio no Centro de Umbanda possa ter gerado (tal como a sonoridade rítmica e mântrica em que lá se ouve) e esse aspecto de encarar o palco como local de cerimônia, Serena Assumpção, uma das filhas de Itamar em sua resposta, de algum modo nos fez concordar.

Sim, obviamente a formação musical dele passou pela fundamental experimentação da religiosidade afro-brasileira. E pra ele, estar no palco era uma forma de reviver essas experiências, já que abandonou a religião quando meu avô desistiu do terreiro.[...] A formação musical dele foi muito orgânica. Ele não ficava correndo atrás de música pra escutar... ouvia o que tocava na rádio da casa dele, com os avós. E o terreiro foi mais uma forma de musicalização. Quando se entendeu músico, usou tudo isso e outras coisas pra criar sua própria linguagem, mas também isso se deu de forma inconsciente ${ }^{46}$.

A experiência da prisão, descrita anteriormente, pelo suposto roubo do gravador que havia sido, na verdade, emprestado pelo amigo Domingos Pellegrini, ocorreu quando Itamar tinha 23 anos. Ela parece ter interferido na maneira de Itamar atentar para essas questões, aflorando algumas decisões

\footnotetext{
${ }^{46} \mathrm{Em}$ resposta a perguntas feitas por mim à ela, via e-mail, dia 14 de março de 2011.
} 
latentes. Após alguns dias na cela junto com presos comuns, restaram só ele e mais um homem.

\begin{abstract}
Ficamos eu e mais um sujeito. Esse cara caminhou para o montinho de roupa dele, pegou um livreto de modinhas e falou: você que é músico, sabe tocar isso aqui? Pô aquilo eu sabia, Tião Carreiro e Pardinho, Rio de Lágrimas. O cara começou a chorar. Eu cantava e ele chorava. Então falei: Porque é que você está chorando? Ele: Porque você sabe cantar! Por fim o Domingos Pellegrini apareceu e me tirou de lá. Quando cheguei a Arapongas, contei a história a meu pai e ele me disse: Você precisa desenvolver a sua mediunidade. E eu: Não quero saber desse negócio não. Não quero passar as segundas quartas e sextas me dedicando aos espíritos. Ele respondeu: Se você recusar essa missão sua vida vai ser um inferno. (ASSUMPÇÃO apud PALUMBO: 2006, P.31- 33)
\end{abstract}

Narciso Assumpção ${ }^{47}$, que era o mais velho dos três irmãos, foi o primeiro a participar do GRUTA (Grupo Universitário de Teatro de Arapongas), sob a direção geral de Nitis Jacon ${ }^{48}$, e que se apresentava em Londrina. Ele trouxe consigo, mais tarde, os irmãos. Denise Assunção, que ainda exerce a profissão, participou de vários projetos com o irmão mais velho. Narciso, segundo ela, foi ator, compositor, radialista, repórter, diretor de teatro, autor de peças teatrais e por vezes também redator de discursos de alguns políticos em Curitiba e outras cidades do estado do Paraná. Narciso e Denise foram, respectivamente, premiados nas montagens do GRUTA de "Arena conta Zumbi”, de Augusto Boal e Gianfrancesco Guarnieri, de 1968 como melhor ator e "Arena conta Tiradentes" (também da autoria de Boal e Guarnieri) de 1971, como atriz revelação. Itamar fez o papel de Tiradentes.

Esses dados são interessantes, pois apontam para a ligação desses irmãos com a palavra, e com a interpretação. No teatro a representação transcende a questão do texto, da língua e do conteúdo que as palavras podem portar, pois congrega alguns tipos de competências que são justapostas. Itamar começou a tocar e a compor efetivamente, nessa aproximação com o teatro. Narciso escrevia textos e eles tentavam montar para encenar. Foi a primeira vez que em que se viu com um violão tentando fazer uma trilha. Depois disso Narciso acabou indo para Curitiba junto com Denise e Itamar permaneceu como os pais.

\footnotetext{
47 Já falecido.

${ }^{48}$ Uma das criadoras do Festival de Teatro de Londrina, que se iniciou em 1968 e prosseguiu por mais de quarenta anos, transformando se no FILO (Festival Internacional de Londrina) até hoje em 2011.
} 
A atuação é um tipo de performance. Esse é um ponto essencial na obra de Itamar. Parte da compreensão de sua música passa pelo entendimento de questões extramusicais. Não basta o fato de nos voltarmos somente para as configurações musicais que são aparentemente mais identificáveis. Importa muito a maneira como as palavras são cantadas, o gestual adotado e os figurinos utilizados. O exercício desse fazer possivelmente veio do teatro. Nesse sentido ele acabará congregando a necessidade de caráter espiritual ${ }^{49}$, com um meio e uma competência efetivos para apresentar sua obra, através da atuação e da valorização da performance. Na sequência de competências adquiridas em sua formação Itamar se conscientizou então de mais um atributo, a capacidade de atuar.

Em 1971, Itamar participou do IV Festival Universitário Música Popular de Londrina com a canção Caboclo da Mata. Essa composição era essencialmente um ponto de terreiro e dizia: "Caboclo da mata, por quem come fogo?". Ele e os irmãos a tocaram. O júri acabou criando o prêmio "Melhor Apresentação Total" por causa da atuação impactante. Mais uma vez em 1972, no mesmo festival, a mesma premiação para as músicas Queimada e Tempo Completo.

As composições de Itamar, nesse período, ainda tinham um caráter bem distante daquele que viria a delinear sua obra, na visão de Arrigo Barnabé ${ }^{50}$. A primeira vez que o viu no palco achou que sua figura cênica era impressionante apesar de não se empolgar tanto com as composições. Itamar ainda não tinha a concepção clara, segundo Arrigo, de que a base podia estar deslocada da melodia. Para Arrigo o marco de composição onde Itamar de fato encontrou seu estilo se deu com Nego Dito ${ }^{51}$.

Algumas das primeiras composições continham letras de protesto, possivelmente estimuladas, acredita Arrigo, pela participação de Itamar no GRUTA, já que era um grupo engajado, em pleno período de ditadura militar no

\footnotetext{
${ }^{49}$ Conforme ele expressa claramente no relato sobre a prisão em Vozes do Brasil, Vol.1. (p.3233).

${ }^{50}$ Fala em entrevista anexa.

${ }^{51} \mathrm{~A}$ canção ficou em $3^{\circ}$ lugar no $2^{\circ}$ Festival da Feira da Vila Madalena, em 1980. É interessante o nome da banda que o acompanhava Mão de Pilão. O pilão é um objeto bastante relacionado à época da escravidão, originário da culinária africana, como se sabe, com finalidade de triturar alimentos. Ele também é utilizado como insígnia de alguns orixás nas religiões afro-brasileiras.
} 
Brasil. Para Arrigo, essa característica de engajamento e revolta expressas nas primeiras canções não correspondia à uma necessidade real de Itamar, conforme veio a perceber depois de conhecê-lo. Eles se tornam amigos em 1973, durante os ensaios para um show coletivo de vários compositores, que ocorreu num lugar chamado $\mathrm{Na} \mathrm{Boca} \mathrm{do} \mathrm{Bode,} \mathrm{em} \mathrm{Londrina.} \mathrm{Itamar} \mathrm{já} \mathrm{estava}$ se tornando um compositor. "Só fui sacar que era compositor ouvindo outras músicas" (ASSUMPÇÃO apud PALUMBO: 2002, p.33).

\title{
1.2 UM AMIGO CHAMADO ARRIGO
}

\author{
Onde estará Avrigo Barnabé \\ At ás da estátua do Borbe-Gato \\ Viva o Amigo Barnabé \\ O resto depois eu digo \\ Tenho um amigo chamado Arrigo \\ O res to depois eu digo \\ A Lira Paulistana já criou fama
}

Fig. 5: Amigo Arrigo, letra. (CD anexo faixa 3)

A letra, quando cantada, no CD Pretobrás, troca as palavras "Arrigo" por "amigo", transformando a frase em: "Onde estará o amigo Barnabé?". "O Arrigo é mais que um irmão para mim. As nossas diferenças se completam" ${ }^{52}$. Essa declaração sugere, além da amizade, o diálogo musical que podiam travar. As diferenças, a que se refere não são somente as de personalidade, são diferenças musicais. Esse encontro foi fundamental para que ambos acirrassem suas próprias características enquanto compositores. Perguntado sobre se o fato de ter dito: "hoje (em 2002) em dia não ouço mais nada, porque não há mais novidade para meu ouvido", significava não haver mais nada a se fazer em música Itamar respondeu:

${ }^{52}$ ASSUMPÇÃO apud PALUMBO: op. cit., p.36. 
Eu tenho a novidade! A novidade vem da informação, sem informação é impossível. Eu não seria Itamar Assumpção se não tivesse conhecido o Arrigo, é nesse sentido que estou falando. Mas não é só conhecer o Arrigo como compositor, é compreender a música dele. Antes de terem compreendido o Arrigo já falavam: "Olha, isso aí não dá". Porque realmente dá trabalho. $O$ novo dá trabalho, muito trabalho. $O$ novo está ligado à tudo. $O$ Arrigo está ligado a tudo, à vanguarda que conhece Proust e Orlando Silva. (ASSUMPÇÃO apud PALUMBO: 2002, p.33).

Embora Itamar ainda não se enxergasse como compositor de fato, já havia feito, nesse período, algumas das canções que ganhariam mais tarde a roupagem impactante dos arranjos, tal como Luzia, Prezadíssimos Ouvintes, Fico Louco. Por sua vez Arrigo Ihe mostrou Clara Crocodilo, que Itamar achou "meio esquisito, diferente." (ASSUMPÇÃO apud PALUMBO: 2002, p.30). Estrela Ruiz Leminski, em seu estudo sobre a Vanguarda Paulista ${ }^{53}$, referindose à proximidade entre as características da Poesia Marginal e o teor das letras expressas nas canções dos diversos autores do movimento, observa a grande distância temporal que existiu entre a produção de algumas dessas composições e sua efetiva gravação e divulgação através dos discos. No caso de Itamar e Arrigo, nota-se que as canções foram compostas no início dos anos de década de 1970 para serem registradas em disco somente no final da década e inicio dos anos $80^{54}$.

Esse fator circunstancial acabou por dar oportunidade a ambos de constituírem e desenvolverem com mais profundidade as características de suas obras e confirmarem um estilo próprio.

Embora as canções já estivessem prontas, o fato de um tomar contato com a obra um do outro (e no caso de Itamar fazendo parte da banda de Arrigo, portanto como músico e arranjador, inclusive), fez com que houvesse

\footnotetext{
${ }^{53}$ LEMINSKI: 2011, p.61.

${ }^{54} \mathrm{Em}$ seu estudo Estrela aborda a questão da indústria fonográfica alterando seu modo de operar, a concomitância histórica com a abertura política no Brasil e o início do surgimento dos pequenos selos de gravação e de produção independente. Hoje em dia com os meios digitais de produção, podemos observar que os compositores não dependem mais de gravadoras e que a composição pode eventualmente ser até quase que imediatamente gravada, por causa da acessibilidade que esses meios permitem (de custo inclusive). Há outras questões envolvidas, tal como alterações no suporte que serve de meio (que poderão levar à extinção do $\mathrm{CD}$ ), veiculação e comercialização através da Internet, mas que não nos cabe discutir aqui. $O$ fato é que havia uma série de dificuldades que acometiam os compositores da época. A realização de shows não era dificultosa, pois havia espaços para se tocar, mas a gravação sim, acrescido o fato de que gravar era uma espécie de legitimação da qualidade artística.
} 
uma troca de informações bastante intensa. Itamar interveio na música de Arrigo, com arranjos em parceria com Paulo Barnabé ${ }^{55}$, irmão de Arrigo, em duas músicas (Diversões Eletrônicas e Infortúnio) da saga de Clara Crocodilo.

\section{a) Dodecafonismo e Jimmi Hendrix}

A sonoridade do dodecafonismo era conscientemente experimentada por Arrigo ${ }^{56}$. Para melhor realizar a tarefa de arranjo que Arrigo the encomendara Itamar teve que aprender sobre esses processos composicionais. Arrigo conta que houve um dia em que ele deu uma aula sobre o assunto explicando a Itamar e a Paulo, as técnicas que utilizava, justamente por causa da incumbência dada a eles. Ao mesmo tempo em que Itamar entrou na música de Arrigo, foi lá onde experimentou primeiro os procedimentos de arranjo que adotaria em sua própria música tornando-os quase que indissociáveis da composição.

Falamos então dos anos que se seguem a 1973, quando Itamar mudouse para São Paulo, e a ideia de se assumir como compositor já era bem mais palpável. Trabalhando como entregador de carnês de IPTU (Imposto Predial e Territorial Urbano) pôde conhecer a imensidão da cidade de São Paulo ${ }^{57}$. Passou a fazer parte da banda de Arrigo, no princípio cantando e depois tocando baixo (mas mantendo paralelamente seu próprio trabalho de composição), já que os irmãos Barnabé também estavam radicados em São Paulo e acabou indo morar como eles, perto da represa de Guarapiranga.

Segundo Paulo, ele e Itamar estreitaram muito as relações. Ensaiavam muito juntos. Itamar já tinha uma afinidade com o contrabaixo, e Paulo tocava bateria e percussão. Mas durante os ensaios experimentavam tocar outros instrumentos que estivessem à disposição, como piano e guitarra além de

\footnotetext{
${ }^{55}$ Entrevista anexa (Anexo 2).

${ }^{56}$ Embora Arrigo afirme que somente depois de haver entrado no curso da Escola de Comunicações e Artes da USP (Universidade de São Paulo) é que aprendeu o que era dodecafonismo de fato. Antes ele compunha de ouvido, tendo como referência outras sonoridades como as de lgor Stravinsky e Béla Bártok.

${ }^{57}$ Itamar se referia a sua relação com a cidade de São Paulo: "não é amor, é identificação total". Há várias letras que falam sobre a cidade e sobre a urbanidade.
} 
trocarem o contrabaixo pela bateria. Isso Ihes deu uma grande versatilidade. Havia também sessões de escuta.

Itamar falava, nas conversas, de Jimmi Hendrix, de haver ficado cerca de um ano escutando os discos para destrinchar e entender o que ocorria na música dele (ASSUMPÇÃO in PALUMBO: 2002, p.33). Já Paulo cita Bob Marley e Miles Davis. Ouvir esse tipo de música na década de 1970 era uma grande novidade aqui no Brasil, segundo ele, e ambos se dedicavam exaustivamente à escuta. Procuravam nas canções qualquer informação musical que gerasse um interesse diferenciado e detinham-se em determinados trechos das músicas até que pudessem detectar todas as informações e tornarem-se conscientes das ideias musicais presentes. Em Bob Marley, observa Paulo, há as "linhas de baixo que atravessam a métrica e concluem em outro lugar".

Em Jimmi Hendrix, podemos ouvir as linhas de baixo dobradas com as linhas de guitarra, procedimento bastante presente nos arranjos dos primeiros discos de Itamar. Para Paulo, foi nesse período de estudo em que Itamar começou a gerar a concepção de linha de baixo que tornou sua obra tão impactante. Como tinham uma maneira de pensar muito semelhante puderam trabalhar juntos nos arranjos que Arrigo pedira. A facilidade com ritmo e suingue que os dois possuíam completou as informações para o arranjo de base. Assim como Arrigo, Paulo acredita que a convivência, dentro daquele grupo de amigos, que se reunia na casa perto da represa por aquele breve período, de cerca de dois anos, foi decisiva para todos e também para Itamar. Havia quem fotografasse como A.C.Tonelli, e conversas sobre literatura e livros de histórias em quadrinhos circulando, num contexto de vida urbana ${ }^{58}$.

A banda de Arrigo teve que ser formada porque o maestro e arranjador Rogério Duprat ${ }^{59}$ havia oferecido o estúdio para que ele gravasse suas músicas. Mas as gravações não deram certo. As músicas eram muito difíceis,

\footnotetext{
${ }^{58}$ Assim como a poesia marginal incorporou os ruídos urbanos (como a pichação, o palavrão e o humor) conforme lembra Estrela Ruiz, podemos dizer que a paisagem sonora urbana (no conceito de Murray Schafer) foi incorporada de maneira bastante intensa na música de Arrigo Barnabé.

${ }^{59}$ Itamar relatava a importância de ter tido esse "aval" de Rogério Duprat, como sendo um fator que lhe deu segurança e certeza de que era um artista. O nome de Rogério Duprat é um elo entre o Tropicalismo e a Vanguarda Paulista, fato que discutiremos adiante.
} 
segundo Arrigo, e a voz de Itamar (embora fosse muito bonita, na opinião de Arrigo) não era adequada para cantá-las. $O$ estúdio também foi oferecido para Itamar que gravou três de suas canções ${ }^{60}$. Contou com Paulo Barnabé, e ambos tocaram todos os instrumentos. Por algum tempo a banda de Arrigo foi a mesma que a de Itamar. Itamar abria os shows de Arrigo. A ideia que ele tinha era a de tocar baixo e cantar, mas acabou preferindo só cantar, e às vezes tocar violão.

Em 1977 Arrigo convidou novamente Itamar para ingressar na Banda Sabor de Veneno já que para ele "Itamar era o baixista com quem mais gostava de tocar", mas o nascimento de sua primeira filha com Zena e o rumo que sua música estava tomando, obtendo aceitação, não lhe permitiram voltar.

\section{b) Diversões Eletrônicas e Infortúnio.}

Para os arranjos das duas canções pertencentes à saga de Clara Crocodilo, após a aula sobre dodecafonismo, Paulo e Itamar reelaboraram as informações para aplicá-las às composições de Arrigo e para si mesmos, da maneira que suas vivências permitiam, segundo Paulo. As linhas de baixo foram compostas por Itamar através de um "pensar intuitivo, sobre uma ideia rigorosa". Aliada à intuição, havia, no entanto, muita dedicação. Apesar de ter a informação sobre o dodecafonismo Itamar não queria necessariamente, na opinião de Paulo, se aprofundar no assunto, já que estava ele mesmo desenvolvendo seu próprio caminho, e apenas utilizando a informação necessária para executar o arranjo de base que Arrigo precisava. Percebendo a estrutura do dodecafonismo juntamente com a presença de compassos mistos presentes na música de Arrigo ele conseguiu criar soluções muito fluentes, na opinião de Paulo: "tem que ser muito bom, muito talentoso", para conseguir intervir dessa maneira. Os arranjos foram preparados para um Festival de Música do grupo AMA, em $1978^{61}$, segundo Arrigo, um pouco antes

\footnotetext{
${ }^{60}$ Infelizmente essas gravações se perderam.

${ }^{61}$ O grupo AMA era uma escola de música e editava uma revista periódica chamada VIGU (violão e guitarra) vendida em bancas de jornal, e que continha letras e cifras de canções brasileiras ou estrangeiras que tocavam nas rádios, entre os anos da década de 1970 e 1980.
} 
do $1^{\circ}$ Festival Universitário de Música Popular Brasileira promovido pela TV Cultura em 1979.

Em Diversões Eletrônicas, Paulo sugeriu que fizessem algo relacionado à Disco Music, que se remetessem ao filme Saturday Night Fever ${ }^{62}$. Isso o fazia lembrar os jogos de fliperama, da noite, da bebida, como um evento urbano. A partir da linha original de Arrigo, Itamar foi criando respiros (fig.6), alterando-a aos poucos e gerando suingue. Colocava as notas da série, mas num fluxo que alterava o ritmo para gerar balanço, segundo Paulo: "nosso negócio era levar a coisa para o suingue, com cara de rock, de música Black".

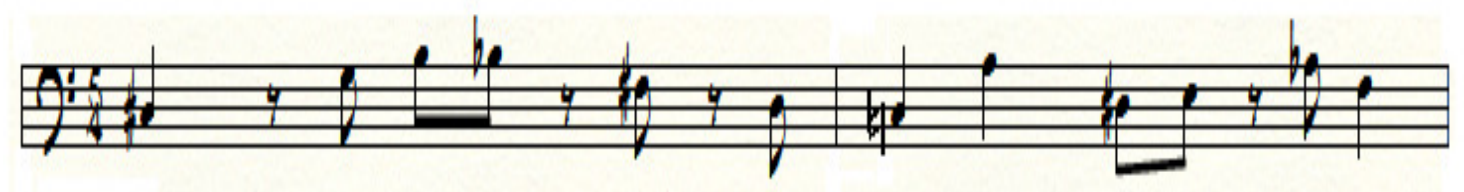

Fig. 6: linha de baixo dodecafônica de Diversões eletrônicas. (CD anexo faixa 4)

Essa é a linha de baixo que foi alterada do original composto por Arrigo, mas a referência à disco dance ocorre mais precisamente na introdução (fig.7), quando aparecem oitavas sucessivas, típicas do estilo, acrescidas das pausas, os tais respiros a que Paulo se refere.

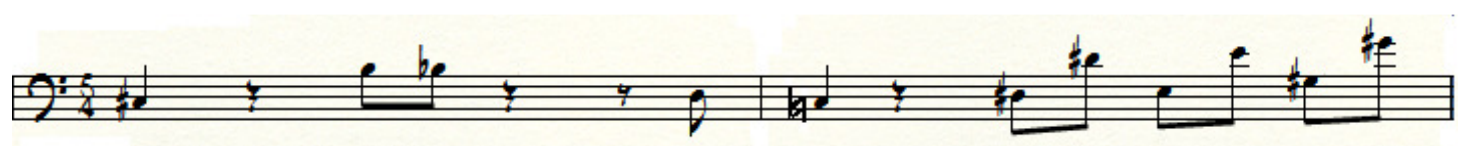

Fig. 7: Diversões eletrônicas, introdução.

Em entrevista à Renata Jamberg ${ }^{63}$, Arrigo responde à pergunta sobre a propriedade ou não de se considerar que, no álbum Clara Crocodilo, a maior parte das músicas tenha partido do contrabaixo, e se haveria uma potência rítmica no dodecafonismo, eventualmente intuída por ele, de gerar células repetitivas e dançantes:

\footnotetext{
${ }^{62}$ Filme norte americano, de 1977, dirigido por John Badham e estrelado por John Travolta, que aborda a chamada era disco.

${ }^{63}$ ARRIGO apud JAMBERG: 2010.
} 
As músicas Clara Crocodilo, Diversões Eletrônicas e Acapulco Drive-in começaram a ser feitas no baixo. Na realidade, as frases de baixo na música Clara Crocodilo podem ser tocadas por qualquer instrumento. Quer dizer, pensamos (eu e o Mário Cortes ${ }^{64}$ ) em frases que tivessem independência e vitalidade...na música Diversões Eletrônicas e criei uma linha de baixo para o piano e o Itamar deu uma mexida nela para passar para o baixo elétrico. Acapulco foi pensada de maneira parecida com Clara Crocodilo, as linhas de baixo podem ser transpostas para qualquer instrumento, têm uma qualidade melódica evidente e se comportam como módulos, que permitem combinações e recombinações. (ARRIGO apud JAMBERG: 2010, p.58)

Há aqui duas questões. Primeiro, a semelhança existente entre as maneiras de escuta das composições de Arrigo Barnabé e de Itamar Assumpção. As melodias das frases comandadas pelo contrabaixo, subjacentes ao ritmo, parecem induzir-nos de fato à uma escuta horizontal, afastando-nos da ideia de melodia acompanhada. Em sua resposta acima, Arrigo utiliza termos semelhantes aos que podemos observar na música de Itamar, tal como a possibilidade de combinar as frases em módulos, ou tocá-las em qualquer outro instrumento. Arrigo justifica:

É tudo polifonia, Clara Crocodilo é um álbum para quem tem escuta horizontal. Por isso muita gente não entende a música. Muita gente pensa verticalmente, acompanhamento e melodia. Quer dizer, quem escuta verticalmente não vai entender mesmo, não há nada para ser ouvido assim, salvo Instante ${ }^{65}$. (ARRIGO apud JAMBERG: 2010, p.59)

A segunda questão trata de observar a facilidade com que cada um utiliza a harmonia e o ritmo, respectivamente. Para Arrigo, Itamar tinha uma limitação em relação ao conhecimento de harmonia (fato do qual Itamar evidentemente era consciente). Mas dentro dessa restrição acabou encontrando diversas soluções e saídas, demonstrando, na opinião de Arrigo, uma incrível criatividade. Essa limitação the conferiu uma maneira peculiar de compor. Por sua vez Arrigo afirma que nunca teve facilidade rítmica, nesse sentido mencionado anteriormente, de saber como gerar o suingue, 0 "deslocamento", a propensão ao dançante. Sua música é híbrida, pois adota o

\footnotetext{
${ }^{64}$ Parceiro de autoria na música Clara Crocodilo.

${ }^{65}$ Referindo-se, evidentemente, à música Instante e às demais composições do disco Clara Crocodilo.
} 
dodecafonismo em alguns momentos, sem se dirigir necessariamente ao atonalismo no sentido de ausência de polarizações. $O$ fato de haver repetições e ostinatos terminou por gerar alguma polarização sobre determinada nota, "geralmente a primeira, assume o papel de centro" (op.cit: 2010, p.59). Portanto o trabalho rítmico que Itamar e Paulo Barnabé desenvolverem, tanto nos arranjos de base como enquanto músicos, tocando, deixou marcas reconhecíveis na obra Arrigo. E vice-versa.

A música Infortúnio (fig.8) teve a linha de contrabaixo composta por Itamar, utilizando uma série dodecafônica. Segundo Arrigo: "ele fez o contraponto rítmico com a frase do teclado e eu ia dizendo a ele que notas podiam ser usadas para fazer a série" (ARRIGO apud JAMBERG, 2010, p.58). Podemos observar que há uma acomodação da linha de modo a priorizar 0 ritmo. Uma vez que ocorre repetição de nota (Si), não há aqui a preocupação em seguir rigidamente as regras do serialismo dodecafônico. Essas repetições ajudam a ressaltar a sensação de deslocamento, a qual vimos nos referindo.

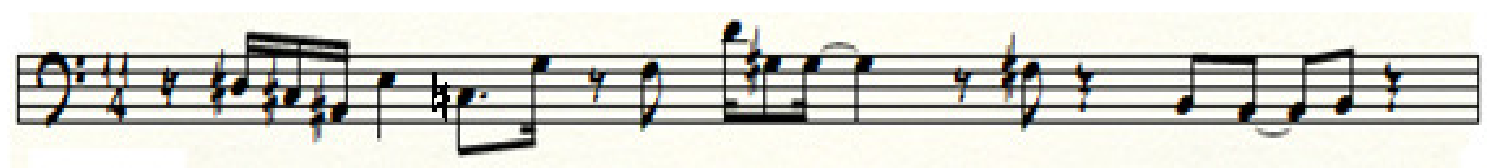

Fig. 8: Infortúnio, trecho da linha de baixo. (CD anexo faixa 5)

A linha de baixo se consolida aos poucos durante a música. Após o início da introdução-abertura de cello e voz segue-se uma espécie de desenvolvimento com os sopros, instrumental. A entrada da percussão (bateria) coincide com a entrada do baixo (1'44") onde juntos tocam fragmentos pinçados dessa linha, antes de ela ocorrer de fato. Esse trecho que antecede a melodia do baixo foi escrito por Arrigo, utilizando-se da omissão de algumas de suas notas. Esse procedimento cria expectativa e tensão. Quando a linha é tocada inteira parece precipitar a junção das peças que mostrarão, o fluxo do desenho em movimento, para a história, que havia ficado no ar, continuar a ser contada. 
Apesar da música de Arrigo ser notadamente densa, na medida em que congrega diferentes e variados acontecimentos simultâneos, Itamar consegue encontrar enormes espaços de silêncio. Isso não quer dizer que Arrigo não os busque também (vide o trecho com as omissões). Mas mesmo dentro de um compasso ímpar e longo, como o desse trecho, Itamar demarca um ciclo. Mostraremos que esse tipo de densidade já não é tão ocorrente em suas próprias composições ${ }^{66}$, mas a busca do silêncio sim.

\section{c) Silêncio}

Aqui se abre mais uma porta para discutir a obra de Itamar. "Quando não há som, a audição fica mais alerta", diz Murray Schafer ${ }^{67}$ (SCHAFER: 1997, p.358). Na música de Itamar, o estado de alerta do ouvinte parece ser requisitado o tempo todo. Ele é obtido, entre outros recursos, através do controle desses bolsões de ausência de som, ou da contenção de sua propagação, através da dinâmica. Um exemplo notável é a canção Amanticida (parceria com Marta Amoroso), ou o arranjo de Negra Melodia (de Wally Salomon e Jards Macalé), ambos do disco Às próprias custas S.A., principalmente através das pausas contidas na linha de baixo (dobrada com guitarra inclusive, na segunda canção). Ao mesmo tempo em que essas pausas ocorrem, os outros instrumentos permanecem atuando numa dinâmica baixa, reforçando a ideia do silêncio, que por esse motivo se torna contornado, marcado. O estabelecimento dessas relações, desses planos, através das intensidades sonoras, consumava-se principalmente ao vivo, quando havia a possibilidade mais intensa de ocorrer intercambio entre os músicos, e entre a plateia e o espetáculo.

\footnotetext{
${ }^{66}$ Exceção feita a alguns dos arranjos das composições que se pode ouvir nas gravações dos discos, onde, segundo Paulo Le Petit (baixista da banda Isca de Polícia, que o acompanhou por muitos anos) pelo fato de ter o recurso de utilizar vários canais, Itamar queria ocupa-los de qualquer maneira, pois não Ihe faltavam ideias. Isso nem sempre gerava um resultado musical tão satisfatório, na opinião dele. Opinião que é também compartilhada por outros músicos que o acompanharam. Durante os shows ao vivo, no entanto, a instrumentação era menor (ou no único disco gravado ao vivo que é o "As Próprias Custas S.A.") essa característica dos espaços vazios aparece. Com a banda Orquídeas do Brasil, que possuía dez musicistas, a densidade volta a prevalecer, mesmo nos shows.

${ }^{67}$ Schafer, em seus estudos de mais de quatro décadas, faz considerações muito importantes sobre o silêncio, reflexões que utilizaremos para ajudar a falar sobre a obra de Itamar. Criou diversos conceitos tais como os de Paisagem Sonora, Esquizofonia, e outros que nos auxiliam a entender as mudanças nos modos de escuta ocorridas no século XX.
} 
Regina Porto ${ }^{68}$ aponta, em fala proferida no debate incluso no livro $A$ Música na escola ${ }^{69}$, a importância de se detectar o silêncio na música, de que ele esteja contido nela, e de que sejamos preparados para escutá-lo:

Quero falar de um silêncio como ideia de silêncio ativo, do qual você participa de algo que está acontecendo. O exemplo de silêncio do século XX foi o de John Cage; o do século XXI foi uma performance recente, com o maestro Claudio Abbado regendo a Nona de Mahler quando o público, terminada a apresentação, ficou 1 minuto e 46 segundos em silêncio. Este é um silêncio ativo, porque as pessoas estão vivendo aquela musica e tiveram uma reação vivida. É como se ficasse um residual musical, e eles tentassem resolvê-lo internamente, em suas cabeças.[...]

Não existe música sem o silêncio. O silêncio é você estar internamente quieto, concentrado, focado naquela música, erudita ou popular, numa situação individual ou coletiva.[...] Voltando à premissa do silêncio como etapa primordial para a escuta, resumiria que ouvir uma música requer um estado de silêncio interior, que é a escuta interior. A segunda premissa é que ouvir o outro requer silêncio. $E$ esse ouvir em silêncio é também um diálogo.[...] Se estou ouvindo o outro em silêncio significa que estou prestando atenção nele, que estou tentando entender aquela alteridade; estou admitindo e estabelecendo uma diferença, e respeitando.

Ou seja, quando a composição oferece espaços de silêncio abre-se a possibilidade de ocorrer um intercâmbio profundo com o ouvinte, que pode se ouvir e se ver nesses momentos. Muito da performatividade de Itamar advém da consciência com que forja esses espaços. No exemplo a seguir (fig.9), o arranjo de Itamar para a canção de Jards Macalé e Wally Salomon, Negra melodia, a escuta permite compreender a densidade desses espaços:

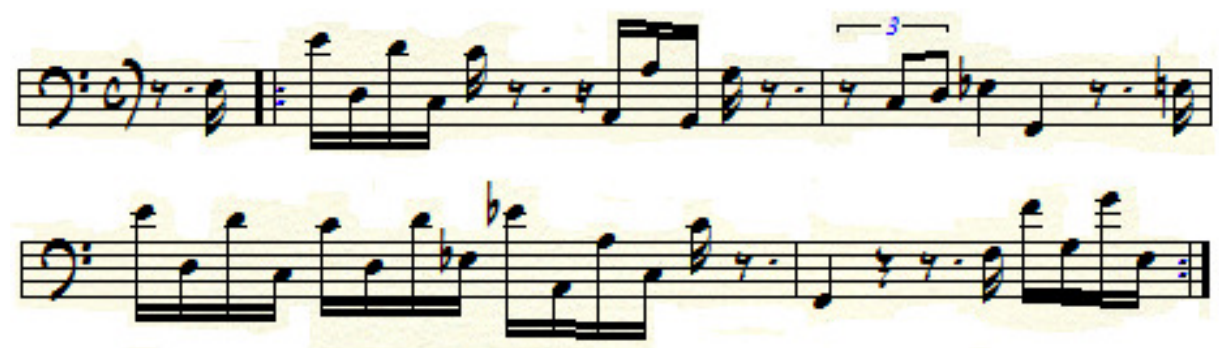

Fig. 9 Negra melodia, arranjo de linha de baixo para a canção de Jards Macalé e Wally Salomão, o silêncio em evidência. (CD anexo faixa 6 )

\footnotetext{
${ }^{68}$ Compositora, parceira de Arrigo Barnabé na canção Diversões Eletrônicas, (ou Num antro sujo, título da canção na regravação da saga de Clara Crocodilo, realizada em 1999) e coincidentemente participante da banda Sabor de veneno na época em que Itamar tocava com Arrigo.

${ }^{69}$ PORTO apud JORDÃO, ALLUCCI, MOLINA, TERAHATA: 2012, p.130-131.
} 
Este é mais um entre outros exemplos de arranjo que utilizam o pensamento de horizontalidade ${ }^{70}$ que poderemos encontrar, sem a utilização de acompanhamento harmônico, através de acordes. Itamar inicia com os instrumentos, oitavando a linha de baixo com a voz de maneira onomatopaica, imitando as articulações expressas pelo instrumento. Quando abandona esse procedimento passa a cantar a melodia sobre essa linha original, que continua sendo tocada pelo contrabaixo e pela guitarra. Há dois aspectos que fazem notar o silêncio. Primeiro a execução num andamento lento, em torno de 54 b.p.m., que torna as pausas longas e inesperadas (através das figuras rítmicas escolhidas para fazerem-nas ocorrer). A bateria não efetua uma condução que marque as pulsações conforme é o procedimento comum, estabelecendo uma "levada" (segundo o jargão popular denomina), ela se molda sob as mesmas divisões rítmicas dos outros instrumentos, e por isso as pausas ficam de fato sem serem preenchidas com sons. E segundo, o fato da voz dobrar a linha de baixo. A voz humana alinhando-se à voz do instrumento traz à melodia que articulam um caráter de cumplicidade mútua. Uma se torna a outra e viceversa. Essa voz que não diz palavras contém um significado enigmático, subjetivo. E é ele quem irá conversar e se justapor à melodia que diz o poema. $O$ silêncio estaria também nesses hiatos de significação. $O$ ouvinte é capturado entre outros aspectos, através desses espaços.

\section{d) Musica imagética}

"Ouvidos atentos". São as palavras pronunciadas, no disco Beleléu, Leléu, $E u$, antecedendo a última canção "Nego Dito" (CD anexo faixa 4), de seu primeiro disco. Nota-se sua preocupação com que o ouvinte exerça uma escuta consciente e ativa. Itamar busca capturá-lo também pela construção de imagens, num primeiro momento, mais literais e com o passar tempo de desenvolvimento do seu trabalho, mais poéticas.

\footnotetext{
${ }^{70}$ A concepção de arranjo desta canção demonstra o quanto Itamar estabelece um vínculo entre a sonoridade que se pode alcançar através dele e a composição propriamente dita. Ligando-os a ponto de torna-los indissociáveis. A autoria desta canção poderia até ser atribuída ao próprio Itamar dada maneira como é apresentada, pertinente ao estilo que estabeleceu.
} 
E segue: "Finalmente Beleléu e a banda Isca de Polícia resolveram se entregar após um longo período de resistência. Eis aqui em primeira mão as verdadeiras identidades desse perigosíssimo bando". Ele irá apresentar os músicos que tocaram no disco, mas esse preâmbulo nos faz confundir as identificações. Itamar é o Beleléu? Os músicos são eles mesmos? Porque "perigosíssimo bando"? Essa maneira de contar lembra muito a linguagem das histórias em quadrinhos, da qual sem dúvida Arrigo já vinha usufruindo. Porque esse bando deve se entregar? Talvez como o office-boy (da saga Clara Crocodilo) que recebeu a "injeção especial", se transformou no monstro Clara e está acuado em um esconderijo recém-descoberto. A urbanidade já está bem presente nesse seu primeiro disco, e transformada em relação ao ponto de terreiro $^{71}$ que dizia fazer quando ainda não se considerava exatamente um compositor.

\section{e) Missa in Memoriam}

Num dos dias próximos à data em que Itamar faleceu (dia 12 de junho de 2003), Arrigo recebeu a encomenda de compor uma missa em homenagem a Arthur Bispo do Rosário ${ }^{72}$. Essa coincidência lhe tocou de alguma maneira. Arrigo aponta semelhança entre os dois, Arthur Bispo do Rosário e Itamar Assumpção no sentido artístico. Bispo do Rosário tem um trabalho minucioso de bordados, estandartes e de suas chamadas assemblages. Arrigo observou que ambos tinham o mesmo ímpeto de junção de materiais (sobre o qual já falamos a respeito), através do recolhimento de sobras e sua posterior transformação, tendo por consequência a criação de um novo objeto. Desse processo, o artístico surgiria com a ressignificação de algo que em princípio não tem valor.

Poucos anos depois, compôs a missa para o amigo (CD anexo faixas 4,5,6,7 e 8), entre 2005 e 2006.

\footnotetext{
${ }^{71}$ Tal como Itamar denominava suas próprias composições do período.

72 Bispo do Rosário foi um artista plástico que viveu por cinquenta anos internado em um hospício do subúrbio carioca, a Colônia Juliano Moreira. O belo livro de Luciana Hidalgo Arthur Bispo do Rosário - o senhor do labirinto, biografa a formação do estado de esquizofreniaparanóica à sua eleição ao status de artista plástico.
} 


\begin{abstract}
Nunca me imaginei escrevendo uma missa para o Itamar. Aliás, sempre me pareceu mais lógico o contrário, pois Itamar tinha uma saúde de ferro, nunca adoecia. Mas parece que à partir dos 50 anos, de fato, passamos a viver a experiência de luto, e a tomar consciência da finitude humana, de uma forma muito mais concreta. Então nosso olhar pode se voltar para a espiritualidade não falo de seitas, religiões ou espíritos - mas para a vida que permanece, aquela que não é absorvida no ciclo biológico. Então penetramos em nosso íntimo, em nossa afetividade mais recôndita, e lá encontramos o alimento, a energia que vai nortear o trabalho. Digo que nosso olhar pode se voltar para a espiritualidade, porque essa é uma das possibilidades de nossa alma, mas não necessariamente a única. Para mim foi dessa forma - além do que parecia que o Itamar cada vez mais se voltava para o imperecível - (o que já justificaria uma abordagem espiritual) - e o que nós vivenciamos em nossa estrada, as experiências, angústias e pequenas alegrias divididas, tudo isso criou lastro suficiente para abastecer emocionalmente e para gerar um entusiasmo capaz de alicerçar esta obra. (BARNABÉ, Arrigo. Texto de abertura do CD da Missa in Memoriam Itamar Assumpção).
\end{abstract}

Aqui não cabe analisar a missa, mas é possível observar um pouco sobre a maneira como Arrigo enxerga a presença de Itamar e de sua música. No Kyrie (faixa 4 do CD anexo), há a utilização dos tímpanos de maneira não usual, conferindo um ritmo estável e cíclico, como ocorre na música popular (não só do Itamar). Arrigo utilizou muitas repetições de notas, fato que, para ele também é característico da composição de Itamar. "Benedito João dos Santos Silva Beleléu, Kyrie nego dito está no céu”, diz o trecho da letra (1'22"). Mais uma vez ocorre a mistura do personagem com a pessoa. Aqui há, obviamente, a citação à canção "Nego Dito", que para Arrigo é a que mais representa a maneira de compor de Itamar, e aquela que simboliza o momento em que ele realizou a síntese das informações musicais de que dispunha (conforme já foi comentado). No texto do Credo (faixa 6 do $C D$ anexo) é incorporado o "espírito que anda" (aos 4'55"), numa possível referência à canção Espírito que Canta, do disco Intercontinental Quem Diria Era Só o Que Faltava!!! (o qual Arrigo gosta especialmente). Citando o fragmento da letra (que é da autoria de Paulo Tovar Hummel) não deixa de se referir ao seu significado poético. No Sanctus, que se inicia com o solo de bombardino Arrigo homenageia silenciosamente Itamar, pois escolhe um instrumento que ele sempre lhe dizia querer aprender a tocar. 


\subsection{O EXERCÍCIO DA PERFORMANCE NO TEATRO LIRA PAULISTANA}

Um pequeno teatro localizado em São Paulo, na rua Teodoro Sampaio em frente à praça Benedito Calixto, chamado Lira Paulistana ${ }^{73}$, funcionou de outubro de 1979 à dezembro de 1985. O lugar acolheu a impactante produção cultural chamada Independente do início dos anos 80. Lá ocorriam principalmente shows, e um modo de se fazer música que não era só paulistano (pois havia compositores de diversas localidades), com ares de novidade. Justamente, em referência a esse diferencial artístico exercitado nos espetáculos que ocorriam nesse pequeno teatro, surgiu o termo Vanguarda Paulista. A imprensa escrita passou a designar dessa forma a reunião da série de compositores que se apresentavam naquele espaço, dentre eles Itamar Assumpção. A Vanguarda Paulista, não foi de fato um movimento, pois não havia um manifesto, ou um traço irrefutavelmente comum. Eram artistas e grupos que se apresentavam num mesmo local capaz de acolher seus trabalhos e onde havia um publico receptivo a novidades. Havia notadamente diferenças estéticas e artísticas. No entanto, como apontam alguns estudos, a despeito dessas divergências naturais havia um ímpeto parecido, entre alguns dos compositores e intérpretes, que era 0 de trabalhar a poesia e a interpretação $^{74}$ de uma maneira diferenciada (LEMINSKI: 2011).

\section{A voz da vanguarda paulista e a performance.}

Outro tipo de semelhança foi notada por Regina Machado (MACHADO: 2011) e estaria na exploração diferenciada no uso da voz pelos artistas da Vanguarda Paulista.

\footnotetext{
${ }^{73}$ Sobre a história do teatro e a arte independente há o livro Em um Porão de São Paulo - o Lira Paulistana e a produção alternativa, 2002. São Paulo: Annablume Editora Comunicação.

${ }^{74}$ Estrela Ruiz trata das características poéticas dos autores da Vanguarda Paulista em LEMINSKI, Estrela Ruiz. Ouvidos Atentos: O texto verbal e sonoro na música da Vanguarda Paulista da década de 1980, dissertação de mestrado. Universidade Federal do Paraná no programa de Pós-Graduação em Música. Curitiba, 2011. Regina Machado fala sobre a voz e as características interpretativas dos cantores da Vanguarda Paulista em MACHADO, Regina. A voz na Canção Popular Brasileira - um estudo sobre a vanguarda paulista. Cotia, SP: Ateliê Editorial, 2011.
} 
Machado analisou em seu estudo algumas das canções tocadas e gravadas nesse período, que coincide com os anos de atividade do teatro Lira Paulistana. No caso de Itamar escolheu apenas uma de suas canções, Nego Dito. Essa canção é bastante representativa de seu estilo, e pode ser considerada como um marco (conforme observa Arrigo Barnabé) que passa a definir com clareza os traços de seu estilo. Machado constata aspectos de interpretação onde ocorrem uma enorme variedade de tipos de emissão vocal, tanto do próprio Itamar como das vozes femininas que realizam os vocais. São emissões comprimidas, aeradas, entoativas e onomatopaicas, todas ocorrendo numa mesma canção. Podemos observar que essas informações vocais também contribuem para gerar uma escuta imagética e performática na medida em que, associadas à temática da letra, nos remetem ao ambiente urbano ${ }^{75}$, às estórias em quadrinhos, conforme já foi citado. Essa é também uma característica bastante típica na música de Itamar, a presença da voz feminina funcionando como uma espécie de alteridade, que ora interpela o discurso, ora o reforça.

Uma outra canção de Itamar ilustra a importância do que ocorreu no teatro Lira Paulistana naquele período. "A Lira Paulistana já criou fama", diz a última frase da canção Amigo Arrigo, do último disco Pretobras I. É uma referência dupla. Primeiro ao pequeno teatro Lira Paulistana, e em segundo aos artistas que participaram das apresentações ocorridas nesse local, naquele momento $^{76}$. Em nenhum de seus discos anteriores Itamar cita nominalmente 0 teatro ou a Vanguarda. Quase vinte anos após a gravação do primeiro disco Beleléu, parece olhar para trás como quem já percorreu um intenso trajeto e para para contemplar o entorno.

\footnotetext{
${ }^{75}$ Itamar é interiorano mas acabou tendo um enorme fascínio pela cidade grande, por São Paulo (lugar para onde se mudou em 1973). Demonstra esse misto de admiração e espanto de se viver numa metrópole, num primeiro momento e artisticamente, através da estética impressa em suas canções.

${ }^{76}$ Curiosamente Arrigo Barnabé nunca tocou no teatro Lira Paulistana. A informação consta do livro Em um Porão de São Paulo - o Lira Paulistana e a Produção Alternativa. Laerte Fernandes de Oliveira, p.67. Apesar disso o nome de Arrigo é indissociável da Vanguarda Paulista. Sobre a ausência nos shows do Lira Arrigo explica: "Não toquei com a banda Sabor de Veneno lá. Me lembro que participei com a Vânia Bastos da abertura de um show do Guga Petri. Só eu e a Vânia, piano Fender e voz... O palco do Lira era pequeno para a banda, os equipamentos eram enormes naquela época..."
} 
Na canção Cultura Lira Paulistana (CD anexo faixa 9), do mesmo CD Pretobrás I, se queixa através da letra: "A ditadura pulou fora da política, e como a dita cuja é craca é crica, foi grudar bem na cultura, nova forma de censura". No lugar de Ataulfo Alves, Monsueto, Dona Ivone Lara, Pixinguinha, Elizete Cardoso, Zé Kétti, prossegue, "ficou tiririca pura, porcaria na cultura, tanto bate até que fura". Pede socorro à Elis Regina ${ }^{77}$, como se pudesse intervir. Vanguarda Paulista e Teatro Lira Paulistana estão obviamente ligados, não só pela associação que a imprensa ou as mídias possam ter feito, mas também na visão dos próprios compositores e $\operatorname{artistas}^{78}$.

Há um ponto que deve ser aprofundado, conforme havíamos sugerido anteriormente, que é a questão da atuação de Itamar ao vivo, nos shows, de sua performance, por assim dizer. A performatividade está muito atrelada à situação presencial, em que público e artista estejam no mesmo ambiente confrontando-se em tempo real, segundo Paul Zumthor. Para Zumthor, mesmo com a mediação, através da gravação da imagem e do áudio, ou suas respectivas transmissões pelos meios de comunicação - fato que afastaria o espectador da fonte de emissão e do momento real em que ela ocorre - ainda haveria o traço da performance, mesmo que em menor grau. Deste modo, tendo plena consciência de que a maneira de se dizer é tão importante quanto o conteúdo da mensagem, Itamar era minucioso com os aspectos interpretativos, até nas gravações onde não há o contato com o público.

Itamar pôde desenvolver de fato e aprimorar sua performance nesse período de shows no Teatro Lira Paulista, e naqueles que se seguiram à gravação do primeiro disco. Já havia tocado com Jorge Mautner, e Arrigo Barnabé, sem ainda haver levado seu próprio nome à frente. Muito embora com o grupo Queimada, premiado nos festivais universitários de Londrina entre

\footnotetext{
${ }^{77}$ Uma das maiores cantoras brasileiras, falecida em 1982, quase chegou a conhecer Itamar pessoalmente. Segundo Itamar: "Já tinha ouvido a Elis falar bem de mim, e fiquei todo aceso. Mas ela morreu uma semana antes. Tinha dito que não gravaria nenhuma música minha. Fiquei mal com isso, cara. Pô, sou um compositor e a Elis é alguém! Ela disse que, se gravasse, estaria me colocando no sistema. Só não entrei no sistema porque a Elis não quis. Ela sacava as coisas. Eu ainda não entendia que, se ela gravasse uma música minha, eu entraria para o sistema como João Bosco e Milton Nascimento. A Elis divulgou os caras dentro do sistema. Aliás, o Bocato (trombonista), que conheci com quinze anos e já tocando daquele jeito, também tocou com a Elis. Foi ele que nos levou, a mim e ao Arrigo, até a Elis, até a Rita Lee, até o Ney Matogrosso" (ASSUMPÇÂO apud PALUMBO, 2002, p.39).

${ }^{78}$ Vide os depoimentos de Luiz Tatit e Suzana Salles à Laerte Fernandes de Oliveira no livro Em um Porão de São Paulo,2002.
} 
1971 e 1973, o fator de destaque havia sido justamente a força da performance.

\begin{abstract}
Suas apresentações cada vez mais elaboradas, sempre em companhia do grupo Queimada, geravam expectativa - batuque e ritmo, recriação dos pontos de candomblé, expressão de palco idem, inspirados na ritualística do terreiro de seu pai (biológico) Januário de Assumpção. Os movimentos convulsos de sua musicalidade, mais a magnética presença de seus irmãos Narciso e Denise no palco, muitas vezes como a participação do ator e bailarino Marquinhos Silva, monopolizavam as atenções. Uma mis-un-scéne tão impactante que recebeu tratamento especial dos organizadores do festival londrinense de 1071: o prêmio Apresentação Total especialmente criado para contemplar essa performance inovadora - nascida do forte apelo visual da dança afro, sincronizada ao suingue esperto do futuro Beleléu- , ainda no ano seguinte seria mantido e novamente os agraciaria.(GIORGIO: 2005,p.32)
\end{abstract}

Houve uma sincronia de acontecimentos na carreira de Itamar em relação ao momento em que ela começou a dar certo ${ }^{79}$. No festival de música da $2^{\text {a }}$ Feira da Vila Madalena, em 1980, a música Nego Dito ficou em $3^{\circ}$ lugar $^{80}$. Como parte do prêmio estavam previstas apresentações no Teatro Lira Paulistana, uma vez que Gordo (Wilson Souto Jr., um dos fundadores e sócios do Lira), havia sido convidado para ser jurado. Essa temporada foi bem sucedida, e acabou se estendendo. O sucesso precipitou a decisão de passarem (Gordo e os sócios Chico Pardal e Plínio Chaves) a administrar a carreira de Itamar além da criação uma gravadora, onde o primeiro disco a ser lançado seria o dele, com as canções do disco que veio a se chamar Beleléu. Assim essa parte importante de sua formação pôde se completar nesse período: o exercício cênico sobre sua própria obra.

\footnotetext{
${ }^{79}$ Certo, no sentido de que pudesse viver financeiramente só de música, a ponto de permitir que ele largasse o emprego de entregador de impostos. Zena, sua esposa, conta que esse emprego temporário de Itamar ocorria por três ou quatro meses por ano. Ele fazia o serviço rapidamente. Ao ser mandado para a periferia, perguntava ao primeiro morador a quem entregasse o carnê, se conhecia fulano ou sicrano e eis que diante da resposta afirmativa pedia que lhes entregassem os respectivos carnês também, assim voltava cedo pra casa. Zena não sabe ao certo quando foi que Itamar parou de entregar os carnês de IPTU, mas associa esse momento ao que ela mesma parou de trabalhar, em 1986

80 No song book, vol.2, p.67, segundo a cronologia pesquisada por Luiz Chagas, Nego Dito ficou em $3^{\circ}$ lugar, e também segundo Fabio Giorgio (GIORGIO: 2005, p.122) e no livro sobre o Lira, Laerte Oliveira aponta que a música teria ficado em entre as primeiras colocações sem especificar qual a posição ou quem eram os outros vencedores. Arrigo fala na entrevista que a música ficou em $2^{\circ}$ lugar.
} 
Arrigo lembra que Itamar, já morando em São Paulo ia "de porta em porta" nas gravadoras (RCA Victor, e Copacabana) mostrar suas composições. Eles queriam que Itamar gravasse samba ou então pontos de umbanda. A intenção de transformar sua música em algo pasteurizado e industrializado deixava Itamar triste. Ele sempre saía das reuniões desanimado, segundo Arrigo. E Itamar confirma, na entrevista à Patrícia Palumbo, falando sobre a incursão pelas gravadoras:

Nem cinco músicas. Mas eu ia até as gravadoras, cantava uma música minha e ouvia: Olha faz um samba, você tem uma voz legal. Eu ficava puto sem entender nada. Isso aconteceu inúmeras vezes. Até que chegou um momento em que: Opa! Sabe o que é, você não está sabendo apresentar o negócio, não....(ASSUMPÇÃO apud PALUMBO: 2002, p.33)

Foi seu próprio senso crítico quem the disse isso. O significado de "saber" apresentar o trabalho, em sua fala, pode ser interpretado como sendo justamente a vestimenta da composição (arranjo) atrelado à maneira de execução (performance). A oportunidade de realizar uma temporada longa, com apresentações em vários dias seguidos, e num mesmo local era, e ainda é, rara. A Banda Isca de Polícia ${ }^{81}$, que foi formada para a gravação desse primeiro disco e para os primeiros shows de lançamento em 1981 passou a acompanhar Itamar.

Nesse sentido ressaltamos a questão da instituição de uma linguagem específica, da decantação de determinadas características musicais e cênicas, que a possibilidade do exercício regular (tanto de ensaios como de apresentações constantes) permite fazer amadurecer. Um show realizado num teatro, mesmo aquele com poucos recursos técnicos como o Lira Paulistana, difere daquele feito esporadicamente ao ar livre ou gravado para um programa de televisão. Itamar encenava o personagem Beleléu e os músicos

\footnotetext{
${ }^{81}$ A Banda Isca teve algumas formações, mas sempre contando com baixo, guitarra, bateria e vocais, e o acompanhou até o início dos anos 90. Pela Banda Isca passaram: Paulo Barnabé, Gigante Brasyl, Marquinhos Costa, Rondó, Luiz Chagas, Luiz Waack, Jean Trad, Tonho Penhasco, Luiz Lopes, Sergio Pamps, Skowa, Paulinho Lepetit, Bocato, Suzana Salles, Vânia Bastos, Virgínia Rosa, Denise Assumpção, Neusa Pinheiro, Alzira Espíndola, Tetê Espíndola, Tata Fernandes, Vange Milliet. A partir de 1992 Itamar formou as Orquídeas do Brasil, formada por mulheres instrumentistas: Alcione Ziolkowski, Simone Sou, Nina Blauth, Adriana Sanches, Georgia Branco, Miriam Maria, Lelena Anhaia, Clara Bastos, Tata Fernandes, Simone Julian, Renata Mattar.
} 
apresentavam-se com roupas de presidiário, enquanto o cenário simulava a cela de um cárcere, com cordas dependuradas.

O apelo aos recursos cênicos não é exclusividade de Itamar. De alguma maneira os principais grupos de canção que se apresentavam no Lira, entre 1980 e 1984, ou ligados à Vanguarda Paulista utilizavam-se da atuação e do humor (além daquele contido nas letras). Mas no caso de Itamar esses procedimentos passaram a ser prioritariamente explorados ao máximo para potencializar o efeito de suas canções, e eminentemente focados em sua figura $^{82}$, prática que nunca mais abandonou. Até nas gravações ele se ancora especialmente em aspectos interpretativos. Quando perguntei a Arrigo se ele considerava haver algum pré-requisito para que outros artistas interpretassem as canções de Itamar ele chamou atenção justamente para esse aspecto, o da necessidade de se buscar uma interpretação específica para cada música. Ele compunha pensando no fato de que era ele próprio quem iria cantar e atuar ${ }^{83}$. Para Arrigo, não seria adequado executar as canções de Itamar sendo apenas crooner. E explicou: "O intérprete inaugura um instante, o crooner apenas repete".

Com a banda Orquídeas do Brasil, lançou a trilogia Bicho de Sete Cabeças, em 1993, e escolheu um teatro público da prefeitura do município, o Teatro Martins Pena, no bairro da Penha em São Paulo, local onde pudesse realizar uma temporada longa, de quarta a domingo, durante um mês. Dessa maneira o show e a interpretação do repertório inédito teriam a oportunidade de amadurecer. Essa concepção lembra muito o que ocorre em teatro onde o resultado artístico atinge o auge depois dos participantes haverem exercitado e ampliado os limites da interpretação, e isso certamente não se dá na estreia, mesmo que se tenha ensaiado à exaustão. $O$ fator modificador dessa dinâmica é justamente o momento da recepção, quando há a presença do público. Discutimos aqui duas coisas distintas: primeiro a suposição de que Itamar finalmente decantou suas sínteses nesse período do Lira, havendo de fato

\footnotetext{
${ }^{82}$ Gerando sempre a dúvida de quem é quem: Itamar é o Beleléu ou vice-versa? No trabalho com as Orquídeas do Brasil o caráter das canções torna-se bem distinto. O enfoque na poesia tira a atenção sobre a demarcação de uma figura-personagem únicos. Mas o aspecto cênico jamais é abandonado.

${ }^{83}$ Opinião compartilhada por Alice Ruiz, em sua entrevista anexa.
} 
amadurecido como compositor. Teve que arranjar, gravar, e montar uma banda estável, além de interpretar ao vivo. Nessa temporada (antes da gravação ${ }^{84} \mathrm{e}$ nos shows de lançamento) encontrou uma maneira mais recorrente de atuar, e talvez mais definitiva. Em segundo lugar, apontamos a averiguação do tipo de performance, que ele veio a desenvolver, somada à ideia da composição, assunto que tratamos a partir de agora.

\subsection{PERFORMANCE E POETICIDADE}

Para refletir sobre a performatividade de Itamar utilizaremos como principal apoio os pensamentos de Paul Zumthor ${ }^{85}$. O autor, que foi medievalista, oferece um porto seguro para determinadas inquietações, não por apresentar fórmulas explicativas que pretendam liquidar problemas (e como consequência passarem a ser replicadas), mas por tocar com clareza e sensibilidade em fatores considerados subjetivos, e por isso de difícil abordagem, tais como os conceitos de poeticidade, de recepção, de performance, de ritual, do uso da voz, de cultura oral, de escritura. O trabalho de Itamar, independentemente de ser tratado como vinculado ou não à Vanguarda Paulista, certamente poderia ser visto pelo viés sociológico ${ }^{86}$. No entanto, dada a perspectiva lançada aqui, torna-se mais apropriada uma abordagem que priorize $o$ ato de fruição em si.

As reflexões de Zumthor também deixam em aberto o caminho para se discutir não só os conteúdos transmitidos pelas obras como também o modos de expressão possíveis, escolhidos pelo artista para que sua obra seja veiculada e compartilhada com outras pessoas. Considerando as produções

\footnotetext{
${ }^{84} \mathrm{Fez}$ vários shows na capital paulista e no interior do estado antes da gravação. $\mathrm{O}$ lançamento se deu num local chamado Paulicéia Desvairada, localizado no bairro do Itaim e também no Lira Paulistana.

${ }^{85}$ Nascido em Genebra em 1915 e falecido em Quebec, 1995.

${ }^{86}$ Estrela Ruiz aponta a possível proximidade da vanguarda paulista com a contracultura do final dos anos 70 (p.61); e Laerte de Oliveira, no decorrer de seu livro, associa os processos de Produção Independente verificado entre os artista aglutinados no Lira Paulistana, como sendo alternativos aos praticados pelas grandes gravadoras e os meios de comunicação de massa como a TV.
} 
artísticas midiatizadas ${ }^{87}$, isto é, realizadas diante e sob o aparato tecnológico que passou a estar disponível aos músicos, percebe-se o quanto esses meios de produção e veiculação passam a ser também constituintes das formas de expressão. Assim não haveria imposição econômica (mesmo que saibamos ter a música se tornado uma "mercadoria" e que as escolhas dos consumidores são dirigidas pela indústria) que pudesse explicar os profundos significados e transformações que determinadas obras ou acontecimentos artísticos geram nos indivíduos. Parece-nos mais adequada, portanto, no caso da obra de Itamar, uma visão que contemple esses fatores, e que considere as formas de expressão também como parte do conteúdo.

\section{Corporalidade, voz e rito em Itamar.}

Na perspectiva de Paul Zumthor existe o forte entrelaçamento entre os conceitos de voz, performance, poeticidade, recepção, ritual, aos quais trata com profundidade, submetendo-os a diversos períodos históricos, ampliando e atualizando seus sentidos. E por se tratar de um referencial teórico amplo, com aplicabilidade em diversas áreas de conhecimento, reunimos aqui apenas alguns dos aspectos detectados como sendo pertinentes à obra de Itamar, aqueles que podem auxiliar a enxergá-la.

Ao falar sobre poesia, Zumthor propõe o conceito de poeticidade. A poeticidade seria uma condição que se alcança, um estado. Seria uma situação com propriedade de agregar a condição de expressão tanto do objeto poético como do receptor ${ }^{88}$ ou expectador.

A poesia, no impulso primeiro que a compele à existência, é anterior à linguagem. Vamos nos fazer entender: nas fases sucessivas que ritmam

\footnotetext{
${ }^{87}$ Discorrendo sobre os tipos de mídia existentes, Norval Baitello Júnior remete-se a Harry Pross quando este considera que a mídia primária é o próprio corpo. No texto $O$ Tempo Lento e o Espaço Nulo -- mídia primária, secundária e terciária, afirma que, desde que se efetive qualquer tipo comunicação, o corpo seria a mídia primeira, tanto a que gera como a que recebe a informação.

${ }^{88}$ Sobre a utilização do termo "recepção" fica aqui a ressalva, dado o fato de que os estudos sobre performance, ou Performance Studies, que tentam contemplar a performance nas artes em geral, se opõem a ideia de passividade do expectador. Esses estudos ganharam autonomia nas últimas décadas tendo como pioneiro Richard Schechner (STOROLLI, p.32, 2009). Sendo assim haveria um papel ativo, gerador de interação, mesmo que essa ação não esteja visível em uma atitude corporal ou verbal direta do público. Essa visão é também claramente compartilhada por Zumthor em suas reflexões. No entanto a utilização da palavra "recepção" pode gerar esse equívoco.
} 
este impulso, a poesia encontra a linguagem, mas, ela atravessa, às vezes passando para o outro lado, ou uma se casa com a outra, transforma-a e é transformada por ela. A despeito da diversidade dessas colocações, podemos afirmar, por paradoxo, que não existe laço exclusivo, nem mesmo absolutamente necessário, entre poesia e linguagem. (ZUMTHOR: 2005, p.139)

Há outra coisa que atravessa a linguagem, para Zumthor. Algo que possui materialidade e que também é anterior à linguagem, que provém do corpo, mas que não pertence a ele: trata-se da voz. A voz, apesar de não ser o corpo, quando ouvida traz o sentido da presencialidade e da corporalidade de alguém. Ou seja, sua escuta nos remete à existência, seja à nossa própria, à do outro ou de ambos, antes de qualquer fato. Significa a presença da existência de um corpo vivo.

A poeticidade, e aquilo que é poético, podem acontecer em qualquer lugar ou objeto. Em princípio denominamos, de modo geral, a poesia como sendo parte da literatura e para Zumthor como sendo, de algum modo, a ritualização da linguagem. Mas nesse fato ele vê "uma convergência profunda entre performance e poesia, na medida em que ambas aspiram à qualidade de rito" (ZUMTHOR: 2000, p.53). E o rito, entendido por ele, sem necessariamente conter a conotação sacra. A atribuição desse senso de poeticidade é dada pela relação que se estabelece no momento da recepção entre aquele que frui e a fonte que lhe comunica. O momento da recepção coincide como o momento da percepção. Desde a leitura solitária de um poema até um show ou concerto onde outros compartilharão do mesmo espaço e tempo. A voz também estará presente, pois no mínimo será a própria voz interna, que lê o texto "em silêncio" (no caso do poema), ou a voz do outro que tomamos como nossa. Quando o cantor "fala" em primeira pessoa, se estabelece um enunciado no qual o "eu" nele expresso é tomado como próprio por quem o recebe.

[...] quando o cantor emprega o "eu", a função espetacular da performance confere a esse pronome pessoal uma ambiguidade que 0 dilui na consciência do ouvinte: "eu" é ele, que canta ou recita, mas sou eu, somos nós; produz-se uma impessoalização da palavra que permite àquele que a escuta captar muito facilmente por conta própria aquilo que 0 outro canta na primeira pessoa. $O$ poder identificador (se assim posso nomeá-lo) da performance é infinitamente maior do que o da escrita. (ZUMTHOR: 2005, p.93) 
Para Luiz Tatit ${ }^{89}$ a obra de Itamar possui um aspecto bem específico que é a identificação de um "eu" imenso criado por ele, dentro dos limites da canção, na primeira fase de suas composições. Esse "eu", o enunciador, é quem nos faria supor que Itamar é Beleléu, pela maneira intensamente comprometida e identificada com o conteúdo que sugere na maneira de dizer. Alguém que se expressa no exato momento em que canta. Se considerarmos essas colocações, é possível reforçar ainda mais o caráter incisivo de sua performance.

Quando Zumthor fala sobre o "impulso primeiro que compele à existência", aproxima-se da questão do ritual e da necessidade permanente que o ser humano tem de criar maneiras para enfrentar sua condição de finitude, de entender a morte. O discurso poético, para ele, tenderia a tocar no que é essencial, "[...] porque o essencial é estancar a hemorragia de energia vital que é o tempo para nós" (ZUMTHOR: 2000, p.61). Os rituais sempre estiveram ligados ao sagrado, mas não é necessário que seja assim. No entanto a questão do fim da existência está sempre presente.

No caso do ritual propriamente dito, incontestavelmente, um discurso poético é pronunciado, mas esse discurso se dirige, talvez, por intermédio dos participantes do rito, aos poderes sagrados que regem a vida; no caso da poesia, o discurso se dirige à comunidade humana: diferença de finalidade, diferença de destinatário; mas não diferença da própria natureza discursiva [...] (ZUMTHOR: 2000, p.54).

Hoje eu tenderia a explicar o conjunto de caracteres poéticos pela relação com a percepção e apreensão do tempo. A linguagem em sua função comunicativa e representativa insere-se no tempo biológico, que ela manifesta e assume, sendo assumida por ele, e sem ter sobre ele algum poder, incapaz de aboli-lo, e em contraparte destinada a dissipar-se nele. A prática poética se situa no prolongamento de um esforço primordial para emancipar a linguagem (então, virtualmente o sujeito e suas emoções, suas imaginações, comportamentos) desse tempo biológico. Esse esforço se realiza de forma diferente, segundo os contextos culturais; pelo menos aí percebemos sempre essa vontade às vezes cega, mas radical, essa energia vital presente nos começos de nossa espécie e que luta em nós para roubar nossas palavras à fugacidade do tempo que as devora. Pouco importa saber aqui se esse esforço pode ou não chegar ao fim; o que conta é que, nesse esforço desperta uma consciência e se formaliza o ritual, que ele funda e irriga com sua energia. (ZUMTHOR: 2000, p.57)

89 Compositor, membro no Grupo Rumo, em seu texto no song book, (TATIT apud ASSUMPÇÃO: 2006, Vol. 1, p.21) 
Essa suposta possibilidade de "superação" do tempo biológico é vista também por Mircea Eliade (ELIADE: 1986, p.152) quando fala sobre o fato de que alguns aspectos e funções do pensamento mítico são constitutivos do ser humano e que perduram no mundo moderno tal como o "regresso às origens". Desta maneira os ritos encenariam os mitos.

Ao apontar a dimensão performativa da voz, Wania Storolli (STOROLLI: 2011, p.7) destaca uma fala de Meredith Monk: "A voz - o instrumento original pode delinear sentimentos e estados de ser, de modo que a música pode ser experienciada diretamente por qualquer um. Desta forma, é transcultural e tem um sentido de ausência de tempo..." (MONK: 2002, p.23). Essa visão pode ser entendida tanto como a afirmação de que a voz (desatrelada da língua) gera a sensação de justaposição de contemporaneidade com antiguidade, tal como interpreta Storolli, bem como percebê-la como geradora da sensação de que o tempo não existe, inserindo-nos no "não-tempo".

Assim a performance seria uma espécie de catalisador para a criação de determinadas condições, onde alguns tipos de rito podem se efetuar. Daí que Zumthor considere o termo como antropológico e não como histórico, referindose a um momento tomado como presente. A comunicação poética efetuada pela performance, mais do que ter como finalidade a transmissão de conteúdos de conhecimento e de informação, gera transformações em quem a recebe ou a compartilha.

Citando Dell Humes ${ }^{90}$, Zumthor coloca a performance como sendo a emergência de algo que somos capazes de reconhecer, e que passa da condição de virtualidade à de atualidade. Possui a qualidade de "reiterabilidade" sem ser, no entanto, sentida como redundante. Definir performance segundo as diversas perspectivas existentes gera algumas implicações dependendo do que se queira abordar. Zumthor se refere mais diretamente à poesia como texto de literatura, relacionando-a a oralidade, e em seus livros ${ }^{91}$ pontua essas circunstâncias. Mas ao mesmo tempo valida o intuito de uso que pretendemos fazer aqui, de encontrar meios de abordar a maneira

\footnotetext{
${ }^{90}$ Breakthrogh into Performance, nos Cadernos de Trabalho do Centro de Semiótica de Urbino, oㅗs 26-27, 1973.

${ }^{11}$ Introdução à Poesia Oral; Performance, Recepção e Leitura; Escritura e Nomadismo.
} 
como Itamar Assumpção apresentava suas músicas ao vivo e nas gravações, atuando e interpretando. A performance, em sua definição geral "se refere de modo imediato a um acontecimento oral e gestual" (ZUMTHOR: 2000 p.45).

A ideia da presença de um corpo implica em que ele seja considerado ao se efetuar o estudo de uma obra. Ao mesmo tempo, "a performance não apenas se liga ao corpo, mas, por ele, ao espaço. Esse laço se valoriza por uma noção, a de teatralidade [...]" (ZUMTHOR: 2000, p.47). Baseando-se num artigo de Josette Féral ${ }^{92}$, Zumthor ainda aponta que um dos aspectos que mais conta é o reconhecimento de um "espaço de ficção" (idem). Assim quando o público adentra na sala de teatro (onde ocorrerá um show, um concerto ou uma peça), já está naturalmente compactuando e se predispondo ao evento que ocorrerá ali. A iluminação, as cortinas, a disposição dos instrumentos (ainda inanimados), o cenário, ajudam a criar essa atmosfera e expectativa. Com o início do espetáculo e a entrada do(s) músico(s), do(s) cantor (res) ou do(s) ator (res) esse espaço cênico se efetiva e as dimensões do estado ficcional vão sendo controlados e aprofundados pela dinâmica que se estabelece entre a performance e a recepção.

No caso de Itamar isso é evidente. Nos primeiros shows ${ }^{93}$, havia uma contundência, desencadeada pela sonoridade das composições e dos arranjos, amplificada por sua presença física e gestual. Num desses shows, o cenário simulando uma cela (conforme já descrevemos), apenas com a sugestão de cordas dependuradas, criava o paradoxo entre o som que explodia, emergido do palco, e a parca contenção que aquelas grades poderiam oferecer. Há dezenas de exemplos que podem ser descritos. Mostraremos alguns específicos quando chegarmos ao momento das análises, para aprofundá-las. Mas é importante frisar que existem diversos graus de performatividade que podem ser encontrados e verificados. Ao mesmo tempo em que, para Zumthor, a mediação tecnológica (capaz de fixar a voz e a imagem) abole o caráter de

\footnotetext{
92 Publicado em 1988 na revista Poétique.

${ }^{93}$ Mostrados, em gravações raras, no recente documentário produzido pelo Instituto Itaú Cultural (da série Iconoclássicos) e dirigido por Rogério Velloso, intitulado Daquele Instante em Diante, de 2011. Em especial o show intitulado Vertigem, uma mostra que ocorreu no teatro Bandeirantes em São Paulo e que reuniu artistas da Vanguarda, Arrigo, Premê, Rumo e Itamar.
} 
efemeridade da performance, tirando o que ele chama de "tactilidade" $"$, em determinados momentos alguns desses registros podem até amplificar detalhes que passariam despercebidos pelo público, tais como um gesto menor ou um olhar sob os óculos escuros.

Verifica-se que no início da vida artística de Itamar há muito mais empenho em gestos corporais amplificados (lembrando-se de toda sua vivência da cultura negra, descrita anteriormente, que é bastante corporal por natureza). Esses gestos tenderam a ser diminuídos gradualmente, não só pela passagem da juventude para a maturidade, e da saúde para a doença, mas também pela concisão de linguagem e de expressão que Itamar foi adquirindo e optando em utilizar.

Destacamos dois exemplos, a seguir, da mesma canção Anteontem Melô da U.T.I $)^{95}$, que demonstram a performatividade de Itamar tanto no palco como em estúdio. Qualquer observação que for feita a respeito destes exemplos está, evidentemente, sujeita à subjetividade enquanto recepção da mensagem poética. O mesmo ocorreria diante de qualquer obra ou performance, em relação à descrição de como nos parece ser o sentimento de poeticidade e no que ele resulta. Nesse sentido Zumthor afirma que "nossa percepção do real é frequentada pelo conhecimento virtual, resultante da acumulação memorial do corpo" (ZUMTHOR: 2000, p.96). Os sentidos, tais como a visão e a audição, não seriam então somente ferramentas de registro, mas "órgãos de conhecimento" (p.95). De qualquer forma a característica performática está presente, independentemente do grau ou do tipo de poeticidade que se possa atribuir.

\footnotetext{
${ }^{94}$ A fixação e a reprodutibilidade permitem a constante reiteração de uma imagem ou música, tornando-as por isso elementos abstratos, desvinculados do momento ritualizado. Como se sabe, desde as publicações de Michel Chion, a possibilidade de gravação do som separa 0 ouvinte ou o expectador da fonte sonora, e portanto o distancia dela no tempo e no espaço. Murray Schafer chama esse fenômeno de esquizofonia.

${ }^{95}$ Anexos 6 e 5, respectivamente DVD (faixa única, segunda música) e CD (faixa 10). São gravações de duas versões da mesma canção: uma performance ao vivo (num show realizado em 2002 no teatro Itaú Cultural) e outro no áudio do CD Pretobrás III, pertencente à Caixa Preta finalizado postumamente, lançado pelo Sesc São Paulo em 2010.
} 
Anteontem, Melô da U.T.I., registro de show.

O poema Anteontem, ou Melô da U.T.I., (fig.10) foi primeiro apresentado declamado ao vivo, depois foi musicado pelo próprio Itamar num disco. A letra diz:

\begin{tabular}{|c|c|}
\hline $\begin{array}{c}\text { Poema recitado e encenado em show, } \\
\text { com a participação de Elke Maravilha no } \\
\text { papel de Morte }\end{array}$ & $\begin{array}{l}\text { Poema da canção Anteontem (melô da } \\
\text { U.T.I) do CD Pretobrás III, com } \\
\text { pequenas diferenças de texto. }\end{array}$ \\
\hline Hoje eu estou aqui & Hoje eu estou aqui \\
\hline Por ser forte e por ter sorte & Por sorte não por ser forte \\
\hline Da equipe do bisturi & Porque que sobrevivi não sei \\
\hline Saber pra que serve dote & Sei que não foi blefe ou trote \\
\hline Seis vezes na UTI & Anteontem na U.T.I. \\
\hline Seis vezes visitou-me a morte & Foi me visitar a morte \\
\hline Mesmo sedado senti & Mesmo sedado senti \\
\hline Seu bafo no meu cangote & Seu bafo no meu cangote \\
\hline De susto quase morri & De susto quase morri \\
\hline Deu pânico entrei em choque & Deu pânico entrei em choque \\
\hline Quando nas mãos dela eu vi & Quando nas mãos dela eu vi \\
\hline Em vez de foice, serrote. & Em vez de foice, serrote. \\
\hline Me disse: eu só vim te advertir & Disse: vim te advertir \\
\hline Somente te dar um toque & Somente pra dar uns toques \\
\hline Inútil tentar fugir & Burrice tentar fugir \\
\hline Cuide-se bem, se comporte. & Cuide-se bem, se comporte. \\
\hline Daí desandou a rir & Aí desandou a rir \\
\hline Do cateter, rir dos cortes. & Do cateter, rir do corte. \\
\hline Passou a se divertir & Passou a se divertir \\
\hline
\end{tabular}




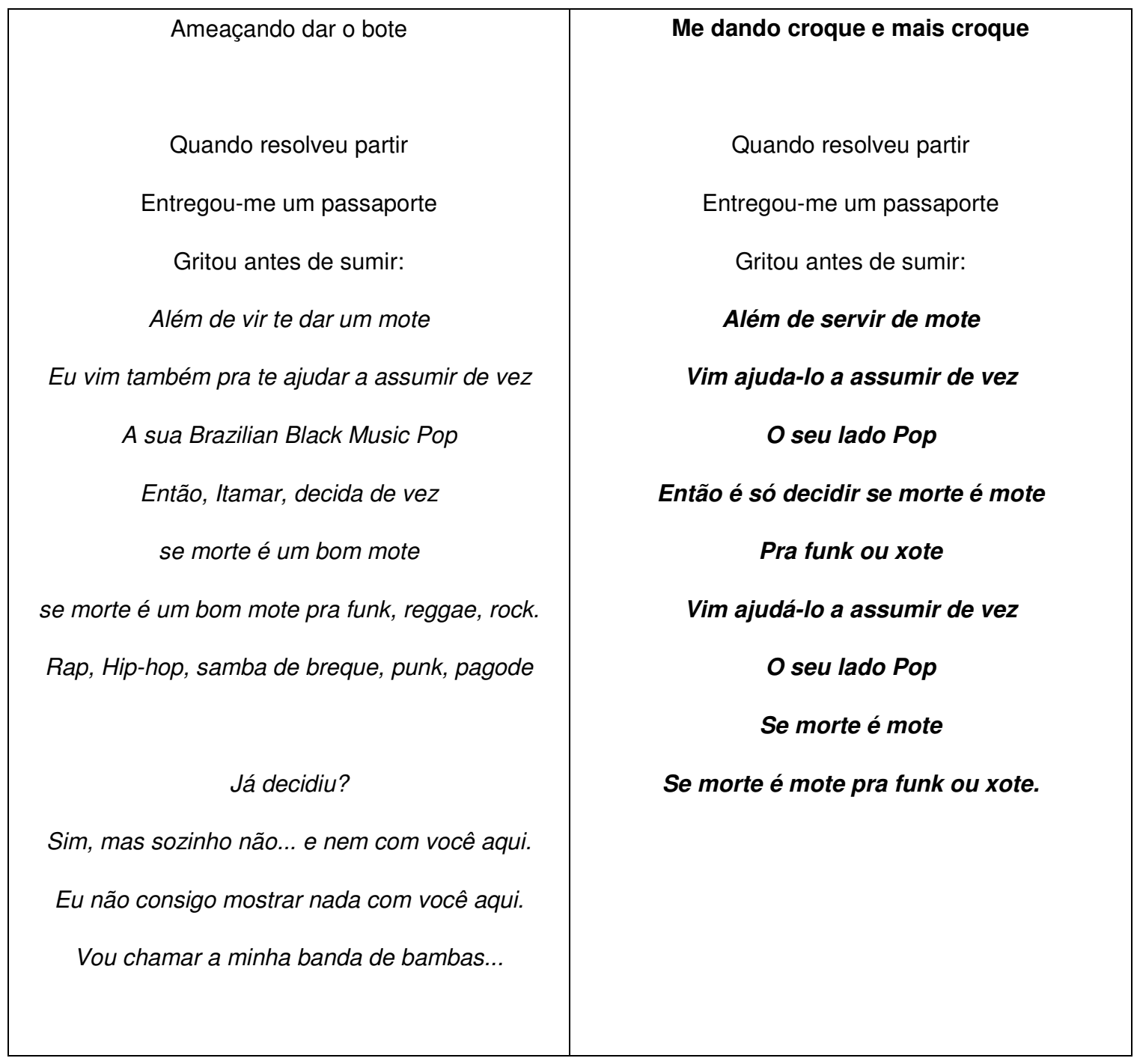

Fig. 10: Melô da U.T.I., duas versões da mesma música, a primeira de show (DVD anexo faixa única e CD anexo faixa 10)

Por coincidência há nesse poema uma questão biográfica real presente e bastante explicita, o que não necessariamente era de seu hábito, embora em muitas situações possa haver dúvida para o espectador quanto a isso. Já nos referimos aqui ao fato de que se costuma confundir o que o próprio Itamar dizia ou fazia no palco e nas gravações com o que ele era de fato no dia a dia. $\mathrm{Na}$ obra de Itamar esses elementos foram misturados propositalmente ${ }^{96}$, justamente reforçando a observação de Luiz Tatit da grande identificação entre aquele que diz as palavras e o conteúdo delas. Isso traz uma verossimilhança

\footnotetext{
${ }^{96}$ Até pela maneira intensa como ele vivia a música. Dormia poucas horas por noite e dedicava grande parte de seu tempo a composição e a reflexão. Então, de algum modo, essa mistura entre a hora de estar no palco e sua vida cotidiana de fato não eram tomadas por ele como momentos tão distintos um do outro.
} 
maior, tornando a situação mais convincente ao ouvinte embora ele saiba, evidentemente, de que se trata de uma representação.

Aqui nesse exemplo escolhido não se trata de qualquer fato trivial, é a reelaboração de seu próprio enfrentamento à morte (coincidência também com a questão do rito). Mas ao mesmo tempo, ela está personificada na pessoa (personagem) de Elke Maravilha ${ }^{97}$, e isso dá de imediato um caráter ficcional e de humor. A morte só aparece pra falar sobre o Itamar compositor. Ela não vem para levá-lo embora, pelo menos naquele instante, mas deixa com ele um passaporte para que isso seja possível num outro momento. Ou seja, não é qualquer um, a qualquer hora, que estaria habilitado a realizar a viagem. Vem para lembrá-lo do dilema que sempre carregou, o da busca pelo novo. Vem para ajudá-lo a assumir as características "pop", que ele parece ter em suas composições, mas sobre as quais apresenta dificuldades em "adotar" de vez.

À parte do conteúdo do poema, a performatividade está presente de maneira contundente nas duas gravações. As duas versões apresentam diferenças em vários trechos dos versos. Itamar as adequou em função do veículo em que iriam ser reportadas. No show preparou-se para estar presente ao vivo, independentemente da gravação em DVD, pensando em toda a sequência do espetáculo. No $C D$, além da junção com uma melodia (que estava ausente no show) preparou entonações de voz que pudessem remeter ao estado tenso de diálogo com a visita inesperada. A morte, nesse caso é "encenada" pelas conhecidas vozes femininas, que 0 interpelam constantemente em muitas das composições.

(1) No vídeo: É o início do show. A voz de Elke anuncia:

\footnotetext{
${ }^{97}$ Elke é atriz, de origem russa, nascida em 1945. Chegou ao Brasil com 6 anos de idade, foi modelo e participou de vários filmes. Fala nove línguas e durante anos participou como jurada do programa televisivo de Silvio Santos, onde ficou conhecida popularmente. Apesar de afastada da televisão ainda é muito querida e abordada. Itamar a convidou para participar de alguns shows, entre eles esse ocorrido no teatro do Instituto Itaú Cultural, em São Paulo. Elke também foi homenageada por Itamar numa canção dedicada à ela, que consta do CD Pretobrás 1 .
} 
"São Paulo, 03 de agosto de 2002, 19h30'98. Após algumas expectativas hospitalares, direto da Avenida Paulista, uma gentileza do Instituto Itaú Cultural, daremos início ao programa Rei da Cocada Preta. Com vocês: Itamar Assumpção!"

Itamar canta à capela Dor Elegante ${ }^{99}$ (DVD anexo faixa única e CD anexo faixa 11), a parceria com Paulo Leminski:

Um homem com uma dor

É muito mais elegante

Caminha assim de lado

Como se chegasse atrasado

Andasse mais adiante

Carrega o peso da dor

Como se portasse medalhas

Uma coroa, um milhão de dólares

Ou coisa que os valha

Ópios edens analgésicos,

Não me toquem nessa dor

Ela é tudo o que me sobra

Sofrer vai ser a minha última obra

Ela é tudo o que me sobra

Viver vai ser a nossa última obra

\footnotetext{
${ }^{98}$ Tal como ocorre na gravação ao vivo do disco Às Próprias Custas S.A., de 1983. Denise Assunção tem uma fala inicial, dizendo um texto de introdução, situando o evento num tempo e lugar "reais". Diz que se trata de um programa de rádio, chamado Mais lenha Nesse Inferno, e pelas características improváveis da fala marca, ao mesmo tempo, um espaço ficcional.

${ }_{99}$ Foi gravada somente em 1998 no primeiro volume da série Pretobrás, com a participação de Zélia Duncan.
} 
A ausência de acompanhamento instrumental faz voltar a atenção sobre o poema. Essa canção foi executada ao vivo muitas vezes durante sua carreira mas nesse momento estratégico (no início do espetáculo) é utilizada para reforçar o aspecto biográfico (em princípio os ouvintes sabem que ele está ou esteve doente). Nota-se a precisão rítmica da execução. Entre os versos das estrofes e entre as estrofes há até dois compassos de pausa para a melodia ser retomada, num andamento lento. $O$ ouvinte pode perceber esse silêncio pulsando, através dos gestos que faz, sem que esses gestos estejam necessariamente marcando $o$ andamento.

Ele prossegue, com a Anteontem - Melô da UTI, dizendo que nem na maca teve sossego, já que tinha muito trabalho a fazer, compondo e inventando. O poema é então declamado, tal como um depoimento. Ele está sentado, quando uma figura se aproxima, é a morte, que ele sente como um "bafo no cangote". Sussurra para dizê-lo, pianíssimo. "De susto quase morri, de pânico entrei em choque", fala simulando medo na voz sem, no entanto, crescer a dinâmica. A morte ri: Já decidiu (se morte é um bom mote para compor)? Pode-se ver de leve o olhar assustado, sob os óculos escuros (que são sua marca, sua máscara). "Sim, mas não sozinho e nem com você aqui" reponde Itamar, e segue com o show. Quando, mais adiante no show, chega ao fim da música de Jards Macalé, chamada Costura (cujo refrão diz: costura meu amor costura, com linha pura meu amor com o seu...) tece ainda mais um comentário sobre a própria cirurgia, a qual havia sido recém submetido: "os caras de corte e costura não são brincadeira não!"

Paul Zumthor, extraindo algumas teses a respeito da voz ${ }^{100}$, afirma que "todo objeto adquire uma dimensão simbólica quando é vocalizado". Assim, como nesse exemplo de performance descrito e que utiliza a voz como centro da ação, ocorre uma espécie de concretização, de algo que reconhecemos mas que se encontrava em estado de virtualidade. Diz Zumthor (ZUMTHOR: 2000, p.36 e 37), baseando-se em Hymes, que a performance seria uma "conduta na qual $o$ sujeito assume aberta $e$ funcionalmente a

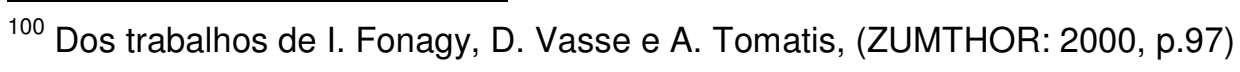


responsabilidade". O conhecimento não é simplesmente transmitido pela performance, pois não é sua função. Mas ela o marca e o transforma. Observase ainda, no exemplo escolhido aqui, a "reiterabilidade" de alguns assuntos (a situação da doença, das cirurgias, do contato como a morte). Essa repetição poderia ser identificada, em outras situações, como elementos musicais de uma composição, ou as rimas de um poema, e ainda a semelhança entre as cores de uma série de quadros. Mas faz parte da performance a repetitividade, a reiteração que não é percebida como redundante. Trata-se de aspectos do conhecimento sendo marcados e transformados através da escolha da maneira como será abordado.

(2) Anteontem - Melô da UTI, canção do CD Pretobrás III.

Nessa gravação, originalmente realizada com a voz e o violão ${ }^{101}$ de Itamar, o arranjo e a instrumentação foram acrescidos posteriormente. Paulinho Le Petit, contrabaixista e arranjador, foi responsável pela produção desse disco e do CD chamado Isso Vai Dar Repercussão, de Itamar em parceria como Naná Vasconcelos. Para Lepetit ${ }^{102}$, a maneira como Itamar tocava violão e cantava já continha informações musicais ricas. Em sua entrevista afirma que a maioria das ideias musicais presentes nos arranjos que efetuou, sem a presença de Itamar, já estavam contidas na maneira dele interpretar. As informações musicais foram apenas extraídas, ampliadas, e distribuídas para outros instrumentos. Para Paulinho, conforme já havíamos dito, em muitas das gravações, o excesso de informação acabava acobertando as sutilezas que a maneira de tocar e interpretar que Itamar tinha. Nos trabalhos póstumos tentou deixar esse aspecto em evidência, mantendo em vários momentos somente o violão e a voz. Uma maneira interessante de valorizar a obra do artista, tal como uma restauração que deixa em evidência as partes antigas intactas, mesmo que incompletas, misturando-as com a utilização de materiais modernos que reforçam sua estrutura.

101 Assim como todas as canções dos CDs Pretobrás II e III, cuja finalização foi feita postumamente, partindo sempre de gravação de violão e voz que Itamar deixou espalhadas em alguns estúdios de amigos.

${ }^{102}$ Em entrevista (anexo 4) 
Voltando à canção, temos então o fato de que ao poema foram acrescidos melodia e acompanhamento. O poema foi modificado. Não temos como saber exatamente o porquê. A melodia é sempre reapresentada com a mudança das estrofes. Há, nesta canção uma preocupação com a clareza da dicção. Esse é um cuidado constante que pode ser observado em toda a obra de Itamar. Talvez a experiência com teatro possa ter the apontado como realizar tecnicamente o uso da voz, de modo a tornar clara a pronúncia das palavras e fazê-las inteligíveis, nas diversas situações de amplificação e mediação. Esse é mais um fator de identificação do ouvinte com o enunciador, pois a pronúncia cuidada destaca as palavras e chama a atenção para a maneira como cada uma delas está sendo dita. A fala da morte fica dividida entre o vocal feminino e a enunciação realizada pelo próprio Itamar, numa mesma altura (uma nota aguda) cantada, como se estivesse imitando sua fala.

O fato de ser repetitiva the da um caráter incisivo, tal como a mensagem que ela tem para comunicar. A morte quer saber se é mote para as composições de Itamar, se é mote para funk ou xote, e quer que ele the responda. Então o lado "pop" que a morte the reivindica aparece, metalinguisticamente na própria composição, acentuado no refrão:

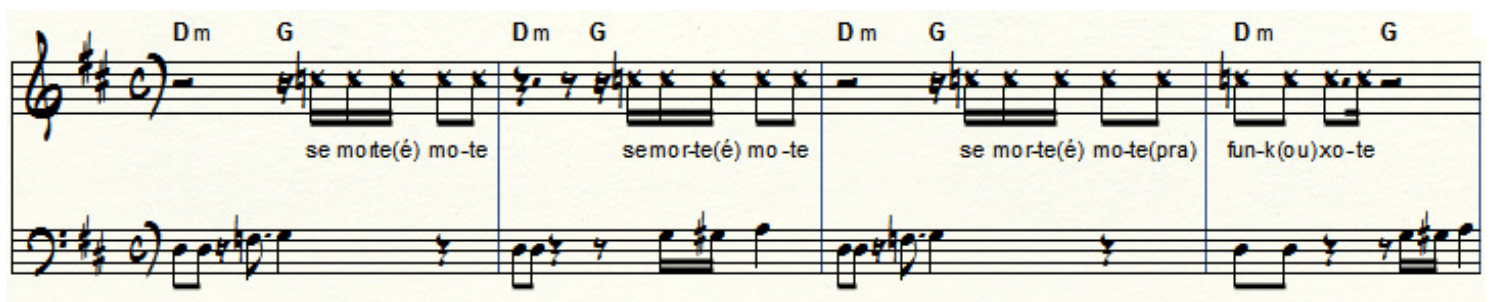

Fig. 11: Anteontem, refrão. Tonalidade de ré maior. Refrão em ré menor.

(CD anexo faixa 10)

Há aqui a frequente brincadeira rítmica, sempre sugerida por Itamar, e que é encampada pelo arranjo. Observações sobre a performance seguirão sendo feitas durante as análises das músicas escolhidas. Antes de iniciarmos o segundo capítulo façamos as últimas observações que dizem respeito à formação musical e artística de Itamar. 


\subsection{TROPICALISMO NA TEIA DA VANGUARDA PAULISTA}

Como observa Luiz Tatit no prefácio da $3^{\text {a }}$ edição do livro Tropicália Alegoria Alegria, de Celso Favaretto:

O tropicalismo deixou estilhaços em diversos lugares da cultura brasileira e, à medida que o tempo passa descobrem-se fragmentos que ainda fervilham e geram novos focos de criação de alguma forma tributários daquele final dos anos 60. (TATIT in FAVARETTO: 2000, p.11).

É interessante notar que esse importante estudo realizado por Favaretto data de 1979. São os ecos da Tropicália interessando ao meio acadêmico muito pouco tempo depois da deflagração do movimento. O compositor e professor Luiz Tatit, que pertencia ao grupo Rumo e que escreve o texto de apresentação para o livro, em 1995, fez parte da Vanguarda Paulista. O teatro Lira Paulistana foi inaugurado também em 1979. Enquanto esse estudo era escrito Tatit, junto com Arrigo Barnabé, Itamar Assumpção, Premeditando o Breque, Língua de Trapo e outros artistas, estavam no início de efervescência de suas carreiras.

Alguns desses importantes experimentalismos ocorridos na história da música popular urbana acabaram se efetuando em São Paulo (inclusive o Tropicalismo) e cronologicamente vem na sequência dos discos da Tropicália. As canções compostas por Arrigo e Itamar, por exemplo, são da década de 70, como já foi dito, e começaram a ser gravadas e veiculadas a partir dos anos 80. Laerte Fernandes de Oliveira destaca em seu livro sobre o Lira Paulistana trecho da entrevista de Arrigo Barnabé à revista Veja, em 1982:

\footnotetext{
Eu sou filho da Tropicália. Sem ela eu não existiria. Na época eu ouvia as músicas de Caetano e Gil e ficava me perguntando: se eles faziam inovações nas letras e no arranjo, porque não faziam na música também? Porque não alteravam os compassos, por exemplo? [...] (BARNABÉ apud OLIVEIRA: 2002, p.64).
}

A respeito da possível relação entre Tropicalismo e Vanguarda Paulista, e da pessoa de Itamar Assumpção, o compositor Gilberto Gil fala, em seu depoimento para o song book Pretobrás: 


\begin{abstract}
Em Itamar havia uma certa...uma máscara, digamos assim, um kabuki, o anjo torto. Uma oscilação entre o querer ser popular, de trabalhar com a canção ligeira que faz sucesso no rádio e é querida da dona de casa, e o não querer. E ela acabava escondendo os outros aspectos, como a vontade de ser ouvido. O tropicalismo expôs claramente isso, constituiu um espaço onde essas dimensões dialogavam, onde havia todas essas polarizações, fácil-difícil, comercial-hermético. O que acho que eles (referindo-se a Arrigo e Itamar) conseguiram foi partir de certos elementos embrionários de experimentalismo da tropicália e seguir em diante. Formaram uma mater, uma matriz ampla de trabalho. (GIL apud ASSUMPÇÃO: 2006, vol.2,p.23)
\end{abstract}

Embora Gil não tenha tido relações pessoais ou artísticas com Itamar, fez essas interessantes observações que talvez não fossem possíveis de serem percebidas ou ditas pelas pessoas mais próximas. "Se estivesse vivo, poderia fazer muita coisa, talvez escolhendo, se conformando um pouco mais em não ser tudo", completa. Itamar se queixava discretamente por não ter a atenção direta dos artistas da Tropicália, o que talvez pensasse ser natural que ocorresse $^{103}$, muito embora não se referisse ao Tropicalismo como tendo sido influente sobre sua maneira de pensar.

A despeito das diferenças estéticas entre os membros da Vanguarda Paulista, fato que no fundo Ihes tirava o caráter de unidade no movimento, havia a preocupação com o novo, em obter a inovação estética de alguma maneira. Estrela Ruiz (LEMINSKI: 2011, p.38), em seu estudo aponta como traços comuns entre os artistas da Vanguarda a utilização do texto na música de uma maneira diferenciada dando-se grande importância às letras e à performance. Então, se há algum aspecto que pode ser identificado como comum, entre Vanguarda e Tropicalismo, está a preocupação estética de ruptura. No entanto uma série de feitos foram realizados anteriormente pelo Tropicalismo, que permitiram à Vanguarda experimentar outras questões. Favaretto aponta precisamente o impacto dessas mudanças sobre a então canção urbana.

O Tropicalismo elaborou uma nova linguagem da canção, exigindo que se reformulassem os critérios de sua apreciação, até então determinados pelo enfoque da crítica literária. Pode-se dizer que o Tropicalismo realizou no Brasil a autonomia da canção, estabelecendo-a como um objeto enfim reconhecível como verdadeiramente artístico. (FAVARETTO: 2000, p.32)

${ }^{103}$ A canção de Caetano Veloso "Língua", do disco Velô, cita Arrigo Barnabé. 
Esse papel poderia ser atribuído também à Bossa Nova. Ambos os movimentos contribuíram ainda mais para que se estabelecesse o amálgama entre música e poesia, e sobretudo o Tropicalismo, uma vez que a composição passou a agregar também fortes e diferentes códigos estéticos. Aliada à canção, e isto sim parece ter sido sua contribuição direta, passaram a estar presentes elementos novos de arranjo, de interpretação vocal e de performance. Favaretto cita a presença da guitarra elétrica em "Alegria, Alegria" e "Domingo no Parque" 104 que causou protestos veementes. Para um dos arranjadores da Tropicália, Rogério Duprat ${ }^{105}$ "o uso da guitarra não era um negócio puramente musical e sim um novo tipo de comportamento pop, que vinha envolvendo o mundo desde 1960". Não se queria ofender ninguém, era apenas experimentação. À parte o aprofundamento que o estudo de Favaretto oferece sobre o movimento, para este estudo basta-nos observar, no momento, uma mudança de paradigma que favoreceu à Vanguarda Paulista: o fato de que aquilo que se diz passar poder estar subordinado à maneira como se diz.

É interessante notar a presença de dois músicos e maestros, Rogério Duprat e Júlio Medaglia, tanto diretamente nos trabalhos da Tropicália, como indiretamente nos trabalhos da Vanguarda Paulista. Para as composições de Caetano e Gil, Duprat e Medaglia escreveram arranjos. Duprat, especialmente tinha proximidade com música aleatória, concreta e eletrônica, ou seja, com a vanguarda da música erudita. Em relação à Vanguarda Paulista, mais diretamente aos nomes de Arrigo Barnabé e Itamar Assumpção seu papel foi discreto, mas considerado importante por ambos. Duprat ofereceu seu estúdio para que gravassem suas composições, conforme já foi dito, antes dos anos 80.

Disponibilizando o espaço estava naturalmente avalizando sua qualidade. Cada um gravaria cerca de três músicas, no entanto essas gravações não tiveram resultado direto, pois não geraram um disco, mas auxiliaram a ambos no amadurecimento de seus trabalhos. Principalmente no caso de Itamar, conforme relato de Paulo Barnabé, em que as diversas horas

\footnotetext{
${ }^{104}$ Respectivamente as canções de Caetano Veloso e Gilberto Gil.

${ }^{105} \mathrm{Em}$ entrevista destacada no livro (FAVARETTO: 2000, p.46).
} 
de estúdio disponibilizadas permitiram o exercício prático de arranjo, somado ao exercício da escuta de seus resultados. Sobre seu modo de compor e o contato com Duprat Itamar falou à Patrícia Palumbo:

Já cheguei assim. Quem me disse isso, de maneira até bem humorada, foi Rogério Duprat. Foi ele que me deu a primeira oportunidade de gravar. Ele tinha um estúdio na Alves Guimarães ${ }^{106}$, que era um dos melhores da América Latina. E foi Duprat que me colocou na música. (ASSUMPÇÃO apud PALUMBO: 2002, p.39).

Júlio Medaglia fez arranjos para o programa Vertigem gravado no teatro da TV Bandeirantes, em São Paulo, quando se apresentaram grupos da Vanguarda Paulista, entre eles Itamar. Ao que consta Medaglia não teve nenhuma relação ou interferência direta nas composições de Itamar (conforme se comprova no vídeo desse show $^{107}$ ). Destacamos esse fato apenas para lembrar de que se tratava de um evento em que, supostamente, se apresentava a vanguarda musical. A presença de Medaglia (que fez o arranjo de Tropicália, canção de Caetano Veloso, e chegou a participar de gravações de programas de TV regendo-a) parece reforçar o fato de que se tratava de um evento em que se apresentavam artistas diferenciados no cenário da música popular brasileira naquele momento.

\section{O uso da máscara}

Por fim, retomamos Zumthor para abordar um último aspecto: o significado do uso de máscara na performance. A imagem mais presente da figura de Itamar é seu rosto portando óculos escuros. Não foi possível precisar o momento exato onde ele os adotou como adereço para os shows (embora fosse míope e necessitasse das lentes para enxergar). Eram óculos de todos os tipos, coloridos, grandes e com formatos inusitados, escondendo (intencionalmente ou não) certa "fragilidade" do olhar. Em relação às roupas também, a mesma variedade e excentricidade, nos sapatos, macacões, mantos, túnicas e anéis. "No dia em que eu entrar no palco com a mesma roupa que vim da rua pode me internar!", costumava dizer. Isso demonstra sua necessidade de construir com critério a figura que estaria no palco.

\footnotetext{
${ }^{106}$ Rua do bairro de Pinheiros em São Paulo.

107 Imagens que fazem parte do documentário Daquele Instante em Diante, 2011.
} 


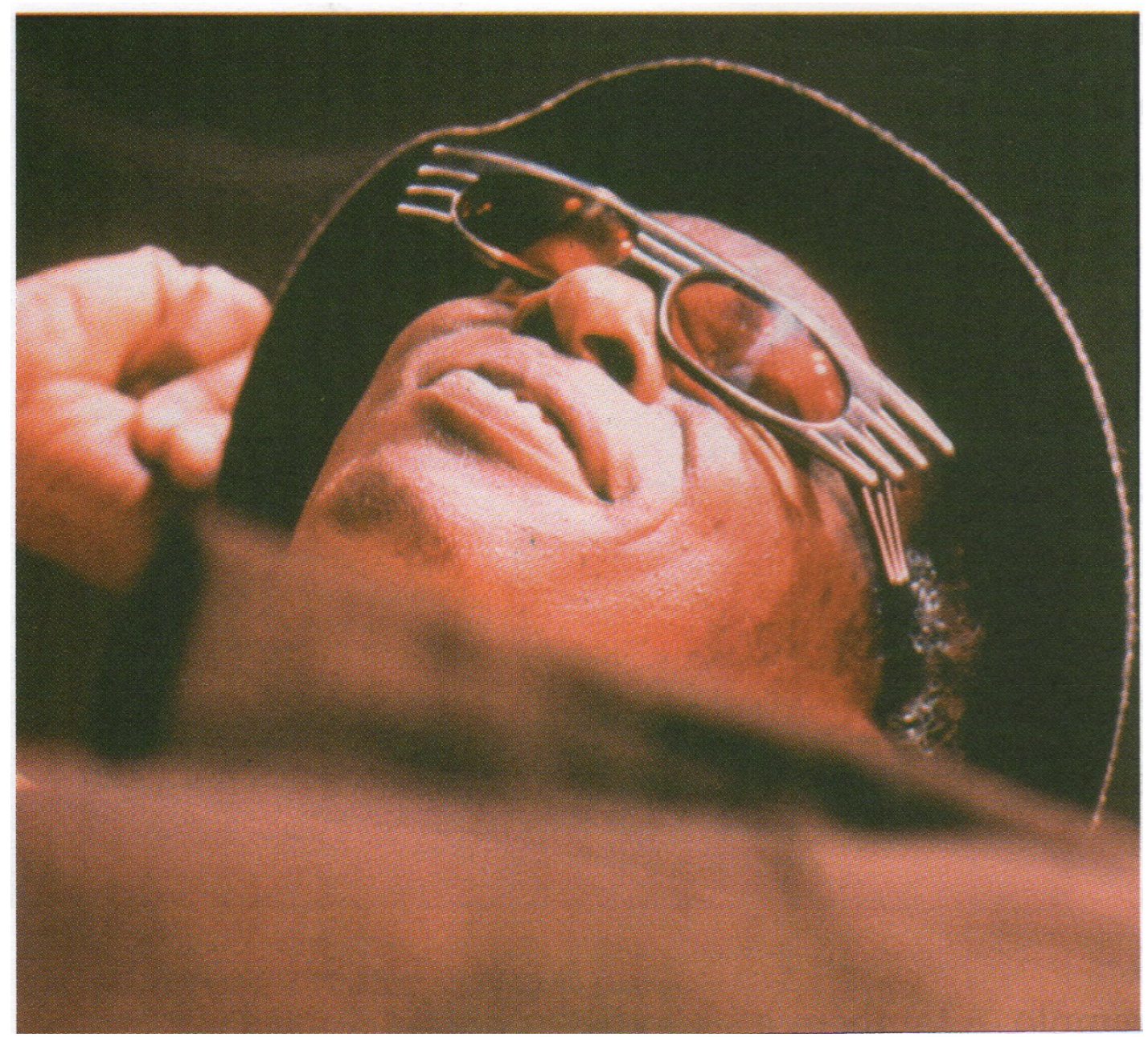

Fig. 12: Itamar Assumpção. Foto de Jorge Rosenberg

Essa figura não era necessariamente o Benedito João dos Santos Silva Beleléu, pois foi ampliada e trabalhada no decorrer dos anos. Em relação à "máscara", pois assim podemos considerar a adoção desses adereços por parte de Itamar, Zumthor nos diz:

A máscara altera quase sempre a voz [...] aquele que fala dissimula alguma coisa de sua personalidade, de sua presença, portanto. Subsiste aí uma outra presença, alusivamente significada pela máscara ou pelo traje. (ZUMTHOR: 2005 p.97)

Zumthor ainda afirma que em todas as culturas podem ser encontradas situações de performance onde o gesto se amplifica com o rosto maquiado ou o corpo disfarçado. "A caracterização pode adotar a forma estática da máscara, 
geralmente associa-se ao disfarce, traje desviante e altamente significativo." (op.cit: 2005, p.97). Assim podemos nos perguntar ao que se remete a adoção dessas vestes por parte de Itamar. À parte a atenção que tinha com o espetáculo, conforme já citamos, como se devesse ser encarado como um ritual $^{108}$ (e por isso com todos os cuidados que ele implica) a figura que constrói parece fazer parte do mundo "pop" (óculos escuros - sem finalidade de proteção de luz solar, roupas feitas de tecidos brilhantes, e sapatos ou sapatilhas coloridos). Como se fora uma "celebridade", mas com o discurso musical e poético às avessas.

\subsection{DESDOBRAMENTOS DA OBRA DE ITAMAR ASSUMPÇÃO}

A obra de Itamar não é direcional e por isso difícil de ser abordada. O personagem que construiu para ser porta voz de suas canções tem características dúbias (não sabemos se ele é doce ou ríspido) ora aparta e ameniza, ora instiga e agride. Parece refletir as constantes inquietações que teve como pessoa. Essas características estiveram presentes desde o início, sendo apenas graduadas para se desenvolverem durante os anos. As diversas matrizes que caracterizaram seu estilo de composição já aparecem no primeiro disco. Com a banda Isca de Polícia, era extremamente urbano, encontrou seu jeito de enfrentar a cidade, como interiorano que era, e de se firmar artisticamente. Os arranjos eram mais incisivos, pois apesar de inusitados mantinham uma sonoridade enxuta, bastante centrada no contrabaixo, na guitarra e na bateria e ainda remetendo-se às sonoridades de Jimi Hendrix e Bob Marley, mas reelaboradas à sua maneira. Os vocais das cantoras, que vieram a se tornar grandes intérpretes em suas carreiras solo, eram imprescindíveis, geradores de dialética. A presença do trombonista Bocato, em algumas das gravações, shows e arranjos, gerava uma terceira voz, quase invisível, mas contribuinte para a sonoridade que se alcançou. Talvez esse seja o momento mais lembrado por quem admirava sua obra, porque de fato a

\footnotetext{
${ }^{108}$ Ainda sobre o ritual (ELIADE, M. 1986, p.152) lembremos da fala de Mircea Eliade sobre o fato de que alguns aspectos e funções do pensamento mítico são constitutivos do ser humano e que perduram no mundo moderno tal como o "regresso às origens". Os ritos encenam os mitos.
} 
conjunção de circunstâncias tornou sua aparição impactante e capaz de marcar uma ruptura de linguagem.

Com as Orquídeas do Brasil deu ainda mais espaço à poesia e ao lirismo, e completou seu ciclo, abrandando um pouco as inquietações. Inspirado pelo contato com os grandes poetas Alice Ruiz e Paulo Leminski assumiu a própria poesia e tirou da composição o peso da própria figura, tornou-se mais universal. Trabalhou com a Banda Isca de Polícia por mais de dez anos (de 1980 à 1992) e com as Orquídeas do Brasil por cerca de quatro anos (de 1992 à 1995). Prosseguiu até $2003^{109}$, misturando os integrantes de uma e de outra banda, mas neste momento sem se preocupar com o arranjo, apostando na possibilidade do acaso, do improviso, e naturalmente confiando que a linguagem construída durante tanto tempo já estava devidamente introjetada pelos músicos (amigos) que o acompanhariam.

Outro desdobramento que pode ser observado é o número de parcerias que passou a constituir nos últimos anos. Parcerias tanto de letra como de música. Em sua maioria foram letras, enviadas ou ditadas pelo telefone. Com Dante Ozzeti, Ná Ozzeti, Luiz Tatit, Alzira Espíndola, Alice Ruiz, Sergio Molina, Glauco Mattoso,Tata Fernandes, Vange Milliet, Zélia Duncan propôs letras ou musicou poemas. Isso demonstra a vontade que tinha de ver seu trabalho se multiplicar, frutificar sem que fosse necessariamente sob sua tutela. Os últimos trabalhos onde podemos perceber sua presença concentrada são os dois últimos volumes da trilogia Pretobrás // e III, realizados sobre gravações de voz e violão das canções, em sua maioria inéditas, feitas nos estúdios dos amigos ${ }^{110}$ durante os anos.

Foram acrescidos à discografia quando do lançamento da Caixa Preta, com todos os CDs foram remasterizados e relançados. A Caixa Preta, tanto o nome quanto o projeto foram sua ideia. Uma prova póstuma para quem desejasse saber sobre os percalços de seu voo, e um registro para a posteridade. Segundo o que imaginava, ela e o Song Book seriam um produto

\footnotetext{
${ }^{109}$ O último show aconteceu em 25 de fevereiro de 2003, no Centro Cultural do Banco do Brasil em São Paulo.

${ }^{110}$ A era digital facilitou incrivelmente os processos de gravação, tirando grande parte do ônus e das dificuldades que havia na época dos primeiros discos.
} 
só. No entanto ambos projetos demandaram muito tempo para serem concluídos, por serem trabalhosos, e por terem sido realizados com critérios cuidadosos. O Song Book foi concluído em 2006 e a Caixa Preta em 2010. Há ainda um último projeto que Itamar pediu que fosse concluído, como se fosse seu. Entregou ao compositor Sergio Molina onze letras para que ele as musicasse. Pediu que fosse gravado um disco onde a intérprete seria a cantora Miriam Maria, integrante das Orquídeas. Esse trabalho foi concluído em 2009, e falaremos sobre ele adiante. Sigamos com o estudo sobre as composições. 


\section{CAPÍTULO 2 - ANÁLISE DAS COMPOSIÇÕES: OITO MATRIZES}

De alguma maneira, já no primeiro disco Beleléu, leléu, eu (1980), podese dizer que estão presentes as principais matrizes que caracterizam a obra de Itamar. Elas são desenvolvidas e exploradas no decorrer das fases que se sucedem. A utilização do termo matriz significa não somente verificar os elementos básicos intencionalmente explorados para gerar a composição como também as tipologias definidas a partir dos processos que as completam (tal como os arranjos, as gravações e as execuções ao vivo).

Nota-se, nesse início, o atrelamento das composições à figura de Itamar (quer seja sob o personagem Beleléu, ou a ele mesmo) e a tendência, no decorrer do tempo, de distensão dessa relação, aparentando libertar a canção para ser autônoma e poder ser apropriada por vozes de outros cantores e por outros arranjos. Por fim, num último momento, a dedicação de Itamar à escrita de letras, buscando parceiro (as) ${ }^{111}$ para que compusessem músicas sobre as palavras (e curiosamente, muitas vezes, se recusando a ouvir o resultado final da combinação). Ou seja, sem a necessidade de continuar pensando em melodias, linhas de baixo ou arranjo, simplesmente escrevendo poesia.

Algumas das matrizes que sugerimos a seguir são advindas, como já foi dito, do processo de transcrição do song book ${ }^{112}$. Esse processo tornou visível a suposição de determinadas características. Ao realizar a notação foram identificadas algumas recorrências de procedimentos composicionais que requereram layouts específicos para atendê-las nas partitura, tal como a presença de uma grade onde permanentemente estão presentes a linha de baixo e a melodia, ou a inclusão de falas ritmadas (sem entoação de alturas). Outras matrizes sugeridas advêm da escuta e da percepção de relações internas estruturais da composição, que nada têm a ver com a evidenciação trazida pelo aspecto estético da grafia da partitura. E ainda a percepção da relação que há entre a composição e a intenção de interpretação e de

${ }^{111}$ Ná Ozzetti, Alzira Espíndola, Luiz Tatit, Dante Ozzetti, Sergio Molina, Tata Fernandes, entre outros.

112 ASSUMPÇÃO: 2006, vol I, p.79- 85, onde descrevo os critérios adotados para as transcrições. 
performance. E por fim a valorização da poesia e as diversas possibilidades de proferi-la e de cantá-la através da voz.

Evidentemente essas matrizes não são puras, estão impregnadas mutuamente. Bem como não parecem apresentar relação de "linha evolutiva". São aqui separadas apenas para que sejam identificados os traços mais fortes, aqueles cujos indícios haviam sido citados no capítulo anterior (sobre a formação musical de Itamar); aqueles que parecem ter sido reelaborados de maneira pessoal por ele e que intencionalmente destaca. Foram escolhidas uma ou mais canções para representarem cada uma das matrizes (e para serem analisadas sob os aspectos que elas levantam) sendo que os exemplos de outras composições são também citados para reforçar a argumentação apresentada. Conforme já foi mencionado, não existe a intenção de que com a definição dessas matrizes se pretenda torná-las definitivas. Sua adoção deveuse a uma estratégia de aproximação à obra.

\subsection{Do contrabaixo}

Dentre as diversas características presentes nas composições de Itamar, a valorização e a presença do instrumento contrabaixo elétrico é a mais óbvia. É uma das primeiras informações notadas, mesmo para uma escuta não especializada. No entanto essa valorização não é literal, no sentido de querer dar destaque à especificidade de um timbre simplesmente por uma questão de gosto. Podemos resgatar a ideia explicitada pela própria fala de Itamar, já citada anteriormente, de quanto, em sua visão, o instrumento the permitia congregar a liberdade de utilizar frases rítmicas com alturas, trazendo o caráter da horizontalidade, do contraponto, ao invés de ter que se ater à harmonia e à melodia acompanhada. Interessava-Ihe a "conversa", a presença de um interlocutor que possuísse uma voz particular, que estaria presente tecendo seus comentários musicais enquanto uma fala principal fosse articulada com palavras. Vale lembrar que as vozes femininas presentes nos vocais também desempenham o papel de diálogo, no entanto o interlocutor "contrabaixo" se diz sem palavras, e permanece mimetizado, para esta função, na paisagem da 
seção rítmica, uma vez que a voz tem a prioridade de trazer a atenção principal para si.

O contrabaixo nos remete aos tambores africanos (quer seja dos batuques de umbigada ou da umbanda) e à questão aditividade das células rítmicas presente na musica africana (questão também já apresentada) que interfere na percepção da métrica da canção, expandindo ou comprimindo a sensação de duração dos compassos, e na percepção do pulso básico.

Temos ainda mais um aspecto que é o de entender o contrabaixo como um elemento constituinte de composição. Algumas composições foram criadas a partir de uma linha de baixo, ou concomitantes a ela. $E$ isso quer dizer que essa melodia secundária também pode se manter fixa (mesmo possuindo características de assimetria), e funcionar como balizadora para melodia principal, como um território rítmico-melódico por onde ela pode circular. Não é possível dizer com certeza quais são as composições onde a linha de baixo foi força geradora, pois embora essa afirmação tenha sido feita pelo próprio Itamar, ele não as exemplificou. Mas é possível identificar músicas onde ocorre uma nítida autonomia da canção quando a melodia é acompanhada somente pela linha de baixo, permanecendo plena com a presença desses poucos elementos ${ }^{113}$. Além disso, é importante relembrar a questão de que algumas das linhas de baixo que serão exemplificadas aqui podem eventualmente não ter sido compostas por Itamar, ou somente por ele. Já frisamos essa característica presente na música popular urbana e rural, de que a consumação de uma canção muitas vezes se dá coletivamente, incluindo a etapa de arranjo ${ }^{114}$. Tratamos aqui de identificar os traços estilísticos que

\footnotetext{
${ }^{113}$ Quando o compositor e pesquisador Luiz Tatit propõe uma abordagem (visando a análise musical) que leva em conta prioritariamente o perfil melódico e afirma que há uma aproximação entre o canto e a fala (Tatit: 2007, p.160) acaba considerando indiretamente que a síntese da canção seria a própria melodia, desprovida de harmonia, de arranjo ou instrumentação, interessando principalmente a voz que entoa. Notamos muitas vezes que na música de Itamar, a presença dessa outra "voz", que é o contrabaixo, altera o sentido musical da melodia e da poesia, remetendo-nos àquela voz que é anterior à linguagem, da qual fala Paul Zumthor. A resultante musical do jogo que ocorre entre as duas vozes, a que carrega as palavras e a voz grave do contrabaixo, é quem define a paisagem e as fronteiras do território onde se vai circular.

${ }_{114}$ Há vários músicos participantes no trabalho de ltamar Assumpção, às vezes elencados nas fichas técnicas dos CDs, e às vezes não (por não ser possível denominar com clareza o papel desempenhado) envolvidos nas tarefas de arranjo e produção tais como o trombonista Bocato,
} 
foram sendo gerados pelo compositor ou agregados sob sua aquiescência, por compatibilidade com o estilo.

\section{Navalha na liga}

A canção Navalha na Liga, do disco Sampa Midnight, é um bom exemplo da presença do contrabaixo no papel de elemento de apoio e contraponto à melodia. Embora a frase tocada por ele possa ser vista como um riff, na medida em que estabelece um ciclo que é repetido por toda a extensão da músicas, parece ter parentesco com as características iniciais da melodia. Ajuda a propulsiona-la no início, já que parte da mesma divisão rítmica (fig.13).
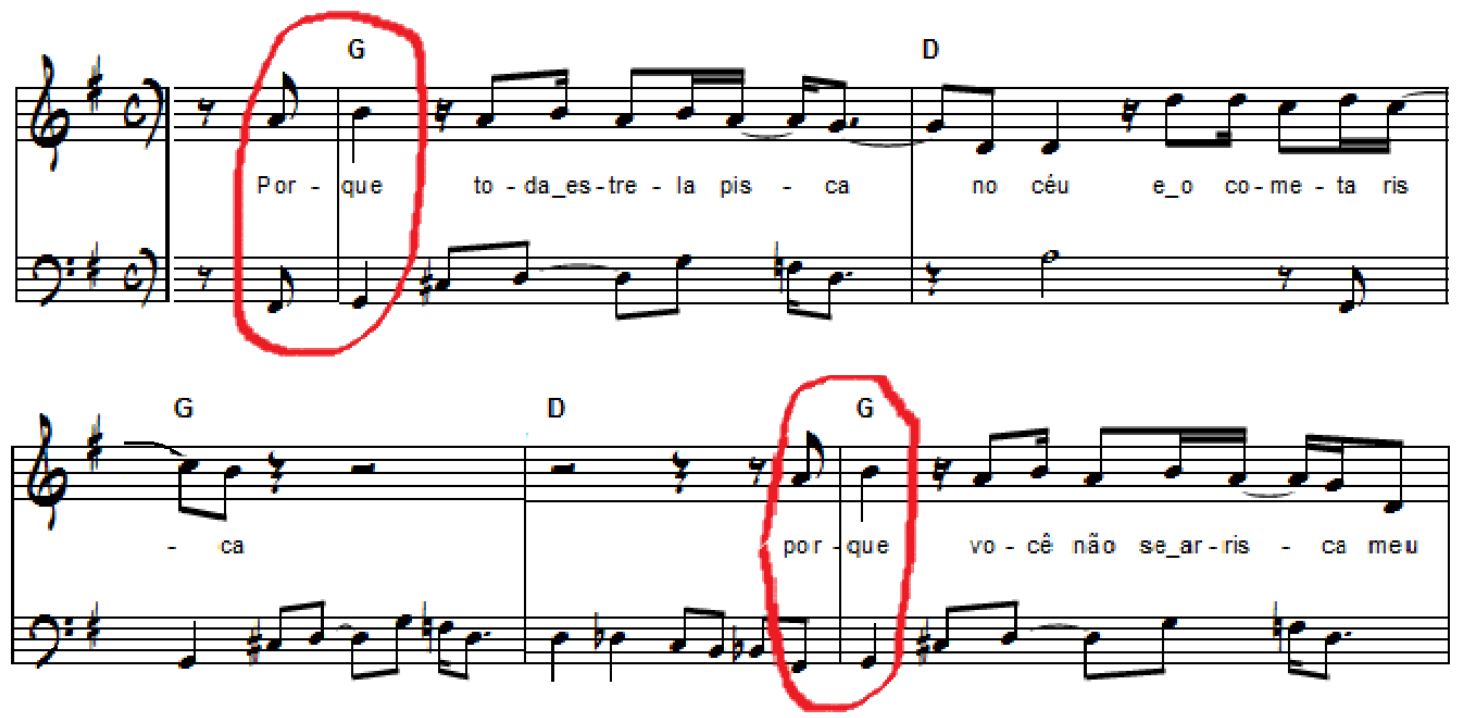

Fig. 13 Navalha na Liga, melodia e linha de baixo. (CD anexo faixa 1)

Mais à frente quando a melodia assume outras características rítmicas e melódicas, a linha de baixo, que já havia se tornado familiar ao ouvinte adquire novo frescor por ter sido justaposta a uma ideia diferente. Passa a chamar atenção para si novamente (ao invés de alavancar a melodia que porta o poema), e a gerar outro contexto. Segundo Alice Ruiz (RUIZ apud Assumpção: 2006, vol.I. P.67, e na entrevista em anexo), parceira de letra dessa canção, Itamar recolheu alguns trechos de poemas e poemas curtos publicados em

o contrabaixista Paulinho Lepetit, o baterista Gigante Brazyl, o guitarrista Luiz Chagas, da Banda Isca de Polícia. 
seus livros e os compilou para a canção. Este fato a surpreendeu na medida em que não imaginava haver o tipo de unidade de conteúdo alinhavado por Itamar. A característica cíclica da linha de baixo parece então favorecer a "costura", auxiliando a junção dos pequenos textos. A presença do vocal masculino dobrando a linha de baixo corrobora com a ideia, defendida até então, de considera-la também uma voz que se expressa sem utilizar palavras.

A linha de baixo de Navalha na liga (fig.14) possui ainda a característica de levar-nos, mesmo que sutilmente, à questão das defasagens métricas. A pausa de semínima, que ocorre no primeiro tempo do segundo compasso, seguida de uma mínima (num intervalo de quinta - nota lá - do acorde dominante, D7), articulada com acentuação, pode dar a entender que a melodia do contrabaixo ocorre em um compasso de 5 tempos somado a um de 3 tempos (além dos dois a mais de 4 tempos seguintes), ao invés de quatro compasso comuns de 4 tempos. Na música de Itamar é através da disposição de pequenos detalhes como este que os elementos musicais, apesar de simples, vão sendo articulados pouco a pouco e tornam o resultado final complexo.

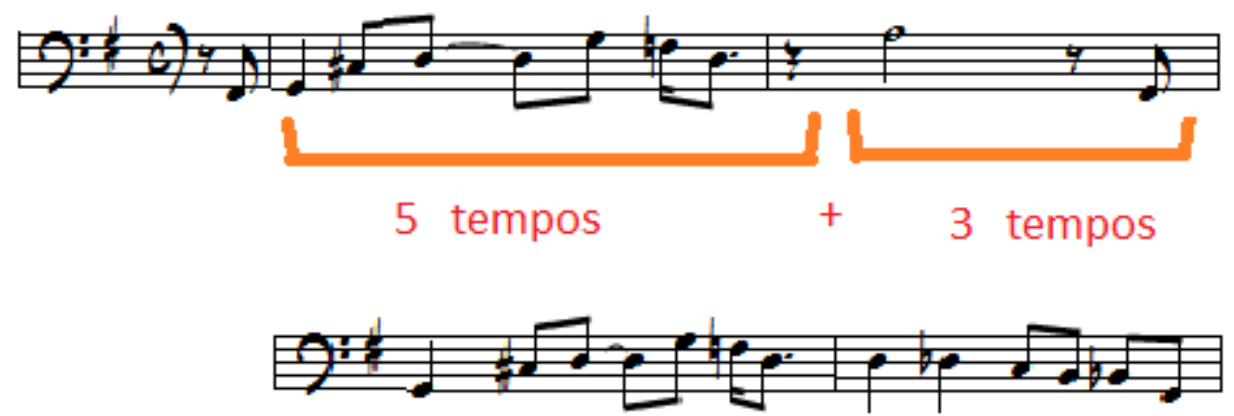

Fig. 14 Navalha na Liga: linha de baixo sugerindo métrica assimétrica

\section{Luzia}

É importante ressaltar que no disco Beleléu, leléu, eu, de onde provém essa gravação, Itamar tem uma participação grande como instrumentista, tocando na maioria das faixas (inclusive nesta) baixo, guitarra, percussão e piano, além de cantar. Nos discos seguintes Itamar também grava instrumentos, mas aos poucos é uma tendência que diminui (acaba gravando 
quase sempre violão). Este é seu primeiro disco, lançado pelo selo Lira Paulistana em 1981. É possível observar o resultado (e talvez a influência) do período de pesquisa e estudo, ao qual nos referimos anteriormente através do depoimento de Paulo Barnabé - os anos nos quais participou da criação dos arranjos de base de Arrigo Barnabé e de suas próprias composições, e nos quais realizava sessões de escuta com 0 intuito de aprender e identificar procedimentos e processos musicais.

Nesta gravação torna-se transparente o cuidado com o arranjo e a necessidade de se evidenciar uma sonoridade específica, decorrente da utilização dos instrumentos de banda (da formação que acabou sendo consagrada pela música pop mundial, que tem como alicerce baixo elétrico, bateria e guitarra) ajustados para serem sincrônicos na execução das distintas ideias rítmicas. Transparece por isso também, o trabalho dispendido com ensaios.

A linha de baixo desta música apresenta comportamentos distintos. Aqui não ocorre somente um ciclo, uma melodia de apoio. Esse procedimento não seria possível já que são cinco seções que se sucedem, alterando o centro tonal inclusive. Durante a música Luzia o fraseado alia-se ao discurso do personagem Beleléu, toma rumo próprio e no final soma-se ao da própria Luzia.

É notável, com já foi dito, que Itamar buscou a concisão de linguagem no decorrer dos anos. Desta forma, a partir da trilogia Bicho de sete cabeças não se encontram mais canções formadas por diferentes seções. Assim com ele passou a admirar haicais (influenciando a construção de seus textos) trouxe também a concisão para a forma musical, às vezes composta por uma só seção. Por isso essa canção é quase uma exceção. No entanto a interpretação de Itamar, como contrabaixista, é bastante esclarecedora a respeito das questões que temos colocado sobre o papel do instrumento no resultado das composições.

Parece evidente que a linha de baixo foi composta por ele (pelo fato de ter sido a pessoa que a gravou e por participar do processo geral de 
arranjo). A maneira como o tempo das notas é distendido no ataque (através de nuances de dinâmica e de tipos distintos de toques na corda), parecem flexibilizá-lo sem a perda da precisão. Esses procedimentos, além da ideia musical à qual servem, ajudam a destacar a linha de baixo ${ }^{115}$ para a audição, tornando-a um personagem presente, que respira.

No trecho assinalado (fig. 15), percebe-se que a rítmica de melodia e da linha de baixo não deixam que os respectivos ataques de notas coincidam. Essa defasagem parece preparar a reincidência da palavra "deixa" (do texto que profere a reclamação do personagem Beleléu, que vem logo em seguida), onde a abertura dos vocais enfim sincronizam o tempo reforçando a queixa. $O$ baixo, que havia ficado em pausa, volta para alinhar-se ao que diz a voz: "bláblá-blá".

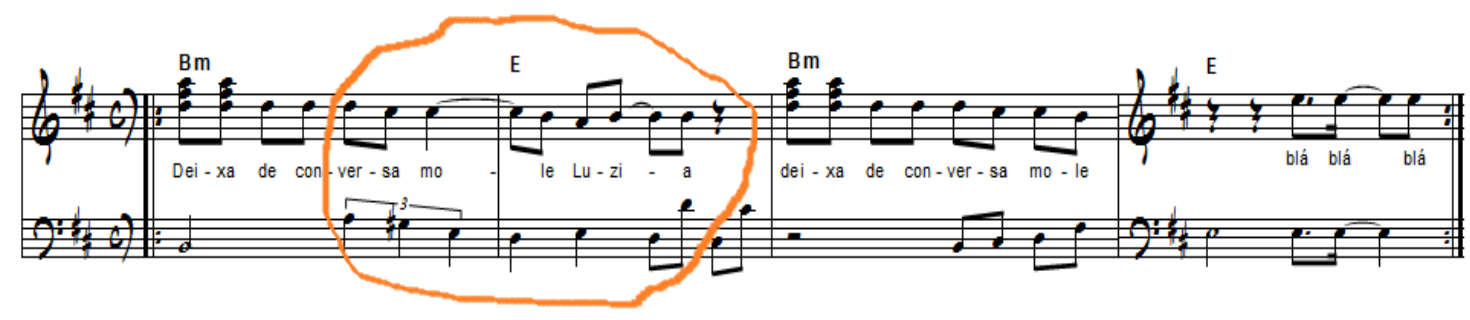

Fig. 15: Luzia, polirritmia entre a linha de baixo e a voz. (CD anexo faixa 13)

É interessante resgatarmos uma característica das frases rítmicas que provavelmente provém dos batuques de umbigada, descritos no primeiro capítulo: a presença de tercinas. Naquela situação essas células rítmicas são utilizadas como estruturais. Nota-se que Itamar muitas vezes as insere também, tanto nas linhas de baixo como nas melodias, em momentos específicos quando quer marca-los. Isso faz com que notemos que, tanto na música de Itamar como nos batuques de umbigada, a característica "dançante", normalmente percebida e assim chamada pelo ouvinte comum não está

\footnotetext{
115 Itamar toca contrabaixo em quase todas as músicas do álbum, com exceção de Baby (executada pelo músico Pamps) e Nego Dito (executada por Kiko, a quem também é atribuído, na ficha técnica, o "fraseado de baixo" - isso comprova que as linhas de baixo foram de fato compostas por Itamar). A escuta dessas gravações exemplifica e esclarece a questão interpretativa a qual me referi, como sendo bastante sofisticada, e que está acoplada à ideia musical que quer transmitir. Ou seja, mais uma vez aqui a questão da performance. Itamar busca expressão ao tocar as frases de contrabaixo por que são nelas que vislumbra a função de equilíbrio, onde os outros acontecimentos musicais podem se apoiar.
} 
associada necessariamente à percepção da presença da sincopa, tão ocorrente nos diversos gêneros brasileiros e suas dança, tais como o samba. As tercinas, neste contexto, têm a função de criar polirritmias. Na música de Itamar praticamente não há sincopas.

As notas escolhidas para a linha de baixo (ainda no mesmo trecho assinalado) permitem um amálgama não usual entre os acordes, comparandose a alguns dos procedimentos que são comuns (do ponto de vista melódico) na composição de linhas nos diferentes estilos, dentre eles o walking bass. Apesar de a linha traçar uma melodia, ela não quer reforçar as tríades dos acordes, pois sequer passa pelas terças. No caso do acorde de Mi maior (IV grau), inicia-se com a sétima menor, alternando com a fundamental do acorde e depois passa pela sexta maior (do sustenido ${ }^{116}$ ). Essa sexta, como é seguida de uma pausa, deixa-se soar como passagem indicando que chegará a algum lugar, que se confirma a seguir, no arpejo de Si menor que caminha (aí sim como walking bass) para chegar novamente ao acorde do quarto grau.

O que ocorre nessa situação confirma a ideia de que o enfoque não é vertical e sim predominantemente horizontal. Ou seja, neste caso, não há a preocupação em atrelar a composição da linha de baixo à função de caracterizar a harmonia, ou de afirmar os momentos de mudança de acordes, procedimentos extremamente comuns na música popular. Isso não quer dizer que esse procedimento mais corriqueiro não ocorra em outras canções de Itamar. Ainda assim, quando o há, verifica-se a utilização de artefatos rítmicos para tentar produzir o efeito de horizontalizar.

É possível ainda observar mais uma característica presente: a linha de contrabaixo sendo oitavada pela a guitarra. Nesta gravação de Luzia, essas dobras ocorrem em momentos específicos sendo que a guitarra retoma diferentes fraseados e conduções rítmicas logo em seguida, alternando os dois procedimentos.

\footnotetext{
${ }^{116}$ A nota dó sustenido que aparece na linha de baixo está também na melodia. Na melodia é uma nota forte, pois aparece como nona (se considerarmos o primeiro acorde de si menor), embora o acorde seja triádico. E segue como antecipação melódica para a entrada de mi maior (sendo neste caso a sexta maior), também triádico. Portanto a presença de dó sustenido também na linha de baixo reforça a ideia de construção melódica contrapontística, imitando a melodia da voz.
} 
Outro exemplo está na música Peço perdão (fig.16), do disco As próprias custas S.A. O fraseado de baixo é dobrado por uma das guitarras durante todo o tempo:
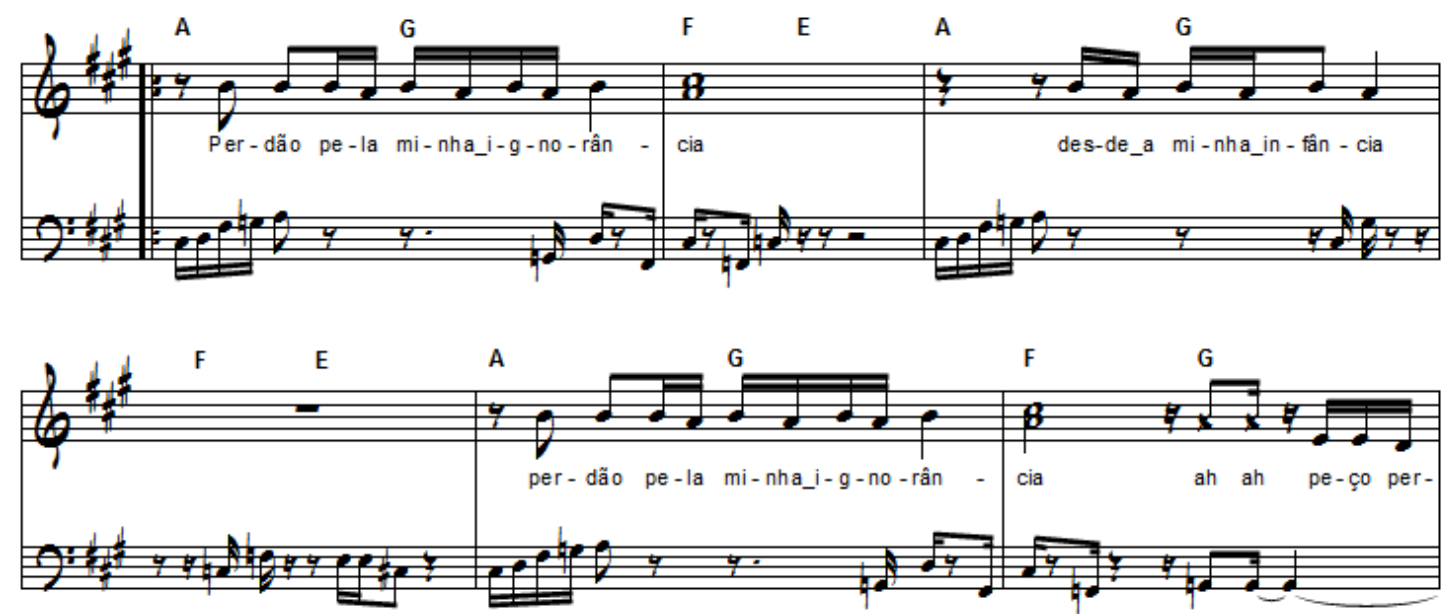

Fig. 16: Peço perdão - baixo dobrado com guitarra. (CD anexo faixa 14)

Esse tipo de arranjo pode ser encontrado nas canções de Jimi Hendrix $^{117}$, que também adotava como banda base a mesma instrumentação, 0 trio formado por sua própria guitarra, baixo e bateria, além da voz. Um exemplo bem claro sobre isso está na canção Fico Louco (fig.17), do mesmo disco Beleléu, a partir do trecho abaixo. Fica claro que a linha de baixo assume a frente, não só por manter uma melodia, enquanto a voz diz o texto como fala, sem alturas, como por ter a guitarra tocando a mesma frase (uma oitava acima). Esse trecho também apresenta semelhança com linhas de baixo de reggae, tal como o estilo criado por Bob Marley ${ }^{118}$ (a quem Paulo Barnabé se

\footnotetext{
117 Itamar escutou os discos de Jimi Hendrix. Nas gravações de músicas como Hey Joe, Foxy Lady, Jam back at the house, e Voodo child há vários momentos de dobras de melodia da guitarra com o contrabaixo elétrico, que lembram os procedimentos que ocorrem em alguns trechos da composições de Itamar. E não somente as dobras (que também ocorrem no rock ou em outros estilos), mas a construção de frases que funcionam como ponte (convenção), ou como condução horizontal, sem o pré-requisito de ter que definir a harmonia. Há também a utilização do efeito wah-wah, um equipamento (pedal) associado ao uso da guitarra que altera a equalização do instrumento permitindo que o músico acrescente a frequência média e a retire rapidamente gerando alteração do timbre numa mesma nota ou acorde. Há até hoje uma marca desse equipamento (chamado de cry baby) que leva o nome de Jimi Hendrix, já que ele foi um dos pioneiros em sua utilização. Todos os guitarristas que tocaram com Itamar utilizaram esse pedal, pois era um dos elementos timbrísticos importantes para a manutenção da sonoridade que imaginava.

${ }_{118}$ Por exemplo, em canções consagradas de Marley como Is this love, Could you be loved, e Exodus, as linhas de baixo também possuem de alguma maneira o caráter de apoiar a melodia com frases que são contrapontísticas. Na música de Bob Marley também nota-se os
} 
referiu, em entrevista anexa, como tendo sido uma forte referência para ambos, ele e Itamar). A impressão de que o compositor se utilizaria diversos gêneros musicais em sua composição, dando ênfase ao reggae é feita informalmente em conversas entre músicos próximos ao compositor (como já pude presenciar), e até em estudo acadêmico ${ }^{119}$. No entanto essa percepção não leva em conta as diversas raízes fincadas por Itamar para estabelecer seu próprio estilo, tanto se utilizarmos essa analogia para refletir sobre variedade de informações com as quais trabalha, como para investigar a profundidade alcançada pelo compositor com o processo de elaboração dos materiais musicais. Afirmar que ele adota este ou outro gênero (é possível sim identificar a presença implícita do samba ${ }^{120}$ por exemplo), significaria dizer que o mesmo predomina, e que no processo está apenas sendo reproduzido, e não reelaborado conforme estamos tentando demonstrar. O reggae apareceria como uma referência sim, visível em alguns traços (como a adoção rítmica da guitarra, tocando nos contratempos, e também com o efeito wah-wah), mas tanto quanto outras encontradas neste estudo. Um exemplo desta menção ao reggae está na canção Fico louco (fig.17), onde a frase autônoma do contrabaixo (também dobrada pela guitarra) lembra muito o estilo.

\footnotetext{
instrumentos sendo utilizados de maneira rítmica, combinados para criar células que se completam. Há ainda a presença forte dos vocais femininos, embora com um uso mais convencional do que aquele pensado por Itamar.

${ }_{119}$ (Falbo: 2009, Recife p.46)

120 Não seria necessário comprovar o fato de que Itamar escutou a profusão de sambas presentes na música popular brasileira, já que o estilo sempre foi tocado nas rádios. A escolha em realizar um CD (em 1995) sobre o compositor Ataúlfo Alves, que era um sambista, demonstra seu conhecimento a respeito da tradição. Os arranjos desse trabalho poderiam fornecer indícios, se aprofundados em outro estudo, a respeito de como um estilo pode ser reelaborado, já que pela abordagem de Itamar não há literalidade. Em todas faixas ele faz questão de nos fazer esquecer o fato de que as canções de Ataúlfo se tratavam de sambas, e nos lembra que são canções, antes de tudo. Podemos identificar contudo, referências de samba em canções como Leonor, Estrupício ou mesmo Nego Dito. Nessas composições observa-se a presença de sincopas nas melodias, embora os arranjos e o tipo de acompanhamento não sejam típicos do estilo.
} 


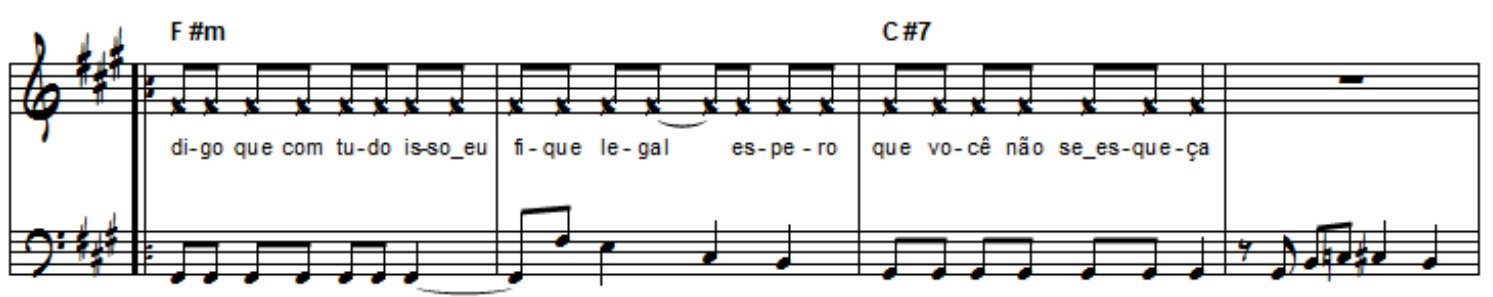

Fig. 17: Fico louco, linha de baixo com características de reggae e oitavada com a guitarra.

(CD anexo faixa 15)

\section{Outros exemplos da matriz contrabaixo}

Destaquemos ainda mais dois aspectos da questão para completar os exemplos, e para que possamos seguir com a definição das outras matrizes sugeridas.

Primeiro a frase de contrabaixo como propulsora da ideia da composição. No exemplo a seguir, a canção Dor Elegante ${ }^{121}$ (fig.18), temos a manutenção de uma linha de baixo, que permanece constante, mesmo com a modificação da melodia que serve às diferentes estrofes e ao refrão. Trata-se de uma poesia de Paulo Leminski musicada por Itamar. Essa canção foi tocada por muitos anos sempre com a mesma linha de baixo ${ }^{122}$. Isso nos faz entender que, neste caso, ambos os elementos (voz e contrabaixo) eram abordados como uma coisa só, integrada. Quando Itamar apresentou essa canção às Orquídeas do Brasil, conforme pude testemunhar, já a tocou desta maneira. A linha de baixo pode ser entendida também como um resumo do movimento rápido dos acordes. Ela é construída somente com as fundamentais desses acordes $^{123}$. E também é possível que os acordes tenham sido inseridos depois, baseados na linha de baixo.

${ }^{121}$ Canção que já foi citada no primeiro capítulo, quando fizemos considerações sobre a performance ao vivo, no show realizado em 2002, no teatro Itaú Cultural em São Paulo. Lá Itamar canta à capela.

${ }^{122} \mathrm{Na}$ gravação do disco Pretobrás I, o contrabaixista Paulinho Le Petit acrescenta outras notas no momento do refrão para gerar variação. No entanto, a manutenção de mesma linha inicial poder ser mantida, assim como fazia Itamar ao tocá-la.

${ }_{123}$ Nota-se que Itamar tinha uma maneira muito peculiar de tocar violão. Muitas vezes seu toque de mão direita era percussivo, abafando as cordas e não deixando que os acordes soassem integralmente. 
Em outras canções Itamar chegava a modificar os arranjos e as linhas de baixo para os shows, sem se ater à referência das gravações e sem se apegar aos arranjos originais. Mas nesta canção não. Conforme já havíamos dito não é possível garantir com certeza em quais músicas esse procedimento ocorreu, temos apenas a referência dada pelo depoimento de Itamar e a dedução através de evidências como essas citadas acima, aliadas à escuta. Mais uma vez verifica-se a autonomia da canção apenas com a presença de dois elementos básicos, a voz (que canta o poema) e a linha de baixo.
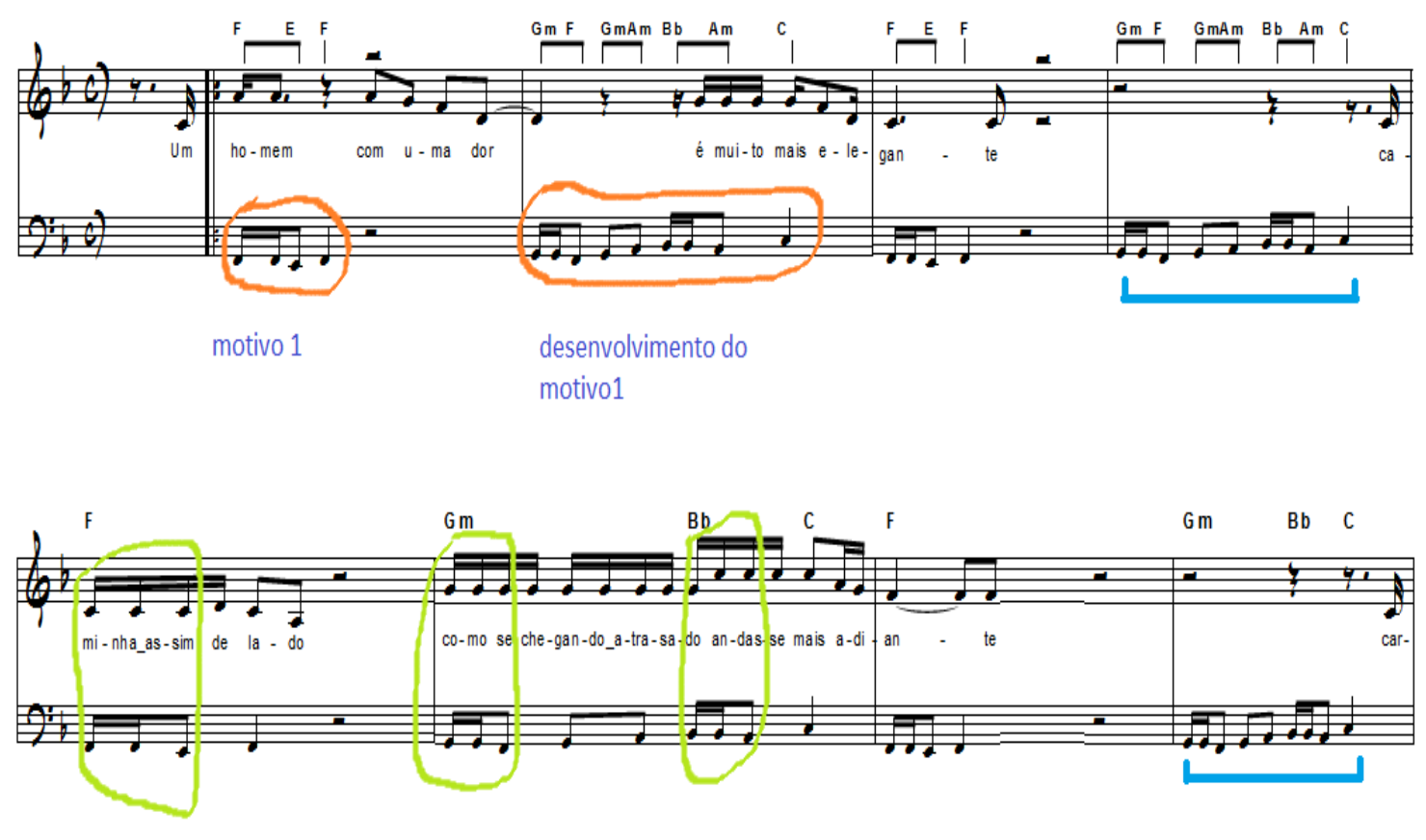

Fig. 18: Dor elegante, linha de baixo como elemento gerador da composição. (CD anexo faixa 11)

A linha de baixo é construída com um motivo rítmico que se desenvolve. Ela é cíclica e curta, como se pode notar, e apoia as pausas da voz mantendo o entendimento do pulso e mantendo o fluxo. Quando Itamar a canta à capela (no exemplo sobre performance, do primeiro capítulo) a ausência da linha de baixo traz a sensação de que essa pausa é bastante extensa. No entanto a presença da linha de baixo não anula o efeito de expectativa criado pela pausa da voz. Completa sim à canção o caráter irônico da letra, na medida em que o motivo rítmico sobre o qual é construída pode ser associado ao andar do homem elegante que sente dor, e que "caminha de lado". A linha de baixo 
ascendente parece exprimir triunfo, enquanto na melodia descendente da voz, o texto afirma que o homem que sente dor é muito mais elegante que os outros, e por terminar numa nota grave, vindo desse movimento de descida da melodia, coloca em dúvida a veracidade da afirmação que está sendo feita.

Há ainda o efeito, gerado pela linha de baixo, de propulsionar a melodia (observado também na canção Navalha na Liga) quando parte da divisão rítmica da melodia coincide com a divisão rítmica do motivo da linha do baixo. Assim, nesta canção, o contrabaixo se coloca de uma maneira simples (pois não contem complexidade na construção melódica ou rítmica), mas presente no papel de respaldar a melodia, "contracenando" com ela, tornando-se quase que indissociáveis. A canção Sujeito à chuvas e trovoadas ${ }^{124}$ é outro exemplo de linha de baixo construída somente a partir do movimento das tônicas dos acordes e que serve ao mesmo tempo como respaldo para a melodia e como contraponto, sendo possível supor que foram compostas simultaneamente, ou de maneira concatenada.

\section{Dois contrabaixos}

O último aspecto a ser referido, para tratar da importância das linhas de baixo na música de Itamar Assumpção, tenta contemplar a questão da utilização de dois contrabaixos. A peculiaridade neste procedimento está no fato de que ambos os instrumentos tocavam linhas distintas, sem formarem um naipe, tal como ocorre nas orquestras sinfônicas a partir do romantismo, onde há até oito contrabaixos tocando praticamente o tempo todo em uníssono (e eventualmente efetuando divises, ou destacando um solista).

A ideia de Itamar era antiga, mas só pôde exercitá-la e colocá-la em prática no trabalho com as Orquídeas do Brasil, na trilogia Bicho de sete cabeças. Como a experiência era nova para o compositor, desenvolveu uma maneira própria de relacionar os dois instrumentos. E o fez na prática, durante as gravações e os ensaios, sem que houvesse preparação previa sobre o que cada instrumento tocaria.

\footnotetext{
${ }^{124} \mathrm{O}$ anexo 7 é uma lista em ordem alfabética de todas as canções indicando a qual disco pertencem.
} 
Na trilogia há duas canções (Lambuzada de dendê e In the morning) cujo arranjo para dois contrabaixos foi encomendado ao contrabaixista Mario Campos. É possível observar como as soluções de arranjo, de Itamar e de Campos, diferem entre si. Campos sugere um arranjo claro, com as tessituras e as funções dos dois instrumentos bem definidas. Há sempre um contrabaixo que assume a função que normalmente assumiria o instrumento (se estivesse sozinho, no contexto da canção popular urbana) situando-se no grave e realizando a condução usual (utilizando-se de elementos rítmicos e descrevendo a harmonia nota por nota). O outro, por oposição coloca-se na região aguda do instrumento, funcionando como uma guitarra, imprimindo características harmônicas (tocando mais de uma nota ao mesmo tempo) e tecendo comentários. Observemos aqui a canção In the morning (fig.19):

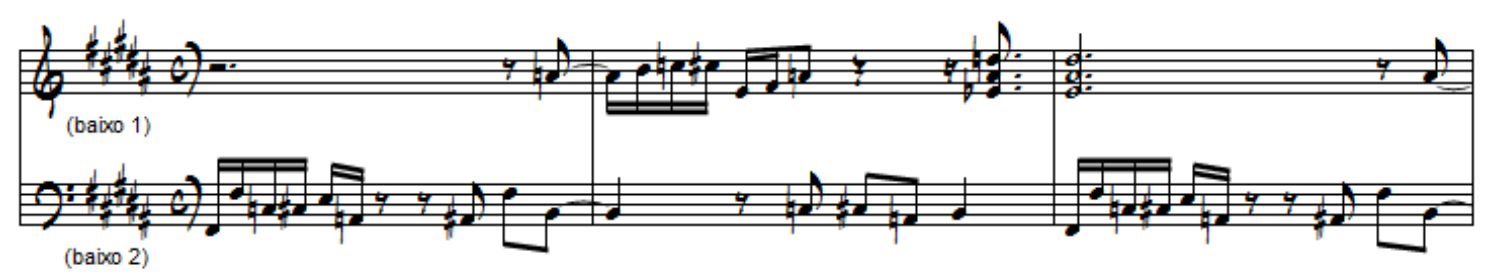

Fig. 19: In the morning, arranjo de Mario Campos para dois contrabaixos. (CD anexo faixa 16)

Por sua vez, as soluções de arranjo encontradas por Itamar para permitir a convivência de dois contrabaixos são diversificadas. Para cada música desenvolve um tipo de procedimento, sem padronizá-lo a fim. Verificaremos mais adiante como, em muitos casos, os instrumentos, em geral, são tratados como se fossem "contrabaixos", já que as melodias adotadas assemelham-se à tipologia das frases desses. Um exemplo específico de arranjo, que exige audição acurada, está na canção Venha até São Paulo (fig.20). Essa música é um rap, pois trata-se de um texto sendo falado de maneira ritmada, sobre uma base. Haveria, em princípio, uma dificuldade de discernimento das frequências graves presentes através da escuta. As duas melodias criadas são executadas em regiões muito próximas na tessitura (mais ou menos na faixa de frequência entre 40 e 120hz), sendo que o baixo 2 mantem sua nota mais grave soando enquanto o baixo 1 se movimenta. Um dado que "clareia" a escuta está no fato 
de que a frase do baixo 2 é dobrada pelo piano. A soma dos instrumentos gera um terceiro timbre. Assim essa "massa" sonora poderia ser análoga ao que se vivencia na cidade de São Paulo, da qual fala a letra: "venha até São Paulo ver o que é bom pra tosse". Ao mesmo tempo, é nessa cidade onde há "socorro", "liberdade", "bom retiro", "saúde", "luz" (que são naturalmente os nomes de alguns dos bairros, mas que ditos por Itamar assumem status de substantivo) e onde todos cabem, conforme diz a letra.

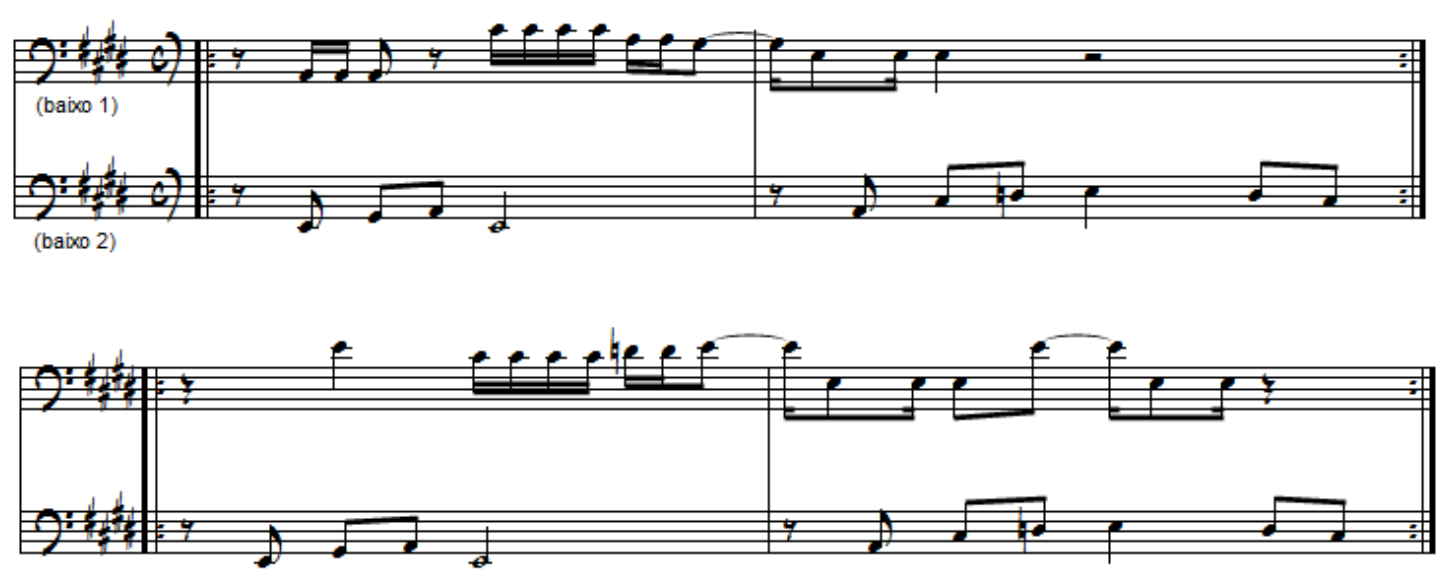

Fig. 20: Venha até São Paulo, arranjo de Itamar Assumpção para dois contrabaixos. (CD anexo faixa 17)

$\mathrm{Na}$ canção Sonhei que viajava como você ( $\mathrm{CD}$ anexo faixa 2), citada no primeiro capítulo, para exemplificar a questão da métrica assimétrica, os dois contrabaixos estão situados em regiões bem distantes na tessitura, e o baixo 2 , que efetua a condução tem a dobra do sax alto. Enquanto isso o baixo 1 executa uma frase melódica, sem afirmar a condução. Portanto uma abordagem de arranjo diferente, talvez com alguma semelhança ao que ocorre no arranjo de Campos, se entendermos que a diferença de região e de tessitura entre os dois instrumentos é uma maneira de facilitar seu discernimento. No entanto reforçamos novamente a questão da horizontalidade das frases. Não há um pensamento harmônico e sim contrapontístico. É assim também na música Penso logo sinto, só que neste caso o baixo que está no agudo é que é dobrado pela flauta, enquanto o que está no grave atua sozinho. Já na canção Ai que vontade, há o predomínio de um contrabaixo na função de 
condução, enquanto o outro responde, executando a mesma frase oitava acima a cada pausa desse primeiro. No final, o contrabaixo mais agudo soma-se à flauta para enfatizar o refrão.

Observamos então que as direções de função estabelecidas para os dois instrumentos vão sendo ajustadas a cada música. A presença de dois contrabaixos indica também o surgimento de outra matriz de composição, que utiliza frases modulares.

\subsection{Das frases modulares.}

Podemos notar que a exploração de frases musicais modulares ocorreu principalmente no trabalho com as Orquídeas do Brasil. Algumas circunstâncias ocorridas já vinham interferindo gradualmente nas características das composições e se acirraram a partir do momento em que dois contrabaixos passaram a trabalhar juntos (na metade de 1991, quando foram realizados os primeiros ensaios e uma pequena temporada na Sala Guiomar Novais, em São Paulo), provavelmente contribuindo para que esses traços se firmassem. Primeiro o fato de que a nova banda foi formada em decorrência da ruptura com os músicos que acompanhavam Itamar anteriormente. A banda Isca de Polícia, que havia estado com ele por pouco mais de dez anos, foi dissolvida. Itamar dispensou músicos com larga experiência (em seu estilo, inclusive) para iniciar um novo trabalho, com musicistas iniciantes. Quando perguntou a uma de suas vocalistas na época Tata Fernandes ${ }^{125}$ se conhecia instrumentistas mulheres, para que pudessem formar uma nova banda, Itamar expressava a necessidade de modificar a maneira de trabalhar, de modo a oxigenar aquilo que parecia estar se esgotando. Em entrevista à revista Qualis, em novembro de 1994, Itamar diz:

As Orquídeas representam uma outra linguagem, uma coisa nova dentro dessa complexidade que se chama MPB. A partir do muro de mulheres dessa primeira reunião eu parti para os arranjos. Foi a partir do que elas tocavam que eu preparei os arranjos. ( Revista Qualis:1994, p52)

\footnotetext{
${ }^{125}$ Segundo depoimento de Tata Fernandes no documentário Daquele Instante em Diante (2011). Tata foi também vocalista da Banda Isca de Polícia.
} 
Apesar de os instrumentistas da Banda Isca haverem introjetado a música de Itamar, atingindo extrema proficiência em seu estilo, com as Orquídeas do Brasil havia a possibilidade de recomeçar, partindo de pressupostos diferentes, mesmo que causando uma ruptura.

Nesse momento também se consolidaram as parcerias com Alice Ruiz $^{126}$. Além disso, a nova formação incluía mais instrumentos, bateria, percussão, saxofones e flauta, guitarra, vocais e dois contrabaixos (segundo Paulinho Le Petit esta era uma ideia antiga, que não havia sido colocada em prática até então). O trabalho se iniciou já com a gravação em estúdio da trilogia Bicho de Sete cabeças. Além de as instrumentistas não estarem familiarizadas com o estilo, a nova formação e a presença de dois contrabaixos (o que não é usual em música popular, já que cada um dos instrumentos tocava uma linha própria, sem formar um naipe) exigiam outras soluções para os arranjos. Naquele momento, de início de trabalho, Itamar cantava a melodia que pensava para cada instrumento, inclusive o ritmo que seria executado pela bateria e pela percussão. Esse procedimento acabou contribuindo para imprimir essa característica que chamamos de "modular", de peças que se encaixam e que podem ser reconfiguradas e recombinadas. Essa solução se tornou eficaz principalmente para o tipo de composição, mais sintética em termos da parte musical. As composições continham uma, ou no máximo duas sessões, suprindo assim a necessidade de variação através da combinação desses módulos, da sobreposição, do sequenciamento ou da omissão dessas frases modulares. As gravações acabaram consolidando algumas dessas combinações, sendo confirmadas também nos shows subsequentes, onde as músicas foram tocadas ao vivo. No entanto percebe-se que seria possível altera-las sem modificar drasticamente as características da composição.

No caso dessa leva de composições sabe-se que o arranjo foi pensado posteriormente, e que, portanto, nenhum desses elementos que acabamos de descrever foi propulsor da ideia básica da composição. Porém elas se

\footnotetext{
${ }^{126}$ Alice Ruiz afirma que fizeram mais de vinte músicas juntos. Um último projeto de CD, só com as parcerias, não pôde ser finalizado, pois se extraviaram as gravações em fita cassete das músicas feitas por Itamar sobre os poemas.
} 
completaram através do arranjo, que passou a integrá-las como se sempre houvessem estado presente.

A questão dos dois contrabaixos, já citada na matriz anterior, gera o predomínio de uma faixa grave de frequência sobre a qual se constituem os outros timbres e as outras tessituras. Esse fato cria naturalmente uma dificuldade na inteligibilidade dos sons. Ou seja, quando da prevalência de frequências graves, mesmo que cada contrabaixo executasse alturas distintas (melodia diferentes) os outros instrumentos eram locados em outras regiões como uma das maneiras de torna-los presentes e destaca-los, atribuindo-Ihes frases marcadas. Mesmo assim, para a escuta das gravações desse período, é necessária uma atenção especial para perceber os detalhes e conseguir adentrar pelas camadas densas de som e de informação, além da utilização de efeitos tais como reverb, vencendo a etapa de não encontrar de imediato as brechas para isso.

\section{Milágrimas}

Essa parceria com Alice Ruiz é um exemplo rico do casamento entre letra e música. Merece um pequeno parêntese antes de identificarmos as frases modulares que contém, motivo pelo qual a selecionamos aqui. Segundo Alice ambos trabalharam juntos na canção, mas apesar de cada um ter cuidado prioritariamente mais de uma coisa do que de outra (ela da poesia e ele da música), Itamar sugeriu acrescentar um detalhe que considerou significativo à letra: "Em caso de tristeza vire a mesa, coma só a sobremesa, coma somente a cereja". A "cereja" incrementou a síntese e a imagem ao representar os conselhos dados à mulher para ajudá-la a sair do estado de tristeza. Com essa frase (sublinhada) ele amplia a expressão já desgastada "comer a cereja do bolo" no sentido de ser metáfora para ação de quem só vai aproveitar o que for melhor. Nesse contexto, a frase sugere que a mulher busque a objetividade e a simplicidade (que já estão contidas em seus desejos) como meio de ação para ganhar autoconfiança para sair do estado de tristeza, mais do que querer usufruir de algo só porque aparentemente é o que de melhor há. 
Prossigamos com as diversas melodias dos instrumentos, que se encaixam e se sobrepõe (fig.21):

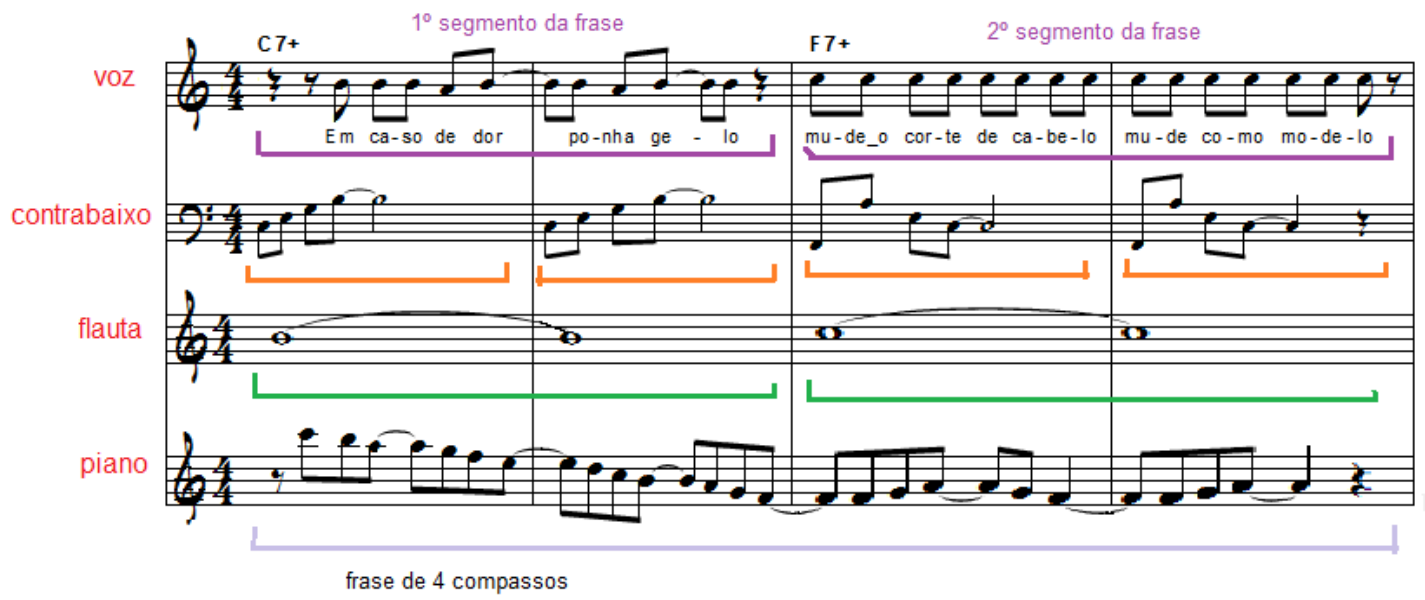

Fig. 21: Milágrimas, melodia da primeira parte da canção. (CD anexo faixa 18)

A inteligibilidade da transcrição para a partitura ficaria garantida, no caso desta canção, somente com a notação da melodia e das cifras (dos acordes), fato que em outras composições de Itamar é insuficiente, conforme já verificamos. Portanto, as informações acrescidas pelo arranjo não interferem estruturalmente. Funcionam como uma espécie de ambiência, onde sua entrada ou saída apenas gera uma modificação na paisagem. Tampouco aqui o contrabaixo tem papel que seja fundamental. Os segmentos em cores (fig.21) mostram como as quadraturas das frases possuem diferentes extensões, sugerindo possibilidades de atrelamento e de encaixe de uma em relação à outra $^{127}$. A melodia mais extensa é a que o piano toca, e que ocupa toda a amplitude do verso. Mais uma vez chamamos a atenção para o papel exercido pelos instrumentos nas composições e nos arranjos de Itamar. Em muitas situações o piano não exerce a função harmônica como é o procedimento comum na música popular urbana. $\mathrm{E}$ isso se confirma também nesta canção.

Nessa primeira seção, a estrutura se mantém semelhante também na segunda estrofe do texto. Já na segunda seção (fig.22) temos a entrada de mais instrumentos e frases:

\footnotetext{
${ }^{127}$ A música pop sempre se utilizou desse expediente, da utilização de segmentos melódicos, executados por instrumentos diferentes e que se combinam.
} 


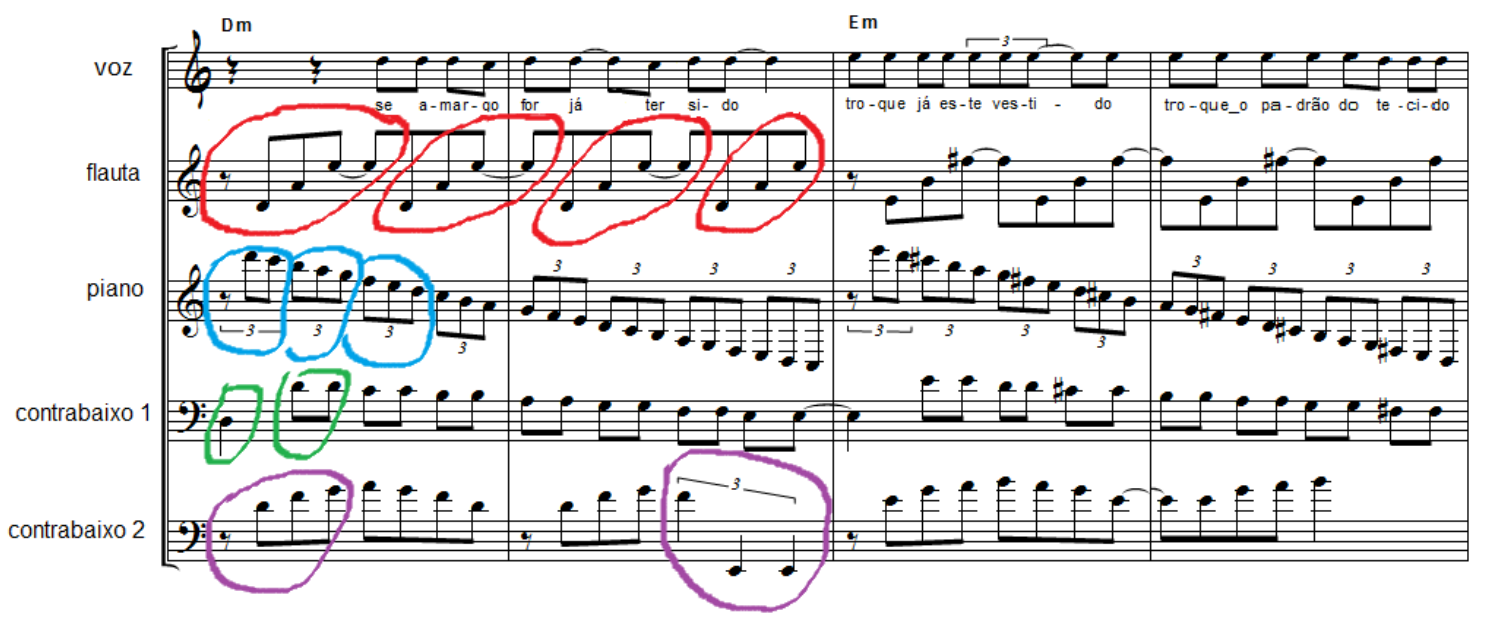

Fig. 22: Milágrimas, segunda seção da canção - motivos rítmicos e presença de frases modulares.

Aqui o encaixe das diversas melodias não se dá através de diferença de proporção entre as quadraturas, conforme verificamos na primeira parte da canção. Todas as frases duram dois compassos. Essa modularidade ocorreria no aspecto interno que as compõe, através dos pequenos motivos rítmicomelódicos e através das direções de altura que assumem. Pelo meio da escuta percebemos muito mais uma ideia de colagem e de sobreposição do que de contiguidade e complementariedade, embora haja pontos de contato entre os acontecimentos musicais. Por exemplo, observando o que ocorre com a melodia do piano, que é descendente e se utiliza de uma escala, o modo dórico. Como se empregam tercinas de colcheias esta frase transpassa três oitavas, já que as emissões de notas são rápidas. Enquanto isso o contrabaixo 1 executa a mesma escala, também descendente em colcheias ${ }^{128}$ e por isso com uma rítmica aumentada, alcançando somente uma oitava. O efeito, então, seria o de profundidade mais do que simetria ${ }^{129}$. Outro exemplo que pode justificar a designação de modular para esse tipo de construção estaria na segunda parte do verso quando essas duas frases são transpostas para um tom acima, logo na sequência. São dois acordes, ré menor na primeira frase e mi menor na segunda frase. Se levarmos em conta o campo harmônico, a escala esperada para o terceiro grau (o mi menor) seria o modo frígio. Mas o

\footnotetext{
${ }^{128}$ Todas as colcheias são tocadas em jazz feeling, ou seja, tercinadas conforme se diz no jargão da música popular.

${ }_{129} \mathrm{O}$ fato de utilizarmos o termo modular não quer dizer que estejamos pensando em equilíbrio simétrico ou numa estética de equivalência.
} 
compositor utiliza o mesmo modo dórico também sobre terceiro grau o que causa uma pequena estranheza já que trabalha dentro do universo tonal. Mais uma vez a ideia da colagem. A flauta e o contrabaixo 2, por sua vez utilizam-se de arpejos. A construção de frases com arpejo sobre tríades é bastante comum nos arranjos de Itamar $^{130}$, tanto para os instrumentos como para os vocais. A flauta e o contrabaixo 2 compartilham um motivo rítmico melódico semelhante sendo que, enquanto a flauta anuncia a antecipação da entrada do acorde seguinte o contrabaixo afirma $o$ acorde onde se encontram. Enquanto isso a melodia da voz se mantem utilizando poucas notas (com pouca variação de altura).

\section{Custa nada sonhar}

Nesta canção (fig.23) ocorrem procedimentos semelhantes: o "jogo" de profundidade entre os instrumentos que tocam notas mais longas e os que tocam notas mais curtas e rápidas; o uso de escalas simultâneo ao uso de arpejos, como materiais contrastantes; além das diferenças métricas entre as frases, que defasam entre si (a polimetria, conforme KOSTKA: 2006 e TUREK: 1996). O contrabaixo (o primeiro) respalda a melodia da voz, pois sua quadratura corresponde a todo o primeiro verso, apresentando uma linha que se assemelha, desta vez sim, a um walking bass. Nesta canção surge também uma mescla de poesia cantada com poesia falada, pois na primeira parte 0 texto é cantada e na segunda falada, mas dentro do andamento. Falaremos sobre isso mais detalhadamente na matriz 5 , que é sobre a fala ritmada e os aspectos rítmicos que influenciam as construções melódicas.

\footnotetext{
${ }^{130}$ Vide canções como Batuque (onde até os vocais se utilizam de arpejos), Que barato (linha de baixo arpejada), ou o arranjo de Meus tempos de criança (canção de Ataúlfo Alves).
} 


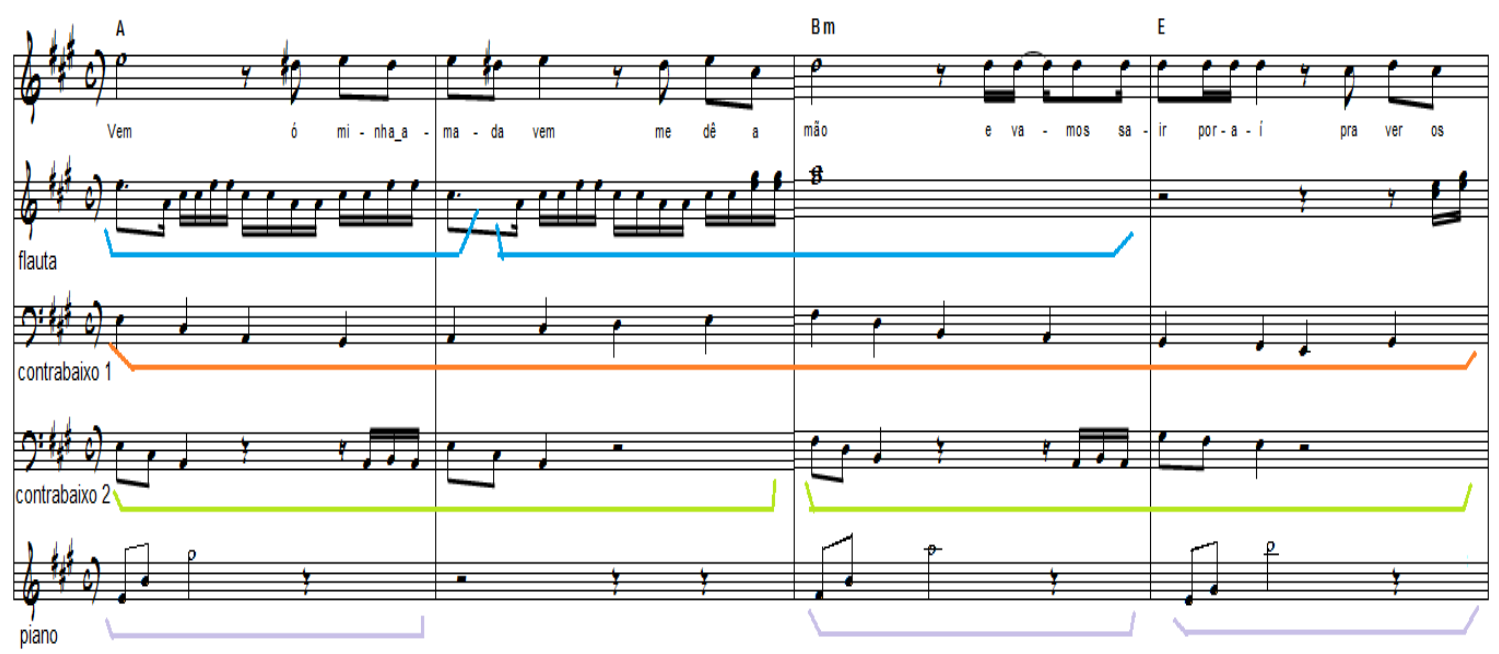

Fig. 23: Custa nada sonhar, canção com frases modulares. (CD anexo faixa 19)

\subsection{Da música do século $X X$.}

O período em que o primeiro disco de Itamar, Beleléu, foi gravado é muito próximo da época em que trabalhou com Arrigo Barnabé, sendo momentos quase simultâneos. É através desse veio, explorado por Arrigo, que Itamar tomou contato com o tipo de música erudita realizada pelos compositores do século XX que quebraram alguns dos paradigmas do romantismo e da música tonal. Principalmente com o dodecafonismo e o atonalismo livre. $O$ contato com esse universo se deu através da reelaboração que a música de Arrigo propunha. Arrigo trouxe essas informações para a canção popular, e esse fato era novidade até então. Portanto, Itamar não escutou as composições Stravinsky e Schoenberg. Ele já se relacionou com as informações via a criação de Arrigo, fazendo arranjo. $O$ interessante é observar que mais uma vez trata-se de um fazer vinculado à intuição, pois as escolhas não estão baseadas numa técnica específica. Sobre as canções que estão relacionadas aqui, como tendo sido "influenciadas" pela música do século $\mathrm{XX}$, observamos que se trata muito mais da busca de Itamar em se aproximar de uma sonoridade através da memória que possuía dela, do que de tentar reproduzi-la estruturalmente. De alguma maneira, quando Itamar queria que prevalecesse um elemento mais acentuado de estranheza, buscava essa sonoridade. É interessante notar que a menção a Arrigo, equivalendo também à sonoridade a qual Itamar o via como sendo portador, está no primeiro disco 
(Beleléu) e também no último (Pretobrás 1). Fecha o ciclo desta forma, e demonstra que essa ambiência sonora de fato participava dos elementos constituintes de sua concepção musical.

No primeiro disco, Beleléu, Itamar grava a canção Aranha (fig.24) uma parceria de Arrigo Barnabé, Neusa Pinheiro Freitas e Rondó. Embora conste no encarte original do LP o nome de Itamar como coautor da canção, segundo Arrigo, Itamar apenas a quis gravar porque gostava da composição. Arrigo compôs a linha de baixo e Rondó a melodia sobre o poema de Neusa. Poderemos observar adiante o quanto Itamar buscava intuitivamente, em outras composições que realizou sozinho, o efeito de instabilidade na sonoridade (ou de desestruturação do centro tonal) através dos intervalos, principalmente da utilização de acordes diminutos. Quando queria obter um efeito de "estranhamento" recorria a esses recursos para atender ao teor da poesia - tal como ocorre, de alguma maneira nesta canção, que utiliza elementos musicais específicos que fazem jus à letra, ao falar da teia em que se enreda e sob a qual não se há como encontrar saída.

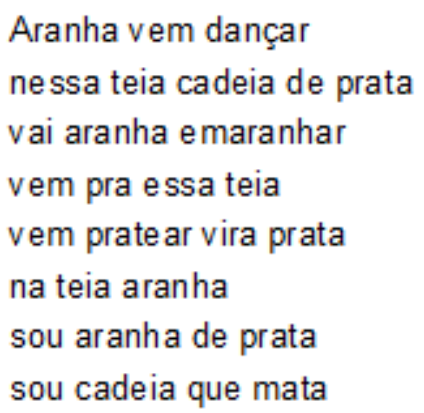

Fig. 24: Aranha, letra. (CD anexo faixa 20)

\section{Enquanto penso nela}

A canção Enquanto penso nela, é outro exemplo de aproximação à sonoridade resultante da utilização de dissonâncias. Apresenta além da utilização de acordes diminutos a oscilação entre a escala maior e a diminuta de Mi (fig.25). Sugere um pouco da sonoridade diferenciada em relação à maioria de suas canções, na medida em que a poesia é curta e os sons são descritivos, apontam mais uma atmosfera do que um sentido de direção claro: 


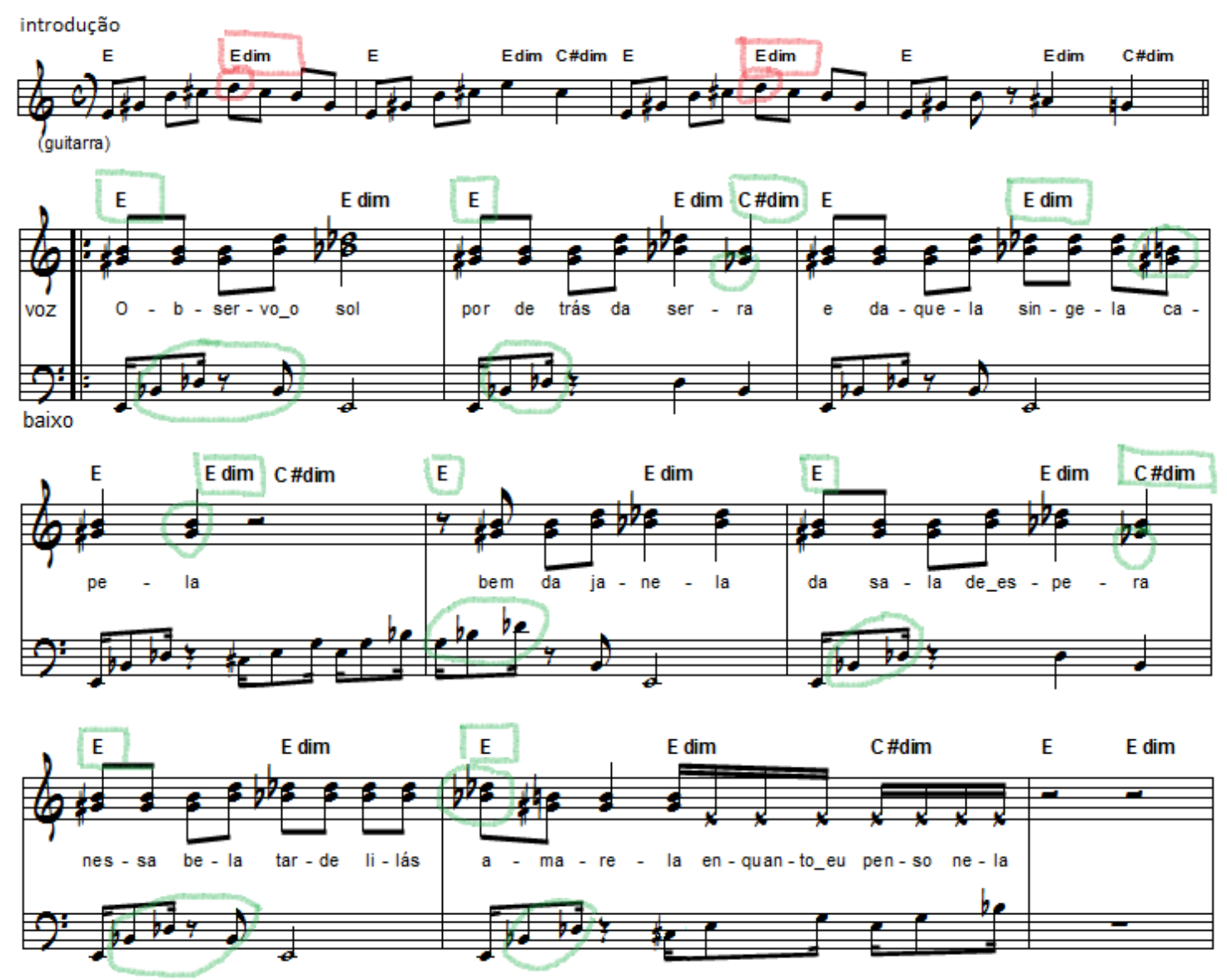

Fig. 25 Enquanto penso nela, utilização de dissonâncias. (CD anexo faixa 21)

Estão assinalados os momentos (nas cores vermelha e verde) em que as notas da melodia e das linhas dos instrumentos (guitarra e baixo) conflitam com as notas dos acordes tocados pelo violão ${ }^{131}$. A aparente "estabilidade" pode ser sentida pela abertura de vozes, em terças, que confere familiaridade à escuta, ocultando as dissonâncias melódicas entre as linhas e a base. Assim como, a linha da guitarra que reproduz uma linha de baixo de rock dos anos $60^{132}$ e que se desenrola à revelia das mudanças de acordes, e por ser um modelo conhecido também se torna um elemento de reconhecimento para o ouvinte.

\footnotetext{
${ }^{131}$ Por exemplo, na linha da guitarra, a sétima menor sendo tocada sobre um acorde diminuto (fig.26, compassos 1 e 3). Ou então na melodia, um intervalo de quarta justa sobre um acorde de Do\# diminuto (compasso 2) a voz cantando solb sobre sol natural (do acorde); o mesmo ocorre no compasso 3, quando a abertura de vozes canta as notas sol\# e si, terça maior e quinta justa respectivamente sobre um acorde de Mi diminuto (onde soam sol natural e si bemol), e etc.

${ }^{132} \mathrm{Tal}$ como Rock around the clock, de Bill Harlley.
} 


\section{Amigo Arrigo}

Observa-se procedimentos semelhantes em outra canção, Amigo Arrigo, presente no último CD:

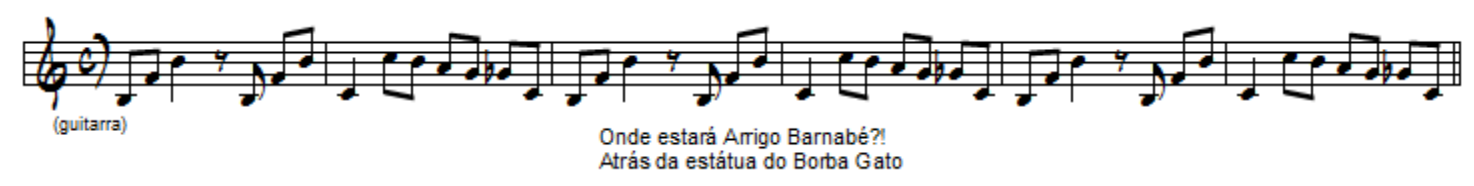

Fig. 26 Amigo Arrigo, linha da guitarra. (CD anexo faixa 3)

A guitarra é o único instrumento além da voz. A linha tocada (fig. 26) utiliza a as escalas de Si lócrio, num arpejo incompleto e Do lídio, mesclandoas. Mais uma vez a ênfase no intervalo de trítono como sendo referência para gerar estranhamento. Essa canção, que é quase uma vinheta ${ }^{133}$, apresenta outros pontos de contato com a via expressa por Arrigo Barnabé (através de sua tradução da música erudita do século XX para o universo da canção popular). Primeiro a ideia de compasso assimétrico, neste caso forjado pela acentuação da voz e da repetição do texto, que faz crer (fig. 27) que sejam dois compassos de três tempos somados a outro de dois ${ }^{134}$. Outro ponto trata-se da relação harmônica que se estabelece entre a curta melodia e a frase da guitarra $^{135}$ (ainda fig.27). A linha da guitarra sugere dois acordes, Si diminuto (assinalado em roxo) e Do maior (assinalado em laranja). Sendo assim as notas da melodia ocorreriam em graus mais altos da escala, explorando as dissonâncias possíveis em relação às tríades (nos compassos 5, 6, e 7 - la, do e sol, sobre o acorde de $\mathrm{B}$ dim; e ré e si sobre o acorde de $\mathrm{C}$ maior). Verificamos que muitas das melodias compostas por Itamar estão baseadas em intervalos triádicos sem sugerir o afastamento da tonalidade ou quebra da ideia de centro tonal, e que portanto, na situação desta música ele busca uma solução diferente.

\footnotetext{
${ }^{133}$ Por possuir um poema curto e por ser construída sobre uma linha melódica de dois compassos.

${ }^{134}$ Aspecto que também se relaciona a adição de células, característica da música africana, apresentada no primeiro capítulo.

${ }_{135}$ Essa melodia poderia ser entendida como uma linha de baixo, tal como Itamar costumava a concebê-la. Há, entretanto, com a escolha da tessitura mais aguda e do timbre com efeito, uma variação na sonoridade em relação às canções desse mesmo disco de onde provém.
} 

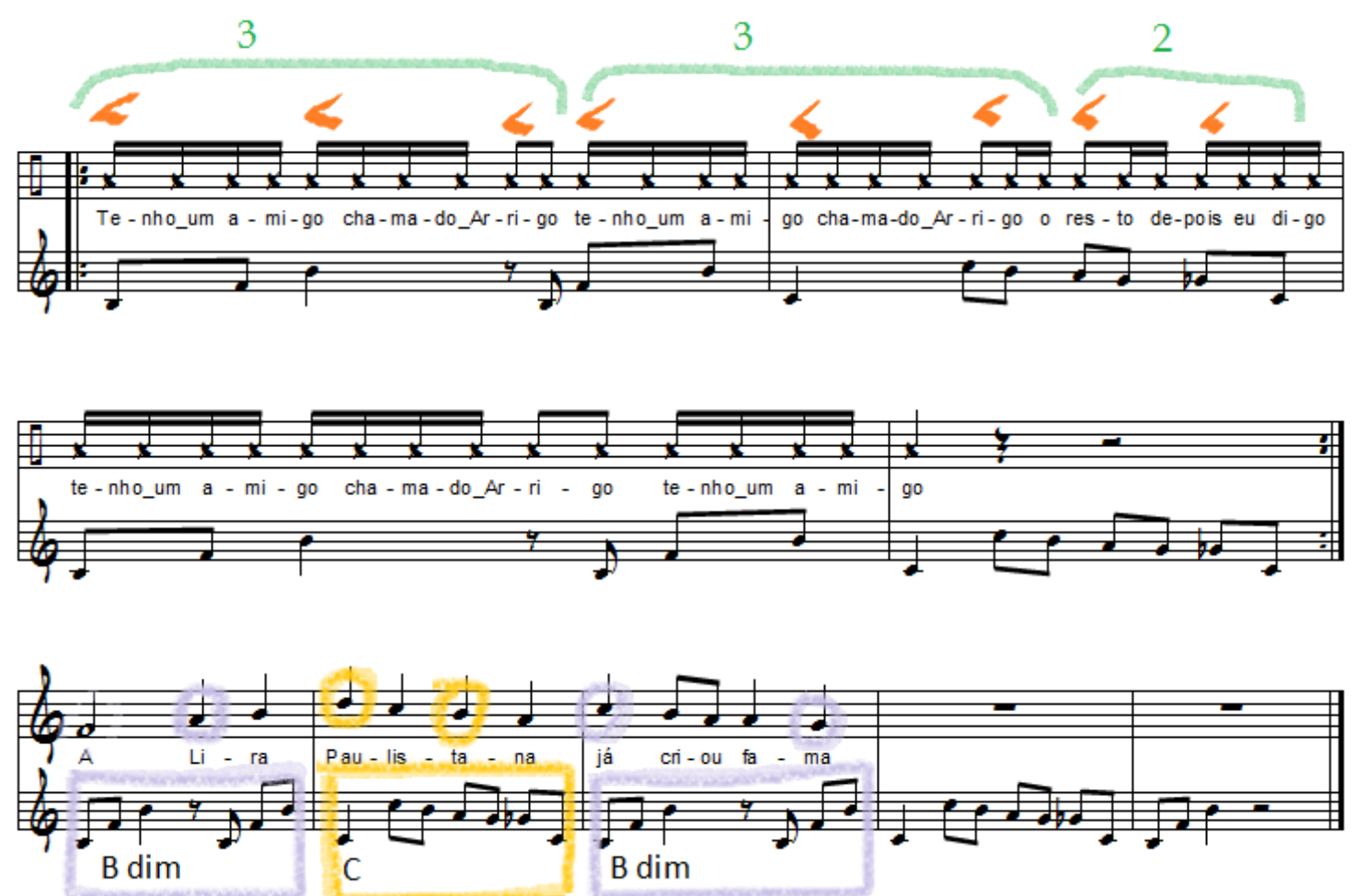

Fig. 27 Amigo Arrigo, quebra da ideia de compasso e melodia com notas dissonantes.

(CD anexo faixa 3)

\subsection{Da voz feminina, como personagem e presença.}

"A voz, em certos casos, se impõe a tal ponto que tende a dissolver a linguagem." (Zumthor, 2005, p.65)

Mais uma vez, quando destacamos a voz para ser observada, ressurgem agregadas todas as questões que já foram colocadas, a respeito da performance, do aspecto ritualístico (ligado à origem da existência) que evoca, da relação que possui com os processos de criação e etc. A voz feminina na música de Itamar não é um elemento que passa despercebido. Nas gravações ela está presente nos vocais e em interpretações solo de cantoras convidadas. Está presente também como personagem. São, por isso, vozes provocadoras pois evidenciam um pouco da contradição e do dinamismo inerentes à vida. 
Na música de Itamar a voz feminina é ao mesmo tempo, uma espécie de arauto da justiça que visa ordenar os conflitos (tal como em Denúncia dos Santos Silva Beleléu, onde é tanto uma personagem como a própria justiça de quem Beleléu é réu), e em outras situações a "causa" dos conflitos (como em Luzia, Desapareça Eunice, Justo você Berenice). Além disso, há uma profusão de visões a respeito da mulher, das situações que sua presença provoca e dos tipos de canto que expressam isso.

Portanto, a voz feminina estaria nas personagens criadas no texto de Itamar e está também na variedade de timbres expressos pelas cantoras, negando ou afirmando essas personagens. Nesse sentido não se trata de um adereço do arranjo e sim de outro pilar do fundamento da composição sabendo que essas vozes (o canto executado por cantoras mulheres) foram acrescidas depois do processo de composição, mas considerando-as, a partir da presença, como constituintes permanentes e essenciais ${ }^{136}$.

No livro A voz na Canção Popular Brasileira - um estudo sobre a vanguarda paulista, Regina Machado fala sobre o surgimento de um tipo de voz feminina que ocorreu dentro da Vanguarda Paulista, das especificidades do canto das intérpretes que trabalharam com Arrigo Barnabé e com Itamar Assumpção (Suzana Salles, Virgínia Rosa, Vânia Bastos, Tetê Espíndola, Ná Ozzetti, algumas delas também compositoras) e da possível influência que acabaram por exercer sobre a maneira de compor desses autores. Uma situação bastante específica de conviverem compositores e intérpretes lado a lado, numa colaboração mútua. Os autores necessitavam de vozes que expressassem o arrojo de suas propostas, e a forte personalidade dessas vozes acabou por imprimir marcas nas composições. Esse estudo fala também das vozes masculinas desses cantores-autores, que igualmente possuem uma maneira bastante contundente de cantar.

\footnotetext{
${ }^{136}$ Possivelmente um de seus últimos trabalhos é a série de letras entregues ao compositor Sergio Molina para que os musicasse, e para que a cantora Miriam Maria interpretasse (parceria que foi concluída em 2009, com o lançamento do CD intitulado Sem pensar, nem pensar). Na maioria desses textos trata-se do "eu lírico" feminino. Falaremos dessas canções adiante, quando nos referirmos aos desdobramentos da obra de Itamar.
} 
Sobre esses usos diferenciados da voz Machado reflete, após considerar a ligação que ocorre entre a gestualidade vocal e as unidades linguísticas, em nível interpretativo:

\begin{abstract}
Podemos acrescentar a essa definição a ideia de que, embora o cantor lide sempre com o equilíbrio permanente dos diversos elementos articulados no cantar, muitas vezes o desejado é o desequilíbrio como expressividade dramática. O gesto vocal pressupõe a elaboração e domínio dos níveis físico e técnico, somados à compreensão dos conteúdos da canção. Por isso é particular e expressivo da capacidade técnica de cada intérprete. (Machado: 2011, p.72.)
\end{abstract}

Então, o que se pode encontrar de significados para a voz feminina na música de Itamar é a resultante desse jogo de forças entre os personagens, entre o que pensa o "narrador" Itamar e o "quê" e "como" respondem essas vozes, que ora são interlocutoras mulheres ora são simplesmente o eco do pensamento do personagem principal, seu alter ego. Haveria então, não somente uma visão de Itamar $^{137}$ sobre o feminino e sobre as mulheres como também a contestação ou aquiescência das vozes femininas que ajudam a propagar essa visão, pois estão inseridas na canção e têm força própria de interpretação e de interferência.

Ainda sobre o potencial que a voz possui, quando inserida na canção, ou seja, quando portadora de um texto, Machado complementa:

\begin{abstract}
No que compete, no entanto, à comunicação essencial da canção, o primeiro elemento a se incorporar é a voz do cantor. Primeiramente em seu aspecto mais natural que diz respeito às qualidades do timbre, capaz de expressar sozinho uma amplitude de significações e sentidos, e depois através das habilidades do cantor de explicar os conteúdos entoativos e interpretativos, estabelecendo um elo com as propriedades autorais, por vezes até evidenciando elementos que não haviam sido observados pelo compositor. (op.cit: 2011, p.41).
\end{abstract}

\footnotetext{
${ }^{137}$ Isto é, a visão do narrador, através da voz de Itamar. Nem sempre a visão da pessoa do autor ou escritor condiz com a "mensagem", pois se trata, naturalmente, de um espaço de ficção.
} 
Sobre a questão de identificar quem é o feminino e o que representa na música de Itamar, a poeta Alice Ruiz tem uma visão clara, tomando como referência a letra da canção Luzia (fig.28):

Luzia pode ser uma mulher, mas também o público, que ainda não o conhece, ou ainda a língua portuguesa, a lusa dos Lusíadas, que ainda o verá triunfar. Mas não é a língua-mãe, é a sogra: a mãe da amada; e essa amada pode ser a língua brasileira. Luzia é a primeira personificação da resposta ao "não".(RUIZ apud ASSUMPÇÃO: 2006, p.60)

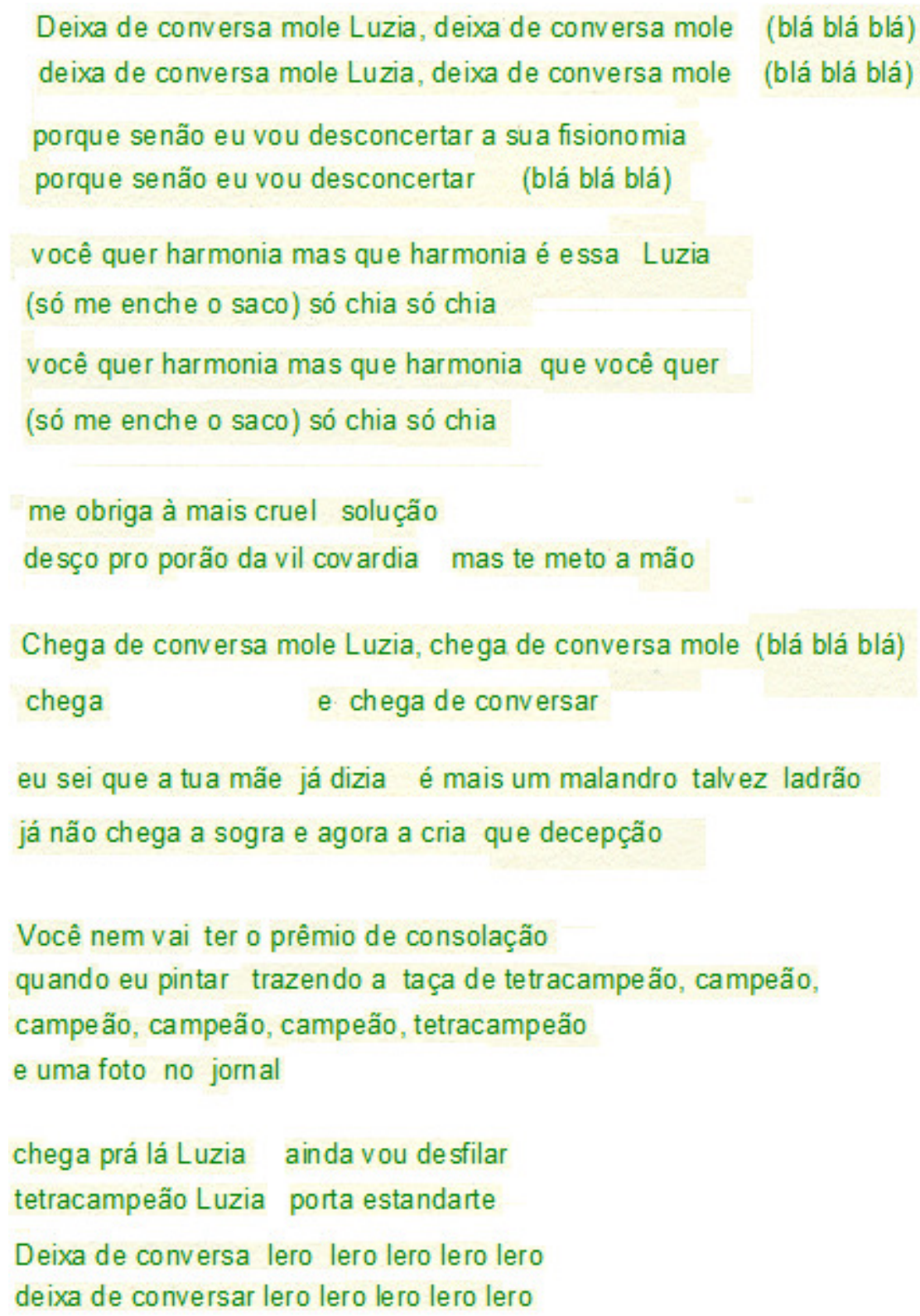

Fig. 28: Luzia, letra. (CD anexo faixa 13) 


\section{Quem canta seus males espanta}

Entro em transe se canto

desgraça vira encanto meu coração bate tanto

sinto tremores no corpo

direto e reto suando gemendo re sfolegando

eu me transformo em outras determinados momentos

cubro com as mãos meu rosto sozinha no apartamento

Ás vezes eu choro tanto

já logo quando levanto tem dias fico com medo

invoco tudo o que é santo

e clamo em italiano "ó dio come ti amo!"

eu me transmuto em outras determinados momentos

cubro com as mãos meu rosto sozinha no apartamento

Vivo voando voando

não passo de louca mansa cheia de tesão por dentro

se rola na face o pranto

deixo que role e pronto meus males eu mesma espanto

eu me transbordo em outras determinados momentos

cubro com as mãos meu rosto sozinha no apartamento

É pelos palcos que vivo

seguindo o meu destino é tudo desde menina

é muito mais do que isto

é bem maior que aquilo sereia eis minha sina

eu me descubro em outras determinados momentos

cubro com as mãos meu rosto sozinha no apartamento

É pelos pacos que vivo

è pelos pacos que vivo

Fig. 29: Quem canta seus males espanta, letra. (CD anexo faixa 22) 
A canção Quem canta seus males espanta (fig.29) é interpretada pela cantora Ná Ozzetti. A letra, em primeira pessoa, expõe um pouco do que seria o ofício de cantar, e da função que há no canto. Nesse sentido a cantora Ná toma para si palavras que são do poeta Itamar, e que lhe atribuem sentimentos e sensações. Mas sendo uma voz feminina, é simbolicamente o feminino quem passa a dizer. Várias imagens do poema se remetem às questões explicitadas por Itamar quanto à função do trabalho artístico: cantar é similar a um trabalho espiritual, já que se entra "em transe" ou; cantar modifica o estado das coisas, já que a "desgraça" vira "encanto"; a voz "transmuta", multiplica, pois há a transformação, o transbordamento de "uma" em "outras"138; cantar é um trabalho solitário, é uma "sina", tal qual a sereia, que não é daqui e nem de lá. É pelos palcos que se vive. A voz de Itamar aparece na gravação para concordar dizendo: "eu também". Por isso o feminino e o masculino podem ser vistos na obra de Itamar também de maneira profusa na mediada em que há o intercâmbio de papéis ${ }^{139}$.

Há canções compostas para mulheres reais, tal como $Z$ da questão (para Zena), Tetê tentei ( para Tetê Espíndola), Sonhei que viajava com você (para Cássia Eller), Orquídeas e Agora é que são elas (paras as Orquídeas do Brasil: Tata Fernandes, Miriam Maria, Lelena Anhaia, Simone Julian, Simone Sou, Georgia Branco, Adriana Sanchez, Clara Bastos) além de citações dos nomes de várias delas, sempre num contexto de valorização, tal como, Alice Ruiz, Elis Regina, Alberta Hunter, Clementina de Jesus, Elke maravilha, Vera Fischer, Irmã Dulce, Marlene Dietrich, Dóris Giesse, Violeta Parra, Alzira Espíndola, Daúde. Além disso, o fato de ter optado por trabalhar com musicistas mulheres, a partir dos anos 90 .

\footnotetext{
${ }^{138}$ Na gravação há sempre abertura de voz nas frases "eu me transbordo em outras", "eu me transformo em outras", "eu me transmuto em outras", "eu me descubro em outras", como se houvesse de fato a multiplicação da presença da voz. A própria cantora é quem dobra a melodia em uníssono durante toda a música deixando latente a presença de uma segunda voz. E nesses momentos de abertura, uma das vozes (gravadas por ela mesma) se desloca para terça abaixo para aí sim apresentar o desdobramento.

${ }^{139} \mathrm{Na}$ canção Nega Musica, por exemplo, além de haver a mistura de duas melodias, numa espécie de cânone em que Itamar e Neusa Pinheiro cantam, há no final a troca de região (de altura) aonde a voz feminina vai para o grave e a voz masculina canta no agudo. "Ela toca o fundo do teu coração, assim como uma mulher", diz a letra.
} 


\section{Amanticida}

A canção Amanticida (fig.30), composta em parceria com Marta Rosa Amoroso, ilustra as observações feitas sobre o fato de que a presença do feminino, na música de Itamar, funciona como indicador de que as questões da vida possuem inúmeras contradições, a permanência e a impermanência das situações e das coisas, amor e ódio, aquele que cuida de seu amado, e aquele que o mata. "Amanticida", explica ao final, é a amada que mata o amante. Quando o "feminino" aparece, o "masculino" perde sua própria referência e tem que se adaptar. E nesse sentido o feminino é muitas vezes visto como algo exógeno. $\mathrm{O}$ arranjo dessa canção, gravada ao vivo no disco As próprias custas $S . A$. cria diversos espaços de silêncio, conforme já observamos, e dentre eles aqueles que favorecem a interpretação e a performance. Numa fala inicial improvisada Itamar reforça (ou direciona) o significado da letra dizendo: "A gente nasce, vai crescendo até atingir a adolescência. Começa um fogo por dentro que vai queimando e uma inexplicável e violentíssima atração pelo sexo oposto. Daí até a morte é um Deus nos acuda." 
Eu vivo tentando saber porque o teu bem-me-quer de mulher

me mata, me acende quando você bem entende

me arrasta daqui pra ba Bagdá me empurra pra lá me puxa pra cá

me agita me sacode você me deixa até grogue

emito intré pidos grunhidos de ih

emito intré pidos grunhidos de felicidade dgi dgi dgi dgi

Me masca estica tira o doce depois me cospe

me liga, me de sliga liga lâmpada de poste

Me bate três vezes por dia me bate forte mais dez de noite

provoca esquizofrenia tento que me bate

me dá pontapés me dribla pra lá parece Pelé no Morumbi, Maracanã, Pacaembu

escracha roga praga enrosca mete a boca

me rasga a roupa louca vampira amanticida fera bruxa madrasta

Amanticida (bicha, sapatão)

(amanticida amanticida amanticida)

Amanticida amanticida,

amanticida (homem, mulher )

Amanticida amanticida,

amanticida (amada que mata amante)

(amanticida amanticida amanticida amanticida)

Fig. 30 Amanticida, parceria com Maria Rosa Amoroso. (CD anexo faixa 23)

\subsection{Contrabaixo e fala ritmada: quem é quem?}

É possível constatar, como a composição de Itamar está impregnada de ritmo, não só pelas referências já citadas, da relação com a cultura africana e brasileira, personificados no instrumento contrabaixo, como também pela 
obviedade que a própria escuta nos traz. Observam-se como muitas das construções melódicas compostas para a voz possuem tessitura restrita e notas repetidas ${ }^{140}$, chegando até em situações onde não há alturas e sim as entoações da própria fala ${ }^{141}$. Por isso, ocorrem gradações de melodias que possuem essas características de pouca movimentação melódica e muita subdivisão rítmica, até chegar àquelas que possuem somente os fonemas das palavras tal como o rap ${ }^{142}$. Sob certo ponto de vista poderíamos dizer que há semelhanças entre o tipo de fraseado do contrabaixo e essas construções melódicas. Não significa que haja intenção de que a voz seja uma imitação dele. Essa característica ocorreria porque o compositor tem uma maneira recorrente de expressar o ritmo, e esse modo acaba se manifestando não só no contrabaixo, mas nos outros os instrumentos e também na voz. Como, para Itamar, o contrabaixo se tornou o emissário dessa expressão (rítmico-melódica) aparentemente é desse instrumento que se irradiam as ideias rítmicas para os outros instrumentos. No entanto trata-se de um mesmo tipo de pensamento sendo expresso com diferentes roupagens ${ }^{143}$.

Podemos identificar três tipos de situações, em princípio, em que as melodias refletem explicitamente ideias rítmicas:

(1) aquelas onde a melodia se assemelha a uma linha de baixo;

(2) aquelas onde uma base instrumental serve de apoio à poesia, que é recitada de maneira ritmada, tal como o rap; e ainda

(3) aquelas em que o texto é falado de maneira livre, desvinculado, do ponto de vista da métrica musical, ao que ocorre com a base.

1) Linha de baixo e melodia semelhantes.

\footnotetext{
${ }^{140} \mathrm{Na}$ Missa in Memoriam, composta por Arrigo para Itamar, o segundo movimento contém trechos que evocam essa característica, também notada por Arrigo.

${ }^{141}$ Mas a manifestação dessa fala não é imitação da fala coloquial (no que diz respeito à vocalização, e não ao texto), do dia a dia. É uma fala que se coloca pulsando, auxiliando o trajeto do fluxo rítmico, apontando uma direção para o texto, que se acopla a esse pulsar, extraindo das palavras seu aspecto rítmico.

${ }^{142}$ Sigla para Rhythm and Poetry.

${ }^{143}$ Ainda assim não nos esqueçamos das canções com melodias líricas, e que nada tem a ver com esses procedimentos composicionais.
} 
Há semelhanças entre a linha de baixo e a melodia, através das seguintes características presente em ambas: tessitura pouco extensa, repetição de notas, vinculação da melodia à notas dos acordes, afirmação da pulsação. Um exemplo é a canção Beijo na boca (fig.31):
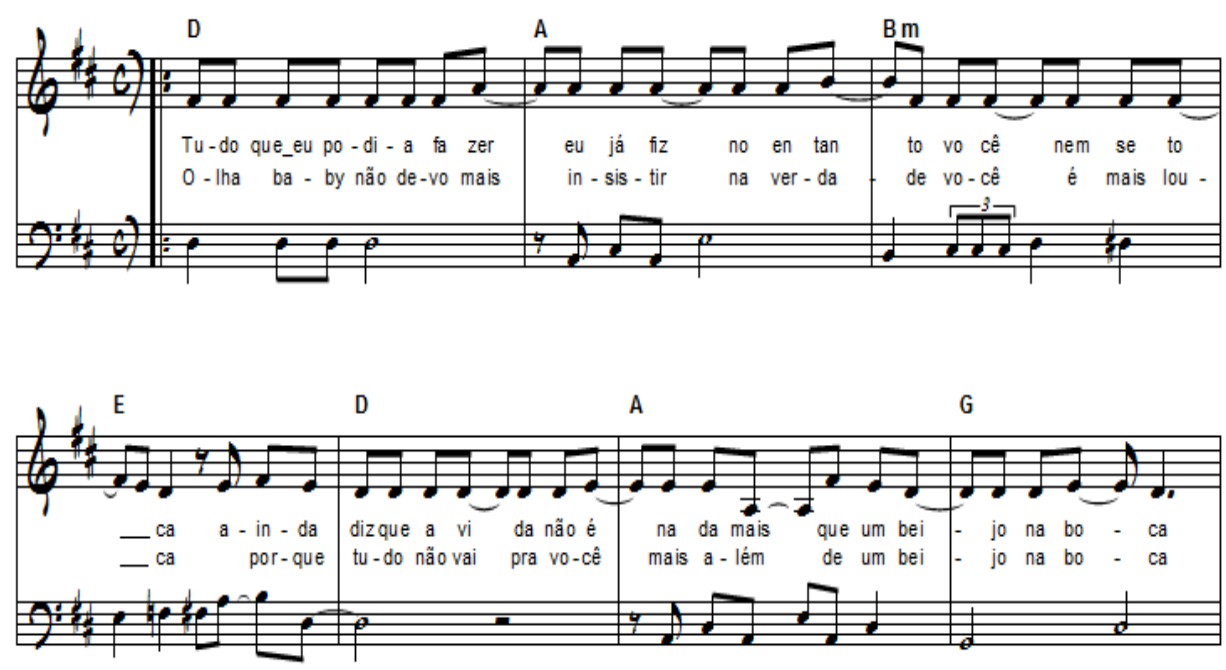

Fig. 31: Beijo na boca. Melodia com características semelhantes à condução de uma linha de baixo. (CD anexo faixa 24)

Ocorrem, nesta melodia, saltos que reforçam as notas das tríades dos acordes. Entre esses saltos não há notas de passagem, cromatismos ou notas da escala. É utilizada a repetição de alturas, fato que chama a atenção para a divisão rítmica e que imprime o predomínio dessa característica específica, que poderia ser considerada triádica, ligada aos arpejos.

Podemos considerar que esse tipo de perfil melódico encontra-se também em outros tipos de canções, como nos rocks da Jovem Guarda, por exemplo. Informalmente Itamar falava do movimento (e as vezes tocava algumas das canções), pois o vivenciou como todos os ouvintes da época que tinham acesso aos meios de comunicação. Esta canção Beijo na boca lembra um pouco esse tipo de rock, que traz um "ar" de Roberto Carlos e Erasmo com Elvis Presley, mas que não chega a possuir a força e a profundidade na poesia e na composição, tal como se verifica em outras de suas composições. Como se verifica também, nesse mesmo trecho escolhido da canção Beijo na boca (fig.31), a linha de baixo difere da melodia. $O$ fraseado de baixo funciona, segundo já verificamos em nosso estudo, como contraponto e apoio, na 
medida em que auxilia a balancear a melodia. Portanto, quando nos referimos à semelhança da linha de baixo com a melodia, não queremos apontar que haja o parentesco entre as duas na mesma canção. Mas sim argumentar que se a melodia da voz fosse tocada por um contrabaixo, poderíamos crer que ela cumpriria o papel de uma condução. Esse é o caso dessa canção.

Em outras duas canções há semelhança entre a melodia do refrão e a condução de linha de baixo, respectivamente encontrada em Baby e Santo de casa:

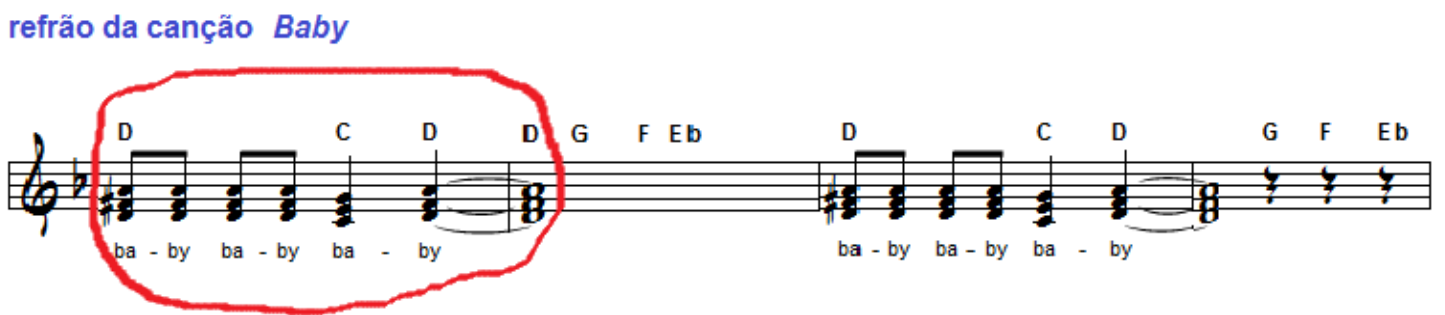

linha de baixo da canção Santo de casa

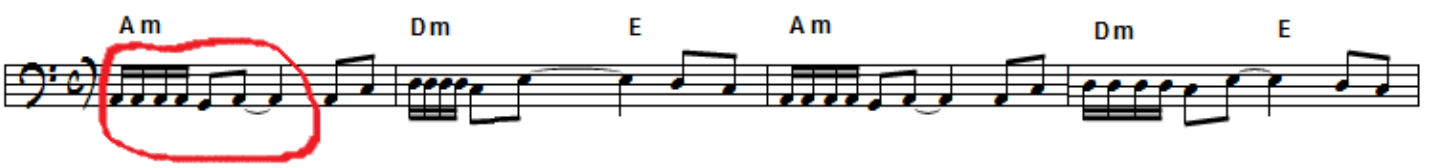

Fig. 32: Baby e Santo de casa, respectivamente refrão e linha de baixo. (CD anexo, faixas 25 e 26)

A semelhança ocorre independentemente da diferença de andamento, que implicou, para a escrita, na adoção de colcheias no primeiro caso e de semicolcheias no segundo. O motivo rítmico e o contorno melódico são os mesmos (fig.32).

Outro exemplo de melodia com características predominantemente rítmicas, semelhantes a uma condução de linha de baixo, é a da própria canção Santo de casa (fig.33): 

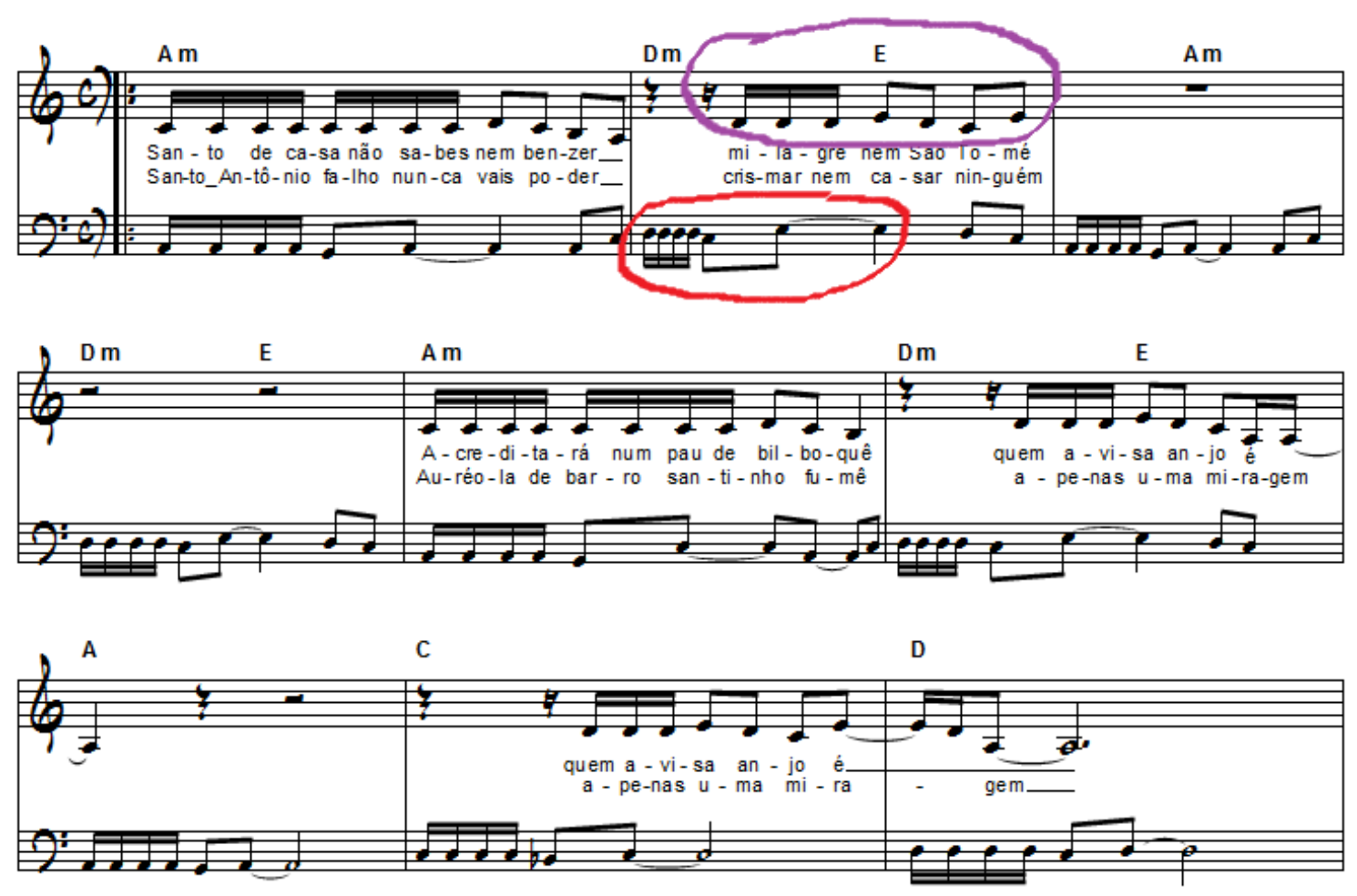

Fig. 33: Santo de casa, melodia e linha de baixo. (CD anexo faixa 26)

No trecho da melodia, assinalado em roxo, podemos encontrar semelhança com linhas de baixo de reggae, pois é reforçado, através da melodia, o terceiro tempo do compasso (como é típico do gênero). Utilizandose de pausa é criada uma suspensão que direciona a frase para esse terceiro tempo, tornando-o forte. Além disso, a melodia inteira se desenvolve por módulos curtos, que se repetem ou sofrem pequenas variações, apoiando-se em notas dos acordes. Eventualmente, canções com características mais melódicas apresentariam frases com ciclos mais extensos, com divisões rítmicas mais soltas, com utilização de notas com maior duração de tempo, além de relações intervalares escalares (mais do que ligadas a arpejos), como seria o exemplo de outra canção do próprio Itamar, Nega música (fig.34): 


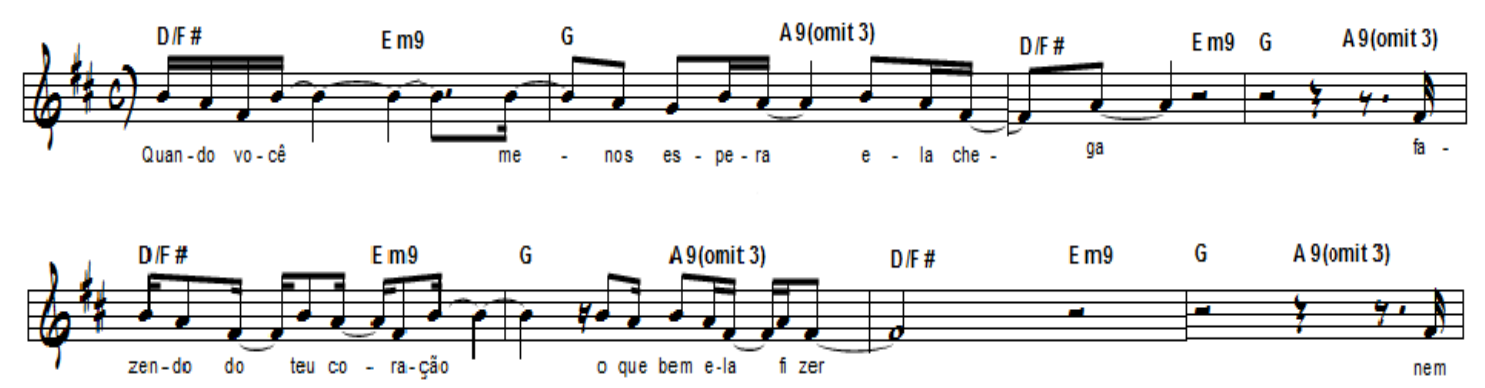

Fig. 34: Nega música, melodia. (CD anexo faixa 27)

Voltando à canção Santo de casa (fig.33), observamos ainda a busca do equilíbrio entre a melodia e a condução (assinalada em vermelho), uma vez que num primeiro momento a linha de baixo apoia a melodia reforçando-a, e em seguida intercala com ela os momentos de notas com duração mais longas e de notas com duração mais rápida e vice versa.

2)Texto rítmico.

Há algumas canções onde todas as palavras do texto, da poesia, são pronunciadas sem melodia. No entanto, como já observamos, essas palavras não são ditas buscando espelhar a entoação da fala. São pronunciadas de modo a transformar o texto num elemento musical, através uso da voz. O texto passa então a agregar, além de seus possíveis significados poéticos, um sentido musical que o atrela à instrumentação e à base e que interfere sobre esses mesmos significados poéticos. E nesse sentido haveria certa "imitação" do ato da fala, uma "representação" da mesma, provocando um sutil distanciamento que nos faria ao mesmo tempo nos reconhecer na ação e entender de que se trata uma "simulação", da criação de um espaço de ficção.

Exemplificando, temos Venha até São Paulo (fig. 35): 


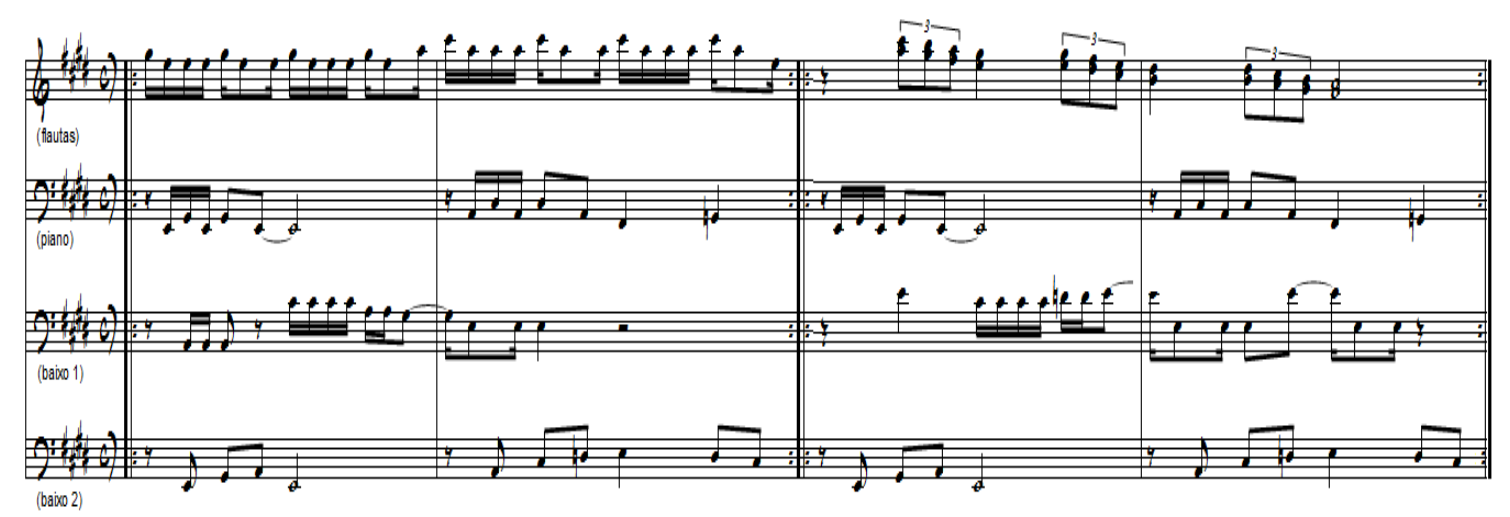

Fig. 35: Venha até São Paulo, base modular. (CD anexo faixa 17)

Sobre essa base modular mostrada anteriormente é dito o texto, de maneira ritmada, como o rap:
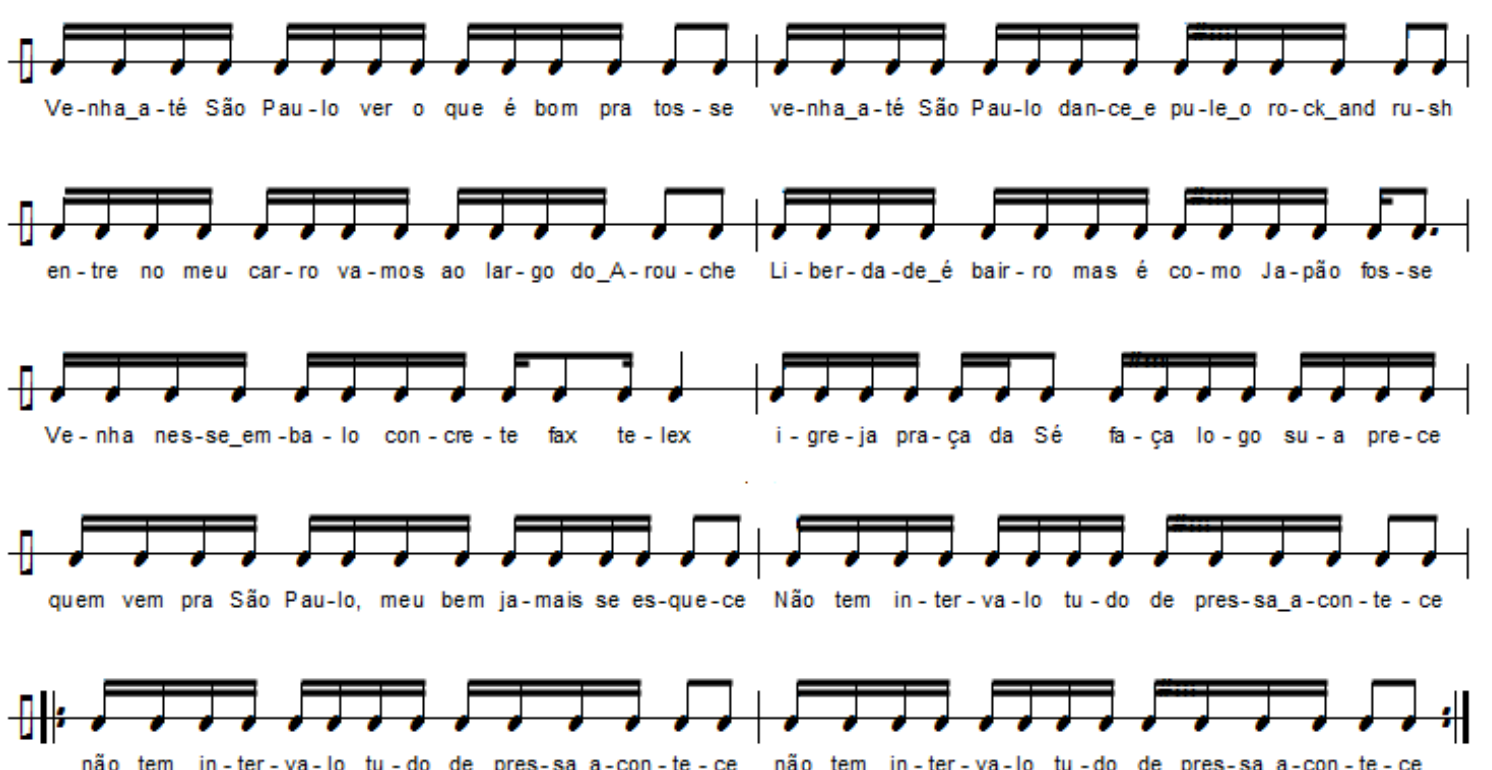

não tem in-ter-va-lo tu-do de pres-sa_a-con-te-ce não tem in-ter-va-lo tu-do de pres-sa_a-con-te-ce

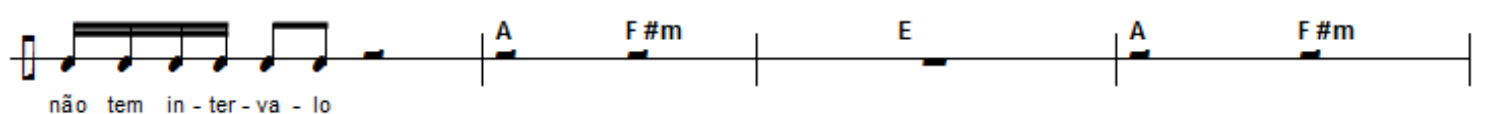

Fig. 36: Venha até São Paulo, rap. (CD anexo faixa 17)

O adensamento do espaço sonoro, através da ausência de pausas (com curtos momentos onde o cantor pode respirar, (fig.36), pode ser entendido como alusão ao adensamento populacional da cidade, à poluição sonora e visual, como uma releitura da premissa de que "São Paulo não para". Quando termina a frase "não tem intervalo", é então que ele ocorre para o ouvinte, e a 
prosa cessa. Na gravação o texto é "cantado" por Rita Lee e Itamar, além das Orquídeas do Brasil. Essa mesma base instrumental serve de apoio para outro texto, É tanta água (desta vez cantado por Tom Zé), que também acaba se referindo à cidade de São Paulo, lugar que é tão presente nas reflexões de Itamar, direta e indiretamente.

A canções Reengenharia (em parceria com Sergio Guardado), e Olho no olho (em parceria com Vange Milliet) do disco Pretobrás I, também são temas falados sobre uma base. Essas composições apresentam um traço de semelhança com o hip-hop quando, além da fala ritmada, ocorrem refrões com melodias intermediando as falas em prosa. É também o caso de Cultura Lira Paulistana (fig.37):
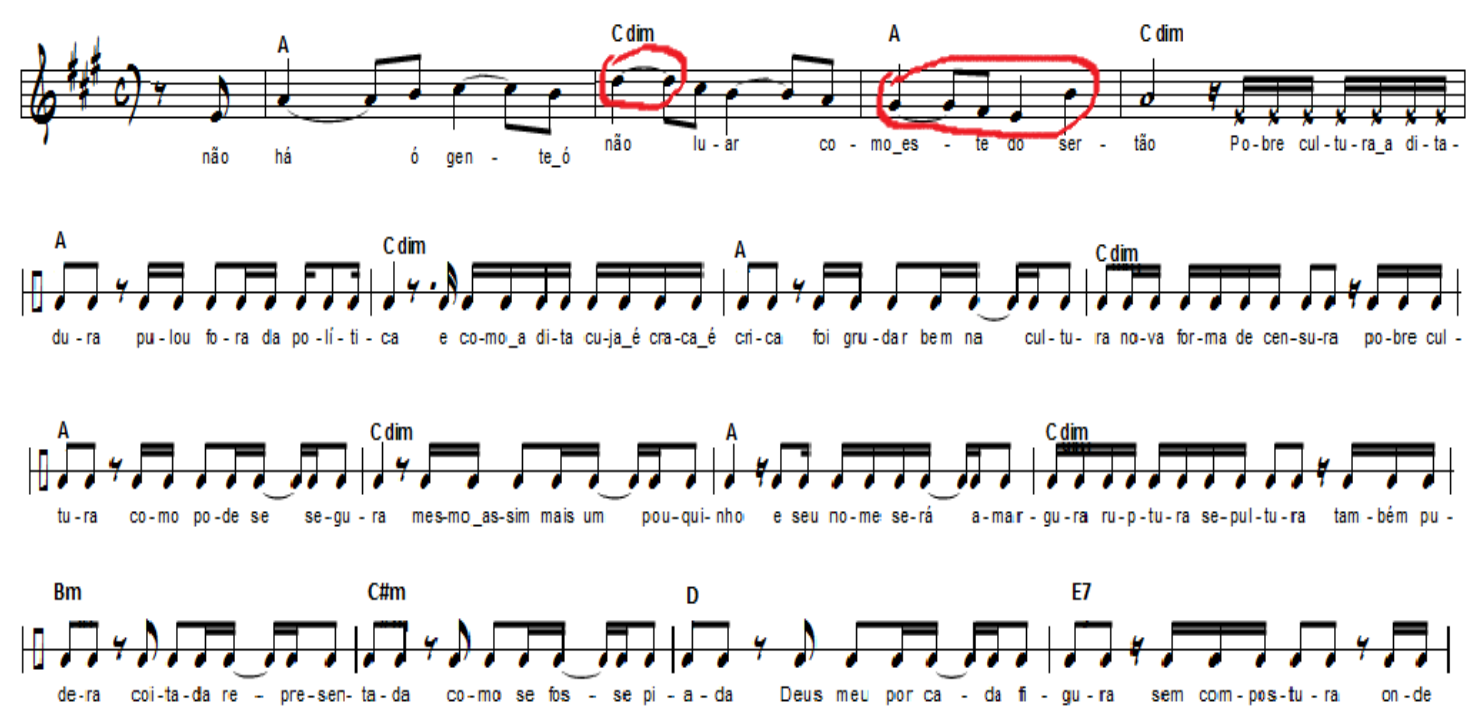

Fig. 37: Cultura Lira Paulistana, fala ritmada com melodia. (CD anexo faixa 28)

A melodia adotada para o refrão é uma citação da canção Luar do Sertão ${ }^{144}$. A sequencia harmônica desse trecho inicial (da introdução) está em conflito com a melodia. No trecho assinalado (fig.37), no compasso 2, o acorde original utilizado seria o de mi maior. Ao optar por Do diminuto e Lá maior (expressos pela linha de baixo e pelo teclado) ocorrem dissonâncias não esperadas para o que seria um tema bucólico. Principalmente no primeiro

\footnotetext{
${ }^{144}$ Composição atribuída a Catulo da Paixão Cearense e João Pernambuco (SEVERIANO e MELLO: 1998, p.38).
} 
acorde, quando a melodia se detém na nota ré, meio tom abaixo do mi bemol presente em Do diminuto.

Mais um exemplo de canção com fala ritmada e refrão com melodia é a canção Orquídeas (fig.38):

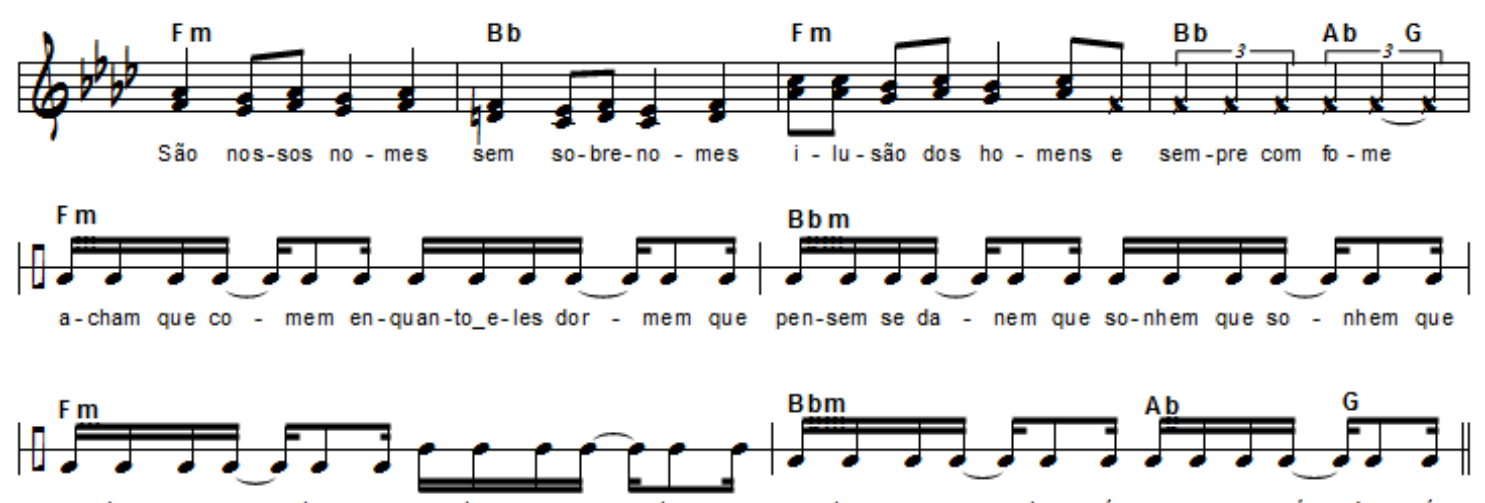

Fig. 38: Orquídeas, fala ritmada e melodia para o refrão. (CD anexo faixa 29)

Esse tipo de construção permite que a composição ofereça momentos de respiração, onde a densidade prolixa do texto pode pausar por instantes dando tempo ao espectador de retomar o fôlego.

3) Texto livre

Sobre o texto dito de maneira livre, sem compromisso musical com a base, encontramos alguns exemplos. Podemos relacionar esse procedimento de composição à questão da teatralidade e performatividade buscadas pelo autor. Há diversas canções onde uma fala introduz a canção, como se fosse o entreato, a presença de um narrador que fornecerá parâmetros para o entendimento da cena ${ }^{145}$. Na canção Totalmente à revelia (fig.39) o texto é falado sobre uma base instrumental, que passa a ser pano de fundo, na medida em que não se estabelece nenhum vínculo direto entre ambos, apenas

\footnotetext{
${ }^{145}$ É o caso da abertura do show de gravação ao vivo de Às próprias custas S.A., das canções Luzia, Venha até São Paulo, Estrupício, Homem-mulher.
} 
o contraste, como se os sons da base fossem um paisagem sonora ocorrida ao acaso. É formada por três sessões, três bases diferentes ${ }^{146}$.

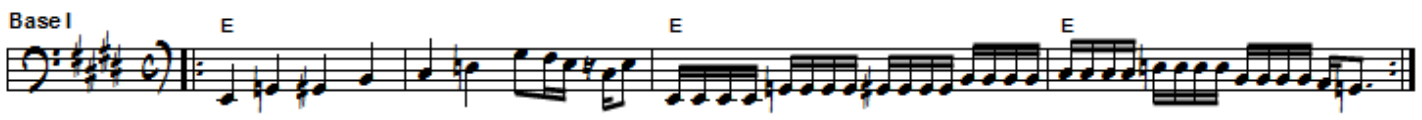

São três horas da manhã já do outro dia, eu pensando no futuro enquanto você dormia, se eu morresse amanhã qual que será qual que seria

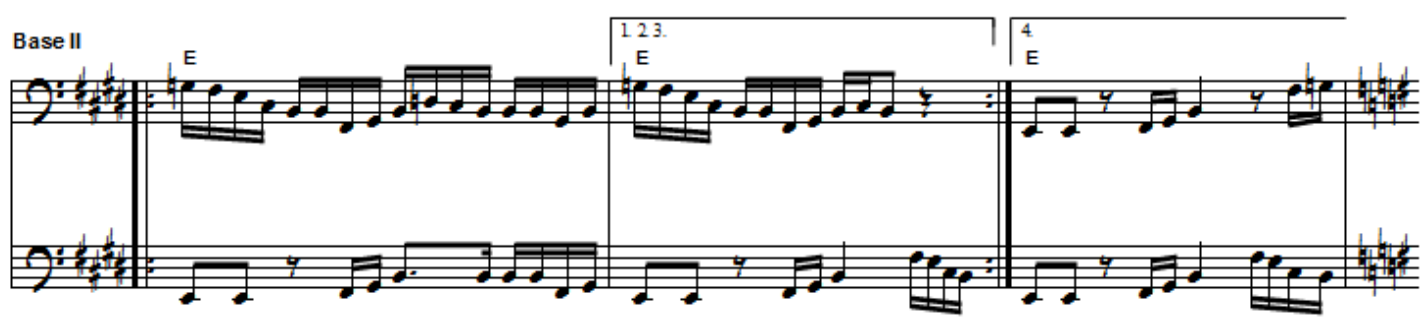

Enquanto você dormia de batom turquesa sabor cereja, deusa ou o que quer que seja, sono que é bom não me vinha, vinham-me somente dúvidas

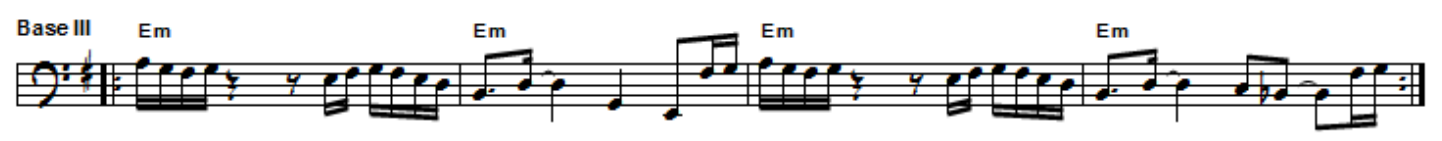

Porque será que a vida só tem caminhos de ida, tchu ru ru ru ru ru, tchu ru ru ru ru, ru ru, ru ru

Fig. 39:Totalmente à revelia, canção com texto sem vínculo com a base. (CD anexo faixa 30)

\section{Compromisso com o ritmo}

É importante resgatar uma reflexão a respeito do vínculo que uma melodia entoada, ou poema recitado podem possuir com uma base instrumental de acompanhamento. Tratando a respeito de processos interpretativos na canção popular a pesquisadora Marta Ulhôa propõe o que chama de "métrica derramada" (1999) ${ }^{147}$. Esse conceito foi formulado, segundo a autora, observando características ocorrentes na canção brasileira, principalmente no samba, onde acontece o deslocamento rítmico entre o canto e o acompanhamento. Assim formula o conceito:

\footnotetext{
${ }^{146}$ Sobre a gravação desse LP Sampa Midnight, o contrabaixista e produtor Paulinho Le Petit conta, em entrevista anexa, como por questões de limitação técnica da época, e por terem ocorrido desentendimentos entre Itamar e os músicos, bateria e trombone foram gravados ambos, após os violões, apenas em um canal de áudio, o único restante para a finalização.

${ }_{147}$ Conceito de métrica derramada apresentada no artigo: Métrica Derramada: tempo rubato ou gestualidade na canção brasileira popular.
} 
A noção da métrica derramada tem a ver com a relação entre o canto e o acompanhamento, onde o canto - regido pela divisão silábica prosódica de língua portuguesa - e o acompanhamento - regido pela lógica da métrica musical - parecem às vezes "descolados" um do outro, numa sincronização relaxada. [...]

Na métrica derramada ocorre uma superposição da divisão da divisão das sílabas e o encaixe frouxo dos padrões de acentuação da língua portuguesa à brasileira aos compassos musicais regulares da tradição ocidental consagrada. (ULHÔA:1999, p.2)

Observamos que na música de Itamar, embora haja a preocupação enfática com a prosódia ${ }^{148}$, não predominam interpretações onde aparecem esses deslocamentos. Ou ele está vinculado à base, ou se apresenta livremente. Conforme propõe Ulhôa esse fenômeno de defasagem ocorreria a partir de um descomprometimento rítmico da melodia (entoada pela voz) com a base instrumental em prol de se enfatizar questões de prosódia e interpretativas. O deslocamento seria seguido por uma retomada para 0 acoplamento de ambos, tratando-se, portanto de momentos específicos.

Mas se essa característica não é predominante na obra de Itamar, a levantamos aqui exatamente pelo motivo de que em suas composições e interpretações ocorre o oposto. Na música de Itamar a melodia possui um comprometimento rítmico com a base. A melodia da voz expressa informações rítmicas que são complementares às dos outros instrumentos. Assim as frases musicais constituem uma rede de pulsações onde o status da melodia é equivalente ao do acompanhamento, pois atuam como parte de um mesmo corpo. Ao lembrarmo-nos do conceito de Ulhôa pretendemos afirmar, mais uma vez, o quanto está presente a característica de horizontalidade na obra de Itamar, que não isola a melodia do restante, mas a emaranha com as frases dos outros instrumentos através do trabalho rítmico. E sob esse aspecto o que estaria na condição de "derramamento" seria a ideia de compasso, conforme já pudemos verificar $^{149}$.

Quando a melodia não cabe nos compassos para onde foi destinada ocorre uma adequação rítmica, acelerando a pronúncia das sílabas para

\footnotetext{
${ }^{148}$ Além da dicção e da interpretação do texto.

149 Quando nos remetemos à questão das características da música africana que foram absorvidas na música de Itamar, e podem ser verificadas através das frases modulares e das defasagens de quadraturas nas mesmas.
} 
encaixá-las em figuras rítmicas mais rápidas. Há situações onde o texto é prolixo, porque de fato as palavras não caberiam no tempo (nos compassos) se fossem pronunciadas normalmente. E há situações onde o texto é apressado em determinadas palavras para entrar num andamento mais largo em seguida. Ambos os procedimentos geram um efeito interessante, pois não retiram o significado semântico das palavras. À elas agregam a exploração de suas características musicais dando outra perspectiva para os significados do verso. Um exemplo disso está no arranjo feito por Itamar para a canção de Ataúlfo Alves, Laranja madura.

O refrão expresso pelos vocais enfatiza o sujeito da frase, "laranja madura na beira da estrada, tá bichada Zé, ou tem marimbondo no pé", na medida em que pronuncia a primeira frase do texto de maneira acelerada. $\mathrm{Na}$ gravação original esse refrão ocorre em oito compassos de $2 / 4$, ou quatro compassos de 4/4 (fig.40) (já que Itamar não utiliza a fórmula de compasso do samba). Na versão de Itamar, ao final reduz o espaço compactando-a em dois compassos, e altera a sequência harmônica e a melodia. Para que toda a frase de texto caiba nesses dois compassos a pronúncia de algumas palavras é acelerada $^{150}$. Assim, parece que o arranjo quer induzir-nos a concordar com a questão colocada: das duas uma, se encontrarmos uma laranja madura na beira da estrada necessariamente estará estragada seja por estar infestada por bichos ou pela presença de marimbondos na árvore. $\mathrm{O}$ arranjo parece reforçar a mensagem da letra que não vê possibilidade de um acontecimento positivo ocorrer sem explicação, de forma gratuita, como decorrência do acaso.

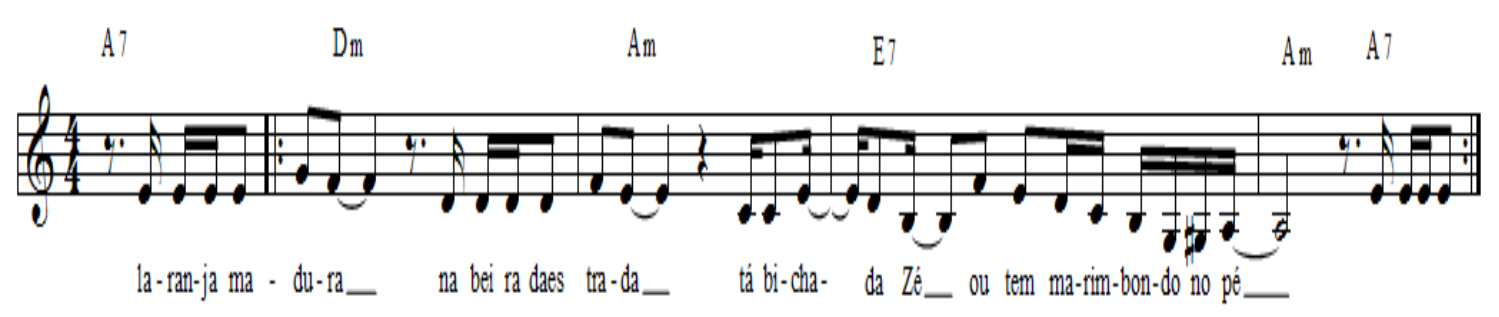

Fig. 40: Laranja madura, refrão original da canção de Ataúlfo Alves, arranjada por Itamar Assumpção. (CD anexo faixa 31)

\footnotetext{
${ }^{150}$ Verificaremos adiante como o compositor Sergio Molina solucionou musicalmente a questão da prolixidade do texto e da ausência de métrica nos poemas que Ihe foram entregues por Itamar para musicar, no projeto que foi intitulado Sem pensar nem pensar.
} 
A aceleração do refrão ocorre da seguinte maneira através dos vocais, imprimindo uma nova informação rítmica e melódica em relação ao original (fig.41):
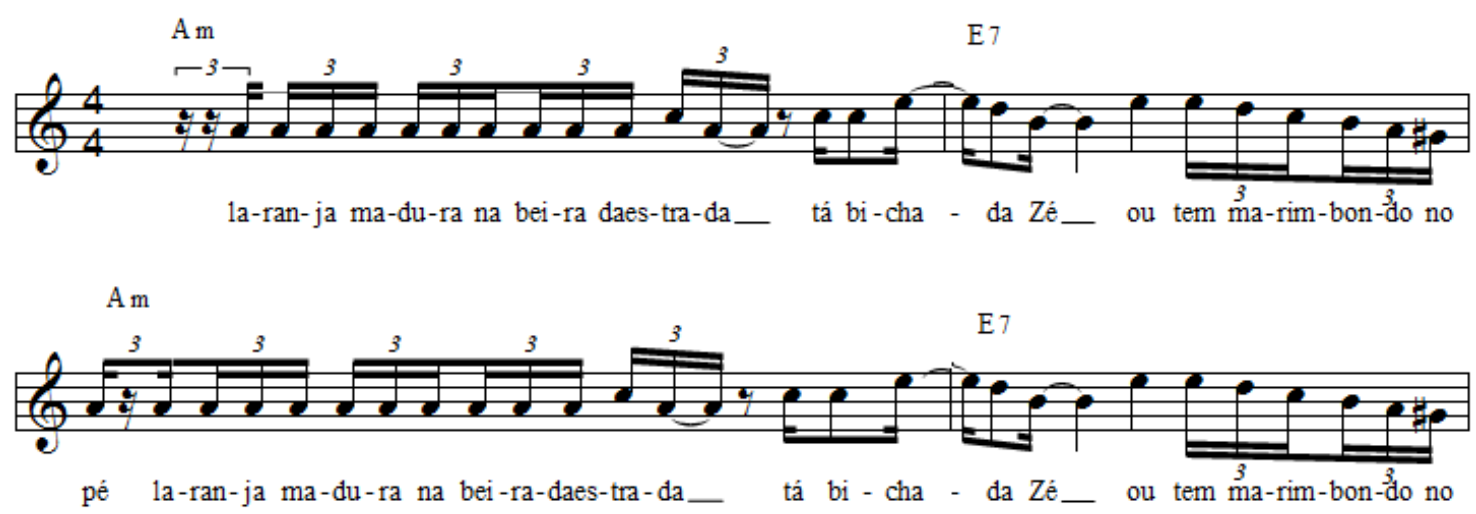

Fig. 41: Laranja madura, refrão rearranjado.

$\mathrm{Na}$ canção Nego Dito, outro exemplo, observa-se a afirmação da pulsação através da construção melódica, que permanece atada à ela, e por isso parece garantir uma característica enfática ao discurso. Trata-se da auto descrição de Nego Dito, que fala em primeira pessoa. Se suas palavras fossem pronunciadas de maneira fluida o caráter incisivo do texto não teria o mesmo efeito. O ritmo precisamente cantado (fig.42), e construído com subdivisões de tempo (colcheias) da pulsação principal torna o canto enfático e contribui para caracterizar o personagem Beleléu, como sendo alguém que age impondo seu comportamento.

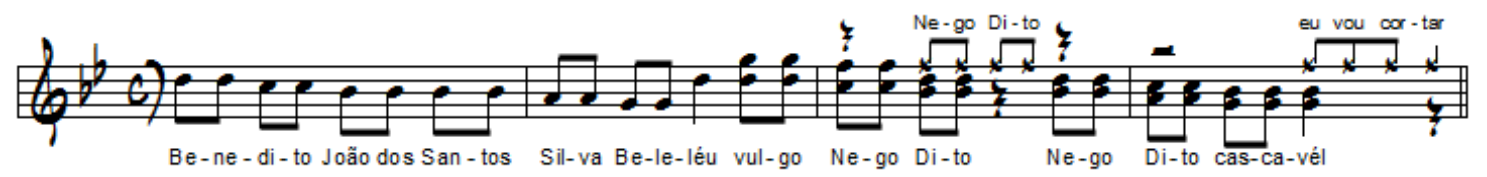

Fig. 42: Nego Dito, introdução. (CD anexo faixa 7)

As remasterizações e reprensagens em $C D$, posteriores à edição original do LP Beleléu, excluíram da faixa Nego Dito parte dos vocais, que 
exemplificam, tal como o exemplo de Laranja madura, a utilização do recurso do aumento da subdivisão rítmica para que uma frase extensa caiba em poucos compassos. No arranjo vocal, que consta no vinil de 1980 (fig.43), com efeito de cânone, há várias vozes que vão sendo acrescentadas aos poucos. Há algumas linhas que são repetidas e alguns trechos improvisados. O personagem Beleléu, através da voz de Itamar, utiliza uma fala sussurrada, e que devido a seu conteúdo assume caráter de ameaça. O acréscimo dos vocais gera aos poucos o aumento da dinâmica e da tensão discursiva. Mesmo com a utilização de contratempos fica clara a afirmação do pulso:

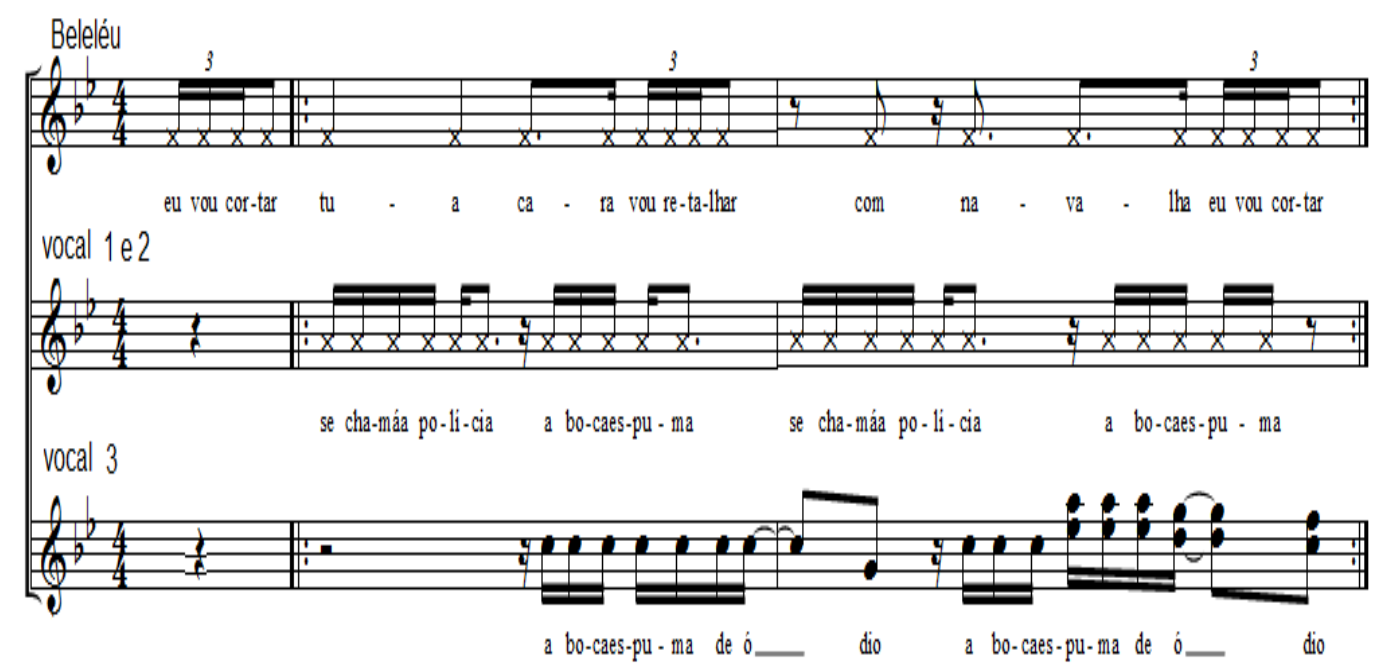

Fig. 43: Nego dito, arranjo vocal. (CD anexo faixa 7)

$\mathrm{Na}$ foto do encarte (tanto deste LP como dos CDs que foram reprensagens do disco original), está mais um dado que pode ajudar a explicar a insistente associação que ligava o personagem Beleléu à pessoa do compositor Itamar Assumpção. Em princípio essa associação foi intencionalmente provocada por Itamar, mas com o passar do tempo essa "mascara" passou a the incomodar já que as sutilezas de seu trabalho ficavam obscurecidas por uma imagem pré-concebida. Na foto do encarte há a sobreposição da imagem de uma navalha sobre o título de eleitor do próprio Itamar. A navalha é objeto com o qual Beleléu faz as ameaças na canção. A voz que as profere é do próprio Itamar. Se a navalha está sobre um 
documento, possivelmente o nome que lá consta "identifica" quem é seu dono. A ficção e a realidade foram misturadas propositalmente pelo artista para a construção de um senso cênico. Mas a compreensão literal da situação, principalmente por parte da mídia, o aborrecia. "Maldito vírgula!" exclama na primeira faixa do CD Pretobrás II, que leva o mesmo título.

\subsection{Performatividade nas composições.}

À primeira vista, as composições que apresentam performatividade são aquelas onde aparecem de imediato os aspectos mais evidentes de teatralidade. Eles são identificáveis, por exemplo, no disco Às próprias custas $S . A$. que é a gravação de um show ao vivo, na sala Guiomar Novaes, na Funarte, em São Paulo, onde há a clara constituição de personagens que interagem. Poderíamos dizer que na gravação desse show ficou impressa, ao contrário de todos os seus outros trabalhos (que foram realizados em estúdio), um pouco da atmosfera do espaço cênico que Itamar conseguia criar através da presença e da relação com a plateia, ao vivo. Contudo a teatralidade, conforme já observamos, é um dos componentes da performance. Mas, mesmo em canções que foram só registradas em estúdio, sem a presença do público, é possível identificar o empenho do compositor em trazer a "tactilidade"151.

O fato de os meios eletrônicos, auditivos e visuais, haverem se estabelecido, fixando o registro da voz e da imagem, gerou diversos impactos sobre o uso e os significados da voz ${ }^{152}$, e sobre os modos de escuta. Dentre eles o fato de se abolir a presença daquele que traz a voz (a fonte sonora que origina o registro não precisa estar mais diante do ouvinte ou espectador - a esquizofonia, segundo Murray Schafer); de desvincular o tempo de transmissão do tempo cronológico da escuta ou visualização (qualquer registro pode ser escutado ou assistido em momentos diferentes daquele em que foi gerado, possibilitando a reiteração inclusive); e de se poder criar um espaço artificial, não real, redefinindo as referências espaciais da voz viva. Para Zumthor a

\footnotetext{
${ }^{151} \mathrm{Tal}$ como denomina Zumthor, para referir-se ao grau de performatividade (Zumthor: 2005, p.69 - 70; e Zumthor: 2000, p.17 -18).

${ }_{152}$ Segundo Michel Chion e Paul Zumthor (CHION, Michel, p.13-23,1997 e ZUMTHOR, Paul, p.17, 2000).
} 
"tactilidade" que existe na performance se relacionaria ao caráter de efemeridade que a ação ao vivo possui, e que os possíveis registros tenderiam a aboli-la ou a diminuí-la. Resgatamos essas questões para sugerir que a obra de Itamar possui caráter perfomativo intencional também nas composições, mesmo quando fixadas nos áudios dos CDs e nos registros em vídeo, independentemente de apresentações ao vivo, momento em que esses traços evidentemente se potencializavam de maneira extrema. $O$ argumento estaria no fato de que mesmo com todas as distâncias que se estabelecem com a mediação, ainda assim pode ser recriada a sensação de esvanecimento (ou de efemeridade) a cada escuta. Uma vez que a música acontece no tempo determinado e se finda dentro dele, e uma vez que cada escuta pode ser aprofundada no que concerne às impressões e sensações de quem ouve quando a reitera, haveria a manutenção da "tactilidade" mesmo que em menor grau.

\section{Adeus Pantanal}

Voltamos a um ponto importante que trata de refletir a respeito do quanto, na musica popular urbana e rural, os processos composicionais se completam durante a ação, durante a execução. Assim a composição guardaria em si um potencial performativo que passa a emergir através das diversas contribuições da ação de interpretação dos músicos no momento de uma gravação, de um show ou de uma apresentação na rua. De maneira que ao utilizar-se de recursos composicionais, de texto e de materiais e procedimentos musicais, o compositor (neste caso Itamar) não pode senão desenhar o esboço de alguns trajetos que serão ou não percorridos e expandidos na prática. $O$ grau de performatividade da composição seria então a sugestão desses caminhos que passam a ser ocupados.

A gravação da canção Adeus Pantanal (do disco Intercontinental quem diria! Era só o que faltava!!!) é um exemplo contundente de utilização da voz, feita de maneira a ampliar as significações do texto e da música. As vozes principais são de Tetê e Alzira Espíndola, (cantoras e compositoras, elas próprias nascidas na cidade de Campo Grande da região do Pantanal matogrossense, do qual fala a letra) e de Itamar. Em primeira pessoa o texto (fig.44) 
descreve todos os tipos de bichos, aves, peixes e plantas que, numa visita, não puderam ser vistos na natureza da região, porque estariam em vias de extinção - embora a própria palavra "extinção" não seja dita em nenhum momento. Fica subentendida a questão através do título da canção, e através da letra se referir sempre a algo que não pode ser visto. $O$ fato de não se ver aquilo que sempre foi nativo corresponderia ao fato de que esse "algo" desapareceu. Há na canção vocais que reforçam a frase: "vi quase nada". Além dos tipos de emissão vocal serem variados ${ }^{153}$, elas ocorrem num crescendo. Na medida em que vão sendo descritos os tipos de animais, os timbres de todas as vozes que participam gradualmente se transformam, tornando-se eles mesmos emissões similares às dos bichos. Os timbres se tornam gradativamente metálicos, anasalados, aerados, guturais, consonantais a ponto de não restarem mais palavras, mas somente os sons que rementem à paisagem sonora do lugar.

\begin{tabular}{|c|c|}
\hline Eu fui à Cuiabá pra no Pantanal olhar & a bicharada \\
\hline eu fui pra ver não vi que decepção senti & vi quase nada \\
\hline eu não vi bem-te-vi beija flor nem juriti & a passarada \\
\hline eu não vi jabuti não vi coral sucuri & vi quase nada \\
\hline eu não vi o quati não vi anta nem sagui & onça pintada \\
\hline
\end{tabular}

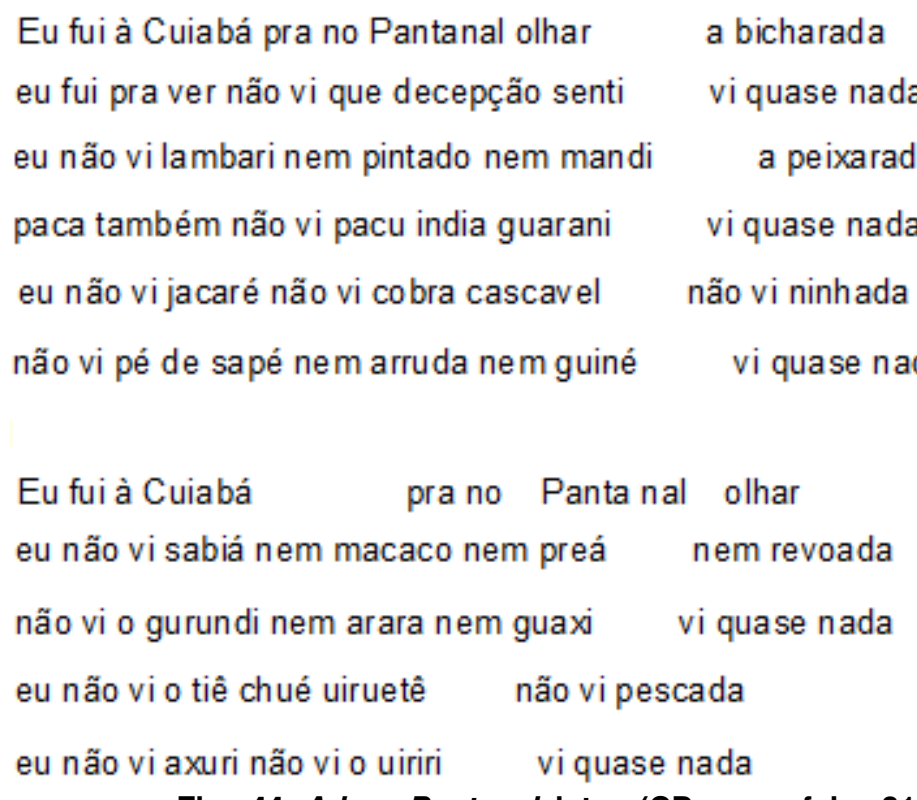

Fig. 44: Adeus Pantanal, letra. (CD anexo faixa 31)

\footnotetext{
${ }^{153}$ Regina Machado apresenta os vários tipos de "vocalidades" que servem como referência para o canto, e sobre tudo na expressão vocal ligada à canção brasileira (MACHADO: 2011, p.23)
} 


\section{Sexto sentido}

Há no arranjo e na gravação da canção Sexto sentido (fig.45) algumas características que parecem capturar o ouvinte para dentro de um ambiente específico. É criada uma sensação estranha, como se houvéssemos penetrado num lugar desconhecido sonoramente, e poeticamente. $O$ estranhamento parece dar-se também pela tomada de consciência desse ouvinte, que pode não identificar exatamente onde está. O grau de performatividade estaria aí, levando em conta outros aspectos que não só os cênicos (das representações), mas também os das percepções (das sensações) que a escuta suscita. A letra utiliza termos como o "sexto sentido", "mundo mandala", "rio da mente", "tempo tempera", "tecendo o futuro" que além de comporem imagens poéticas estão entrelaçados com um tipo de canto angustiado (cantado e interpretado pela voz de Denise Assunção). A voz de Denise parece ser emitida de um lugar diferente, é uma voz projetada - como atriz que de fato é, e que, estando no palco quer fazer suas palavras audíveis sem gritar. Sua voz parece ser emitida de um lugar além, como se não fosse advinda do mesmo espaço no qual "estamos" presentes. Algumas emissões "tremidas" exacerbam a ideia de angústia e aflição pelas quais parecem passar essa "voz" que não é identificável com pertencente a um personagem específico. O poema pode se referir a várias coisas, e estabelecer, naturalmente, seus diversos significados. Sobre o que se estaria falando de fato é a duvida. Há um canto "incontido", a necessidade de se descansar, uma luz e uma voz que não podem ser apagadas, um sexto sentido que guia essa voz, a transformação das coisas através do mundo mandala ${ }^{154}$. Pois a possibilidade de nos localizarmos, enquanto ouvintes, estaria relacionada à percepção de uma direção aproximada de atribuição de significados.

Não há introdução na gravação, todos iniciam junto, o que traz a "fala" para o primeiro plano. Ocorrem momentos pontuais de silêncio e um diálogo entre o a frase do contrabaixo e a condução da guitarra. Quando o contrabaixo termina a frase, inicia-se o riff de guitarra e vice-versa. Embora a canção apresente uma tonalidade clara há um movimento de acordes maiores em

\footnotetext{
${ }^{154}$ Seria ainda a recorrência da questão da função artística, sempre colocada por Itamar em conversas, de que ele tinha uma missão a cumprir, sendo artista, e que embora essa tarefa fosse difícil não haveria como renegá-la ou desistir?
} 
semitons, que criam a sensação de que se está num círculo, circundando a mandala, já que saem do centro para uma distância próxima e retornam para ele de maneira cíclica. Essa dinâmica de ação imprime um balanço que se mantem oscilando entre um instrumento e outro, oferecendo aqueles espaços de silêncio do qual já falamos, e que permitem ao ouvinte se fazer presente e interagir. "É preciso estar silêncio para eu não ficar aflito", diz a letra.
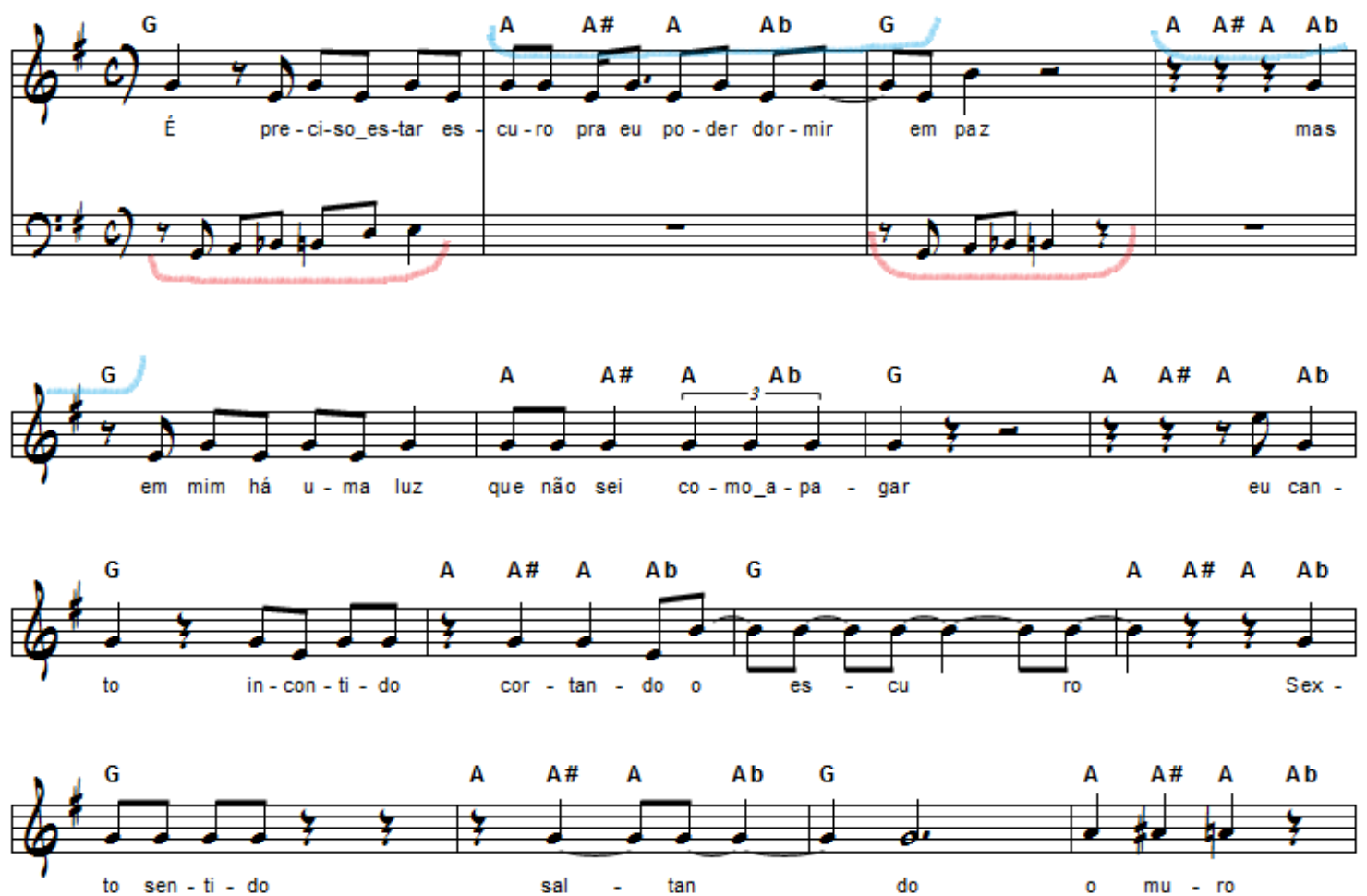

Fig. 45: Sexto sentido, primeira estrofe, frase de baixo alternando com condução de guitarra.

(CD anexo faixa 32)

\subsection{Letra e Música}

A denominação de "grande poeta não", conforme apelido dado por Alice Ruiz e Paulo Leminski a Itamar Assumpção, demonstra o território pelo qual o compositor sempre transitou, sem ter perfeita ciência de que já o fazia com passaporte livre. Itamar foi se conscientizando das próprias habilidades e desenvolvendo aos poucos essa sofisticação da escrita e, na mesma medida 
em que acordava para a importância da poesia, passou a dedicar-se a ela gradativamente, em detrimento de outros componentes de sua obra que já estavam estabelecidos. Enxergou na poesia uma grande possibilidade de ampliar seu fazer artístico enquanto que em relação à parte musical já havia estabelecido um estilo definido e com personalidade suficiente. Tanto é assim que seus últimos trabalhos são letras de canção, poemas. Passou a escrever vertiginosamente no fim da vida.

\begin{abstract}
Seus poemas curtos - ou de outros, mas escolhidos a dedo pela afinidade -, quase vinhetas, ganham status de letra em arranjos elaborados, ao repetir os poucos versos até eles calarem fundo, mostrando que tudo ali está dito. Esses poemas figuram ao lado de suas longas letras, elaboradas, complexas e contundentes, cada vez mais ricas em rimas e que fazem brotar da fala e das pequenas coisas do dia a dia a intensidade de um ser irritado e amoroso, rebelde e reverente. Mas sempre inovador. A poesia de Itamar não se resume a letras ou vinhetas, mas a uma atitude de ruptura. [...] (RUIZ apud ASSUMPÇÃO: 2006, p.57)
\end{abstract}

Por isso a poesia de Itamar pode ser abordada de diversas maneiras. Sobretudo porque essa "atitude de ruptura", sobre a qual Ruiz fala, está igualmente presente, em diversos momentos, nos outros parâmetros da composição e da performance. Isso nos impede de tentar isolar a poesia do restante ${ }^{155}$ por muito tempo (mesmo com fins de tentar analisa-la), pois em muitos casos ela incrementa sua própria sonoridade quando associada a outros sons que não sejam só os da voz; ou então, tem suas significações ampliadas ou modificadas através da maneira como é cantada, e do enredo que se delineia no contexto de um show ${ }^{156}$. Há dezenas de poemas escritos por Itamar, e cujas análises apontariam para diferentes aspectos de significação dada, inclusive, a variedade de procedimentos ocorrente também

\footnotetext{
155 Isso não é novidade na canção, essa simbiose entre letra e música. Ressaltamos que no caso de Itamar há mais questões intrincadas: sua própria figura, a performance ao vivo, o arranjo. Torna-se difícil isola-las, mesmo que para fins de análise.

${ }_{156}$ Um exemplo dessa última situação pode ser a canção de Jards Macalé, Costura, já citada no primeiro capítulo. Itamar a cantava em seus shows a partir de 1999. Nas apresentações que fez após ser operado de câncer, a costura do alfaiate passou a ser a costura da operação. Não que ele o tenha dito, a analogia (ou a metáfora) surge naturalmente pela situação da performance. O público subentende (ou constrói) esse sentido, e as significações da letra se alteram.
} 
no trato com o texto ${ }^{157}$ (e não só nas composições e arranjos). Poderiam ser elencadas matrizes poéticas.

Em seu estudo sobre a música da Vanguarda Paulista, a respeito do texto verbal e sonoro, Estrela Ruiz Leminski, analisa entre outras questões, a poesia de seus principais compositores, demonstrando alguns dos recursos poéticos utilizados (LEMINSKI: 2011, p.75). Em comum estaria, por exemplo, como importante aspecto, a metalinguagem, onde a música fala sobre a música. E obviamente em Itamar também ${ }^{158}$. Baseando-se em categorias propostas por Ezra Pound (melopeia, fanopeia, e logopeia ${ }^{159}$ ) Leminski aponta e analisa as diversas soluções poéticas encontradas pelos principais compositores da vanguarda, e dentre eles Itamar. Originalmente voltadas somente para a poesia, essas categorias podem perfeitamente ser aplicadas à canção, como observa Leminski (op.cit.: 2011, p.33). Fica claro também que quase sempre essas categorias estão presentes simultaneamente. Resgatemos algumas das observações feitas por Leminski, para que possam ser associadas mais diretamente a aspectos musicais. A própria autora coloca a questão, que poderia parecer óbvia por si, mas que possui um por que:

\begin{abstract}
A música e a poesia aparecem ligadas por grandes laços de afinidade entre si, que vivem do som, da articulação, da expressão, e podem ser ligadas pela transgressão. Ambas já transgrediram seus próprios limites, e nem mesmo os atributos que as definem as limitam, vide a poesia visual e a música de John Cage. (LEMINSKI: 2011, p.31)
\end{abstract}

Nas letras de Itamar, Leminski observa justamente a exploração do som (portanto da melopeia), através da aliteração como um dos recursos recorrentemente utilizado (além de onomatopeias ${ }^{160}$, paronomásias ${ }^{161}$ e da

\footnotetext{
157 Há letras que são quase prosa, como se fossem crônica, ou texto teatral, para ser encenado.

${ }^{158}$ Itamar fala não só sobre a música, mas sobre ofício de ser compositor e artista (em canções como Leonor; Vida de artista; Tetê tentei; Quem descobriu, descobriu; Cultura lira paulistana; Onda sertaneja; Quem canta seus males espanta; Sexto sentido; entre outras).

${ }^{159}$ Estas seriam categorias para auxiliar a identificação dos elementos básicos que constituem um poema escrito em versos. Esses elementos relacionar-se-iam respectivamente ao som, à imagem e ao pensamento, identificando que tipo de matéria sonora, matéria imagética e matéria intelectual um poema pode conter. (ref. Leminski, 2011, p.33)

${ }_{160}$ Criação de palavras a partir da imitação de um som. Observação dessa característica presente na poesia de Itamar feita também por Regina Machado (MACHADO: 2011, p.94-95).
} 
própria rima). Fonemas que se repetem sendo inclusive reforçados e destacados pela maneira de Itamar pronunciá-los ao cantar palavras, tal como na canção Tristes trópicos, em parceria com Ricardo Guará. Nesta canção esse parece ser o aspecto que mais prevalece ${ }^{162}$ :

O trópico tropica,

Emaranhado num trambique

A treta frutifica

E tritura todo o pique

A trapaça trina e troa

E extrapola cada dique

$O$ tratado é intrincado

Destratado é truque chique

O grito atravancado

Tranca até que petrifique

Tristes gregos e troianos

Desbragado piquenique
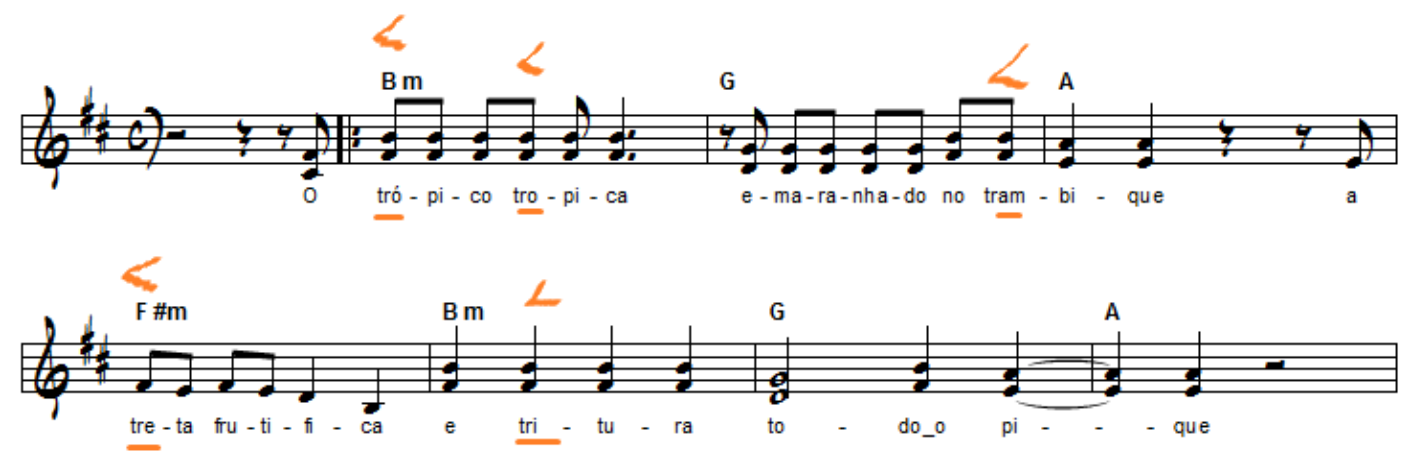

Fig. 46: Tristes trópicos - recurso de aliteração. (CD anexo faixa 33)

Podemos identificar, com mais clareza através da partitura (fig.46) como a repetição de um fonema com o mesmo tipo de consoante, através de sua

\footnotetext{
${ }^{161}$ Palavras com som semelhante, mas com sentido diferente, colocados juntas no texto pela proximidade sonora.

162 Itamar parece sempre buscar o som das palavras, mas sem sacrificar o sentido, sem provocar a associação forçada de ideias.
} 
inserção em diferentes palavras, propicia o surgimento de um ritmo paralelo àquele que é expresso pela melodia. É claro que os outros fonemas restantes também são responsáveis por definir a alturas das notas. Mas a reincidência chama a atenção para o elemento que está sendo repetido. $O$ (tr) ocorre em diferentes palavras e em momentos que não são regulares. As consoantes desse fonema provocam uma acentuação natural (enfatizada também pela interpretação) e nos fazem ouvir um ritmo suposto. Assim poderíamos identificar também sons com (c), através dos fonemas (co), (ca), (que); e igualmente ouvir o ritmo que surge na incidência de fonemas com a vogal (i). Teríamos também uma sobreposição de frases rítmicas uma vez que os timbres gerados pelas articulações dos fonemas provocam nuances sobre as notas cantadas. Esses ritmos supostos, por sua vez ressaltam também fragmentos melódicos.

Outra característica presente na poesia de Itamar, observada por Alice Ruiz (RUIZ apud ASSUMPÇÃO: 2006, p.61) e reforçada por Estrela Leminski (LEMINSKI: 2011, p.76) está em seu gosto por lista de coisas. Desde nomes de pessoas (nas canções Orquídeas, Justo você Berenice); cidades (nas canções Pesquisa de mercado II, Outras capitais, Ai que vontade); objetos (nas canções Leonor, Sonhei que viajava com você, Abobrinhas não e Vê se me esquece - em parceria com Alice Ruiz); até listas de ações tal como na canção Porque não pensei nisso antes ${ }^{163}$, em que descreve atitudes que poderiam ter sido tomadas para seduzir a amada. Há também uma "lista" de línguas em que se expressa. A canção Coração absurdo, é cantada na língua portuguesa e também em alemão simultaneamente. Itamar a canta em português e a cantora Suzana Salles em alemão, enquanto os vocais das Orquídeas do Brasil (nas vozes de Miriam Maria, Tata Fernandes e Nina Blauth) são cantados em inglês. Há outra canção Ich liebe dich, em que também adota trecho em alemão. Tanto nesta como em Coração absurdo, tira proveito da vasta presença de

\footnotetext{
163 A frase do filósofo René Descartes "Je pense, donc je suis" (penso logo sou), ou "Penso logo existo", conforme se diz vulgarmente, é também um mote que aparece em algumas canções, contudo transformada. Na gravação da canção Porque que eu não pensei nisso antes, Itamar a fala antes de cantar. Penso logo sinto, é o nome de outra canção, do CD Bicho de sete cabeças. E há ainda a música Sem pensar nem pensar, no CD com o mesmo título das parcerias póstumas com Sergio Molina.
} 
consoantes que a língua possui para explorar o ritmo. A canção In the morning também é cantada em inglês. Em Sonhei que viajava como você, termina com uma frase em japonês, e em Chavão abre porta grande, há um trecho em italiano.

A descrição desses objetos, ações, pessoas e lugares tendem a gerar imagens (fanopeia). Não seria somente a visualização de imagens literais, que o ouvinte pode imaginar enquanto escuta o que está sendo descrito, como na devolução dos objetos como os da letra de Alice Ruiz para canção em parceria com Itamar, Vê se me esquece (fig.47): "ultraleve", "carteira de saúde", "receita de quibe", "papel de seda", "meia bege", "bugue". Ela própria, como letrista, adotou para essa canção esse traço de Itamar de fazer listas.

Segundo Ruiz, Itamar sugeriu acrescentar ainda "do diabo que te carregue, te carregue, te carregue do diabo que te carregue" (na terceira e quarta linhas do poema). Isso incrementou o caráter irônico uma vez que, apesar da virulência de significado (que segundo Ruiz não the era própria naquele momento em que escreveu o poema) a frase é utilizada para imprimir uma mudança rítmica, pois não oferece pausa como vinha ocorrendo anteriormente para marcar essa espécie de ladainha. Fica demonstrado naquele instante que o personagem se exaltou, pois do ponto de vista de uma mensagem escrita, como a dessa carta, não haveria motivo para uma palavra ser repetida tantas vezes.

O simples fato de se listar objetos tende a criar uma imagem poética capaz de sugerir e descrever quais são as características das pessoas, dos tipos de ação e dos lugares que estão implicadas na situação. Como nesta canção, por exemplo, em que se tornam presentes um pouco da personalidade de duas pessoas que estão se separando, conforme expressa a letra a seguir, e onde é possível imaginar as situações em que viveram juntas. Através da seleção de coisas que elege para serem nominadas, na descrição dos objetos, o reclamante nos demonstra a maneira como passou a ver sua ex-companhia: 
Já que você não aparece venho por meio desta devolver teu

faroeste o teu papel de seda a tua meia bege tome também teu bugue leve teu

ultra-leve carteira de saúde tua receita de quibe de quiabo de quibebe do diabo

que te carregue te carregue te carregue do diabo que te carregue teu truque sujo

teu hálito teu flerte tua prancha de surfe tua idéia sem verve

que nada disso me serve já que você

não merece devolva minhas preces meu canto meu amor meu tempo por favor e minha

alegria que naquele dia só te emprestei por uns dias

E é tudo o que me pertence P.S. já que você foi embora porque não desaparece
e é tudo o que me pertence P.S já que você foi embora porque não desaparece

Fig. 47: Vê se me esquece, letra da canção. (CD anexo faixa 34)

Trata-se de uma carta. Nela há o pedido (quase uma intimação) de que se leve embora uma série de objetos, e também do que se supõe terem sido algumas atitudes incorretas da (o) parceira (o), como se essas ações fossem também coisas. O reclamante, por sua vez, quer de volta toda alegria e felicidade que acredita terem sido levadas, como se pudesse obtê-las novamente e tivessem características materiais. Não se sabe bem se houve de fato uma separação, pois a carta se inicia: "já que você não aparece [...]". Então se supõe que a pessoa a quem se dirigem as palavras simplesmente desapareceu sem dar explicações. O contrassenso (e ironia) está no fato de que essa alegria ("emprestada" por uns dias) e felicidade seriam frutos da relação, e se houve alguma ruptura (mesmo que unilateral) não há mais como recuperá-las. Ninguém seria capaz de carregar o sentimento que pertence ao outro consigo. O efeito musical resultante, obtido com a junção da letra de Ruiz com a música chega a ser maçante, este criado por Itamar: 


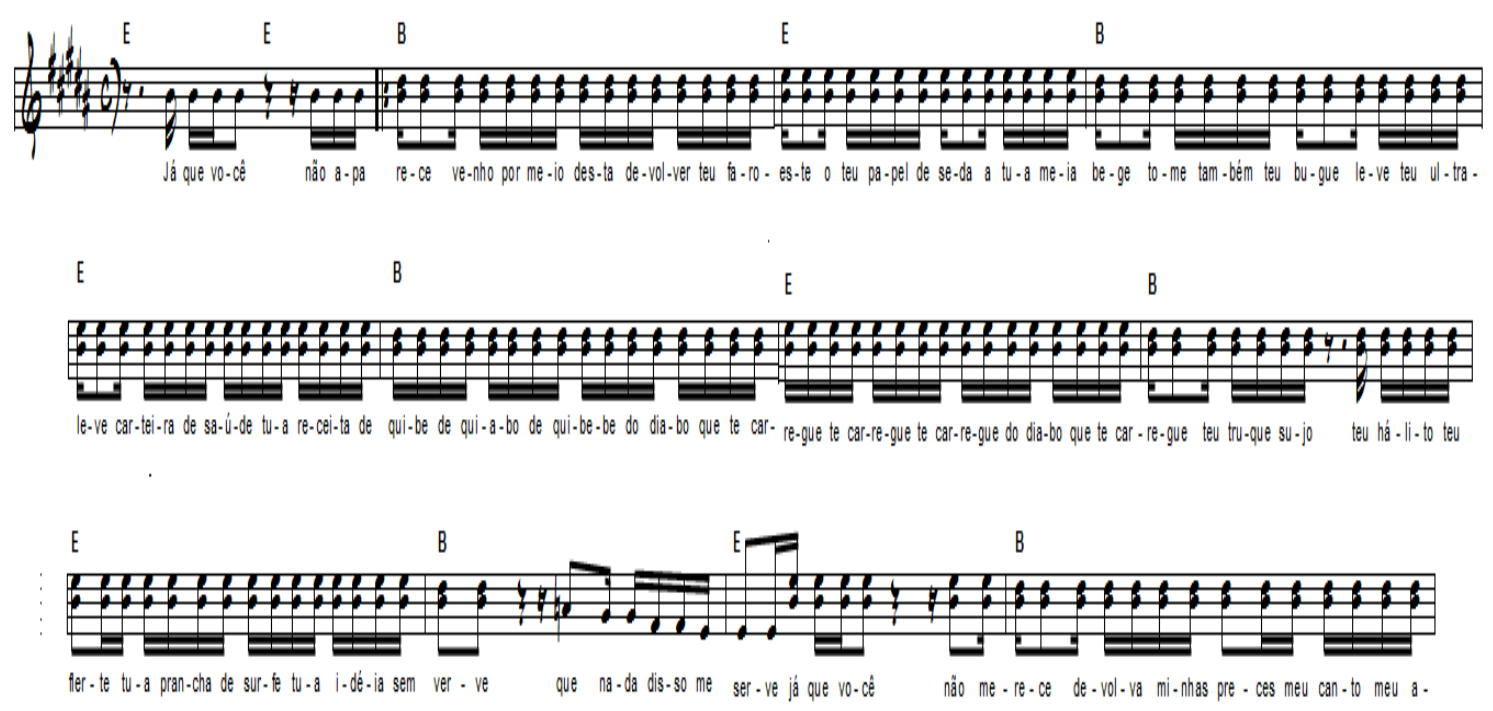

Fig. 48: Vê se me esquece, melodia repetitiva. (CD anexo faixa 34)

A melodia é repetitiva (fig.48), nas alturas e no ritmo, sugerindo o tom ${ }^{164}$ das pessoas que reclamam, monocórdicas, com um pouco de irritação, mas sem muita exaltação. A não ser pela expressão "do diabo que te carregue, te carregue, te carregue, do diabo que te carregue", onde o personagem se exaspera mas ele consegue conter-se em seguida e prossegue. Assim que 0 discurso se encerra, com uma melodia resolutiva (que seria o ponto final da carta), a ladainha recomeça, como reincidência do pensamento de alguém que está com algum incômodo ou problema, que não o consegue tirar da cabeça, e o reconta indefinidamente, num ciclo fechado. O único movimento de altura da melodia ocorre na abertura de voz, em que a mais aguda alterna entre ré sustenido e mi, e a mais grave permanece sobre a mesma nota si. Ainda assim esse pequeno salto alternado não desfaz a sensação de repetitividade propositalmente criada.

Quanto à "matéria intelectual do poema", conforme descreve Leminski, que "é o elemento que se revela na sintaxe do texto, na lógica de sua organização, em sua carga semântica, nas referências e influências artísticas e culturais que contém" (Leminski, 2011, p.33), baseando-se nas categorias de

\footnotetext{
164 Tom não no sentido musical, mas no sentido da inflexão da voz, da maneira de se expressar.
} 
Ezra Pound, também faria sentido aplicá-la no estudo da canção, e assim teríamos a logopeia. Aliando essa categoria aos conceitos definidos por Luiz Tatit ${ }^{165}$ para tratar do estudo da canção, podemos vislumbrar um pouco dessa intrincada simbiose entre letra e música.

\title{
Noite torta
}

\author{
Na sala numa fruteia \\ A naturesa está morta

Fig. 49: Noite torta, letra da canção. (CD anexo faixa 35)

\footnotetext{
${ }^{165}$ Resumidamente seriam: 1) Figurativização (Tatit: 1995, p.20-21), que identifica na melodia da categoria Canção características próximas à entoação da fala; e que por esse motivo cria um "sentimento de verdade enunciativa" para o ouvinte. 2) Passionalização (p.22-23) , uso de "continuidade melódica", como a presença de prolongamento melódicos e amplas oscilações de tessitura, expressando tensões temáticas de significado do texto; e 3) Tematização (p.2324), "segmentação de ataques consonantais", gerando motivos rítmicos e melódicos propícios à "construção de personagens", "valores-objeto" e "valores universais", à descrição de ambientes e situações.
} 
Essa letra (fig.49) é um notável exemplo de construção poética. Possui as três categorias de Ezra Pound, e os três conceitos de Luiz Tatit criados para estudar a canção.

Interpretada por Tetê Espíndola, e pelas Orquídeas do Brasil e o próprio Itamar, essa canção se inicia sem introdução, ou seja, sem preparação. A melodia já se apresenta a partir da segunda semicolcheia de som. Isso permite o contato imediato com ouvinte, ligando-o diretamente às palavras e à voz que as canta. Há no arranjo a presença de percussões (wood blocks, cowbell e afoxé, tocados por Nina Blauth) que ajudam a criar a ambiência do lugar da casa onde ocorre a cena. Quem fala é uma mulher que está em pé, pensando alto e falando sozinha. Está na cozinha, e os wood blocks lembram o tic-tac e o movimento do ponteiro do relógio que normalmente ecoam sob o silêncio, quando não há mais outros sons predominando. Eles dramatizam a sensação de solidão. A poesia é rica em imagens: "está pingando o chuveiro, que banho mais apressado" é seguido por "molhado caíste fora no espelho minha alma chora". A sintaxe vai sendo completada aos poucos. O chuveiro está pingando, porque já foi desligado, e lhe sobraram gotas residuais. O companheiro foi embora e o sons dos pingos ainda perduram. Supostamente tomou banho às pressas e mal se enxugou, pois queria sair logo de lá. O som dos pingos a lembram de que ele se foi e de que "caiu fora", que a deixou naquele estado, paralisado. As gotas que caem são também suas próprias lágrimas. É no espelho em que ela pode ver além, e perceber a natureza de sua tristeza que é profunda e provém de sua alma. "Lá fora está tão gelado". Ele foi para outro lugar e ela ficou. O frio lá de fora é o que ela sente ali, e é também a frieza dele.

As estrofes possuem a mesma métrica. Mas a última estrofe contém rimas seguidas, provocando aliteração, e nos chamando a atenção para o peso que aquela mulher sente pelos reveses da vida naquele momento. Acredita que dela não possui usufruto. Acha que a vida é tal como a roupa suja no tanque, acúmulo de trabalho e esforço que talvez não possam ser enfrentados. Mas o dilema está no fato de que se não os enfrentar, porque não tem forças, talvez permaneçam acumulados para sempre. O conteúdo dessa letra seria semelhante ao da canção Vê se me esquece não fosse a oposição diametral 
entre dramaticidade e ironia que cada uma das canções carrega, respectivamente. Nesta letra não há o ar de brincadeira e nem de prosa (obtido no texto Alice Ruiz). Aqui ocorre uma grande síntese de imagens que tentam descrever a densidade da percepção e do sentimento dessa mulher.

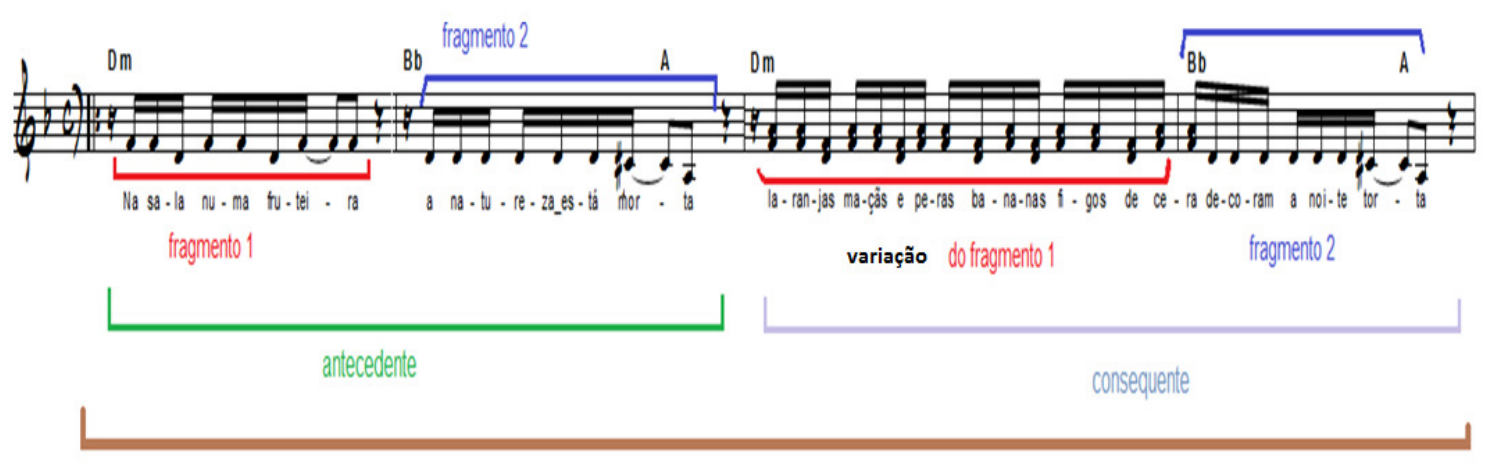

10 periodo

Fig. 50: Noite torta, trecho da melodia. (CD anexo faixa 35)

Podemos associar o tipo de construção melódica desta canção ao que Tatit chama de tematização. São criados motivos rítmico-melódicos, repetidos nos trechos da cada estrofe. Todas as estrofes obedecem à mesma métrica, e a melodia mantém características semelhantes (fig.50). Musicalmente elas são trabalhadas como pergunta e resposta ou, como denomina Arnold Schoenberg ${ }^{166}$, como um período formado respectivamente por antecedente e consequente. "Na sala numa a fruteira, a natureza esta morta" é a primeira frase musical composta por dois fragmentos melódicos (na fig.50, fragmentos 1 e 2, compassos 1 e 2). A resposta musical acompanha a outra frase de texto, "laranjas maçãs e peras, bananas figos de cera, decoram a noite torta", variando o fragmento 1 e concluindo com o fragmento 2 (compassos 3 e 4). Essa recorrência motívica (há a repetição de notas e de ritmo), conforme aponta Tatit, é a condição propícia e eficiente que se observa, na canção em geral (não só na musica de Itamar), para ocorrer a construção dos personagens, para a descrição de estados de ser e de ambientes, como é o

${ }^{166}$ No livro Fundamentos da composição musical (SCHOENBERG: 1996, p.50 a 55) 
caso de Noite torta. São quatro estrofes. Na segunda e na quarta estofes temos a transposição da melodia para um tom acima, fato que conjumina com momentos onde a personagem se expõe mais ao descrever a agruras de sua condição, que vem à tona.

Teríamos ainda a figurativização, que são as características que aproximam a construção melódica dos traços entoativos da fala. Elas se dariam aqui através das terminações descendentes sempre presentes (vide ainda na fig. 50 os fragmentos 2). Na segunda e quarta estrofes, onde parece se concentrar a densidade emocional da personagem, tem-se a impressão de ocorreram inflexões ascendentes. No entanto esse efeito se dá porque é o momento onde ocorre a elevação da melodia para um tom acima (fig.51, compasso 1). Ao invés de alternar as duas notas (ré e fá) como ocorria no antecedente do primeiro período, essa melodia transposta (do segundo período) se mantém na nota sol, acentuando o efeito de tensão discursiva e melódico-harmônica. Vale sugerir que, devido a esses fatores, possivelmente essa transposição da melodia acresça ao efeito de passionalização (que é o terceiro termo cunhado por Tatit que utilizamos aqui para auxiliar a reflexão), mesmo que de maneira contida.

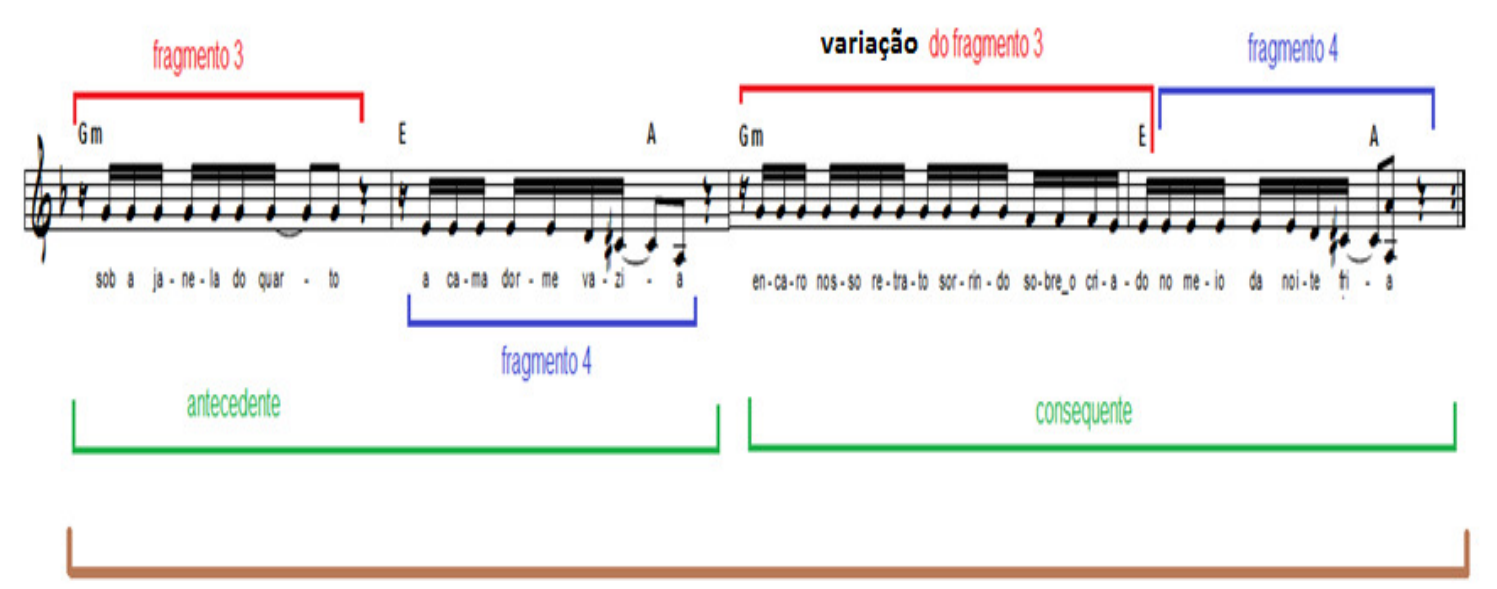

\section{$2^{2}$ periodo}

Fig. 51: Noite torta, organização da construção melódica do segundo período da canção. (CD anexo faixa 35$)$ 
A exploração das vogais, com vocalizes prolongando-as, seria uma maneira de conectar o ouvinte às tensões e significados presentes no texto. Embora as características da melodia não permitam que as vogais sejam estendidas, Tetê Espídola o faz ao cantar, através da exploração de timbres. Ao invés de estender a duração, entoa as vogais trabalhando diferentes tipos de emissão. Ainda assim, ocorrem alguns prolongamentos de vogais quando possível, aliando-os à "brincadeira" com o timbre. Sua interpretação, optando por utilizar esses recursos, traz um elemento novo, que complexifica a dramaticidade do texto, na medida em que traz algo de jocoso à personagem (que parece rir tristemente de sua situação). Ao final aí sim, realiza um improviso com vocalize, sem utilizar as palavras, enquanto todos cantam, transformando a primeira frase "na sala numa fruteira, a natureza está morta" em refrão.

\subsection{Desdobramentos da música de Itamar Assumpção}

Desdobramento poderia ser tudo aquilo que um material, musical no caso, pode desencadear ou gerar, além do controle de quem o criou. É a repercussão de algo. Chamamos de "desdobramentos da música de Itamar Assumpção" duas situações. Primeiro as produções artísticas que decorreram de parcerias, e que foram completadas após seu falecimento. Trabalhos onde não participou da finalização, mas em que forneceu o material poético-musical inicial para ser acabado. Como ocorreu com o disco em parceria com o percussionista Naná Vasconcelos (Isso vai dar repercussão), onde parte dos arranjos foi finalizada postumamente. Os dois discos (Pretobrás I/ e Pretobrás III) foram produzidos dos por dois músicos e produtores, Beto Villares e Paulinho Lepetit, a partir de gravações de voz e violão, e seriam também desdobramentos. Eles complementam a segunda trilogia idealizada por Itamar (a primeira foi Bicho de sete cabeças) e por isso concretizam uma intenção expressa por ele. O último disco gravado por Itamar, em que participou de todo o processo foi, Pretobrás I. Há ainda o disco Sem pensar nem pensar, com uma série de letras de Itamar musicadas pelo compositor Sergio Molina, e com indicação feita pelo próprio Itamar de que as canções fossem interpretadas 
pela cantora Miriam Maria e de que fossem gravadas num disco. Destacamos esse trabalho dentre outras parcerias ${ }^{167}$ por que ele foi pensado por Itamar como um projeto. As outras parcerias foram feitas com diferentes compositores afins, mas inseridas em seus próprios discos e shows, não sendo oriundas de uma proposta específica. Exceção feita à série de canções inéditas com Alice Ruiz, que deveriam ter se tornado um ou dois discos, mas cujo único registro em fita cassete que existia se extraviou.

Em segundo, chamo de desdobramento, o disco com as canções de Ataúlfo Alves. Embora Itamar não seja o autor das músicas consegue estabelecer seu ponto de vista, que é contundente e forte, através dos arranjos e de sua interpretação. Ao mesmo tempo, as canções são preservadas, e Ataúlfo se mantem tão presente quanto Itamar. Nessas gravações podemos enxergar com bastante clareza o quanto a sonoridade de suas próprias composições está impregnada de aspectos de arranjo, e o quanto uma canção pode ser transformada. Itamar se impõe como presença de forma serena, sem resvalar em Ataúlfo e sem diminui-lo ou exaltá-lo em sua majestade. Um exemplo dessa abordagem de Itamar está no arranjo de Laranja madura, citado no item 5 das matrizes de composição (Baixo e fala ritmada: quem é quem?).

\section{Estranha ideia}

O poema de Itamar chamado Estranha ideia ${ }^{168}$, musicado por Sergio Molina resgata algumas importantes questões que sempre permearam a obra de Itamar. Primeiro a preocupação em realizar algo que fosse novidade em termos artísticos. Feito que, sem dúvida, já havia alcançado através de toda a variedade de elementos que concatenou na obra, para estabelecer seu estilo de letra, composição, arranjo e performance. No entanto a possibilidade de trabalhar também com uma complexidade harmônica não foi contemplada. A noção de que esse item poderia ser incorporado na criação artística de maneira musical foi percebido por Itamar quando sua obra resvalou na de Arrigo Barnabé. Ou seja, o fato de que poderia haver a complexização dos elementos

\footnotetext{
${ }^{167}$ Com Alice Ruiz, Ná Ozzetti, Dante Ozzetti, Alzira Espíndola, Luiz Tatit, entre outros.

${ }^{168}$ Canção do disco Sem pensar nem pensar, de Sergio Molina e Miriam Maria, 2009.
} 
melódicos e harmônicos sem que isso representasse o afastamento do papel canção $^{169}$ de comunicar, sensibilizar e transformar. Porém era uma seara que não fazia parte de sua formação autônoma e que talvez não fosse de seu interesse desenvolver, mesmo que tardiamente. Ao entregar as letras a Sergio Molina deixou claro, segundo o próprio Molina, de que não queria que as composições fossem uma imitação de seu estilo, mas que pudessem conter as "estranhezas" diversas com as quais sabia que a música desse outro autor trabalhava (sobre tudo em relação à harmonia).

Outra questão relaciona-se ao "feminino". Várias das letras utilizam-se do "eu lírico" feminino, ou se não diretamente, contemplando a questão da relação homem-mulher. Por isso foram designadas diretamente a uma cantora, Miriam Maria, que havia feito parte das Orquídeas do Brasil (banda que o acompanhou nos anos da década de 90). Aliada a essa questão, levando em conta que Itamar estava seriamente adoecido, pudemos perceber que de algum modo ele parecia ainda mais descomprometido com a necessidade de que sua criação tivesse o formato de "produto artístico", qualquer que fosse esse produto, apesar de ter partido dele a ideia do projeto. Sabemos que escrevia muito nesse período de doença. Alguns de seus poemas para esse projeto $^{170}$ são quase prosa, tal como já havia ocorrido em outros momentos de sua produção artística. Observam-se nos textos dessa série diversas assimetrias que tiveram que ser trabalhadas pelo compositor Molina para dar vez à prosódia e especialmente nesta canção, Estranha ideia (fig.52):

\footnotetext{
${ }^{169}$ A respeito da função que a canção pode desempenhar social, cultural e historicamente, trata-se de uma discussão extensa e polêmica que não se pretende levantar aqui. Os três "papeis" da canção levantados aqui advém do pensamento que o próprio Itamar acaba deixando implícitos em suas colocações (em entrevistas, nas conversas informais e nas letras das canções).

${ }_{170}$ Ditou todas as letras pelo telefone, para mim e para Sergio Molina, sempre perguntando quantos poemas já havia passado e se a quantidade era suficiente para completar a gravação do disco.
} 

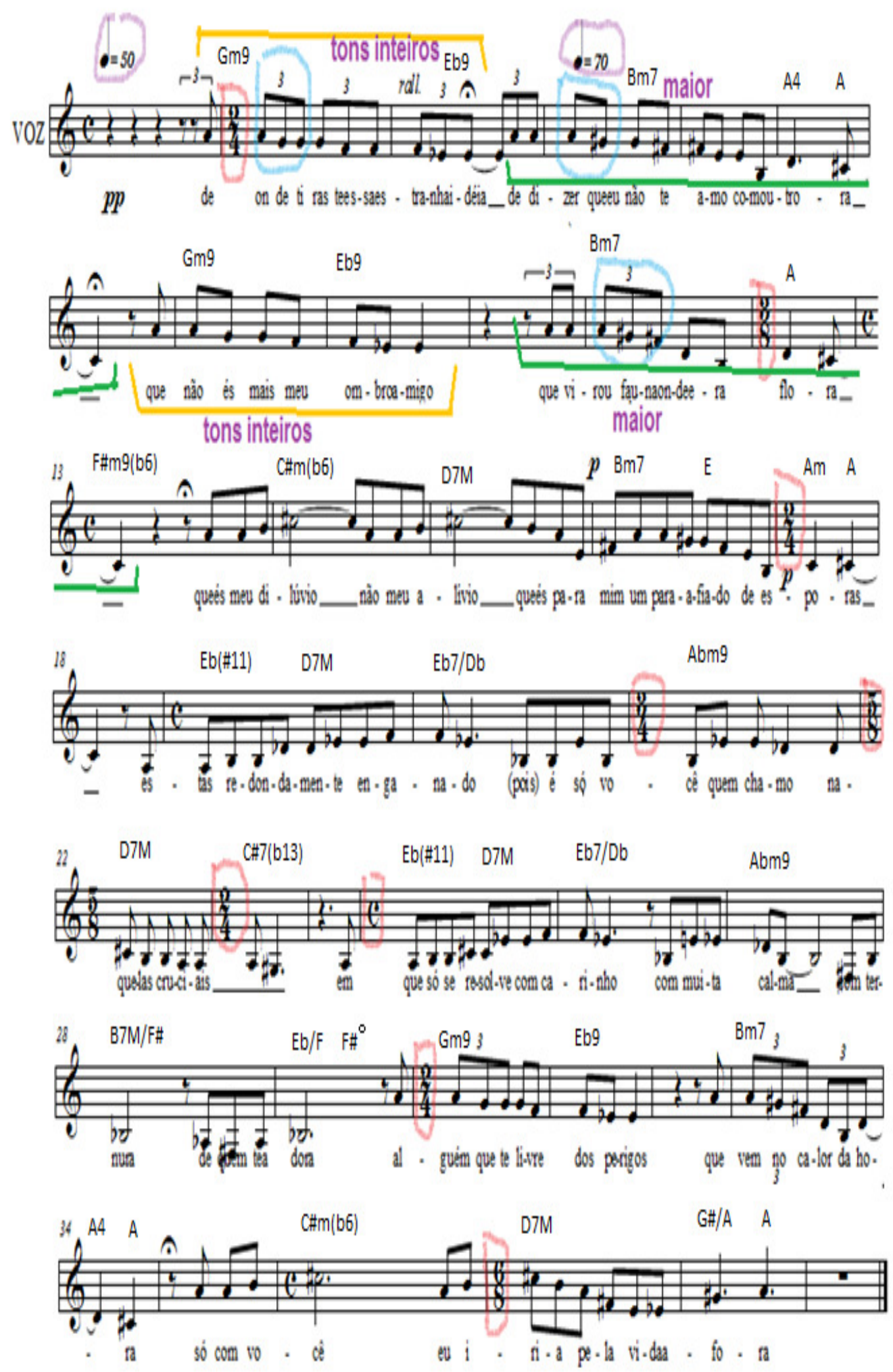

Fig. 52: Estranha ideia, poema de Itamar musicado por Sergio Molina. Presença de compassos assimétricos para respeitar a prosódia. (CD anexo faixa 36 ) 
A solução encontrada por Molina, ao invés de enquadrar o poema em um mesmo tipo de compasso fixo, foi tentar priorizar o fluxo da "fala", da prosódia, compondo a melodia observando as respirações que seriam ocorrentes no texto dito. Como decorrência, os agrupamentos de pulsos (ou seja, os compassos), foram sendo alterados na medida em que permitissem da inteligibilidade das palavras. Foi inserida também a alternância entre subdivisões binárias e ternárias dos tempos dos compassos (compassos 2 e 4; 28), como possibilidade a mais de combinações que permitissem a manutenção de um canto flexível. A sustentação dessa flexibilidade se dá, da mesma forma, com as oscilações propositais de andamento. Segundo Molina $^{171}$, houve ainda a intenção de refletir musicalmente o que era expresso pelo poema, onde o suposto "estranhamento" ao qual se refere fica estabelecido pela utilização da escala de tons inteiros na melodia ao mesmo tempo em que é amenizado e por uma harmonização tonal ${ }^{172}$. O poema, cantado em primeira pessoa, tenta dissuadir a ideia de estranhamento que the foi imputada através do discurso que profere, e a música também, através da harmonia. Portanto haveria, paralelamente, uma referência aos procedimentos da música do século XX e sua inserção no âmbito da canção.

Certamente a solução musical dada por Itamar, se fosse realizada, seria bastante diferente, tanto melódica como ritmicamente. Molina trabalha com a alternância entre escalas de tons inteiros e maiores (com os modos jônico e lídio) nos compassos 2, 3 e nos compassos 4, 5, respectivamente. A partir do compasso 18 inverte o sentido da melodia de tons inteiros, que passa a ser ascendente. Já Itamar possivelmente (se adotarmos as referências observadas até então encontradas nas composições) solucionaria a questão das assimetrias de letra com o aceleramento da velocidade do texto para compactá-lo num espaço menor. Quanto às melodias, as construiria baseadas em tríades, muito provavelmente mantendo uma mesma tonalidade, adotando

\footnotetext{
${ }^{171}$ Através de declaração informal durante a gravação do CD Sem pensar nem pensar, em 2009 , da qual participei.

${ }^{172}$ Utilizando o campo harmônico expandido de Lá maior.
} 
repetições de notas, mesmo em se tratando de uma canção lenta sem o apelo rítmico, com pouco ou quase nenhuma utilização de notas escalares.

É interessante observar que a possibilidade de desdobramento e de performatividade estão sempre presentes na obra de Itamar. Mesmo que os resultados sejam, tais como este, tão distintos quanto aqueles que ele próprio obteria se estivesse evolvido em todo o processo de composição. Este traço poderia ser considerado como mais uma peculiaridade de sua obra. O material poético e musical que Itamar produz parece ser propício a ser apropriado e reelaborado, tal como ele próprio o fez com as informações musicais que agregou. Apesar da aparente complexidade na construção musical da canção exemplificada ${ }^{173}$ (fig.52), o resultado soa objetivo porque Itamar possui clareza ao se expressar. E uma vez que Molina tenha repeitado essas características, como o fez, a audição "leiga" não necessariamente rejeita os acontecimentos musicais por não "compreendê-los" e pode até nem se dar conta, propriamente, de que exista essa complexidade. Sobre o ofício de compor há um poema esclarecedor de Itamar, letra Variações (CD anexo faixa 37) do CD Pretobrás III:

$$
\begin{aligned}
& \text { Quem quer fazer boa música } \\
& \text { Tem que ter jeito pra coisa } \\
& \text { Não vende em supermercado } \\
& \text { E nem no mercado das pulgas }
\end{aligned}
$$

Quem quer fazer boa música

Tanto faz uma ou uma dúzia

Precisa estar preparado

Para enfrentar semifusas

Quem quer fazer boa música

Tem que bolar uma fuga

Contar compasso quebrado

Cantar à bocca chiusa

\footnotetext{
${ }^{173}$ Procedimentos semelhantes de composição podem ser identificados nas canções Esquisito, Entendeu Nereu?, e Infinitos sons, todas parcerias entre Itamar e Sergio Molina.
} 
Quem quer fazer boa música

Sabe a importância da pausa

Traído ou bem amado

Tem que forjar ferro gusa

Quem quer fazer boa música

Tem que entender quando cruza

Tem que ter muito cuidado

Tentar cigarra e saúva

Quem quer fazer boa música

Tem que ter cruz inclusa

Tem que ser médico e louco

Tem que aprender fazer curva

Quem quer fazer boa música

Tem que encarar a medusa

Tem que passar o recado

Tem que saber o que é hipotenusa

Quem quer fazer boa música

Tem que pisar ovos e uvas

Tem que obrigar o diabo

Sair debaixo de chuva

Quem quer fazer boa música

No coração vai ter dúvida

Tem que ter muito escutado

Às vezes viver de brisa

Quem quer fazer boa música

Dispensa coisa confusa 
Além de tocar dobrado

Tem que ter um a ou mais musas

\section{Trilogia Pretobrás}

O CD em parceria com Naná Vasconcelos possui apenas 7 canções, e foi lançado postumamente. Itamar já estava doente quando se efetuaram as gravações, tendo passado pela primeira das seis cirurgias as quais foi submetido em decorrência de um câncer no intestino. Por desentendimentos a respeito de como a produção desse trabalho seria finalizada acabou abandonando o projeto, que foi resgatado pelo músico e compositor Paulo Lepetit e encampado pela família de Itamar após sua morte. O material era muito rico, segundo ambos, e já estava praticamente finalizado. Lepetit optou por dar acabamento às gravações rearranjando (uma vez que já havia sido convidado por Itamar para fazê-lo) e inserindo outros instrumentos além das percussões e das vozes de Naná Vasconcelos (que havia efetuado as gravações em conjunto com Itamar). Já em relação às gravações de Pretobrás II (estas finalizadas por Beto Villares) e III o procedimento foi diferente. Só existiam gravações de voz e violão espalhadas em diversos estúdios ${ }^{174}$. Essas gravações foram reunidas e selecionadas para constituírem a finalização da trilogia Pretobrás, conforme era intenção do próprio Itamar. Como em muitos casos presentes na música popular brasileira o violão constitui uma fonte inequívoca de informação musical agregada à canção. Vários compositores apresentam suas composições cantando com o acompanhamento do instrumento. E no caso de Itamar, tocando acordes ou linhas de baixo. Essa questão era absolutamente clara para Paulinho Lepetit (conforme explica em entrevista anexa). Lepetit extraiu, da maneira de tocar violão que Itamar possuía, informações suficientes para desenvolver as ideias de arranjo. Nas gravações, diversas vezes deixa aparente somente a condução do violão retirando os outros instrumentos, para evidenciar essa questão.

Um exemplo é a canção Devia ser proibido (CD anexo faixa 38 ), composta por Itamar para o amigo Paulo Leminski, nesta gravação contando

${ }_{174}$ De Luiz Waack, Simone Sou e Alfredo Bello, Sandra Peres e Paulo Tatit, Paulo Le Petit. 
com a participações de Zélia Duncan, Marcos da Costa, Jean Trad, Luis Chagas, Paulo Lepetit e, evidentemente, o próprio Itamar cantando e tocando violão. Percebe-se como a condução do violão estabelece uma pulsação ao mesmo tempo relaxada, (estabelecendo um andamento que não perturba o canto), e precisa ritmicamente. Apenas com acordes o violão apresenta uma linha de baixo e uma divisão rítmica nas cordas agudas que os completam. Ao mesmo tempo Itamar utiliza a movimentação de oscilação da mão direita (que se desloca em semicolcheias) para percutir as cordas, emitindo diferentes timbres (ora abafando as cordas impedindo a audição das alturas, ora obtendo sons metálicos). Trata-se de importantes informações musicais, uma vez que com elas consegue estabelecer uma sonoridade para viger. Através do apoio desse baixo que advém do violão ( e que não é exatamente uma linha de baixo e sim uma insinuação) podem ser constituídos os espaços em que Itamar quer ouvir o silêncio. Tornam-se evidente os diversos pulsares sobre os quais os músicos constituem suas "levadas", conduções e frases, conversando ou reforçando essa expressão inicial de voz e violão. E, segundo Lepetit, podendo gerar um arranjo com menos sobreposição de informações, fato que destaca como sendo favorável uma vez que, em sua visão, ocorria excesso nos arranjos em várias faixas dos diversos discos anteriores gravados em estúdio. Esse excedente de informação musical devia-se, conclui, às diversas possibilidades tecnológicas que se apresentavam, desde a possibilidade de multiplicação dos canais de gravação até a quantidade de tempo de gravação permitida pelas mídias. Itamar queria utilizar todos os canais que estivessem disponíveis bem como o máximo de tempo de gravação que fosse possível registrar.

No caso do CD Pretrobrás II, o produtor Beto Villares (com quem Itamar já havia expressado a vontade de trabalhar - situação que não foi possível criar em vida) também baseia a direção musical em vestígios deixados por Itamar. Na canção Agora é que são elas (CD anexo faixa 39) a "levada" de bateria é cantada com a voz, antecipadamente por Itamar, no início da gravação. Em diversas canções desse disco o violão é deixado em descoberto, casando as informações timbrísticas que emite com sons sintetizados ou trabalhados com efeitos. De onde se pode concluir que, em ambas as produções, a maneira 
com que os dois músicos conseguiram obter soluções musicais foi através da escuta. Ouviram a fonte e a expandiram. No primeiro caso, de Paulinho Lepetit buscando frases que pudessem estar insinuadas (contando também com a larga experiência que possuía, de convivência com Itamar - e portanto, com condições de decodificar as informações). E no segundo caso, de Beto Villares, encontrando uma atmosfera sonora e timbrística compatível. O resultado dos dois trabalhos é bem distinto e pode ser entendido como desdobramento na medida em que não seguem uma diretriz condicionada. Mais um indício de que é pelo meio da escuta, ou seja, através do tempo presente e da presença de quem a realiza que a obra de Itamar se efetiva. 


\section{CONSIDERAÇÕES FINAIS}

Itamar Assumpção teve uma formação musical fora dos meios acadêmicos, tal como a maioria da produção artística da música popular. Não se esperaria que fosse de outra forma, dadas às condições pelas quais ele veio a se aproximar da música. Essa observação apenas amplifica a questão dos processos criativos. Itamar fez uma série de sínteses, por conta própria, aproximando-se de situações que respondessem a seus anseios pessoais. Tinha obsessão pelo novo, por ser criativo e por romper (de alguma maneira e a qualquer custo) com linguagens estabelecidas, e também por ser popular e fazer jus à linhagem da música popular urbana brasileira. Era orgulhoso por ter recebido elogios de Hermeto Pascoal e Elis Regina, considerados por críticos e público com dois grandes músicos da história da música popular urbana brasileira do século XX. Acabou por conseguir definir um estilo próprio apoiado na escuta e na reelaboração dos materiais musicais que estavam à sua mão. Apesar de praticamente não ter o hábito de ler literatura ou poesia aprimorou seus próprios poemas destinados à canção de uma maneira sofisticada.

Apoiando-se em processos espontâneos, de exercício de observação e intencionalidade, em teatralidade e performatividade, Itamar constituiu uma obra que não era somente cabível nos invólucros dos discos e das partituras. No entanto ela não deixou de existir, mesmo com a ausência de sua presencialidade $^{175}$, porque o grau de performatividade perdura nos registros sonoros dos CDs dos vídeos e na poesia. Itamar influenciou, com seus processos criativos, dezenas de músicos que tiveram oportunidade de trabalhar com ele. Em contrapartida soube ouvir a expressão que tinham para ofertar, fato que agregou a sua obra. Fazer música é um processo coletivo, com quaisquer que sejam as implicações disso, e mesmo que em caso extremo expresse uma relação que parta do indivíduo para ele mesmo (ainda assim aquele que se expressa será diferente daquele que ouve e o sentido se completa através desse ciclo). Aqueles que de algum modo estiveram ligados a

\footnotetext{
${ }^{175}$ Segundo reflexões de Paul Zumthor, constatando a forte implicação que há na presença do corpo, em relação ao potencial de "comunicação poética" da performance (ZUMTHOR: 2000, p.39-41).
} 
Itamar, fazem parte de uma mesma "família" sonora, sentem-se participantes e cúmplices de um acontecimento histórico - tal como aquela primeira conversa que tive com ele, em que parecia que algo de extrema importância seria dito. $\mathrm{E}$ de fato o foi, na forma de um recado amplo e perene.

Constituiu um estilo diretamente ligado à pratica, ao fazer musical, um arcabouço de conhecimento que contribui para que os diversos caminhos que a música brasileira tem tomado possam prosseguir. A obra de Itamar é um ramo dessa frondosa e secular árvore em que se constitui a música brasileira. Dentre as ferramentas utilizadas nesta pesquisa serviram de apoio as abordagem de diversos autores, que permitiram que fossem acessados e visualizados os frutos mais altos. No entanto, como bom "dedo verde" que cultivava orquídeas e todo o tipo de plantas, o próprio Itamar forneceu as pistas, através das inúmeras conversas que pudemos ter e dos anos de convívio musical. "Sou do mato", diz ele na canção Ir para Berlin, "sou bicho, não tenho medo de cobra, muito menos de ouriço". O próprio Itamar sabia quais eram os frutos mais maduros e os indicou para que pudéssemos usufruir. 


\section{BIBLIOGRAFIA}

ARTAUD, Antonin. O teatro e seu duplo. São Paulo: Max Limonad, 1984.

ANTOKOLETZ, E. The Music of Béla Bartok: A Study of Tonality and Progression in Twentieth-Century Music. Berkley, Los Angeles, and London: University of California Press, 1984.

ASSUMPÇÃO, Itamar, 1949-2003. Pretobrás: Porque Que Eu Não Pensei Nisso antes? Vols. 1 e 2. Transcrições: Clara Bastos. São Paulo: Ediouro, 2006.

BERENDT, Joachin: O Jazz do Rag ao Rock. São Paulo: Editora Perspectiva, 1990.

CALADO, C. Tropicália: a história de uma revolução musical. São Paulo: Editora 34, 1997. . Jazz ao Vivo. São Paulo: Editora Perspectiva, 1989.

CASTRO, Ruy. Chega de Saudade: a História e as Histórias da Bossa Nova. São Paulo, Companhia das Letras, 1990.

CAYMMI, Stella. Dorival Caymmi, O mar e o Tempo. São Paulo, Editora 34, 2001.

CHION, Michel. Musicas, Media e Tecnologias. Lisboa: Instituto Piaget, 1997.

COLEÇÃO: A Historia do Samba. 34 Fascículos e CDs. Rio de Janeiro, Editora Globo, 1997.

COOK, N, A guide to musical Analysis. London: Norton, 1992.

ELIADE, Mircea. Aspectos do Mito. Lisboa: Edições 70, 1986.

FAVARETTO, Celso: Tropicália Alegoria Alegria. Cotia: Ateliê Editorial, 2000.

FERRAZ, S. Música e Repetição: a diferença na música contemporânea. São Paulo: EDUC,1998.

FIGUEIREDO, Janaína P. Amado Batista e FERREIRA, Marieta de Moraes, organização. Usos e Abusos da História Oral. São Paulo: FGV Editora, 2006.

FRANCIS, André. Jazz. São Paulo: Martins Fontes, 1987.

GARCIA, Walter. Bim Bom: a Contradição sem Conflitos de João Gilberto. São Paulo, Paz e Terra, 1999.

GIORGIO, Fabio Henriques. Na Boca do Bode - entidades musicais em trânsito. Londrina: Prefeitura do Município de Londrina, Secretaria Municipal de Cultura PROMIC, Sercomtel. ISBN 85-98015-07-5, 2005. 
GREINER, Christine. O corpo - pistas para estudos indisciplinares. São Paulo: Annablume, 2005.

HIDALGO, Luciana. Arthur Bispo do Rosário - o senhor do labirinto. Rio de Janeiro, 1996: Editora Rocco Ltda.

IAZZETA, Fernando. Música e Mediação Tecnológica. São Paulo: Editora Perspectiva, 2009.

JORDÃO, Gisele; ALLUCCI, Renata R.; MOLINA, Sergio; TERAHATA, Adriana Miritello (organizadores). A Música na Escola. ISBN: 978-85-61020-01-9 Allucci \& Associados Comunicações; 3D3 Comunicação e Cultura; Ministério da Cultura: São Paulo, 2012.

KERN, Berry. The New Grove Dictionary of Jazz. London:The Mac Millan Press Limited, 1994.

KOSTKA, Stefan. Materials and Techniques of Twentieth-Century Music.NJ, EUA: Pearson Education, Inc.,2006.

MACHADO, Regina. A voz na Canção Popular Brasileira - um estudo sobre a vanguarda paulista. Cotia, SP: Ateliê Editorial, 2011.

MONK, Meredith et al. Art as spiritual practise. PAJ: a journal of performance ans art, NY; Cambrige, 72 (Vol 2, Nr 3), pp 18-34, Sept. 2002.

MURGEL, Ana Carolina Arrruda Toledo. Alice Ruiz, Alzira Espíndola, Tetê Espíndola e Na Ozzetti: Produção Musical Feminina na Vanguarda Paulista, 2005.

NESTROVSKY, Arthur. Música Popular Brasileira Hoje. Publifolha, São Paulo 2002.

OLIVEIRA, laerte Fernandes de. Em um Porão de São Paulo - o Lira Paulistana e a produção alternativa, 2002. São Paulo: Annablume Editora Comunicação.

PALUMBO, Patrícia. Vozes do Brasil, vol. 1. São Paulo: Dórea Books and Art, 2002.

SCHAFER, R. Murray. A Afinação do Mundo, 1997. São Paulo: Editora Unesp. . O Ouvido Pensante,1992. São Paulo: Editora Unesp.

SCHOENBERG, Arnold. Fundamentos da Composição Musical. São Paulo: EDUSP, 1996.

SANDRONI, Carlos. Feitiço Decente. Rio de Janeiro: Jorge Zahar Ed., 2000.

SEKEFF, Maria de Lourdes. Da Música - seus usos e recursos. $2^{\mathrm{a}}$ edição. São Paulo: Editora Unesp, 2007. 
SEVERIANO, Jairo. Uma história da Música Popular Brasileiro - das Origens à Modernidade. São Paulo: Ed. 34, 2008.

SEVERIANO, Jairo e MELLO, Zuza Homem de. A Canção no Tempo: 85 anos de Músicas Brasileiras (vol. 1 e 2). $3^{\mathrm{a}}$ ed. São Paulo: Editora 34, 1998.

STRAUS, Joseph. Introduction to post-tonal theory. Englewood Cliffs, NJ: Prentice Hall, 1990

TATIT, Luiz. O Cancionista, Composição de Canções no Brasil, São Paulo, Edusp, 1996 . O Século da Canção. Cotia, Ateliê Editorial, 2004

TINHORÃO, José Ramos. As Origens da Canção Urbana. Editorial Caminho, Lisboa, 1997. Pequena História da Música Popular: da Modinha à Lambada. $6^{\text {a }}$ ed. São Paulo, Art, 1991.

TUREK, Ralph. The elements of music - Concepts and application. Volume two. McGraw-Hill, 1996.

ULHÔA e OCHOA, Martha e Ana Maria, organizadoras. Música Popular na América latina - pontos de escuta. Porto Alegre: Editora da UFRGS, 2005.

VALENTE, Heloísa de Araújo Duarte. Os Cantos da Voz - entre o ruído e o silêncio. São Paulo: Annablume, 1999.

abordagens sobre a canção. São Paulo: Via Lettera, 2007.

VELOSO, Caetano. Verdade Tropical. São Paulo, Companhia das Letras, 1997.

VIANNA, Hermano. O Mistério do Samba. Rio de Janeiro: Jorge Zahar e Editora UFRJ, 1999.

ZUBEN, Paulo. Ouvir o Som: aspectos da organzação da música do século XX. - Cotia, SP: Ateliê Editorial, 2005.

ZUMTHOR, Paul. Escritura e Nomadimo. Cotia, SP: Ateliê Editorial, 2005. Performance, Recepção, Leitura. São Paulo: Educ, 2000. 


\section{DISCOGRAFIA}

ASSUMPÇÃO, Itamar. Caixa Preta. São Paulo: Selo SESC SP, 2010. 12 CDs. Contém toda a discografia, além de Pretobrás II - Maldito Vírgula, 2010; Pretobrás III - Devia ser proibido, 2010.

ASSUMPÇÃO, Itamar; VASCONCELOS, Naná. Isso vai dar repercussão. São Paulo: Elo Music, 2004. 1CD.

ASSUMPÇÃO, Itamar. Pretobrás - Porque que eu não pensei nisso antes...São Paulo: Atração Fonográfica, 1998. 1CD.

Pra sempre agora: Ataulfo Alves por Itamar Assumpção. São Paulo: Paradoxx Music, 1995. 1 CD.

LPs [ 1994. 2 CDs.] . Bicho de 7 cabeças. São Paulo: Baratos Afins, 1993. 3 Paulo: Continental, 1988. 1 LP. Intercontinental! Quem diria! Era só o que faltava!!! São Sampa Midnight - Isso não vai ficar assim. São Paulo: Mifune Produções, 1985. 1 LP. Às próprias custas S/A. São Paulo: Lira Paulistana, 1982. 1 LP.

Paulistana, 1981. $1 \mathrm{LP}$.

Beleléu leléu eu. São Paulo. São Paulo: Lira

BARNABÉ, Arrigo. Clara Crocodilo. São Paulo: Thanx God Records, 1995. $1 C D$.

God Records, 2006. 1CD.

Missa in memoriam Itamar Assumpção. São Paulo: Thanx

\section{DISSERTAÇÕES, TESES, REVISTAS, ARTIGOS.}

FALBO, Conrado Vito Rodrigues, Beleléu e Pretobrás: palavra, performance e personagens nas canções de Itamar Assumpção, dissertação de mestrado Universidade Federal de Pernambuco, Centro de Artes e Comunicação, Programa de Pós graduação em Letras, Recife, 2009.

JAMBERG, Renata O Contrabaixo na Musica Popular Atonal: Um estudo a partir das composições seriais do álbum Clara Crocodilo de Arrigo Barnabé. Monografia, bacharelado em música. Faculdade Santa Marcelina, em São Paulo, 2010.

LEMINSKI, Estrela Ruiz. Ouvidos Atentos: O texto verbal e sonoro na música da Vanguarda Paulista da década de 1980, dissertação de mestrado. Universidade Federal do Paraná no programa de Pós-Graduação em Música. Curitiba, 2011. 
Revista Arte em Revista, $n^{\circ}$ 8, São Paulo: CEAC (Centro de Estudos Contemporâneos), 1984.

Revista Qualis, edição 23, novembro de 1994, São Paulo, Qualis Editora.

STOROLLI, Wânia Mara Agostini. Movimento, Respiração e Canto: A performance do corpo na criação musical. Tese de doutorado, ECA/USP, 2009. - Performatividade da voz e processos de

criação. Artigo apresentado no XXI Congresso da Associação Nacional de Pesquisa e Pós-Graduação em Música - Uberlândia - 2011.

\section{VÍDEOS}

Itamar Assumpção, gravação de show ao vivo no teatro do Instituto Itaú Cultural, 2002.

Daquele Instante em Diante, documentário dirigido por Rogério Veloso, produzido pelo Instituto Cultural Itaú, na série Iconoclássicos, São Paulo, 2011.

No repique do tambú - o batuque de umbigada Paulista. São Paulo: Associação Cultural Cachuêra, TV Cultura e Rede SESC - SENAC, 2003. 1DVD.

Programa Ensaio TV Cultura, Itamar Assumpção, show gravado ao vivo, 1999.

Programa Provocações TV Cultura, Itamar Assumpção, entrevista a Antônio Abujamra, 2000. 


\section{ANEXOS}

Anexo 1: Índice alfabético das canções presentes na discografia.

Abobrinhas não

Pretobrás I

Aculturado Isso vai dar repercussão

Adeus pantanal Intercontinental

Agora é que são elas Pretobrás II

Ai de mim Sem pensar nem pensar

Ai, que saudades da Amélia_ Ataulfo Alves por Itamar Assumpção pra sempre agora Ai que vontade Bicho de 7 cabeças vo.III Amanticida Às próprias custas S.A.

Amigo Arrigo Pretobrás I

Andei pensando Sem pensar nem pensar

Anteontem, melô da U.T.I. Pretobrás III

Apaixonite aguda Pretobrás I

Aranha Beleléu, leléu, eu

Assim Naná ensina Isso vai dar repercussão

Atire a primeira pedra Ataulfo Alves por Itamar Assumpção pra sempre agora Ausência Intercontinental Autorização Sem pensar nem pensar Baby Beleléu, leléu, eu Batuque Às próprias custas S.A. Beijo na boca Beleléu, leléu, eu

Bicho de 7 cabeças Bicho de 7 cabeças vo.III Bom crioulo Ataulfo Alves por Itamar Assumpção pra sempre agora Pretobrás II 
Cabelo duro Isso vai dar repercussão

Cadê Inês Sampa midnight

Caiu a ficha Sem pensar nem pensar

Chavão abre porta grande Sampa midnight

Ciúme doentio Pretobrás III

Ciúme do perfume Bicho de 7 cabeças vol.II

Coração absurdo Bicho de 7 cabeças vol.II

Cultura Lira Paulistana Pretobrás I

Custa nada sonhar Bicho de 7 cabeças vol.I

Denúncia dos Santos Silva Beleléu Às próprias custas S.A.

Deus te preteje Pretobrás I

Desapareça Eunice Sampa midnight

Devaneio Pretobrás III

Devia ser proibido Pretobrás III

Dor elegante Pretobrás I

E o quico Sampa midnight

Embalos Beleléu, leléu, eu

Enquanto uns ficam falando Pretobrás III Entendeu Nereu? Sem pensar nem pensar

Espírito que canta Intercontinental Esquisito Sem pensar nem pensar

É tanta água Bicho de 7 cabeças vol.II

Ei você aí Bicho de 7 cabeças vo.III Eldorado Sampa midnight Elza Soares Pretobrás II 
Errei sim Ataulfo Alves por Itamar Assumpção pra sempre agora

Errei erramos Ataulfo Alves por Itamar Assumpção pra sempre agora

Estranha ideia Sem pensar nem pensar

Estropício Bicho de 7 cabeças vol.III

É tanta água Bicho de 7 cabeças vol.II

Eu tenho medo Pretobrás III Extraordinário Pretobrás I

Fico louco Às próprias custas S.A.

Filho de Santa Maria Intercontinental

Fim de festa Isso vai dar repercussão

Fon fin fan fin fun Beleléu, leléu, eu Fundamental Pretobrás III Gente bem também samba Ataulfo Alves por Itamar Assumpção pra sempre agora Grude Pretobrás III Homem-mulher Intercontinental Ich lieb dich Pretobrás I Ideia fixa Sampa midnight Infinitos sons Sem pensar nem pensar In the morning Bicho de 7 cabeças vol.II Ir pra Berlim Pretobrás II Isso não vai ficar assim Sampa midnight Já que tem que Pretobrás I Je t'ame mais que o Jerome Pretobrás II 
Jubileu Ataulfo Alves por Itamar Assumpção pra sempre agora

Justo você Berenice Isso vai dar repercussão

Lambuzada de dendê Bicho de 7 cabeças vol.III

Laranja madura Ataulfo Alves por Itamar Assumpção pra sempre agora Leonor Isso vai dar repercussão

Leva meu samba Ataulfo Alves por Itamar Assumpção pra sempre agora Logo que eu acordo Bicho de 7 cabeças vol.I

Longe de mim Pretobrás II Luzia Beleléu, leléu, eu

Maldito vírgula Pretobrás II Mal menor Intercontinental Maremoto Intercontinental

Más línguas Pretobrás II Me basta Bicho de 7 cabeças vol.II

Meus tempos de criança Ataulfo Alves por Itamar Assumpção pra sempre agora Milágrimas Bicho de 7 cabeças vol.II Movido a água Sampa midnight

Mulata assanhada Ataulfo Alves por Itamar Assumpção pra sempre agora

Na cadência do samba Ataulfo Alves por Itamar Assumpção pra sempre agora Na próxima encarnação Isso vai dar repercussão

Não importa(prelúdio) Sem pensar nem pensar

Não importa Sem pensar nem pensar

Não há saídas Intercontinental

Não vou ficar Às próprias custas S.A. Sampa midnight 
Nem que chova canivete Ataulfo Alves por Itamar Assumpção pra sempre agora

Nem James Brown Sem pensar nem pensar

Nega música Beleléu, leléu, eu

Negra melodia Às próprias custas S.A. Nego dito Beleléu, leléu, eu Ninguém me canta como você Pretobrás III Nobody knows Bicho de 7 cabeças vol.II

Noite de terror Às próprias custas S.A.

Noite torta Bicho de 7 cabeças vol.I O bonde São Januário Ataulfo Alves por Itamar Assumpção pra sempre agora Oferenda Intercontinental Oh! Maldição Às próprias custas S.A.

O homem e o cão Ataulfo Alves por Itamar Assumpção pra sempre agora Olho no olho Pretobrás I Onda sertaneja Bicho de 7 cabeças vo.III Orquídeas Bicho de 7 cabeças vol.I

Os incomodados que se mudem Pretobrás III O tempo todo Pretobrás II Ouça-me Intercontinental Outras capitais Pretobrás I Parece que bebe Bicho de 7 cabeças vo.III Parece que foi ontem Intercontinental Peço perdão Às próprias custas S.A.

Penso logo sinto Bicho de 7 cabeças vol.II Penso logo sinto Sem pensar nem pensar 
Pesadelo Pretobrás I

Persigo São Paulo Pretobrás III

Pesquisa de mercado I, II e III Intercontinental

Pirex Pretobrás III

Pois é Ataulfo Alves por Itamar Assumpção pra sempre agora Poltinglen Pretobrás I

Porque que eu não pensei nisso antes Pretobrás I

Pretobrás Pretobrás I

Procurei Pretobrás II

Prezadíssimos ouvintes Sampa midnight

Prezadíssimos ouvintes Sem pensar nem pensar

Que barato Às próprias custas S.A.

Queiram ou não queiram Pretobrás I

Quem canta seus males espanta Bicho de 7 cabeças vo.III

Quem descobriu, descobriu Bicho de 7 cabeças vol.I

Quem é cover de quem Bicho de 7 cabeças vol.I

Que tal o impossível Pretobrás III

Requebro da mulata Ataulfo Alves por Itamar Assumpção pra sempre agora Reengenharia Pretobrás I

Samba enredo Pretobrás II Sampa midnight Sampa midnight Santo de casa Bicho de 7 cabeças vo.III

Se a obra é a soma das penas Bicho de 7 cabeças vol.I Se eu fiz tudo Beleléu, leléu, eu 
Sei que é covardia Ataulfo Alves por Itamar Assumpção pra sempre agora

Sem pensar nem pensar I Sem pensar nem pensar

Sem pensar nem pensar II Sem pensar nem pensar

Sexto sentido Intercontinental

Sons infinitos Sem pensar nem pensar

Sonhei que viajava com você Bicho de 7 cabeças vol.II

Sujeito a chuvas e trovoadas Bicho de 7 cabeças vol.I

Sutil Intercontinental

Tetê tentei Sampa midnight

Tristes trópicos Bicho de 7 cabeças vol.II

Todo esse tempo I Pretobrás II

Todo esse tempo II Pretobrás II

Totalmente à revelia Sampa midnight

Tristes trópicos Bicho de 7 cabeças vol.II

Tua boca Bicho de 7 cabeças vo.III

Vá cuidar de seu vida Pretobrás I

Vai, mas vai mesmo Ataulfo Alves por Itamar Assumpção pra sempre agora

Vamos nessa Sampa midnight

Variações Pretobrás III

Vassalo do samba Ataulfo Alves por Itamar Assumpção pra sempre agora

Vê se me esquece Bicho de 7 cabeças vol.III

Venha até São Paulo Bicho de 7 cabeças vol.I

Vida de artista Pretobrás I

Vide verso meu endereço Às próprias custas S.A. Pretobrás III 
Você está sumindo Às próprias custas S.A.

Vou de vai-vai Pretobrás I

Vou tirar você do dicionário Bicho de 7 cabeças vol.I

$Z$ da questão meu amor Sampa midnight

Zé Pelintra Intercontinental 


\section{Anexo 2: ENTREVISTAS}

\section{a) Conversa com ALICE RUIZ}

Clara Bastos: Sim. Foi interessante falar com o Arrigo e com o Paulo Barnabé, porque eles estavam presentes...

Alice Ruiz: Naquele momento inicial...

CB: No processo em que ele estava fazendo a síntese dele, o Itamar. Isso é interessante, porque parece é mágica. Em música popular, pelo menos, é um trabalho coletivo. Claro, ele fez a síntese e seguiu. Mas tem a questão da convivência, de algumas coisas que eles viveram lá, que são interessantes. Neste trabalho o foco principal não é a poesia do Itamar, mas não há como deixar de falar sobre ela.

Alice Ruiz: Claro, porque ele era um grande letrista também. Você está gravando já?

CB: Pode gravar?

Alice Ruiz: Eu não sei o que eu vou dizer agora, porque...

CB: Não, não se incomode com a...

Alice Ruiz: Eu falei um pouco, desse aspecto dele, no songbook.

CB: Isso eu cheguei a ler. Eu li todos.

Alice Ruiz: Aliás, tem o Luiz (Chagas) também.

CB: Tem o Luiz, tem vários depoimentos. Tem algumas pessoas que falaram mais sobre a pessoa do Itamar e têm outras que falaram sobre a música. Eu penso que isso é a coisa principal, a obra mesmo. Então, como você vê a maneira dele escrever?

Alice Ruiz: O que me chamou atenção, primeiro, no Itamar foi a música mais do que a letra. Mas daí eu comecei a prestar mais atenção e ver o quanto ele tinha incorporado, pelo menos, nos dois primeiros disco a coisa do teatro. São personagens que ele cria, ele conta histórias a partir de personagens, isso nos dois primeiros.

CB: Ele encarna esse personagem. Porque ele mesmo vai cantar, então muitas vezes ele encarna, ele sabe que ele vai cantar, ele faz um papel, ele escreve um papel para ele, de certo jeito.

Alice Ruiz: Eu acho que sim.

CB: Talvez, não sei. Eu estou... 
Alice Ruiz: Não sei se é só ele. Mas, sei lá, é uma interpretação tua. Mas acho que sim, acho que sim. Principalmente com o Beleléu, o Nego Dito. Nego Dito, Beleléu. Que era um personagem dele mesmo. Mas mais do que isso, mulheres que ele botava: "Deixa de conversa mole, Luzia". Ele criava essas personagens femininas para discutir com elas questões, outras. A Luzia, ele discute futebol, se eu não me engano.

CB: É.

Alice Ruiz: E a Berenice, ele discute a música. Não, daí a Tetê...

CB: Tetê ou...

Alice Ruiz: É uma conversa sobre... Olha que bonitinha essa ideia dele, olha a genialidade de letrista. Ele faz uma letra sobre dizendo que ele não conseguiu fazer o que ela pediu, (risos) mas ele faz. Dizendo que não conseguiu, ele faz. Eu acho que isso continua coisa teatral, eu acho, de ele criar situações inusitadas. $\mathrm{E}$ mesmo escolhas diversas que ele tinha nas letras eram meio inusitadas, eram umas coisas que você não esperava. Aquela Que Tal o Impossível. As coisas que ele pensa em fazer para conquistar não são as coisas tradicionais que se pensa em fazer para conquistar.

CB: Do Petrobrás, você diz? Aquele: "Tentei seduzir você domesticando elefantes...”. Não, não é isso que você está pensando, não é?

Alice Ruiz: Não. Não, mas essa sim, essa sim. Como é o nome dessa música? Esqueci.

CB: Eu também esqueci ${ }^{176}$.

Alice Ruiz: Esqueci agora. Eu estava pensando nessa na verdade, mas o Que Tal o Impossível também é uma proposta... Lembra?

CB: Sim.

Alice Ruiz: Também é uma proposta de coisas impossíveis. E nisso eu acho que consistiu originalidade dele. Não só nisso.

CB: É a coisa que você também falou, chegou primeiro a música, mas a letra... você e o Paulo Leminski trabalhavam com isso, não é?

Alice Ruiz: Não, mas chegou primeiro nesses dois primeiros. O Sampa Midnight, para mim, foi um divisor de águas. Acho que no Sampa Midnight ele se assume mais como letrista mesmo.

CB: Aí já não é mais a coisa tão teatral. Ele volta a atenção dele para a poesia?

${ }^{176}$ A canção é Porque que eu não pensei nisso antes do CD Pretobrás I. 
Alice Ruiz: Exatamente. E uma das características dele era a coisa das listas, ele adorava fazer listas.

CB: Listas de coisas, de lugares, de...

Alice Ruiz: De lugares, de coisas a fazer para seduzir, de coisas a levar... É a Leonor? Que ele faz uma lista das poucas coisas que ele tem, que são hilárias, tem um senso de humor, ele tinha um senso de humor, como letrista, muito grande, mas um humor sutil, não um humor, assim, ele não fazia... Não tinha nada a ver com aquela coisa, por exemplo, da Língua de Trapo que era só humor. Não, ele falava de coisas seriíssimas, mas com a leveza do humor.

CB: Fazendo songbook, e também tocando com ele, percebi recorrências de ideias, que ele sempre utilizava. Mas isso ocorre desde o começo, como se fossem vertentes, que depois ele vai trabalhando ao longo da obra. Então essas coisas de listar nomes...

Alice Ruiz: Nomes e coisas.

CB: Lugares.

Alice Ruiz: Nomes, coisas, lugares.

CB: De querer viajar.

Alice Ruiz: É, ele fez aquela das homenagens para as capitais. Tudo para desarmar na impossibilidade de viver em São Paulo (risos).

CB: Eu acho interessante um compositor que não tem formação musical, como o Itamar. Não que ele não tenha estudado. Ele estudou da maneira que ele tinha para estudar. Se você pegar um músico que faz uma escola normal, que se forma, é possível que, dependendo da instituição, não desenvolva a criatividade de uma maneira tão intensa. E no caso da poesia, como você vê isso? Uma pessoa que não é letrada, mas extremamente inteligente como o Itamar... Como é possível surgir uma pessoa assim?

Alice Ruiz: Eu acho que passa pelo mesmo critério de ter essa liberdade, essa independência dos cânones acadêmicos etc. Mas aí é que está a genialidade dele, aí é que você vê mais a genialidade mesmo. Porque, primeiro, era alguém que tinha o que dizer. Porque, assim, tem um monte de gente que sabe fazer poesia, mas não tem o que dizer. O Itamar tinha muito para dizer. Todas as coisas do Itamar, mesmo aquelas que parecem mais banais e mais corriqueiras, mais falando do cotidiano, elas estão carregadas de significados, carregadas de substância. E poesia tem muito a ver com o você ter o que dizer. $\mathrm{E}$ eu acredito que a forma poética, o que lhe dava, era a mesma coisa que lhe dava na música, essa proposta de ruptura, essa proposta de fazer algo diferente. Dar continuidade ao mesmo tipo de coisa que se vinha fazendo. Mas a novidade mesmo, trabalhar com o novo. Dizer de uma maneira nova coisas interessantes. $\mathrm{E}$ isso é poesia. Mesmo que ele não tenha estudado. 
CB: A poesia é, de fato, romper um pouco com as formalidades da língua, abrir. Isso seria uma característica. Então nesse sentido dá para dizer que ele é um poeta.

Alice Ruiz: Não, eu sempre disse, o nome do artigo no songbook é $O$ Grande Poeta Não.

Alice Ruiz: Porque ele dizia: "Eu sou poeta não." Aí eu briguei com ele, falei: "Não, você é um grande poeta."

CB: Ele fica bravo?

Alice Ruiz: Quando eu dizia que ele era poeta? Não, ele adorou. Adorou, imagina que ele ficou bravo. Itamar não ficava bravo comigo.

CB: Comigo também não, nunca reclamava. Era mais com os caras que...

Alice Ruiz: Eu vi o Itamar ficar muito bravo... Não, com mulheres também, ele ficava bravo com mulheres.

CB: Você está dizendo que, na verdade, ele tinha essa liberdade... E você acha que ele foi atentando para isso por conta dele também, ou também pelo contato que teve com você, com o Paulo?

Alice Ruiz: Ele disse que teve muito a ver com esse contato conosco.

CB: O Sampa Midnight é depois de vocês terem se conhecido?

Alice Ruiz: É. Quando a gente se conheceu só tinham os dois primeiros discos. Ele já tinha algumas músicas do Sampa Midnight, tanto que ele tocou lá quando a gente se conheceu, em 83, lá em Curitiba. Ele tocou algumas novas. Bom, ele saiu de Curitiba cheio de livro da gente. Não, cheio de livro não, na verdade só tinha publicado Navalha na Liga, que deu origem a nossa primeira parceria, e acho que o Paulo tinha publicado só o Não fosse isso era tanto, não fosse tanto era quase que é livro dos oitentas poemas, só. A gente tinha publicado esses dois. Daí, naquele ano mesmo eu lancei Paixão chama Paixão, eu levei para ele, trouxe para ele a primeira vez que eu vim para São Paulo. E aí ele já fez outra parceria também, daquele mesmo jeito, fazendo "colcha de retalhos", como ele fazia. Quer dizer, veja só como ele tinha o senso poético, porque, claro que, segundo ele, conduzido pela música. Mas essa coisa de fazer "colcha de retalhos" e pegar um poeminha daqui, um poeminha dali, um pedacinho de um outro poema dali, e fazer aquela montagem. As nossas duas primeiras parcerias foram assim.

CB: As parcerias foram assim? Interessante. O Arrigo escreveu uma missa para o Bispo do Rosário. Você sabe quem é ele, o Arthur Bispo do Rosário?

Alice Ruiz: Não. 
CB Eu até falei, que tinha tudo a ver com o Itamar, e ele concordou. Ele era um homem que havia pertencido à marinha, e que depois de alguns anos acabou indo parar num manicômio, onde permaneceu por cinquenta anos. Apesar de ser tido como um louco, desenvolveu trabalho de bordados em mantos e estandartes. Hoje em dia essa coleção é considerada obra de arte. O Arrigo apontou essa característica do trabalho do Itamar: "O Itamar trabalhava com uma estrutura musical muito simples, se você pensar em termos de harmonia e tal." Ele fazia daquilo um negócio muito refinado. Como alguém que pega uma coisa que vai ser descartada e revaloriza isso. Agora eu estou fazendo essa relação, já que você falou sobre essa colcha de retalhos. Ele sabe como juntar os materiais e transformar. Você vê um pouco assim?

Alice Ruiz: Melodicamente, ele não é tão rico.

CB: Ritmicamente é o forte dele.

Alice Ruiz: Porque apesar dele tocar todos os instrumentos, a coisa dele era 0 baixo, que é muito rítmico, que dá pulsação. $\mathrm{E}$ eu acho que ele partia, se você olhar as composições do Itamar cruas, muito mais da coisa rítmica do que de uma coisa melódica. Só que na hora de ele fazer o arranjo, na hora dele levar isso para o palco, ou levar isso para um CD, aí ele arrasava e fazia de cada pequena mudança uma...

CB: Um acontecimento.

Alice Ruiz: É.

CB: Mas eu digo em relação à poesia mesmo. Você o vê transformando, usando materiais simples também de letra e de... entende o que eu digo? $\mathrm{Na}$ música, ele usa poucas notas e transforma aquilo, reelabora de uma maneira que fica refinado. Com a poesia você o vê fazendo isso? Se bem que tem palavras que não são comuns, assim, ele usa palavras até palavras que não são muito usuais em poesias.

Alice Ruiz: Como, por exemplo?

CB: Agora, como eu vou me lembrar, não sei. Você o vê usando a palavra, a língua dessa maneira ou não?

Alice Ruiz: Não, eu acho que isso é mais uma leitura tua.

CB: Não é nem leitura, é uma pergunta mesmo.

Alice Ruiz: Mas não especialmente. Eu falei, ele falava de coisas corriqueiras de uma forma nova, de uma forma diferente. Não sei eu entendi o que você quer dizer. A questão é a seguinte, o Itamar podia não ter formações acadêmicas, mas, mais uma vez, não só o pensamento dele tinha substância, como era pensamento sofisticado.

CB: Sim. 
Alice Ruiz: E aí o que ele escrevia ficava sofisticado. Mesmo quando ele está falando de futebol, mesmo quando ele está falando de combustível de carro.

CB: Sim. É impressionante, fico impressionada com a inteligência assim. Não é nem com a inteligência...

Alice Ruiz: Mas eu não acho que ele se preocupava em usar palavras simples ou não, ele ia mais pelo som das coisas. Mesmo essas mulheres, tirando a Tetê, mas essas mulheres que, de repente, ele... Eleonor ou Luzia, se você olhar, elas conduzem para a rima.

CB: Sim.

Alice Ruiz: Ele escolhia nomes que proporcionasse...

CB: Uma diversidade de palavras para poderem ser rimadas.

Alice Ruiz: Exato. Agora, é engraçado porque eu estou fazendo um esforço muito grande para olhar para o Itamar letrista, já que em nossa parceria era eu quem dava a letra para ele, então...

CB: Não, de qualquer jeito...

Alice Ruiz: Eu estou me esforçando...

CB: Entendi, tudo bem.

Alice Ruiz: Tentando abstrair a forma como a gente se relacionava e tentando falar dos discos...

CB: Como se você não tivesse ali, mas daqui a pouco você fala sobre isso, você estando ali.

Alice Ruiz: Mas está difícil, está difícil.

CB: Não, mas tudo bem. A gente não consegue muito assim enxergar muitas vezes.

Alice Ruiz: Como se enxergar? Não, não...

CB: Eu digo, porque você olhar como uma pessoa que...

Alice Ruiz: Enxergá-lo.

CB: É, enxergá-lo. De qualquer forma, assim, mesmo ele tendo... você disse que foi bem impactante assim o contato com vocês...

Alice Ruiz: O contato conosco. 
CB: Mudou a maneira dele pensar.

Alice Ruiz: Sim.

CB: Mas mesmo assim ele sempre manteve a própria característica.

Alice Ruiz: Não...

CB: Sempre enxerga o Itamar.

Alice Ruiz: Mas isso faz parte da... é louco isso, é dialético, mas faz parte de você firmar uma ideia como letrista. Não é que ele tenha sido influenciado verbalmente por nós, eu acho que ele pode ter se sentido mais letrista. Ter olhado para o seu...

CB: Se valorizado.

Alice Ruiz: Se nós duas falarmos ao mesmo tempo, você não vai conseguir. Agora eu não lembro o que eu ia dizer.

CB: Desculpa, desculpa, eu te atrapalhei.

Alice Ruiz: Não, não, eu queria só completar o...

CB: Eu fico quietinha.

Alice Ruiz: A influência não se deu verbalmente, não se deu dele, assim, começar a fazer coisas parecidas conosco. Mas eu acho que foi mais no sentido de olhar para o que ele poderia produzir de mais poético. Pronto.

CB: Legal. Ele percebeu a própria força que ele tinha?

Alice Ruiz: Exatamente, exatamente. Daí, voltando a coisa do Grande Poeta Não, você disse dele ter brigado, pelo contrário, ele gostou porque eu acho que tem muito a ver com isso. Quando você entra em contato com o trabalho de uma pessoa, você tem conhecimento do que ela faz, conhecimento da arte, conhece como se processa a arte que aquela pessoa produz, e você mostra para ela os seus pontos mais fortes, não é que você esteja a influenciando. Mas você está, sei lá, ajudando a escolher caminhos, não é?

CB: Sim, sim.

Alice Ruiz: Então aqui foi mais por ali, e vice-versa.

CB: Claro.

Alice Ruiz: E vice-versa também. O Itamar, para mim, foi também... mas também, nós estamos falando dele, não é?

CB: É, mas isso também não impede, porque é uma via de duas mãos. 
Alice Ruiz: É.

CB: O Arrigo falou assim: "O Itamar foi essencial." Porque o som dele entrou com suingue, ele fez arranjos para o Arrigo, arranjo de base. Então o Arrigo tem uma coisa assim mais acadêmica mesmo. Ele é super musical.

Alice Ruiz: Não, mas eu entendo você.

CB: E aí a força, o Itamar veio com uma força e vice-versa. Essa questão de intercâmbio, de troca, na verdade é um motor.

Alice Ruiz: É claro que é. Eu acho que ali também aconteceu muito isso na relação dos dois, porque eles aparecerem praticamente simultaneamente.

CB: Sim.

Alice Ruiz: Os dois foram bem simultâneos. Mas eu, antes de conhecê-los, eu já tinha a minha escolha. Eu sempre gostei do trabalho do Arrigo, mas já me identifiquei mais com o Itamar por causa do suingue.

CB: Sim. É uma coisa orgânica, ele deixa a música orgânica, pulsando. E, evidentemente, o Itamar não ia falar assim: "Eu conheci Alice e o Paulo e agora eu vou fazer que nem eles." Ele não era burro. Porque tem gente que é literal.

Alice Ruiz: Não, não.

CB: A gente está mesmo só conjecturando porque são muito sutis esses pontos.

Alice Ruiz: Não seria o Itamar se fizesse isso.

CB: É claro!

Alice Ruiz: Como quando ele e o Arrigo se encontraram também. É a mesma coisa, se ele entrasse na onda do Arrigo, nós perderíamos um monte de maravilhas. E vice-versa.

CB: Não tinha como, não tinha como entrar. Ele entendeu o que o Arrigo fazia e por um tempo, ali, ele serviu e aquilo abriu a cabeça dele, aí...

Alice Ruiz: Mas a parceria tem essas características de troca de energias. Se você troca energia, se você está fraco e troca energia com uma pessoa forte, você pode até ficar mais forte, mas para outra pessoa não adiantou muita coisa. Quando são duas pessoas fortes fazendo a parceria fica duplamente forte.

CB: Potencializa. Claro, claro! 
Alice Ruiz: É. Principalmente quando há afinidades. Ali, no caso do Arrigo e do Itamar, a principal afinidade era de rupturas. Assim como Itamar comigo, que eu sempre trabalhei coma linguagem de uma forma... eu gosto de dizer 0 simples, porém, de formas novas, ou de dizer coisas que ainda não foram ditas. Mas de uma forma simples que todo mundo entenda. Esse jogo de dizer o simples de uma forma sofisticada ou rara, e vice-versa, de dizer o sofisticado de uma coisa de uma forma acessível, que todo mundo entenda, eu acho que foi o lugar onde a gente se encontrou, o Itamar e eu. Porque ele já tinha isso, só que isso ficou mais forte com a nossa relação. E eu já tinha isso, mas tive isso mais forte, musicalmente, com a nossa relação.

CB: Lógico, depois que você tem parcerias inúmeras de música com outras pessoas, mas isso também, possivelmente, influenciou a sua forma de escrever, independente de ser musicado, os poemas?

Alice Ruiz: Não, não.

CB: Isso não? Você pensa para a música ou você tem um tipo de...

Alice Ruiz: Tem alguns parceiros que botam música em poema mesmo, mas quando eu estou escrevendo, eu já sei se é letra ou se é poema, mas...

CB: A letra é poema também, não é?

Alice Ruiz: É, pelo menos para mim é, eu procuro ser poética nas letras, embora tenha muitas diferenças.

CB: Claro, claro.

Alice Ruiz: A poesia escrita é uma coisa.

CB: Contando só o som das palavras ou com o silêncio, é bem diferente você ter uma melodia que vai veicular aquela palavra.

Alice Ruiz: É. Mas também tem a coisa do tempo, o tempo no papel é...

CB: É livre?

Alice Ruiz: É livre, e o tempo da música você não te pega no primeiro verso não pegou. Pode pegar musicalmente a canção. Não sei como é na canção, a música, mas eu acredito que o mesmo sirva para a música.

CB: É.

Alice Ruiz: Tem que conquistar nos primeiros acordes.

CB: Isso. E tem...

Alice Ruiz: A letra também, pega atenção da pessoa já, de cara, ou não pega. 
CB: Isso que é muito interessante, porque as notas são as mesmas, as notas musicais são as mesmas, as palavras são as mesmas e ele...

Alice Ruiz: Mas nós...

CB: A combinação. Com a combinação.

Alice Ruiz: É.

CB: Pensando nas parcerias mesmo...

Alice Ruiz: Ah, deixa eu só complementar uma coisinha, querida, em relação a isso que você falou. É claro que me deu mais garra como letrista esse trabalho próxima do Itamar, 20 anos de parceria são super marcantes. Mas eu sei assim, como o Itamar sabia também, eu acho que os músicos sabem, os compositores sabem, na hora que compõem uma música ou na hora que compõem uma letra, você sabe para quem que é. Então quando eu fiz Socorro, eu sabia que era para o Arnaldo. Apesar dele ser dos Titãs na época, e não ter a ver, mas pela minha amizade com ele, pelo que eu tinha sacado dele como músico, como pessoa, eu olhei e falei... sabe, as letras têm um pouco a cara...

CB: Um destino mais certo.

Alice Ruiz: Um destino mais certo. É.

CB: Mais certo de veiculação. O destino que vai tomar aquilo para quem escuta continua sendo...

Alice Ruiz: É um destino mais certo de parceria, para quem você vai dar aquela letra, no meu caso. Mas o resto é imponderável.

CB: Claro.

Alice Ruiz: Eu só queria complementar isso.

CB: A gente fica empolgada, eu fico falando e acabo cortando meus interlocutores.

Alice Ruiz: É porque o assunto te entusiasma também.

CB: Eu estava falando das parcerias mesmo. Que aí vocês dividiam letra, até essas parcerias... Primeiro, ele começou com essa ideia de utilizar os seus poemas, essas colchas, depois vocês começaram a escrever juntos.

Alice Ruiz: Não.

CB: Não? 
Alice Ruiz: Não. Ele fazia música para as minhas letras. São poucas as que nós escrevemos juntos. Quer dizer, a gente escreveu juntos, na verdade, uma só, que é Abobrinhas não.

CB: É única.

Alice Ruiz: É a única. O resto, ele, tudo, ele musicou as minhas letras.

CB: As suas letras, que você já pensou como sendo destinadas a ele?

Alice Ruiz: A ele. Mas em alguns casos, ele colocava alguma coisa a mais. Porque, lembra que ele adorava listas, não é?

CB Sim.

Alice Ruiz: Então, por exemplo, na Vê Se Me Esquece, que é uma carta pedindo de volta algumas coisas e devolvendo outras. E claro que ele aumentou coisas ali, nessa lista. Por exemplo, "a receita de quibe, de quiabo, de quibebe, do diabo que te carregue", é dele. Ele colou isso por conta dele, eu nem tinha está ferocidade na época, agora até tenho.

CB: Foi passando o tempo, foi ficando mais...

Alice Ruiz: Mas não tinha. Isso é dele, quer dizer, ele aumentou a lista, mas acho que é só isso. Em Milágrimas, ele colocou uma coisinha mais, que é, coma somente a cereja. Que tem é uma lista de coisas a se fazer para não chorar.

CB: Mas é bonito, porque aí a letra sugere que você pegue aquilo que seria o principal, sabendo que você tem poucas forças. Então você só pega aquilo que tem direito de pegar.

Alice Ruiz: É, eu tinha escrito só "coma a sobremesa". Quer dizer, eu dei para ele o link, e "coma somente a cereja" foi acrescentado, eu acho, por causa da métrica musical. Ele sentiu falta ali, de alguma coisa, para música que ele criou e botou a cereja na letra. Então acontecia isso, mas é raro, a maior parte são letras que eu dei. Ou, acontecia muito isso também, e aí era o momento da parceria maravilhosa, que é, por exemplo, eu levava embrião para ele, levava uma estrofe pronta apenas, que tinha ideia. Aí sentávamos e conversávamos, ele ficava lendo as letras que eu tinha levado, esses embriões, e pegava... aconteceu com Sei dos Caminhos, por exemplo, isso. Ele pegou, acho que tinha... "Sei dos caminhos que chegam, sei dos caminhos que se afastam. Eu conheço como começa e como termina o que faço, só não sei como chegar ao nosso próximo passo." Era isso que tinha. Ele fez a música, começou a música, em função da música, eu desenvolvi o resto da letra. Porque a música parece que direciona a emoção.

CB: Ela pega essência. 
Alice Ruiz: É. Pega e essência, mas também direciona a emoção para o letrista.

CB: É interessante, por exemplo, conversando com o Paulinho Lepetit, ele falou dos arranjos. Quando o Itamar estava era uma bagunça assim, quando eles iam fazer, produzir juntos um disco. Mas, por exemplo, essas coisas que ele fez no disco com o Naná Vasconcelos (Isso vai dar repercussão) ou Pretobrás III, ele pegou só o Itamar tocando o violão, só tinha essa referência.

Alice Ruiz: Era o que ele tinha.

CB: Isso, eu já tinha notado ouvindo as gravações, que tem muita informação musical, é muito grande a informação musical. É como se fosse um DNA ali, então ele simplesmente escutou o que o violão... o que a voz e o violão apresentavam, em termos de sonoridade, e foi distribuindo para os outros instrumentos. Então eu acho que tem uma coisa que percebo no Itamar, tal como se fosse uma gotinha, aquela chuva que cai no deserto. Bastam poucas gotas para começar a florescer. Porque tem uma essência ali que...

Alice Ruiz: Então, isso é uma característica do Itamar, o Paulinho Lepetit é cria do Itamar, ele tocou com o Itamar muitos anos. Então, eu comentei com o Lepetit, esse Pretobrás III... O que o Lepetit fez é a cara do Itamar, ele fez como o Itamar faria, eu acho.

CB: Justamente, ele falou assim: "Eu ouvi o que estava ali, de informação musical que é no violão, só..." Segundo ele: "Eu não fiz nada, eu só distribui para os outros instrumentos". Então manteve a essência. Então ligando o que você está falando, a música também possui um potencial de gerar, gerar um ambiente onde as palavras possam se...

Alice Ruiz: E o Ita tinha isso maravilhosamente. Talvez, até pelo fato dele ser um grande letrista, ele tinha uma compreensão da letra, que outra pessoa dava para ele, tão grande, que ele sabia aonde fazer as mudanças, por exemplo, a partir da letra. No caso de Milágrimas, que é essa série de coisas a se fazer para não chorar, naquele momento do: "Mas se apesar de banal, chorar for inevitável, sinta o gosto do sal, gota a gota, uma a uma...", esse momento é o momento de chorar. E se você olhar a musicalmente, ele criou uma... eu não sei dizer...

CB: Assim, tecnicamente, é que conta...

Alice Ruiz: É. Mas ele criou uma catarse ali. A catarse do choro está ali. Quer dizer, ele compreendia tão bem a letra que ele fazia o movimento da emoção certa. Devia ser proibido, por exemplo. Quando eu entreguei a letra, ele não mexeu em nada nessa letra, mas o que ele fez musicalmente, acrescentou... acrescentou não, mas ele colocou a minha emoção ali, na musica que ele fez. Porque ele era também uma das "viúvas" do Paulo (Leminski).

CB: Sim, sim. 
Alice Ruiz: Ele era apaixonado pelo Paulo. E ele viu quando leu a letra, sem que eu tivesse dito qualquer coisa, ele percebeu que era para o Paulo. $\mathrm{E}$ provavelmente se identificou com o que eu disse ali. $O$ que ele fez é exatamente o que eu faria se eu soubesse fazer música. É louco isso, eu sei que ele fez a música para o Paulo também.

CB: Sim.

Alice Ruiz: E essa música acabou se tornando para ele também.

CB: É, isso. Porque no fim se juntam as forças que estavam com a mesma frequência, ninguém vai ser o único dono daquilo.

Alice Ruiz: E aquela Ninguém me canta como você, que está no disco produzido pelo Paulo Lepetit também. Nasceu de uma brincadeira nossa, por telefone, que o Itamar falou: “Ah, agora você está...” Eu morava em Curitiba ainda, ele falou: "Agora você está fazendo parceria com essa meninada nova que está aparecendo." Todo ciumentinho. Daí eu falei: "Ah, Ita, não tenha ciúmes, não. Você sabe que ninguém me canta como você." Que é uma brincadeira com a ambiguidade, tal, daí ele falou: "Bacana isso aí, manda para mim, você escreve e manda para mim." E aí eu escrevi. Então era uma coisas tipo dedicatória para ele. Eu falei para você que eu não ia poder te ajudar muito, porque eu não tenho essa leitura crítica, assim, de literatura. Eu sou meio espontânea com o Itamar.

CB: Entendi. É difícil realmente explicar porque... ficar tentando achar que é possível encontrar, os motivos pelos quais ele tenha "feito isso" ou "aquilo". Mas, você só contextualizando um pouco já ajuda a esclarecer...

Alice Ruiz: Mas voltando àquela coisa que você estava falando, eu quero falar sobre isso, do Itamar não ter...

CB: Formação.

Alice Ruiz: Formação, é. Às vezes, principalmente quando se tem o dom, quando se tem a vocação, eu acredito que até funcione melhor você fazer a tua própria formação. Porque, ao mesmo tempo que o Itamar não tinha essa formação acadêmica ele estava ocupado com música o tempo inteiro. Ele trabalhava, ele estudava por sua conta aquilo que the interessava, aquilo que ele elegia o tempo inteiro.

CB: Isso eu tenho certeza assim, não existe mágica, ele estudou, só que ele estudou, ele sozinho. Então, nesse ponto, até você concorda que essas coisas mais espontâneas, se a pessoa fizer esse caminho, ela fica mais livre? (falas sobrepostas) Talvez não tenha muito a ver com...

Alice Ruiz: Não, eu concordo com você. Não, e acho que tem a ver sim. Se você vai falar do processo de composição do Itamar, tem tudo a ver, tem tudo a ver. Mas eu não gostaria de colocar assim como isto é melhor do que aquilo. 
CB: Claro, porque não é verdade.

Alice Ruiz: Não, é porque cada um tem um caminho. O caminho do Itamar foi esse.

CB: Por isso talvez seja tão singular ter um caminho...

Alice Ruiz: Não sei qual é a formação musical, por exemplo, de Caetano Veloso, de Gilberto Gil, eu também não sei. Mas de Edu Lobo, eu sei. E, no entanto, eu prefiro Caetano e Gil, a Edu Lobo. Eu acho que é a coisa de você ter o que dizer.

CB: A gente volta nisso também.

Alice Ruiz: Tanto em termos de pensamento quanto em termos de sentimentos, é ter o que dizer.

CB: Nisso está bem em acordo com o que o Arrigo falou, assim: "Bom, tem gente que escreve música, mas não tem..." É nessa mesma ideia, não tem o que dizer.

Alice Ruiz: Não acrescenta nada, não acrescenta.

CB: Está reproduzindo. Na verdade, ele colocou essa questão, de ser uma coisa no momento de valorizar aquele um instante lá, que até na interpretação. Que eu estava perguntando para o Arrigo especificamente, se a música dele requeria alguma coisa para ser executada. Porque, às vezes, eu vejo a música do Itamar sendo tocada e as vezes de uma forma assim meio...

Alice Ruiz: De quem não entendeu...

CB: De quem não entendeu.

Alice Ruiz: Eu também, eu também.

CB: Porque tem muita sutileza ali e, de repente, passa por cima.

Alice Ruiz: É. Sim.

CB: Musicalmente, eu posso até explicar de alguma maneira porque isso. Mas tem a coisa do intérprete que vai cantar, que vai falar aquelas palavras. É tudo junto, a gente não consegue separar. Mas aí...

Alice Ruiz: Tanto que ele não gostava muito que outros interpretassem suas coisas.

CB: Ele era bem reticente, se fosse gravar tinha que pedir, lá, pelo amor de Deus. 
Alice Ruiz: Não, ou ele acompanhava, como no caso da Alzira. "Então está bom, mas eu produzo..."

CB: "Eu controlo"

Alice Ruiz: Exatamente.

CB: Tem razão e não tem, tinha certo exagero, mas tem razão...

Alice Ruiz: Quando você olha os resultados, você vê.

CB: Que fica banal, você fala: "Bom, do Itamar é isso?" Não, é porque tem muita coisas sendo feita, que precisa estar atento para...

Alice Ruiz: Por isso que eu elogiei o Lepetit nesse disco, porque, claro, é o Itamar que está cantando. Mas todo o trabalho, todo o arranjo musical que o Lepetit fez é a cara do Itamar.

CB: Porque ele fez respeitando, ele falou mesmo: "Eu respeitei, eu peguei aquele DNA que estava ali, no violão", e só espalhou. Uma coisa que já me lembrei. Porque a gente estava falando do aspecto rítmico que era muito forte, mas depois, quando ele vai, essa é a impressão que eu tenho, quando ele entra nessa ideia da letra, não importa muito o arranjo, tem o que os instrumentos vão fazer...

Alice Ruiz: Não, aí o que importa é a voz dele.

CB: Então, é a interpretação. E as canções começam a ter assim uma coisa, elas já tem uma autonomia maior ligada com a pessoa dele, ou não? Quando ele começa a fazer, por exemplo, Milágrimas, tem um outro nível de sutileza, que aí não precisa ser o Itamar cantando. Eu percebo umas canções que podem ser tocadas só voz, violão, pode ser feito o arranjo que for feito, que tanto faz, porque ela já tem uma... no início da carreira dele está muito atrelado ao show, a figura dele, aos instrumentos. A ideia rítmica é mais forte, então você precisa de banda para tocar e não sei o quê, aí tem uma série da produção dele que são, justamente, as canções que têm mais leveza, são mais líricas. Então parecem que elas já são mais descoladas da pessoa dele.

Alice Ruiz: Espero que ninguém se aborreça com esse meu comentário, mas Ninguém Me Canta Como Você. É verdade, é verdade. As coisas que nós fizemos, cantadas por ele, tem uma força que nas interpretações eu não vejo.

CB: Não vê acontecendo.

Alice Ruiz: Eu não vejo.

CB: Então de qualquer forma, o intérprete, o cuidado ainda precisa ser extremo. Cuidado, a delicadeza de perceber. 
Alice Ruiz: E o que corrobora isso que você está falando, é que pessoas que foram mais próximas a ele, por exemplo, Alzira e Zélia, cantam melhor as nossas parcerias, minha e dele, do que outras pessoas que não foram tão próximas a ele. Quer dizer, a marca registrada dele aparece mais nessas pessoas que conviveram, porque conviver com ele não se separava a pessoa do artista. Você sabe disso.

CB: Sim. 24 horas, é uma overdose muitas vezes. Era difícil porque há momentos em que não se quer tanta a intensidade. Mas era 24 horas ligado.

Alice Ruiz: Era. Era.

CB: Por exemplo, os músicos, o Paulo, o Arrigo, o Paulo Barnabé, eles usaram muito essa palavra "aprender a linguagem do Itamar", "a linguagem musical", como se tivesse um idioma ali, que fosse pertencente ao Itamar, que ele tivesse criado. Eu não estou sabendo perguntar agora...

Alice Ruiz: Mas eu acho que eu sei que você quer saber. Se em termos de letra era assim também, quer dizer, tinha uma... Agora, no caso dele, eu acho que as nossas parcerias aconteceram porque havia uma afinidade entre a linguagem musical dele e a minha linguagem verbal. $O$ que aproximou foi a afinidade, primeiro. Depois, a gente acabou se influenciando mutuamente, mas primeiro houve a afinidade.

CB: E essa ideia de que você falou, de ter o que dizer, querer dizer.

Alice Ruiz: Sim.

CB: O Arrigo também falou muito disso, da pessoa ter uma necessidade de dizer. Não é que ele precisa falar qualquer coisa, ele tem que dizer, e isso é uma necessidade vital para ele. Até para que sintetizasse a ideia musical própria.

Alice Ruiz: Eu acho que os que produzem boa arte são assim. Não é ele. Acho que quem faz boa poesia, qualquer boa arte, arte de qualidade é assim.

CB: Uma necessidade.

Alice Ruiz: Tem esse anseio de achar a linguagem certa, achar a expressão certa daquilo que tem a dizer.

CB: Que vai chegar em uma forma. Então o perigo é esse: eu vou dizer com o trabalho qual é a forma que ele chegou. Mas isso não quer dizer que você usando aquela forma você vai ter a... se alguém olhar o trabalho que vai ser feito: "Aqui, o Itamar usa isso, aquilo, aquilo, aquilo...", você chega em uma catalogação, dissecação ali, mas isso não quer dizer que que alguém pegando aquela casca vai conseguir fazer.

Alice Ruiz: Não, nunca. 
CB: Por isso é uma contradição do trabalho do estudo, na verdade.

Alice Ruiz: Mas não sei se é, não sei se é. Porque não existe receita. Não é uma receita, você não pode "desnudar" tudo, em termos técnicos, mas sempre haverá a chama insubstituível daquele artista, no caso, totalmente, insubstituível em se tratando de Itamar.

CB: Mas é engraçado pensar assim.

Alice Ruiz: É. (risos)

CB: Porque ao mesmo tempo acho que precisa, porque essas informações todas podem sumir. Eu não sou nenhum pouco saudosista, e não acho que faltem coisas boas sendo feitas. Mas é uma maneira de fazer... por isso eu estou conversando com as pessoas. Porque, primeiro, uma pessoa não realiza nada sozinha, e as pessoas que conviveram com ele entendem as circunstâncias. No trabalho do Itamar essas pessoas estão presentes. Acho que é bem típico de música popular, esse "fazer" na prática.

Alice Ruiz: Sim. Coisa da troca.

CB: Alice, eu acho que é isso.

Alice Ruiz: Espero ter ajudado.

CB: Eu acho que sim. Eu tenho que ir refletindo, pensando nas coisas. Mas eu acho que é isso. Se você se lembrar mais de alguma coisa, a gente...

Alice Ruiz: Ainda bem que tem e-mail.

CB: Papo bom, quase uma hora aqui de conversa.

Alice Ruiz: Ah, é! 


\section{b) Conversa com ARRIGO BARNABÉ}

Clara Bastos: A ideia desse mestrado, para mim, foi natural. Como eu havia feito o songbook, já estava tudo transcrito, então era só olhar o material. Lógico que não é só assim que a gente pode ver o Itamar, não é através da partitura.. Não tem como explicar o Itamar. Como muitas coisas em música, tal. Eu acho que é registro importante. É um jeito muito peculiar de fazer música. Que ele foi chegando, desenvolvendo. Foi uma confluência de coisas, não é?

Arrigo Barnabé: Sim.

CB: Eu tenho um monte de pergunta, a gente vai conversando.

Arrigo Barnabé: Sim.

CB: Como se explica uma pessoa como o Itamar? Que ele tenha chegado à síntese que ele chegou? Talvez essa pergunta seja difícil de ser respondida, não é?

Arrigo Barnabé: Como assim? Não estou entendendo bem o que você está perguntando.

CB: A música vai tendo um caminho, quer as pessoas tenham consciência disso ou não. A música popular, vamos dizer assim. A gente não pode dizer...Tem linhagem...

Arrigo Barnabé: O Itamar tinha muitas, como se diz, dificuldades, desconhecimentos, havia muitas coisas que ele não conhecia, que ele não sabia. Não conhecia harmonia. O conhecimento dele em harmonia era de iê, iê, $i e ̂$, quase. Pequeno, sabe? Isso é uma diferença com outros caras como... Porque têm outros caras que têm o controle maior do processo de harmonizar, de pensar harmonicamente. Por exemplo, o Luiz Melodia tem conhecimento de harmonia mais complexo. O Itamar, ele era limitado nesse ponto, entendeu?

CB: Sim.

Arrigo Barnabé: E dessa limitação dele, ele fez um recurso.

CB: Ele é extremamente inteligente.

Arrigo Barnabé: Eu acho que foi uma coisa assim: "Eu vou me virar com o que eu tenho. E vou me virando com o que eu tenho, porque eu tenho essa necessidade..."

CB: Que é uma necessidade vital .

Arrigo Barnabé: Vital. 
CB: Tem essa coisa muito forte: "Eu tenho que fazer isso", é uma missão sei lá o que.

Arrigo Barnabé: Ele tinha essa necessidade de fazer. Que isso dá para o trabalho dele uma autenticidade, uma integridade. Porque você percebe que é uma coisa honesta, que vem da necessidade que ele tem de fazer. Não vem porque ele está querendo fazer música popular brasileira. Não tem nada a ver. Ele precisa fazer. E ele pega, trabalha com as limitações dele, resolve esses problemas de forma muito criativa. Então você vê que engraçado, as coisas que o Itamar fazia no início eram melodia acompanhada. Ele tinha um suingue muito bom no violão, algumas batidas ele aprendeu com o meu irmão, 0 Paulinho (Paulo Barnabé), que tem muito suingue no violão também. Tocava umas batidas, o que dava uma coisa interessante, mas ainda não era um negócio descolado da melodia, do acompanhamento.

CB: Da referência que ele tinha também, de música popular. Referência sempre é isso, melodia acompanhada, música popular, basicamente.

Arrigo Barnabé: Sim. Ele ainda não percebia que o João Gilberto fazia uma coisa no violão e outra coisa na voz. Que tinha uma independência. Então ele fazia umas coisas simples assim, eles e os irmãos fazendo ponto, tocando atabaques, uma coisa quase folclórica. E fazia umas músicas, meio de protesto, ele era muito cercado pelo "pessoal de esquerda".

CB: É. Não era essa nomenclatura, mas a gente entende, que tem uma coisa bem da época. Era muito mais cindido, direita, esquerda, o bem e o mal.

Arrigo Barnabé: Não, tinha um negócio, aqueles caras que não gostavam muito do tropicalismo.

CB: Sim.

Arrigo Barnabé: Nem do iê, iê, iê, sabe, nem do rock. Entendeu?

CB: Sim.

Arrigo Barnabé: Esses caras viviam ali. Ele vivia nesse meio, foi criado nesse meio, culturalmente. Não estou falando que ele ouvia, do que ele gostava de ouvir. Mas estou dizendo quando começou a refletir sobre isso, ele começou a refletir nesse ambiente. As pessoas fazendo a cabeça dele. Então ele não tinha essa preocupação, exatamente musical. Ele tinha um negócio meio ligado a canção de protesto, um pouco ligado a canção de protesto, sempre com essa de reclamar, "Prezadíssimos ouvintes, boa noite, boa noite. Pra chegar aqui, tive que fazer não sei o quê." Sempre reclamando das penas...

CB: Isso é um traço que a gente vê também na música dele. Alguma...

Arrigo Barnabé: Isso foi muito estimulado por esse pessoal de esquerda. 
CB: Mas você vê, sempre sobra um pouquinho. Mesmo depois fazendo outras coisas. Tem várias características dá para perceber, de temática, que já estão desde o começo, que depois ele desenvolve, mas sempre sobrou um pouco essa de reclamação, de falação, não é?

Arrigo Barnabé: É. E é um negócio como se você fosse obrigado a fazer as coisas para ele. Porque você era branco e tinha uma condição um pouco melhor que a dele. O Itamar não era um cara que tinha uma condição social ruim, o pai dele era fiscal de café do IBC ${ }^{177}$. Não é um indigente.

CB: Claro.

Arrigo Barnabé: Sabe? Fiscal de café do IBC, é um emprego vitalício. Não é que o cara... Mas eles cultivavam essa imagem. E o Itamar era "casca grossa", não era universitário. Não chegou a ter assim nível universitário. Ele foi estimulado por esse grupo, para intensificar essa revolta dele, sabe, que às vezes eu nem sei se ele tinha essa revolta no começo. Os caras começam a chamar atenção. Quer dizer, claro que a coisa racial é evidente, isso existia mesmo.

CB: Mudou muito, mas ainda existe, é subliminar, não é?

Arrigo Barnabé: Nossa Senhora!

CB: Mas daí pega por aí, um cara que tem também o sangue quente, fica mordido, de repente, e o problema nem lhe atinge tão frontalmente...

Arrigo Barnabé: É. Então o cara quer reclamar: "Estão contra mim." Mas ele teve essa formação, com esse grupo aí, que meio adotou ele, tal...

CB: O grupo de teatro lá?

Arrigo Barnabé: Isso o grupo de teatro da Nitis ${ }^{178}$. Então aí que ele deve ter começado a ouvir algumas coisas, tipo Geraldo Vandré, enfim, esse pessoal do Centro Popular de Cultura, CPC, essas coisas, sabe, existia aquela mentalidade. E então ele via as coisas desse jeito. Agora, ele tinha uma voz muito bonita e cantava algumas coisas, cantava umas músicas do Milton Nascimento, San Vicente, não, cantava Dos Cruces. "Están clavadas dos cruces...", cantava isso. E tinha uma figura cênica impressionante. Quer dizer, eu estou me lembrando das vezes em que eu o vi cantar, assim, a primeira vez. Ele era um cara que tinha esse material. Ele podia pensar em fazer essas coisas, fazer música, tudo isso. Mas fazia um negócio simples, muito simples. Ficava: "lá, sol, fá, mi”.

CB: Ele manteve também, não é?

Arrigo Barnabé: Manteve, ele não mudou isso.

\footnotetext{
${ }^{177}$ Instituto Brasileiro do Café.

${ }^{178}$ O GRUTA (Grupo de Teatro de Arapongas) dirigido por Nitis Jacon.
} 
CB: Não mudou. A intervenção é justamente quando entra essa questão que você ia falar, de perceber, a possibilidade do contraponto, não é?

Arrigo Barnabé: Quando ele veio para São Paulo, veio morar com a gente, eu tinha participado em um show lá em Londrina na Boca do Bode ${ }^{179}$, eu tinha uma participação muito pequena, que já era Clara Crocodilo numa outra forma, uma forma muito mais simples, mas já tinha essa coisa do baixo ser independente. Depois eu escutava esses grupos de rock, tinha muita linha de baixo independente. Linha de guitarra. Pô o próprio Alice Cooper tinha linhas super legais. Com contraponto e tal. O Itamar, ficava ele e o Paulinho, lá onde a gente morava, eu, o Rubão, o Guará, ele... você conhece o Guará, não é?

CB: O Guará, eu conheço de nome.

Arrigo Barnabé: O Guará fez o Chavão. O Guará é uma figura.

O Itamar e o Paulinho ficavam lá o dia inteiro escutando e tirando as linhas, entendeu? Mas ele ainda não se atrevia a fazer. Aí um dia, acho que foi 1976, 1975, já fazia um ano que ele estava morando aqui em São Paulo, um ano e meio, ele apareceu com uma linha de baixo. Primeira linha que eu o vi fazer. Que é aquela música, eu e o Paulinho fizemos juntos ${ }^{180}$, aquela que fala assim: "te, ga, re, ga, ra, ta, ti, ta, ti", O que é o quê? Mi bemol, fá, mi bemol, fá, lá bemol... Aí fá bequadro,... É fá sustenido, "te, ga, re, ga, ra, ta, ti, ta, ti", aí vem si si, aí vem fá bequadro, um trítono, vai para o mi, aí vai pro sol sustenido, ré, si bemol, mi, dois trítonos. Então aí você vê, já, uma ideia completamente diferente. Fez essa frase, aí começa: tá, tu, re te, tá, di ra, ta..., eu tirei do piano. Aí depois o Paulinho fez aquela parte final, ele juntou as coisas, colocou a letra também. Aí ele começou a ter uma visão disso. E aí, nessa história, eu não me lembro, mas ele e o Paulinho ficavam juntos fazendo um monte de coisas. Por isso que eu te falei, o Paulinho pode falar mais sobre isso, porque...

CB: Sobre esse momento aí, da...

Arrigo Barnabé: Dessa formação auditiva dele. Eu lembro quando ele apareceu com Luzia, que também era uma melodia acompanhada, ainda. Quer dizer, eu achava interessante, mas musicalmente, eu sou mais ligado na música, não via nada de especial... Aí ele foi fazendo, fez o Fico Louco. Eu me lembro que nós montamos um conjunto para gravar um disco, o Rogério Duprat ofereceu o estúdio, eu tinha que ter um conjunto, então fizemos um grupo, que era eu de piano, Antônio Carlos Tonelli no baixo, Paulinho Barnabé na bateria, e o Itamar cantando, as mesmas músicas, Sabor de Veneno, Clara crocodilo. Ensaiamos durante seis, sete meses, mas as músicas eram muito difíceis, a gente não conseguia levar em frente. O Itamar não era adequado para cantar aquilo, porque não era a onda dele. E aí a Zena ficou grávida da Serena, aí o Itamar chegou, falou: "Olha, a Zena ficou grávida, eu vou ter que trabalhar." E aí, separamos, cada um foi fazer uma coisa, eu voltei para ECA.

CB: Sim. Isso aí é setenta e...

\footnotetext{
${ }^{179}$ Nome do show ocorrido em Londrina, em 1973, no Teatro Universitário, com os compositores que haviam sido revelados nos festivais universitários. (GIORGIO: 2005)

${ }^{180}$ Canção Tô tenso, parceria entre Arrigo, Paulo Barnabé e Itamar.
} 
Arrigo Barnabé: 1977. Aí fiz a ECA, continuei fazendo lá os meus cursos. Foi nesse período que eu comecei a conhecer o dodecafonismo, foi aí. Eu já tinha feito Clara Crocodilo, e um monte de coisas.

CB: Eu acabei dando uma lida na entrevista a Renata Jamberg, em que você já falou sobre isso, sobre suas músicas só para não ficar redundante.

Arrigo Barnabé: Sim.

CB: Então justamente, você já compunha músicas que se aproximavam dessa sonoridade, mas sem conhecer, não é?

Arrigo Barnabé: Sem conhecer. Era um desespero, porque eu tinha que ficar criando regras internas, para estabelecer um nexo nas coisas.

CB: Claro. Você falava: "Eu sou maluco."Não é?

Arrigo Barnabé: Não, eu falava: “De onde os caras tiram?" Porque eu escutava as coisas do Bella Bartok as coisas do lgor Stravinsky, eu falava: "De onde o cara tira isso?" Eu pensava muito em relações intervalares. E aí, o Itamar foi trabalhar com correio, alguma coisa.

CB: Ele entregava imposto, não era uma coisa assim?

Arrigo Barnabé: Isso. Entregava imposto. Aí ele fez um trabalho com o Amiro. O Amiro era um cara que fazia música também, mas nessa onda de MPB, foi sócio do Amiro, ele e o Amiro tiveram alguma coisa juntos. E o Paulinho foi para outro lugar.

Arrigo Barnabé: É, enfim. Aí eu fiquei na lá ECA, me envolvi mais nas aulas do Willy (Correa de Oliveira), comecei a trabalhar, enfim, minhas coisas, tal. Aí comecei compor aquelas coisas, sempre tentando entrar em um festival, outro. O Itamar começou a tocar com o Jorge Mautner, se não me engano...

CB: É isso.

Arrigo Barnabé: A gente se encontrava às vezes, tinha um grupo que cercava o Itamar, aqui em São Paulo, e que dava uma segurança para ele. Era eu, a minha mãe, morava aqui, o Paulo, o Tonelli, o Sergio Guardado que era muito próximo dele, a Eliete Negreiros, a Eliene Guindi, a mulher do Sergio, a Marta, a irmã dela, a Betânia Amoroso, então o Itamar tinha um grupo de conforto, que dava...

CB: É, isso ele sempre precisou, dependente num certo sentido.

Arrigo Barnabé: É.

CB: Para as coisas da vida assim...

Arrigo Barnabé: Da vida. 
CB: O cara não...

Arrigo Barnabé: É. Ele ficou meio acostumado com isso.

CB: É. A ser paparicado, não é?

Arrigo Barnabé: Mas enfim, ele... O que eu estava te falando mesmo?

CB: Acho que a gente estava tentando chegar na questão de como que ele conseguiu definir o estilo dele, não é?

Arrigo Barnabé: Aí o que aconteceu?

CB: Os festivais lá, daí entrou...

Arrigo Barnabé: Aí eu fazendo algumas coisas e tal, o Itamar estava tocando com o Jorge Mautner, enfim, a gente se encontrava às vezes, a gente tinha esse grupo, essa turma. Eu lembro da gente indo visitar a Serena, pequenininha, lá na Penha. Aí eu conheci a Tetê Espíndola nessa época, 1978, chamei a Tetê para cantar comigo no festival da Revista de Música do Grupo AMA...

CB: Ah, sei. Daquela revistinha Vigu ${ }^{181}$, ou não?

Arrigo Barnabé: Vigu, é, é. Aí a Tetê foi cantar comigo Outros sons. Enfim, e eu na batalha, e eu chegando na forma do Clara, fazendo Diversões Eletrônicas, tudo ainda em processo. Aí pintou o Festival da TV Cultura, eu coloquei as músicas e classifiquei Diversões e Infortúnio. Eu chamei o Paulinho e o Itamar para fazer o arranjo de base, porque era um negócio que eu via eles o dia inteiro fazendo, "tuc, tuc, tuc, prof, bum".

CB: Você sabia que eles iam resolver.

Arrigo Barnabé: Eu falei: "Eu quero fazer essa...", são as pessoas que conhecem o meu trabalho, sabem como é que eu penso, não queria um profissional, não é? E aí o Itamar estava tocando baixo, eu achava demais o jeito que ele tocava baixo, assim, o baixista que eu mais gostei de tocar foi ele. Sabe?

CB: É impressionante, não é?

Arrigo Barnabé: Eu achava demais.

CB: O Arthur Maia uma vez falou para ele, assim: "Ai, você é o melhor baixista que eu já conheci." Alguma coisa desse tipo. Ele ficou bravo, Mas ele estava falando sinceramente mesmo.

\footnotetext{
${ }^{181}$ Revista Violão e guitarra, com letras cifradas, editada pelo grupo AMA que era vendida nas bancas de jornal nesse período.
} 
Arrigo Barnabé: Eu achava demais. Eu adorava tocar com o Itamar. E aí eu chamei, aí fomos lá em casa para... Eu morava para lá do Butantã, e ficamos lá, eu, ele, o Paulinho, bolando as levadas, tal, e o Diversões era um baixo mais óbvio, mais claro, era em cima do que eu fazia no piano. O Infortúnio não, porque a linha da mão esquerda não era uma linha de baixo. Era uma linha de teclado, de contraponto. E aí eu falava para ele: "Itamar, então vamos fazer o seguinte, vamos fazer uma série dodecafônica aqui, mas não vai seguir a minha série, vai ser livre. Porque eu não vou ficar..."

CB: Controlando.

Arrigo Barnabé: Vai ser livre, vamos usar as doze notas. E aí eu ia tocando, ele ia pensando o ritmo, e o Paulinho ia pensando em sistemas de condução, enfim, e ele falava: "Essa nota pode?" Eu falava: "Pode." "Essa aqui não, não pode." "Essa aí pode." E foi assim. Aí fizemos a participação no Festival da TV Cultura. Quer dizer, daí já foi uma grande experiência, porque participamos com essas duas músicas, com essa linguagem, muito contrapontística. Depois teve o Festival da TV Tupi, onde o Itamar teve um destaque grande também. Ele e o Paulinho escreveram arranjo de base, mas eu não gostei, no final, e na última apresentação, eu mudei o arranjo de base do Sabor de Veneno. Escrevi outra coisa, falei: "Não, vou fazer outra linha de baixo." E fiz esse arranjo que ficou no disco...

CB: Que acabou ficando, não é?

Arrigo Barnabé: Mas é mais ou menos essa aí.

CB: E nesse Festival, ele teve destaque porque?

Arrigo Barnabé: Porque falava: "Sabor de quê?"

CB: Ah, sim, entendi.

Arrigo Barnabé: "Sabor de quê?" Então ele tinha uma presença, muita gente achava que eu era um negão.

CB: Sim. Porque achavam que o Arrigo era o Itamar.

Arrigo Barnabé: É. Tanto que um argentino, escutou o meu som, ele perguntou para o amigo dele, que era uruguaio, "Quem é esse cara, como é que ele é?" O amigo respondeu: "É um negão." $\mathrm{E}$ aí o Itamar apareceu com o Nego Dito. Ele mostrou para mim o Nego Dito, grande música. E aí já tinha um negócio meio indo para o outro lado. Aí ele já começava a falar muito em fazer baixo, sabe? Ele tinha feito esse trabalho comigo (porque com o Jorge Mautner ele tocava percussão), fazendo baixo, e era super... então já estava tocando 0 baixo e pensando nas linhas, já estava funcionando na cabeça dele.

CB: Sim. Tinha dado um start. 
Arrigo Barnabé: Start. E, aí ele entrou no Festival da Feira da Vila Madalena, tirou o segundo lugar, o Nego Dito. Você acredita? O que é um festival? O cara tirou o segundo lugar! E aí ele começou a fazer o quê? Eu o chamei para trabalhar comigo baixo, na banda Sabor de Veneno, ele falou: "Não, Arrigo, não dá, porque eu vou fazer meu som, tal, não vai dar. Não vai dar tempo." Falei: "Pôxa, Itamar, vem, cara." Aí veio no lugar dele o Otavinho ${ }^{182}$, que era um cara legal, tocava muito bem e tudo, mas era muito assim certo, sabe? Não tinha invenção. Não era uma pessoa que tinha invenção.

CB: Essa coisa da criatividade é muito legal, é muito importante, não é?

Arrigo Barnabé: É. Eu acho demais. Porque é uma forma colaboração. Eu lembro que na gravação do Infortúnio, que a gente fez, no disco da TV Cultura...

CB: Sim.

Arrigo Barnabé: No disco do Festival Universitário...

CB: No Festival. Sim.

Arrigo Barnabé: Você já ouviu isso?

CB: Não, nunca ouvi.

Arrigo Barnabé: O Itamar fazia um negócio no baixo, que eu mostrava para o Otavinho, falava: "Tavinho, quero isso." Ele falou: "Isso, eu não consigo." Porque ele fazia umas... ele se desprendia ritmicamente, dava aquelas desligadas ritmicamente, assim, e voltava certinho, sabe, era demais mesmo. Então ele já estava assim, quer dizer, no elemento dele. E não quis fazer comigo a banda Sabor de Veneno, começou a montar o trabalho dele. E aí começou a montar, já, com essas coisas todas, entendeu? E aí ele começou a fazer participações nos meus shows. Abrindo os meus shows. Acho que a minha banda tocava com ele.

CB: Era a mesma banda?

Arrigo Barnabé: Eu tenho a impressão que era. E ele passava as linhas. Eu lembro do Bozo escrevendo umas coisas de metais para ele.

CB: Mas escrevendo as ideias que ele tinha ou ele mesmo...

Arrigo Barnabé: Não, ideias que o Itamar tinha. E ele passava as frases, que o Paulinho tocava com ele, o Paulinho era o baterista da banda, então era o Paulinho, o Tavinho, acho, e o outro menino lá, o...

CB: Ah, mas aí o Itamar não tocava baixo?

${ }^{182} \mathrm{O}$ contrabaixista, já falecido,Tavinho Fialho. 
Arrigo Barnabé: Não, não. Talvez tocasse baixo. Não sei, não me lembro. Talvez tocasse violão. Mas acho que não, porque o Itamar ficava na frente mesmo. E era um sucesso. E aí já estava configurado, a cabeça dele começando a rolar as coisas, não é. Então, acho que...

CB: Com essa convivência certamente, ele pegou essa coisa sua por tabela não?

Arrigo Barnabé: É, porque a gente trabalhava juntos.

CB: Mas não se trata de dizer: "Eu ensinei o Itamar."

Arrigo Barnabé: Não, não. De jeito nenhum.

CB: Mas certamente ele ficou ligado nisso, não é?

Arrigo Barnabé: Como eu também. Há muita coisa rítmica no meu trabalho, que eu via nele e no Paulinho. Porque eram ideias que tinham um pulso rítmico que eu não tenho naturalmente.

CB: Sim. Não é...

Arrigo Barnabé: Eu sou um cara mais de outra área, e eles são muito mais ligados na música popular mesmo, no suingue.

CB: E "físicos" assim, não é?

Arrigo Barnabé: Físicos.

CB: Da manifestação do som no corpo.

Arrigo Barnabé: É. Ele tem uma facilidade intuitiva, que eu não conseguia. Eu não tenho, realmente não tenho. Mas então eu peguei um pouco dessas coisas.

CB: Então a influência é certamente mútua?

Arrigo Barnabé: Com certeza. Com certeza.

CB: Independente até da amizade, não é?

Arrigo Barnabé: Ah, isso é convivência. Não, isso aí é convivência. Porque você está convivendo com o cara, está vendo as coisas de... Uma pessoa que tinha muito esse aspecto do suingue era o Bozo, pensava muito nesse ponto de vista do suingue. O Bozo não gostava do Itamar, não gostava da música do Itamar. Ele, até agora, não gosta. Ele não entende. Ele não entende. Tem gente que é assim, não é?

CB: É. 
Arrigo Barnabé: Tem músicos que...

CB: É, que...

Arrigo Barnabé: É a coisa da harmonia.

CB: É, de achar que... Porque assim, sei lá, a música africana não tem harmonia, sei lá.

Arrigo Barnabé: Não, o cara está vendo que...

CB: É outra coisa, não é...

Arrigo Barnabé: É outra área. O sujeito está criando. Ele está criando. É uma obra litero-musical.

CB: Sim.

Arrigo Barnabé: Não é obra musical.

CB: Sim.

Arrigo Barnabé: É obra litero musical. Então a música está livre, relacionada com o significado das palavras, com tudo.

CB: Tem tudo a ver com a performance do...

Arrigo Barnabé: $\mathrm{E}$ o aspecto forte dele era o ritmo. O ritmo era muito forte.

CB: Aliás, é interessante, porque não há nenhuma música que tenha fórmula de compasso diferente. Às vezes aparece um compasso diferente no meio. Em geral todas as músicas são quatro por quatro.

Arrigo Barnabé: É.

Clara Bastos: Mas mesmo assim é impressionante, tinha um momento assim, ensaiando: "Cadê o um?" De não se saber, quando ele ia montando aquelas frases...

Arrigo Barnabé: Sim.

CB: Não se saber onde é o começo, mesmo sendo quatro por quatro, falar: "Não, mas espera aí... Não, a frase está invertida...". Ele sabia muito bem o que estava fazendo.

Arrigo Barnabé: Você quer ver? Tinha uma música do Robson... Ele foi colocar, acho que, no show Boca do Bode, eu escrevi o arranjo na música, acho que o Itamar depois cantou, a música era muito simples. (Ao piano) "Eu acho que você não sabe não. A falta que você me faz. Até no ar que eu respiro, sinto falta seu sangue. Rita, Rita, Vampiro..." E é uma letra interessante, falar, e por fim, Rita o amor entre um Morcego, é um amor cego. Então eu fiz (ao 
piano) "Eu acho que você não sabe a falta que você me faz. Até o ar que eu respiro... Rita, Rita Vampiro...". Eu fiz esse baixo, mas eu não conseguia cantar direito, tal. Aí o Itamar fez uma batida no violão, mas ele tocava isso no... a gente fez alguns shows, fizemos Coração de Árvore, era demais. O Itamar fez uma batida de violão muito boa. Eu sei mais ou menos, e é isso aqui, acho que é isso aqui. Eu não vou conseguir fazer a batida que ele fazia. Aí ele cantava: "Ah, eu acho que você não sabe..." Era demais. Aí tinha, já, um negócio de ter uma independência dessa batida...

CB: Você falou do João Gilberto lá, que você falou, de ter essa sacação, porque tinha que fazer uma coisa e tocar outra.

Arrigo Barnabé: E já começou, sabe, e isso era... Porque, você vê, eu fiz uma linha de baixo...

CB: Que era em cima, que era colada...

Arrigo Barnabé: Independente da voz. Porque a voz: "Ah, eu acho que você não sabe, não, a falta que você..." Era um negócio quatro por quatro. Eu fiz um seis por oito.

CB: É.

Arrigo Barnabé: (música) Aí o Itamar... Aí foi intuitiva, a coisa que veio, um grande suingue. E era demais. Era muito legal.

CB: Uma questão que eu conversei com o Lepetit também, o Paulinho, e aí eu já tinha reparado isso, ouvindo a gravação do Itamar só tocando violão, mais para a frente, que ele só está fazendo a batida e têm um monte de vozes. Naquela coisa de ele tocar...

Arrigo Barnabé: Sei.

CB: É impressionante. Até o Paulinho falou: "Olha, as ideias todas, eu tiro dessa..."

Arrigo Barnabé: A mão direita.

CB: "Eu tiro dessa... todas as informações, eu espalho para os instrumentos, mas elas estão nessa batida do violão."

Arrigo Barnabé: É.

CB: Que depois, ele foi refinando assim, rela o dedo numa corda, começa aparecer umas vozes ali.

Arrigo Barnabé: Não, ele foi descobrindo.

CB: É. 
Arrigo Barnabé: Porque ele já sabia que aquilo era legal, porque aquilo ele sempre fez.

CB: Claro.

Arrigo Barnabé: Ele sempre fez aquilo. Ele só... chegou num momento em que ele percebeu...

CB: Isso aqui é bom.

Arrigo Barnabé: Isso aqui é bom. Quando ele fez essa batida, isso aí foi em 1975, quer dizer já tinha então esse lado. E ele tinha essa coisa rítmica, muito forte.

CB: Então eu acho que é isso que predomina, não é, assim...

Arrigo Barnabé: Ah, eu acho que o ritmo é...

CB: E você acha que havia um samba implícito na música dele?

Arrigo Barnabé: Ah, ele tinha muita facilidade com o samba. Os caras queriam que ele gravasse samba. A gente morava lá na rua Conselheiro Carrão, e eu lembro dele voltar da gravadora, ia tentar mostrar as coisas, ia na gravadora RCA, Copacabana. "O cara quer que eu mostre disco de samba", que é Jorge, não sei o que, Jorge Arão..." E num dia em que ele foi lá ficou bravo, os caras queriam que ele gravasse um disco de pontos de umbanda (risos). Não, porque os caras queriam que eu fizesse um negócio, como é que se diz, uma coisa condensada, sabe?

CB: Sim.

Arrigo Barnabé: Vamos pegar um negócio aqui, fazer um "sambinha", fazer uns "pontos de umbanda". Um negócio industrializado, entendeu?

CB: Claro.

Arrigo Barnabé: $O$ que eu acho muito interessante também, é a forma como ele entendeu que podia revalorizar esteticamente essas coisas. Coisas que não tinham, a princípio, tanta qualidade estética, e que ele descobre, quer dizer, que percebe que pode...

CB: Atribuir valores a essas coisas...

Arrigo Barnabé: Por exemplo, tem algumas músicas dele, que eu conhecia dos anos 70. Ele tinha desistido das músicas. E, de repente, elas aparecem com uma outra interpretação, com arranjo, revelando um outro negócio.

CB: Não é que aquilo era ruim, ele que ainda não tinha descoberto.

Arrigo Barnabé: Não, não, não. Do jeito que ele tinha feito... 
CB: Ele tinha abandonado, mas não ia funcionar.

Arrigo Barnabé: Do jeito que ele tinha feito não era legal. Não era uma coisa legal. Eu o ouvia tocando, cantando a música e tal, sabe, dá para uma outra pessoa qualquer, fazer aquilo, você fala: "Isso não é legal." Agora, ele descobriu uma maneira de revalorizar isso. Quer dizer, coisas pequenas que faltavam, na realidade, para aquele negócio. Para ganhar interesse? Faltava pouca coisa. Mas como geralmente eram formas fixas, gêneros muito definidos, ele não conseguia sair disso. A partir de um momento ele consegue, ele começa a perceber e consegue sair do gênero, sair dos estereótipos.

CB: Sim. Que essa é a angústia das pessoas, às vezes, querem fazer música e ficam enquadradas ali, engessadas.

Arrigo Barnabé: Ele saiu... eu falo sobre essa questão em um dos Pretobrás.

CB: Dos primeiros. Ah, sim, sim, sim. Lógico, eu já li esse texto, sim, que é a abertura. Sim, sim.

Arrigo Barnabé: $O$ texto que eu escrevi?

Clara Bastos: Sim, sim.

Arrigo Barnabé: Que eu estou falando sobre como ele trabalha com as sequências harmônicas. Da mesma forma que um sujeito pega uma lata de óleo usada, abre ela e faz um vaso para plantar um gerânio, ele pega essas estruturas harmônicas super usadas, e utiliza essas estruturas harmônicas para produzir beleza.

Clara Bastos: Sim.

Arrigo Barnabé: Que trabalha com estereótipos. Ele descobre uma maneira de trabalhar com estereótipos. Tinham coisas que eram muito estereotipadas que ele fazia, são essas coisas que ele abandonou. Ele ficava procurando sempre uma coisa menos estereotipada, quando encontrou o Nego Dito. O Nego Dito é um negócio realmente bem resolvido.

CB: É impressionante, são dois acordes assim...

Arrigo Barnabé: Resolve tudo.

CB: É impressionante a força que tem.

Arrigo Barnabé: Mesmo Luzia. São coisas que ele consegue resolver um pouco ali. Mas o Nego Dito é...

CB: É. E é... 
Arrigo Barnabé: Depois você viu, Já deu para sentir também que é harmonicamente muito simples, mas é um negócio bem resolvido, muito bem resolvido, o Mal Menor, não é? Olha a harmonia do Mal Menor.

CB: É.

Arrigo Barnabé: Então é bastante coisa simples assim. Ele encontra... Quer dizer, ele pega esses estereótipos harmônicos e consegue usar isso quase que um cara que pega sucata e trabalha em cima da sucata.

CB: Você acha que a música dele precisa dele ou desse conhecimento, para ser bem tocada?

Arrigo Barnabé: Eu acho que tem que ter uma coisa rítmica. Eu acho que é fundamental ter um negócio rítmico. Se não tiver esse aspecto rítmico, a coisa...

CB: Volta para onde estava, não é?

Arrigo Barnabé: É.

CB: Porque eu vejo as pessoas, às vezes, tocando a música a música dele em shows por aí, procurando causar impacto pelo aumento volume sonoro ou pelo uso de elementos eletrônicos...tem algumas sutilezas que se perdem...

Arrigo Barnabé: Tem algumas canções, por exemplo, que você não precisa tanto do ritmo.

CB: Sim. Que são belas canções.

Arrigo Barnabé: São canções. E quando ele começa a escrever, mais, eu acho que é influenciada pelo Leminski e pela Alice.

CB: Sim. Exatamente. Essa coisa...

Arrigo Barnabé: Faz umas canções que o ritmo não é tão importante. É mais o negócio do lírico. Uma coisa lírica.

CB: $E$ às vezes nem tem arranjo mesmo, praticamente. Isso pode ser transformado, não é?

Arrigo Barnabé: E você pode tocar isso. Quer dizer, a única coisa que tem que ter é o trabalho de intérprete mesmo, no sentido de dizer as palavras, entender a densidade das coisas que ele está colocando. E saber trabalhar com isso. Tem o lado teatral, não na composição dele. Mas eu acho que é essa...

CB: Na ressignificação daquela música, quando você escuta e quando você vê ele no palco, aquilo tem outra dimensão, não é? 
Arrigo Barnabé: É. Ele quando compõe, acho que ele compõe pensando nele cantando, e ele pensa nele também como uma pessoa que está atuando no palco, com os recursos que ele tem de ator. Ele tinha muitos recursos.

CB: Sim. Então nesse sentido acho se essa música vai ser tocada, ela tem que ser levada em conta isso, não é?

Arrigo Barnabé: A pessoa tem que ter um viés de ator.

CB: Não é uma música que, em si, digamos assim, se sustentaria como obra?, Ela precisa dessa interpretação teatral... ou não?

Arrigo Barnabé: Não, eu acho que algumas coisas sim, se sustentam. Claro! Mas você pode cantar, isso depende do intérprete.

CB: Claro.

Arrigo Barnabé: Tem gente que não é intérprete, é crooner. Sabe? Crooner não serve para cantar as músicas do Itamar. O cara tem que ser intérprete. A Bethânia, uma Bethânia.

CB: Sim.

Arrigo Barnabé: Alcione não. Quer dizer, Alcione, não sei se é a pessoa exata, mas tem...

CB: Jorge Vercillo, por exemplo.

Arrigo Barnabé: É, o Jorge Vercillo ou não, mesmo a... sabe, a Elizete Cardoso, entendeu, que é uma...

CB: Também é crooner, não é?

Arrigo Barnabé: Que é uma pessoa que é quase crooner, sabe? O Cauby Peixoto, por exemplo.

CB: Isso, sim. "O cantor", tem a voz, é a pessoa.

Arrigo Barnabé: É.

CB: Você vai lá para ver, como visse aquele ator não é o personagem, é o ator, você já sabe que é ele, você quer ver, ele tem um carisma, tal, mas não traz... a música é somente um pretexto para ele estar lá, não é?

Arrigo Barnabé: É. E ele está recriando o momento. Está recriando, ele está inaugurando um instante ali. Ele não está repetindo, vamos dizer assim. Essa é a diferença.

CB: Claro. 
Arrigo Barnabé: $O$ intérprete, ele inaugura o instante. Inaugura a coisa. Acontece algo, não é uma repetição. É nesse sentido que eu falo do intérprete. Porque o crooner é a pessoa que repete. Está repetindo o que ouviu, tentando imitar ou fazer. Agora, tem a pessoa que inaugura o negócio, "aqui" está começando alguma coisa.

CB: Acho que isso você vê até nos músicos tocando, a maneira, se eles estão presentes...

Arrigo Barnabé: É. Tem músico que é...

CB: Que é intérprete, tem músico que é crooner.

Arrigo Barnabé: Que é intérprete, tem músico que é crooner. Que é um cara que repete. Que está repetindo.

CB: Não está ali presente mesmo, na hora, não é?

Arrigo Barnabé: Não, está lá, mas não percebe que ele está só repetindo o que foi feito.

CB: Não, digo assim, atento para a situação. Isso é uma coisa bem interessante nos shows com o Itamar, você tinha que ficar muito atento, porque podia acontecer qualquer coisa no show. E esse estado de atenção deixa você aberto para o que vai acontecer, para improvisar, digamos assim, não no sentido jazzístico, mas para improvisar nas intenções.

Arrigo Barnabé: Sim, sim, improvisar. Improvisar no sentido de contar com o acaso, contar com a...

CB: Isso, de estar disponível para ele, responder a...

Arrigo Barnabé: É.

CB: E aí, por exemplo, a Missa que você compôs para o Itamar, eu assisti lá na com a Jazz Sinfônica, e infelizmente não foi um dia legal...

Arrigo Barnabé: Não foi.

CB: Acho que a gravação é melhor.

Arrigo Barnabé: A gravação é bem melhor.

Arrigo Barnabé: Não, é pouco ensaio.

CB: Pouco ensaio. É.

Arrigo Barnabé: A música é muito difícil. Muito difícil. Eles me xingavam muito. Porque eu tinha feito a Missa do Bispo, que era a primeira, que foi mais 
recatada. A do Itamar, eu... Também tem o seguinte, a do Itamar eu trabalhei com uma orquestra maior, aí fica mais complicado. Fica mais complicado para ensaiar. Você vai ensaiar com seis, sete, músicos, é muito mais fácil, do que você ensaiar com sessenta.

CB: E que não é uma, digamos assim, para a Jazz Sinfônica não é uma coisa usual.

Arrigo Barnabé: Não é do repertório deles. Mas o Galindo preparou bem as coisas. Eu acho que pelo...

CB: Tempo que foi, foi bom, não é?

Arrigo Barnabé: Eu acho que pelo tempo que foi, o resultado foi bom... Aí, mesmo no disco deu muito trabalho também, não saiu como eu queria que tivesse saído. Os tempos ficaram muito lentos, tive que acelerar no computador. Teve coisas que eu tive que colocar efeitos eletrônicos, para disfarçar a aceleração das vozes. Então tem uns momentos lá na Missa, você vai escutar, tem efeitos. Efeitos eletrônicos. Ficou legal. A hora que você escuta fica legal, mas não está na partitura.

CB: Entendi.

Arrigo Barnabé: $E$ ali tem um monte de fragmentos que me lembravam o Itamar, de gestos dele...

CB: Eu ia dizer isso, que não conheço tanto a música para perguntar sobre aspectos musicais, mas há momentos em que é claramente identificável: "Ó, o Itamar aí".

Arrigo Barnabé: É, é. Tem mesmo.

CB: Quer dizer, você fez para ele, lógico que ia ter coisas dele. Mas aí era mais como uma...

Arrigo Barnabé: Você quer ver? Deixa eu te mostrar. Eu tenho tanta (incompreensível) do Itamar.

CB: Todas as versões, não é, de...

Arrigo Barnabé: Não, não. Tantos discos. Você quer um?

CB: Ah, eu aceito, se você quiser me dar, eu...

Arrigo Barnabé: Te dou vários. Quantos você quer?

CB: Não precisa vários, um está bom. A não ser que você queira que eu dê para alguém, tal.

Arrigo Barnabé: Eu quero sim. 
CB: Mas então eu acho que é isso. Qualquer coisa, também, te dou uma ligada, está?

Arrigo Barnabé: Você lembra quando veio aqui eu estava com uma letra do Itamar para fazer música, eu estava escrevendo umas frases de baixo você tem isso ainda?

CB: Eu acho que eu tenho.

Arrigo Barnabé: Eu nunca mais vi. Eu não me lembro direito, eu fiquei: "A Clara veio aqui, o que era que a gente ia fazer?"

CB: A gente ia gravar uma música... Não era isso? Quando ele pretendia regravar toda a discografia lá no estúdio da Simone Sou, as coisas, a...

Arrigo Barnabé: Ele queria que fizesse música...para uma letra dele...

CB: Uma música para as Orquídeas, eu não sei se para as Orquídeas.

Arrigo Barnabé: Para as Orquídeas. Falar (incompreensível), dei a letra.

CB: A letra eu não tenho, eu acho. Posso procurar nas minhas coisas lá, mas eu acho que ainda tenho a grade...

Arrigo Barnabé: Eu não consigo fazer...

CB: A grade que você tinha mandado.

Arrigo Barnabé: Sei. Eu não consigo musicar letra pronta

CB: Música para a letra.

Arrigo Barnabé: Musicar letra pronta. Eu tenho muita dificuldade. Assim, achei super legal, porque o Sergio ${ }^{183}$, é uma coisa que ele faz.

CB: Sim.

Arrigo Barnabé: Eu não consigo fazer. Se eu tivesse que fazer uma coisa dessas para mim...

CB: Seria difícil.

Arrigo Barnabé: Seria uma tortura. Eu acho muito difícil.

CB: Isso, acho a gente não comentou, mas só para acabar, deve estar cansado, de falar...

Arrigo Barnabé: Não.

\footnotetext{
${ }^{183}$ Sergio Molina parceiro de música das letras de Itamar Assumpção no projeto Sem pensar nem pensar, de 2009.
} 
CB: É impressionante como a gente vê o Itamar, mesmo com essas coisas todas, não é?

Arrigo Barnabé: Não, mas o Sergio fez um negócio, usando gestos do Itamar e nos arranjos também, as intervenções vocais, ele tem muito gesto do Itamar.

CB: É, tem também o fato de eu ter tocado com o Itamar, então essas linhas...

Arrigo Barnabé: Você tocou. A Miriam já tocou com o Itamar, não é?

CB: É.

Arrigo Barnabé: Quem mais?

CB: Não, mais ninguém. Só nós três, eu, a Miriam e o Sergio, que a gente tocou com ele, trabalhou. Mas é interessante que, por exemplo, no disco do Ataúlfo que o Itamar fez, ele está muito presente como Itamar, mas não obscurece a canção.

Arrigo Barnabé: Não.

CB: É impressionante isso.

Arrigo Barnabé: É demais. É uma releitura. Eu comecei a pensar em fazer Lupicínio lá.

CB: Por causa do...

Arrigo Barnabé: Quando escutei o Ataúlfo. Eu comecei a fazer Lupicínio.

CB: Eu achei super legal, porque tem a ver bastante com você, o Lupicínio, não é?

Arrigo Barnabé: É. O cara vai procurando com quem... Foi quando o Ataúlfo, 1992 ?

CB: 1995.

Arrigo Barnabé: Muito legal, aquele trabalho eu adoro. Isso saiu na Caixa Preta?

CB: Saiu na Caixa Preta. Todos os discos que ele tinha feito. Eles conseguiram juntar tudo, foi um tormento para encontrar todos que participaram, para assinar as autorizações.

Arrigo Barnabé: Nossa Senhora. 
CB: Belo trabalho. Mas enfim, tem uma última questão que é a da forte presença do Itamar. Então por isso aquela coisa que eu falei da música, de como a gente cuida dessa música, sem esse aparato, com a ausência dele.

Arrigo Barnabé: Você tem que pensar no potencial interpretativo que ela oferece.

CB: É. É isso. Se não você estraga a música.

Arrigo Barnabé: É. Se não ela fica...

CB: Banal, não é?

Arrigo Barnabé: É. Eu não vou dizer banal, porque tem algumas coisas que o texto é muito bom e nunca vai ficar banal, o Noite Torta, por exemplo.

CB: Sim. É impressionante.

Arrigo Barnabé: Quer dizer, se a pessoa der um pouco de atenção para o texto, um pouquinho, os caras vão falar: "Mas que interessante isso.", no mínimo.

CB: É.

Arrigo Barnabé: É.

CB: Então muito agradecida. 


\section{c) Conversa com PAULO BARNABÉ}

Clara Bastos: Mas, enfim, estamos aí, não é?

Paulo Barnabé: Sim.

CB: O Arrigo falou muito desse começo aí, antes do Itamar formatar as coisas para ele, de utilizar o baixo, que vocês ficavam muito juntos e pesquisando.

Paulo Barnabé: É.

CB: Eu fiz um monte de pergunta, mas a gente vai papeando aqui.

Paulo Barnabé: Não, esse negócio do baixo, o Itamar tinha aquela coisa intuitiva com o baixo, principalmente naquela época, lá, e ele usava mais o violão para compor.

CB: Fazia acorde, não é?

Paulo Barnabé: Ele compunha no violão. Eu não sei se ele já veio de Arapongas, quando a gente o convidou para morar com a gente, ali na represa, foi uma proposta...

CB: Lá em Guarapiranga?

Paulo Barnabé: É, com uma proposta de a gente fazer a banda. Ele veio para cantar, acho que o baixista era o A.C.Tonelli, eu não lembro muito bem. Eu sei que o Itamar tocava baixo também, ele pegava baixo. Eu acredito que o que influenciou na maneira dele, na concepção dele, ele não veio com aquilo de Arapongas, entendeu? Foi a partir do momento que ele começou a conviver com a gente também, e com as coisas que a gente ouvia aqui em São Paulo. Porque eu acredito que lá em Arapongas, ele tinha um certo limite.

CB: De acesso?

Paulo Barnabé: De acesso e de pessoas que não tinham essa sacação, entendeu? Que a gente tinha.

CB: Ou de buscar mesmo, não é?

Paulo Barnabé: De buscar. Quando ele chegou para conviver com a gente, a gente ouvia doideira, loucura, ele ouvia também. Ele gostava muito Elvis Presley. Ele ouvia muito em Arapongas quando ele era adolescente. Aqui, em São Paulo, a gente começou ouvir Miles Davis. Aí eu mostrei para ele, através de uma menina, a Tânia Celidonio, que veio de Nova York, ela trouxe o disco do Bob Marley, e ela mostrou para mim assim: "Ah, cara, vou mostrar um disco que você vai gostar muito. Um som que eu acho que você vai gostar". Eu ouvi, fiquei chapado, aquelas linhas de baixo.

CB: É maravilhoso você pensar. Se você ouvir qualquer gravação de Bob Marley, mesmo hoje, você fala: "Pôxa, que coisa linda." 
Paulo Barnabé: Porque a linha de baixo, parece que ela atravessa a métrica. Ela começa, atravessa a métrica e conclui em um outro lugar lá, entendeu? É uma concepção legal. Imagina assim, a gente ouvindo isso na década de 70, foi uma grande novidade. Hoje em dia está diluído até.

CB: Sim, sim.

Paulo Barnabé: Mas foi um dado novo. Aí cheguei para o Itamar, falei: "Itamar, cara, você precisa ouvir um cara. Precisa ouvir um cara, que a Tânia trouxe aí, um disco, um disco importado.". Era diferente, a capa era diferente, era tudo mais duro. E como eu e ele, a gente se dedicava muito a fazer audições de disco, a gente sentava e ficava ouvindo detalhadamente tudo.

CB: Ouvindo e falando, ou...

Paulo Barnabé: Absolutamente. Aí algumas coisas ele sacava, a gente voltava, algumas coisas eu sacava. Mas a gente destrinchava assim, entendeu?

CB: É um super estudo, na verdade, não é?

Paulo Barnabé: Fazia um, como se diz na medicina, uma dissecação musical. Dissecava. E a gente tinha muito disso. A gente tinha uma percepção, a gente se dava muito bem fazendo, ouvindo. Um entendia o outro, e a gente tinha 0 mesmo entendimento da loucura. Era igual.

Clara Bastos: A mesma percepção?

Paulo Barnabé: A gente já se olhava, já sabia que você estava sacando, o que ele estava sacando era a mesma coisa. Estava se entendendo. Aí eu trouxe lá - Bob Marley, aí o Itamar começou a ouvir o Bob Marley também. A gente ouvia, ouvia, ouvia, ficou nossa trilha sonora durante muito tempo. E isso, junto com outras coisas, e com a própria "sacação" dele também, que ele tinha, própria, foi que eu acho que ele começou a concepção de linha de baixo dele. Por exemplo, o Tô Tenso. Tô Tenso é uma linha de baixo elaborada assim, é atonal.

CB: Que é a parceria...

Paulo Barnabé: Minha, do Arrigo e do Itamar. O Arrigo, ele tem a (tan-dandan, tum tum), ele tem essa linha melódica aí. O Itamar fez a linha do baixo. Isso daí, ele não tirou de nada, ele tirou dele mesmo, não é porque ele ouviu Miles Davis, nem Bob Marley. Isso aí é uma coisa dele. Então tem umas coisas que são dele, tem umas coisas que são misturadas, que é de influência.

CB: A gente não tem como explicar como que as pessoas criam. Essas coisas, acho que, pelo o que eu conversei com o Arrigo, essa convivência foi muito forte, foi muito importante, não é?

Paulo Barnabé: Importante.

CB: Para todos, não é? 
Paulo Barnabé: Para todos. E eu acredito também que isso foi muito importante, eu acho que foi decisivo assim, para o Itamar e para mim também. Porque a minha postura em estúdio, em ensaio, era a mesma postura do Itamar. Porque a gente ensaiava muito junto. A gente ficava assim, tocando bateria, baixo, aí eu ia para o baixo, o Itamar ia para a bateria, aí pegava a guitarra, ficava fazendo isso direto, mas direto, direto. Com a música do Arrigo, quando nós fomos incumbidos de fazer o arranjo do...

CB: De base, não é?

Paulo Barnabé: Diversões Eletrônicas e Infortúnio. A gente já não estava mais morando junto, lá na represa. O Itamar estava num lugar, estava no Bexiga, numa casa do Rubão (Sabino) ali, eu acho, estava hospedado lá. Eu estava não sei onde, estava num amigo, eu não sei. Ah, estava na Tânia Selidonio, essa minha amiga que...

CB: Que te mostrou...o Bob Marley.

Paulo Barnabé: Mostrou o Bob Marley. Morava uma turminha, era uma república. Aí a gente se encontrava na casa do Arrigo, que era lá na Avenida Corifeu de Azevedo Marques, que ele morava junto com o Mario Lucio. E no quartinho lá, na sala tinha um piano, tinha uma bateria, tinha um baixo com amplificador. Ficava eu e Itamar lá, ou num quartinho, no quartinho do fundo. A gente ficava no quartinho do fundo. A gente já ficava direto e não queria incomodar os outros, a gente foi para o quartinho, mas sem acústica, sem nada.

Clara Bastos: Só para...

Paulo Barnabé: E a gente ficava pegando a música do Arrigo. A gente já sabia o que era o dedecafonismo, o Arrigo explicou a série, ele deu uma aula para mim. Ele foi explicando, foi falando, quase compondo no sistema de doze.

CB: É porque ele falou que fazia mesmo sem saber. Ele não sabia que tinha uma regra.

Paulo Barnabé: Quem, o Itamar?

CB: Não, o Arrigo. Depois que ele foi saber isso. O Arrigo falou assim, que ele um pouco, porque ele escutava assim, mas ele não sabia exatamente que tinha umas regras, ele ficava tentando achar por conta própria. Depois, acho que, aí na USP, lá ele...

Paulo Barnabé: É, ele pegou. Na USP, ele pegou lá do Centro de Composição . Ele falou que estava compondo tal, mostrou o que estava fazendo. O Itamar estava convivendo com a gente nessa época. Aí eu acho que o Itamar não queria muito entender profundamente, entendeu? Ele é intuitivo do jeito dele: "Ah, tá bom, tá bom". Pegou a frase (cantarola), ele era muito dedicado. Ele era muito... Aí a gente começou a fazer aquele arranjo, da abertura do Infortúnio. Depois do cânone de metais entra o piano, entra (cantarola) daí, essa quebrada. Que a gente fez em cima... é um pensar intuitivo em cima de uma coisa rigorosa, dodecafonismo. Mas também, é lógico, sacando a própria estrutura do dodecafonismo também, porque você tem que ser muito bom para 
poder interferir dessa maneira, nessa linha que o Arrigo compõe, entendeu? Que é tudo quebrado, não é 4 por 4, é tudo misto, compasso misto. E aí quando a gente fez o arranjo da música inteira, a condução, a linha de baixo, a bateria, os arranjos. Que outra música que a gente fez? Fez Infortúnio...

CB: E o Diversões?

Paulo Barnabé: E Diversões também. O Diversões, eu me lembro que Itamar, que eu conversava muito com Itamar com esse negócio de John Travolta, Embalo de Sábado à Noite, tinha (tunga tunga tunga...)

CB: Aqueles baixos em oitavas, coisa de Disco, não é?

Paulo Barnabé: É. Aí falou assim: "Vamos usar isso."

CB: Que engraçado.

Paulo Barnabé: Eu faria um (chac chac chac - imitando o chimbau) uma coisa meio Disco, para inserir no Diversões.

CB: Eu jamais imaginaria que a inspiração era essa! Já que o efeito é totalmente outro.

Paulo Barnabé: Então era uma coisa meio de massa. E o tema Diversões Eletrônicas era diversões eletrônicas, que era uma coisa de massa também, que todo mundo fica jogando fliperama, era a maior onda. Eu dei essa ideia de fazer em cima do John Travolta. Aí Itamar pegou a linha de baixo (ton, ton toron, to toran, tan, to), aí ele fez assim (ton, teron, toron, toré, tori tori ton), entendeu? Então começou a mudar a linha do baixo, fazendo aquela levada de Disco, pausas, entrando na cabeça, parando, dando pausa, entrando em alguns momentos da nota dodecafônica lá do...

CB: Sim, da série.

Paulo Barnabé: Da série. A gente estudava, e tinha que estudar. É meio intuitiva, mas a gente sabia que tinha: "Não, aqui não. Não fica bom. Não faz aqui. Vai, vai de novo." "Não, vamos tentar colocar a nota ali, o apoio ali, dar acentuação ali". la construindo, entendeu?

CB: É, porque na verdade, isso dá uma musicalidade forte para a música, você ouve, não parece uma coisa cerebral. Que você ouve, e fica uma coisa bem...

Paulo Barnabé: Suingada.

CB: Suingada e orgânica, não é?

Paulo Barnabé: Exatamente, sacou tudo. É isso daí mesmo. A nossa...

CB: Quer dizer, a função de vocês era levar para humano, não é? 
Paulo Barnabé: O nosso negócio era levar para o suingue da coisa. O Arrigo era mais duro. Entendeu?

CB: Não, ele mesmo fala: "O assunto dele não é comigo".

Paulo Barnabé: É, era mais duro. E quando eu pegava com o Itamar a coisa do Arrigo, a gente suingava.

CB: Arredondava.

Paulo Barnabé: É, fazia aquele grande suingue, entendeu? Ficava com a cara meio de rock, meio não sei o quê, meio black.

CB: Legal. Você também chegou a tocar com o ltamar, não é?

Paulo Barnabé: Toquei mais de 1 ano.

CB: Quero dizer, tocando como trabalho...

Paulo Barnabé: Na Isca.

CB: É, na Banda Isca de Polícia.

Paulo Barnabé: Eu gravei, eu peguei toda a fase de preparação, antes do disco, que tudo que o Itamar fazia, ele mostrava pra mim: " $O$, vê isso daqui, vê essa música."

CB: Tinha cumplicidade, não é?

Paulo Barnabé: Essa época, a gente morava na Represa ainda, o Itamar me apresentou algumas músicas. Aí, eu me lembro aquela música lá (dum dem, dum dem), sabe? Eu fiz uma linha de bateria meio louca lá. O Itamar adorou. Então eu me lembro que ele conseguiu o estúdio do Rogério Duprat, para poder gravar duas músicas, três. Aí entrou no estúdio, eu e Itamar, mais ninguém, só. Porque a gente estava muito acostumado a pegar vários instrumentos e tocar. Então eu pegava a bateria, às vezes eu pegava o baixo, ele pegava a bateria, eu pegava a guitarra.

CB: Isso é bem interessante, que você vê o Itamar fazendo, quer dizer, eu não sabia de onde vinha essa vivência. Vem disso, desse momento aí.

Paulo Barnabé: Vem desse momento nosso.

CB: De ficar se divertindo.

Paulo Barnabé: Isso aí é coisas que a gente passou durante 2 anos, fazendo... Aí a gente entrou no estúdio do Rogério Duprat, só nós e maisninguém. Aí começamos... que a gente tinha uma metodologia, cara, a gente era meio rigoroso. Aí a gente montou a linha, ficamos juntos, a linha da bateria e tocando baixo juntos, (dum dum, dum dum, Tum, da da. Tum, da, tum da). Era uma linha meio torta assim, parecia que ia sair fora, mas voltava. E em cima dessa linha de baixo. Aí a gente fez toda a gravação, aí depois, eu coloquei o piano em cima, um piano de calda lá... bom

CB: No estúdio? 
Paulo Barnabé: No Duprat. O Itamar colocou a guitarra, montamos a música, Itamar cantou, eu acho que eu fiz um back. O Itamar não tem essa fita. Depois a gente gravou uma outra, gravamos duas ou três. Aí o Itamar chegou para mim um dia, ele falou assim: "Cara, eu fui pegar lá, a fita, que a gente mixou e tal, e eu conversei com o Duprat. O Duprat falou que é muito boa, está muito bom o arranjo do (bóm bóm...)", como que é mesmo o nome dessa música, cara? Como que é o nome dessa música ${ }^{184}$ ?

CB: Que é da Isca?

Paulo Barnabé: É da Isca, que é do primeiro disco dele. "Baby, não se assuste..." "Cara, está muito bom, ele gostou muito da linha da bateria e do baixo, não sei o quê", estava bem entusiasmado. O Rogério, ele achou que ele tinha... que a gente foi construído uma coisa meio nova ali. Então eu acho que ele (Itamar) começou meio a pirar mesmo, assim, de todo esse convívio, essa "sacação", essas audições, essas coisas da gente pegar e começou a fazer uns negócios loucos. Aí o que aconteceu foi o seguinte, a gente não estava mais morando juntos, mas a gente se encontrava direto em estúdio para ensaiar. Eu me lembro que eu participei do show do Jorge Mautner, do Jacobina, no Sesc Consolação. Fazia todas essas coisinhas, ia lá, fazia com ele. Antes, ele não era conhecido, não era nada, o Itamar. Não era nada, absolutamente de ninguém. A gente fez com o Jacobina, Jorge Mautner, fez algumas coisinhas e tal. Aí depois, a gente começou a preparar o disco, o repertório do disco, ele mostrava para mim, ele chegava com o violãozinho, tocava, ele fazia linha de baixo, ele fazia no piano. A gente tocava muito, aqui, também, tinha um piano. Aí ele começou a fazer o repertório do disco, aí ele montou uma banda, Isca de Polícia, que era o Luis no piano, Luis Lopes...

CB: Ah, com piano. Que legal.

Paulo Barnabé: Kiko, o Kiko que era do cabelo meio rastafari, assim, ele era de uma banda...

CB: Acho que não cheguei a conhecer.

Paulo Barnabé: Uma banda lá do nordeste até. É aqui de São Paulo, eu vou lembrar o nome da banda. Aí tinha eu fazendo a batera, o Jean Trad na guitarra, o Cezinha na percussão, parece, eu não me lembro.

CB: Hum-hum. Até que era bastante gente.

Paulo Barnabé: É. Mas não tinha metaleira, não tinha nada. Talvez uma coisa que eu acho que devia ter no som do Itamar era metal, o que faltava.

CB: Normalmente, não é?

Paulo Barnabé: É, não sei.

CB: Ou constantemente?

\footnotetext{
${ }^{184}$ Canção Baby do CD Beleléu.
} 
Paulo Barnabé: É, pode ser. É que tinha muita frase melódica...

Clara Bastos: É, muita ideia de melodia.

Paulo Barnabé: É, o baixo né?.

CB: Porque aí, às vezes, fica muito embolado, não é?

Paulo Barnabé: De repente, poderia ter, sei lá, mas tudo bem. Tinha um piano lá também. Aí a gente ensaiava muito, muito, ensaiava demais. Ensaiava exaustivamente. Aí a gente resolveu ir para o estúdio, começamos a gravar tudo, linha por linha, baixo, bateria, tudo. À vontade.

CB: Isso em outro lugar?

Paulo Barnabé: Depois foi em outro estúdio que a gente gravou, não me lembro o nome do estúdio, mas tem o disco lá. Aí a gente fez tudo, aí teve o lançamento e show, show. Muito show.

CB: Aí que começou a coisa?

Paulo Barnabé: Aí chegou uma hora que eu estava querendo fazer meu trabalho, nisso entrou... eu dei um toque para colocar, o Pamps estava tocando baixo ainda aí, ele saiu e...eu chamei o Skowa para trocar.

CB: Daí eu acho que o Skowa ficou, aí depois entrou o Paulinho Lepetit?

Paulo Barnabé: O Skowa ficou um tempo, aí entrou outro baixista, quem que era?

CB: Não era o Paulinho Lepetit?

Paulo Barnabé: Não era o Paulinho, eu não cheguei a trabalhar com o Paulinho. Não sei isso foi já com o Skowa ou entrou outro baixista, não me lembro.

CB: Tá. Quer dizer que não firmou muito, a coisa do baixo ficou meio instável, não é?

Paulo Barnabé: É. Aí eu sei que nisso foi uma temporada com ele no Lira ${ }^{185}$, várias, fiz festival de lacanga. Sei lá, fiz algumas coisas com ele aí eu saí.

CB: Sim, para fazer tuas coisas, não é? Claro, normal.

Paulo Barnabé: Fazer minhas coisas, saí do Arrigo, saí do Itamar também. Mas eu fiquei com ele mais 1 ano, uns 2 anos tocando na banda Isca. Um ano e pouco.

CB: Tocando. Um pouco consequência também desse trabalho aí, como se tivesse que materializar aquilo que vocês fizeram juntos, não é?

Paulo Barnabé: É.

${ }^{185}$ Teatro Lira Paulistana. 
CB: De um certo jeito assim.

Paulo Barnabé: Mas o Itamar, depois que a gente separou ali da Represa, a gente tinha esses encontros, continuava se encontrando, fazendo os arranjos do Arrigo. Mas o trabalho dele, do disco dele, estava isolado lá, fazendo.

CB: Sozinho. Entendi.

Paulo Barnabé: Lá na casa lá, dele já. Ele mostrava para mim, ficava mostrando, ele vinha mostrar. A primeira pessoa que ele queria mostrar era para mim. Se eu gostasse, estava tudo bem, ele já ficava contente (risos). Porque ele não tinha ninguém, entendeu.

CB: Referência, não é? Não tinha referência.

Paulo Barnabé: É. Ele ia mostrar para quem? Como a gente era muito próximo, então...

Clara Bastos: É isso que ele falava um pouco, essa coisa... Acho que ele sempre precisou dessa confirmação. Acho que como qualquer pessoa, não é? A gente nunca sabe se a gente é bom, a gente precisa estar confirmando sempre. Isso percorreu esse tempo, a...

Paulo Barnabé: E por isso que o Paulo Lepetit também não fez mais coisa, relacionamento. Porque aí...

CB: Acho que aí tudo bem, eles também faziam isso, mas aí já estava mais como uma escola mesmo, como se ele já tivesse...

Paulo Barnabé: Ele já tinha aquela linha, já.

CB: E então ele tinha que ensinar a linguagem. Por exemplo, eu peguei essa coisa...

Paulo Barnabé: De ele passar, não é?

CB: De ele passar aquelas coisas que ele sabia.

Paulo Barnabé: Isso daí era uma coisa que a gente fazia. E tanto é que eu fiz isso durante muito tempo na Patif Band, igualzinho. Se você chegasse no estúdio e visse o Itamar e visse eu, você ia achar a mesma coisa. "Não, não, não sei que lá, pega, não sei que lá". Aí pegava o baixo do cara, ficava tocando, mostrava, o cara ficava tocando...

CB: Aliás, é muito legal, na verdade, isso é uma coisa muito importante.

Paulo Barnabé: Até que eu parei, e comecei a escrever.

CB: Isso, na verdade, é uma coisa muito legal, porque você não tem uma coisa assim, é o certo. Tem que aprender uma linguagem que a gente tem que fazer aqui. Não adianta você vir com uma coisa... Depois você coloca essas coisas, mas ter uma coisa que vai garantir que aquilo seja entendido como uma linguagem. Você não pode ferir aquilo, de certo jeito. Então daí quando o cara 
começa a ficar com mais ideia, a tendência natural é sair ou fazer outras coisas.

Paulo Barnabé: Depois ele achou um negócio lá, uma linha, também, muito louca lá, ele se firmou naquilo. Eu acho que foi só mais para frente que ele se libertou um pouco, que começou a fazer umas canções, fazer uma coisa mais popular. Ele deixou aquelas linhas de baixo, aquelas coisas, começou a fazer umas coisas populares.

CB: Talvez não precisasse muito, acho que ele queria se afirmar um pouco como...

Paulo Barnabé: Gravou Ataúlfo Alves, fez aquela música: "Você vai notar, olhando ao redor..."

CB : Mal menor

Paulo Barnabé: As canções lindas, todas.

CB: Poema também. Conheceu a Alice, o Paulo Leninski, então ficou mais...

Paulo Barnabé: Isso. Tudo isso daí já é uma outra fase do Itamar.

CB: De qualquer jeito já está um pouco presente, mesmo desde o começo, não é?

Paulo Barnabé: Também estava. Estava. Porque eu me lembro que a gente comentava da poesia do Leninski na época. Eu já tinha feito Acapulco drive-in , a letra. Eu convivia com Itamar na época. Lady manicure, a letra, fiz a letra e a música também. Então a gente comentava muito dessa coisa de história em quadrinhos, com o Itamar. Isso foi um negócio que o Itamar entrou em contato através da gente, esse tipo de...

CB: De linguagem...

Paulo Barnabé: Leitura, de letra.

CB: E da coisa do show também, visual, que às vezes a...

Paulo Barnabé: Do visual também. Também.

CB: Porque ele tinha a coisa do ator, mas assim, você além de ter a coisa do quadrinho mesmo, não é?

Paulo Barnabé: É. Então eu acho que isso daí são as coisas...

CB: Uma coisa meio urbana?

Paulo Barnabé: Urbano, exatamente. Que ele pegou a intuição dele, a convivência com a gente, intuição. Ele foi moldando, foi... esse papo de poetas, Leminski, outros poetas também, que às vezes ele não tinha acesso lá em Arapongas, a gente mostrava, lia, fazia sessões de leituras, comentava não sei o quê, muita história em quadrinhos, lia, tinha bastante coisa. Era uma 
convivência assim, bem... Fotografia, alguns caras que tocavam, era o Tonelli, ele revelava, tirava foto. Então o Itamar era um cara muito inteligente, ele sacava o que a gente conversava. Ele entrou de cabeça e começou a inventar junto, como a gente estava inventando também. Ele começou a participar dessa invenção nova que a gente estava descobrindo também, através do atonalismo, do dodecofanismo, ele entrou. E tanto é que...

CB: Isso era música popular, não é?

Paulo Barnabé: Na música dele, ele tem alguma coisa bem de atonalismo também, ou de dissonância, eu não sei.

CB: É, até têm coisas que são...

Paulo Barnabé: As linhas de baixo.

CB: Acho que tudo, harmonicamente, é muito simples. Então ele pensa, acho que, mais em contraponto...

Paulo Barnabé: Mais no contraponto e das linhas...

CB: E com uns choques harmônicos de estar cantando terça maior, é acontecer terça menor no acorde. Mas tudo bem, a música é assim.

Paulo Barnabé: Enfim, aí depois, eu sei que ele, quando ele formou a segunda formação, já... Já era outra linha, outro papo, outra história, já estava fazendo o negócio dele, tal. Eu já deixei, parei de conviver, fiquei na minha, fui fazer meu som.

CB: Claro, fazer suas coisas, fazer seu som.

Paulo Barnabé: De vez em quando a gente se trombava tal, mas era bem raro. Foi difícil encontrar com o ltamar.

CB: A vida mesmo vai levando...

Paulo Barnabé: É. Eu também tinha muitos compromissos, show. Morava longe. Eu morava em Pinheiros, o ele morava no Brás, não é?

CB: Na Penha.

Paulo Barnabé: Na Penha, é. Cheguei a ir lá algumas vezes, poucas vezes.

CB: Na casa de sempre, de esquina.

Paulo Barnabé: É, de murinho baixo, de esquina, não é? Perto do metrô, aquela decidona...

CB: Eu acho que é isso Paulinho.

Paulo Barnabé: A história é essa. Tem mais coisa aí, mas está bom. 


\section{d) Conversa com PAULO LEPETIT}

Clara Bastos: Para a gente, Paulo, o lance é a música, independente das vivências que foram intensas com o Itamar, e tudo...

Paulo Lepetit: É.

CB: Para mim, por exemplo, o jeito de tocar e minha relação com a música, têm muito a ver com ele. Não tem como não pensar no Itamar, sempre que eu vou fazer som.

Paulo Lepetit: Sim.

CB: Eu acho que no seu caso, também, né?

Paulo Lepetit: É. Também. Claro.

CB: Eu quero investigar a composição. Porque daqui a pouco, pode ser que o acesso a essas informações se torne mais difícil, na medida em que as pessoas não estejam mais presentes para falar sobre. "Para que vai estudar no meio acadêmico, uma coisa dessas?" Porque é uma fonte de conhecimento.

Paulo Lepetit: Sim.

CB: Como foi sua relação com o instrumento contrabaixo? Porque você também já estudava violão (aproveitemos a tua vivência, a tua experiência, para falar sobre uma área de conhecimento, que é a música). Daí, quando você conheceu o Itamar, você começou a tocar baixo?

Paulo Lepetit: Não. Eu comecei a aprender... Meu instrumento, primeiro, foi o violão. Não sei se você conheceu o Pini?

CB: Não. Eu não conheci... Eu já escutei um pouco dessa história. Daí...

Paulo Lepetit: Que foi o cara que me ensinou. Era a turma da rua, a gente morava na rua Cristiano Viana, era eu, o Luisinho Waack, o meu irmão. Na verdade, o meu irmão foi quem descobriu...

CB: Um cara que tocava...

Paulo Lepetit: É. Aí, ele começou a frequentar as aulas, e o resto começou a ir atrás. Então, eu fui assim, meio... Não tinha assim, um interesse...

CB: Não era afim, necessariamente?

Paulo Lepetit: Não tinha interesse pela música. Nunca tinha tido. E aí, começamos a ter essas aulas lá. E esse professor, ele era muito aglutinador. Ele dava aulas individuais, mas aí...

CB: Chamava as pessoas...

Paulo Lepetit: É. Reunia as pessoas... 
CB: É. Porque às vezes, as pessoas começam a aprender, ficam tocando sozinhas e não sabem como é tocar em grupo...

Paulo Lepetit: É. Exato. Então o meu aprendizado já começou muito prático. Porque daí, a gente ficava tocando junto, e eu sempre já indo, "caindo", não sei por que, para as cordas mais graves...

CB: Graves.

Paulo Lepetit: Já tendendo para o baixo. E ele não era casado, mas tinha uma filha com uma cantora, Irene Portela, uma maranhense e que morava lá, no mesmo...

CB: Na mesma região?

Paulo Lepetit: Na mesma região ali. E a gente começou a desenvolver uma coisa junto, assim... Ela já era compositora, e eu aprendendo a tocar. Mas já fomos aprendendo a tocar, e já tocando.

CB: E fazendo. Claro!

Paulo Lepetit: Então, daí que eu fui me interessar, realmente, pelo baixo, e comprei um baixo nacional, walk pick, que era cópia do Rickenbacker.

CB: Até que não eram ruins, os instrumentos dessa época.

Paulo Lepetit: Não. Eram bons.

Paulo Lepetit: É. Eu tinha, por influência do Chris Squire ${ }^{186}$ que pertencia a um dos primeiros grupos que eu vi...

CB: Sim. Você ficou impressionado...

Paulo Lepetit: Eu fiquei impressionado, assim: "Pôxa, isso é baixo? Isso é que é baixo?". Então, comprei esse primeiro baixo, e começamos a tocar. Depois, tocando com ela, comecei a prestar mais atenção, ia ver... o Lira Paulistana, que tinha acabado de surgir, e eu comecei a frequentar ali. Eu morava muito perto. E numa dessas aí eu vi o Itamar lá, porque o... Gigante ${ }^{187}$, ne verdade, atraído...

CB: Pelo Gigante.

Paulo Lepetit: Pelo Gigante. Que começou a tocar com o Itamar, e eu fui lá, fiquei impressionado com aquele som. Falei: "pôxa, isso aí, eu..."

CB: Isso aí eu gostaria de fazer.

Paulo Lepetit: É. Eu gostaria fazer. E passou muito pouco tempo. Quer dizer, eu já tinha feito outras coisas também. Com a Eliane Estevão, uma outra cantora também, que era dessa área aí. E teve uma gravação, eu fiz uma

\footnotetext{
${ }^{186}$ Contrabaixista do grupo inglês YES.

${ }^{187}$ Gigante Brasyl, baterista.
} 
gravação no disco dela, que ficou muito bacana. Era uma música desse Pini. E o Gigante chegou a mostrar para o Itamar. E tinha um trabalho de baixo bacana. Acho que foi minha primeira gravação assim, e já era um baixo desenhado, assim, essa coisa de...

CB: De conversa, não é?

Paulo Lepetit: É.

CB: Assim, de...

Paulo Lepetit: De não ser aquela coisa de bumbo e baixo.

CB: Quer dizer, quem tocou com o Itamar, já tinha uma tendência a não fazer só isso.

Paulo Lepetit: Sim. Já vinha para ter uma afinidade com aquilo. Quer dizer, já tinha essa... Então, percebi que era a mesma área.

CB: A mesma linguagem, ou próxima.

Paulo Lepetit: Eu já tinha uma tendência para esse lado, de um baixo mais desenvolvido. E o Itamar ouviu isso e gostou. Curtiu.

CB: Curtiu. Ficou legal.

Paulo Lepetit: Então, conheci, em seguida, o baixista que tocava com ele, na época era o Eskova... Tiveram vários, uma sequência assim. O Eskova saiu depois de Águas Claras, acho.

CB: Sim. O Festival de Águas Claras.

Paulo Lepetit: De Águas Claras. E aí, o Itamar me convidou. E aí, a gente teve essa...... quer dizer, eu fui o último dos...

CB: Dos que entrou.

Paulo Lepetit: Que entrou. Eu fiquei com a vaga, ali. E a gente teve assim, uma empatia muito grande, logo de início. Tanto é que das primeiras conversas que a gente teve... Que a gente já ficou, não só a coisa musical, a gente ficou amigo, assim, de...

CB: O Itamar tinha essa coisa, de...

Paulo Lepetit: Tinha, é.

CB: Se ia tocar com ele, tinha que se relacionar.

Paulo Lepetit: É, de ser amigo. Ter relacionamento...

CB: Isso é até uma coisa que às vezes atrapalhava dependendo do caso... Os músicos profissionais, digamos assim, entre aspas, não queriam saber senão qual era o cachê...

Paulo Lepetit: Não. Mas ali era natural, porque a gente ensaiava todo dia. 
CB: É.

Paulo Lepetit: Ensaiava... Tendo show ou não. E geralmente, não tinha show. Era um show aqui, outro lá. Que ele recusava muita coisa. E a gente então, ensaiava, geralmente, à tarde, aí, depois, ia jogar bola. Pelo menos umas três vezes por semana, a gente ia...

CB: Nossa, que delícia.

Paulo Lepetit: É. Tem um amigo meu que tinha um sítio em Itapecerica da Serra, então a gente acabava o ensaio, dava uns telefonemas para juntar...

CB: A galera. Não era nem para dar satisfação, era para juntar a galera.

Paulo Lepetit: Para juntar. É. A galera. Para tentar juntar sete pessoas com dois carros, porque lá, no sítio, já tinha um. O caseiro que morava lá. Então, a gente precisava de sete. Sete. E aí, geralmente, a gente conseguia reunir isso, e ia jogar. $E$, depois, continuava à noite. Nessa época, eu tinha carro, e às vezes, estava de moto. Então acabava sobrando para mim levar o Itamar até a Penha. Eu fui à Penha 550 vezes (risos).

CB: Milhões de vezes. Se fechar o olho, até vai sozinho.

Paulo Lepetit: la. la. Sozinho.

CB: O teu jeito de tocar mudou, ou ele só se confluiu com a maneira do Itamar? Você acha que ele se transformou bastante, depois de tê-lo conhecido?

Paulo Lepetit: Com certeza, porque, quando eu comecei a tocar com ele, eu era intérprete das linhas de baixo. Ele já tinha todas as frases. Ele compunha.

CB: Você era intérprete da frase de outra pessoa?

Paulo Lepetit: É. Para fazer esse trabalho. Em outros não.

CB: Claro, claro.

Paulo Lepetit: Embora tivesse essa confluência de estilo, eu precisei primeiro, entender aquilo.

CB: Acredito que com todo mundo. Com todos os músicos. Podemos notar mais isso no baixo, ele é muito forte na música dele. Porque era assim, muitas vezes, que ele compunha. Só baixo e voz.

Paulo Lepetit: É a maioria...

CB: A maioria das músicas.

Paulo Lepetit: Nessa época, nessa época, ele compunha, sim.

CB: Com baixo e voz?

Paulo Lepetit: Com baixo, voz, e aí...

CB: Depois ia ver que harmonia que estava implícita... 
Paulo Lepetit: É. Geralmente, as harmonias eram muito simples. Dois acordes. Quatro acordes, no máximo. Sempre. Isso durante...

CB: A música inteira.

Paulo Lepetit: E durante todas as fases dele. Mas nessa época, ele já chegava com isso. Eu tive que aprender essa linguagem. E a gente, quando não tinha o futebol, eu e ele, depois dos ensaios, a gente ficava sempre junto, na casa de um, na casa de outro. Tinha a casa da Caia e da irmã dela, que moravam ali em Pinheiros, e o Itamar tinha a chave...

CB: Da casa.

Paulo Lepetit: Da casa, e um quartinho de empregada lá, onde ele...

CB: Podia ficar se quisesse.

Paulo Lepetit: Então a gente ia, praticamente, todos os dias para lá, e ficava estudando...

CB: Bastante.

Paulo Lepetit: O dia inteiro estudando. E tocando. Preparando as músicas novas que ele vinha fazendo. Então aí começou um bate-bola, já.

CB: Sim. Já não era mais só ter que se inteirar da linguagem.

Paulo Lepetit: É. Na formação do primeiro show, que era do disco Beleléu, já estava tudo lá, formatado. Então eu entrei ali, justamente, interpretando aquilo, e raramente conseguia botar uma notinha ou uma frase.

CB: Eu acho que ele é muito mais rigoroso também, no começo, não é?

Paulo Lepetit: Muito rigoroso. É. É.

CB: Depois, assim, de uma carreira estabelecida, digamos...

Paulo Lepetit: Depois de uma confiança estabelecida.

CB: É. Porque, eventualmente, a pessoa mais jovem pode querer chegar para mostrar serviço, e aí começar a tocar de uma maneira que não seja pertinente.

Paulo Lepetit: É. Primeiro, que era uma coisa que era completamente nova, então tinha que entender aquilo, como funcionava. Aí nesse bate-bola que a gente começou a tocar violão muitas tardes. Primeiro, na casa do Rondó, que já estava na banda. Depois o Rondó saiu, aí a gente foi para a casa da Marta, aí passou a ser na minha casa. Quando eu casei passou a ser na minha casa. Mas começou a criar esse hábito de estar sempre tocando, e aí começamos a desenvolver as coisas.

CB: Desenvolver na prática. Acho que o processo criativo desenvolver na prática. 
Paulo Lepetit: É. Exatamente. Eu fui começando a colocar uma frase aqui, outra ali, fazendo sugestões de arranjo. Quer dizer, foi uma coisa desenvolvida, e durante esse tempo todo, eu fui ganhando espaço.

CB: Claro.

Paulo Lepetit: E confiança. Então isso até foi mudando a forma dele compor depois. Ele parou praticamente, de compor, no baixo. Ele passou a me mostrar as músicas... e às vezes tinha sugestão de uma frase, mas aí, eu já punha uma outra frase. Então foi um desenvolvimento junto, que de intérprete, eu fui...

CB: Passando a compositor, digamos assim, ou arranjador. Compositor não. Arranjador.

Paulo Lepetit: Primeiro um intérprete, depois um músico com autonomia, depois arranjador de base, depois fiz arranjos de metais também, sempre junto com o Bocato, ou com o Bino, e até virar produtor.

CB: Até produzir.

Paulo Lepetit: Até produzir.

CB: É legal essa trajetória.

Paulo Lepetit: Uma escola.

CB: Uma trajetória.

Paulo Lepetit: E onde eu fui absorvendo a linguagem dele e fazendo uma...

CB: Porque no fim, tanto faz quem é o autor daquela coisa. Se o resultado estético vai chegar num lugar...

Paulo Lepetit: Exato.

CB: Você vai ter as suas boas ideias. Vai se divertir realizando-as.

Paulo Lepetit: $E$ tem coisas, hoje em dia, não sei se fui eu, ou se foi ele quem fez. A coisa acabou se confundindo principalmente para o trabalho dele. Essa linguagem também me influencia em outras áreas.

CB: Nas suas composições, evidente.

Paulo Lepetit: Em composições, em arranjos, produções de outros discos. Teve uma coisa engraçada, eu fiz o disco da Luísa Maita, que ficou bem diferente. Então, lá na última música que eu arranjei, eu disse: "Agora eu vou dar uma Itamareada", o que no resto não tinha. $E$ aí, as pessoas: "Ah, isso parece Itamar..." Você entendeu? Você usa...

Clara Bastos: Puxa tocando com ele há "40" anos.

Paulo Lepetit: É.

Clara Bastos: Na veia, não tem como. Trinta e poucos anos de vida... 
Paulo Lepetit: Eu comecei a te contar, depois, desviou o assunto, mas uma das primeiras coisas que ele me falou, seis meses depois da gente se conhecer, foi: "a gente pode tocar junto a vida toda." Eu tinha 22 anos assim, falei: "pôxa, não é muito tempo, a vida toda?" E aconteceu. A gente tocou. A gente parou. Voltou. Ele morreu, eu continuei fazendo...

CB: Você não estava tocando junto, porque vieram as Orquídeas, depois eu fiquei tocando com ele, mas de qualquer jeito, você esteve com ele a vida toda, porque estava produzindo as coisas. Estava em uma outra...

Paulo Lepetit: Demos algumas paradas. Mas a gente sempre acabava voltando a fazer coisas junto...

CB: É, de produzir.

Paulo Lepetit: É. Ele morreu, e continuamos trabalhando juntos.

CB: É. Ainda tem um monte de coisa, assim...

Paulo Lepetit: Temos o inédito agora. Continuamos tocando a Banda Isca, fazendo o trabalho. Então quer dizer, ele estava certo nisso.

CB: É uma coisa para a vida toda. É.

Paulo Lepetit: A outra que ele me falou, que ele falou: "eu vou ser que nem Cartola. Só vou fazer sucesso..."

CB: Depois que morrer.

Paulo Lepetit: Depois que morrer. E batalhou por isso. Cada vez que o sucesso chegava perto, ele...

CB: Ele dava uma afastada.

Paulo Lepetit: Dava uma afastada.

CB: Isso eu lembro também. Assim pessoas falam assim: "Mas por que você não aceitou isso? Não. E ia para o outro lado. Fugindo da assim...

Paulo Lepetit: Fugindo da coisa. "Não, eu não morri ainda. Não posso fazer sucesso."

CB: Mas talvez para se preservar... Outra questão é a da performance. Para mim, é uma coisa muito marcante. O Itamar no palco. Quando tocava com ele eu o seguia em todos os sentidos. Musicalmente, escutando e também olhando a figura dele. Para mim, aquilo era uma coisa astronômica. No final do show eu nem sabia o que havia tocado. Como se tivesse "baixado" um santo lá. Então, vejo que era muito forte essa parte cênica, do ator, e que acho que isso irradiava para os músicos. O fato de estar no palco, de ter presença de palco, eu acho que cada um tem seu jeito ali, mas assim...

Paulo Lepetit: O carisma dele era muito grande. E claro, instigava as outras pessoas atrás.

CB: É. Não dava para você ficar lá, desatento, olhando pra qualquer lado... 
Paulo Lepetit: Embora ele não gostasse que fizesse muita coisa. Então, por exemplo, o Gigante que ficava fazendo careta...

Paulo Lepetit: E ele não vendo. (risos) Teve uma vez, num show na Funarte que foi gravado. Daí o Itamar viu: "Mas o que que é isso, não pode..." (risos) Que às vezes, a plateia ria de alguma coisa, ele não sabia o que que era...

CB: É. Era alguém fazendo micagem atrás.

Paulo Lepetit: Era o Gigante lá, batendo na parede, e fazendo... Aí ele coibia um pouco isso. Mas quer dizer, todo mundo tinha uma postura diferente, tocando com ele do que tocando com outro.

CB: É. Porque era muita concentração, no bom sentido.

Paulo Lepetit: Sim, sim. Não era simplesmente tocar as músicas, entendeu? Ele interpretava as músicas mesmo. No palco, ele tinha que passar aquele personagem que cada música tinha. Fazer entender o que está dizendo a música, através, não só dos instrumentos, da letra, mas da performance. Isso era muito forte. Eu me lembro, até, de participações dele, uma vez, eu vi uma participação dele em um show da Zélia Duncan, ele fez uma, duas músicas com ela, e depois, ele não quis sair do palco. Ele ficou no canto, assim, agachado assim. Sem fazer nada. Mas aquela...

CB: A gente estava falando disso aí, da...

Paulo Lepetit: Do carisma dele.

CB: É. Do carisma dele no palco. E aí...

Paulo Lepetit: Ah, então, eu estava falando da...

CB: Contando a história. Ah, sim, sentado no cantinho, no show da Zélia.

Paulo Lepetit: Que ele estava no canto. Ele ficou algumas músicas assim, no canto, sem fazer nada. E quem está na plateia não...

CB: Não conseguia...

Paulo Lepetit: Não conseguia prestar atenção na Zélia. Ficava olhando: "O que que ele está fazendo?" Era uma figura que chamava os olhares. Então era uma coisa muito forte dele. Onde ele entrava, não só no palco, não precisava ser um palco. Qualquer lugar era palco para ele. Andando na rua, ele já estava sempre vestido, montado, como... Era um personagem mesmo. Chamava os olhares em qualquer lugar.

CB: Que requisitos você acha que os músicos tinham que ter, para tocar com ele? Fora o fato de estar disponível. Assim, por exemplo, eu lembro, ele nunca dizer para mim: "você errou..." algum tipo de coisa desse tipo.

Paulo Lepetit: Não, não. Não interessava muito isso, para ele. O principal era a dedicação ao trabalho. Ele perceber que a pessoa falava de trabalho, é 
importante, e eu quero fazer isso, e vou me dedicar a esse trabalho. O resto era... Ele pegou muita gente...

CB: Crua, não é?

Paulo Lepetit: Crua, no início. E formava. Formou muita gente, acho.

CB: Você o considera mesmo, uma pessoa que por sua capacidade, desenvolveu uma escola?

Paulo Lepetit: Ah, sim. Porque ele formou a maioria das pessoas. Ele não se interessava em chamar pessoas que tocassem super bem. Ele queria pessoas que manifestassem um interesse grande pelo trabalho dele. Aí, o resto, ele tinha paciência de esperar que a pessoa fosse pegando. Se o cara não sabia 0 que fazer, ele ensinava o que o cara iria fazer. Então interessava mais essa aglutinação de formar um grupo de pessoas interessadas e que, mesmo sem dinheiro - porque ele não tinha dinheiro - mantivessem uma fidelidade. $O$ trabalho era uma prioridade. Não tinha essa coisa: "ah, vai ter esse show, eu não posso fazer, porque eu tenho outro."

CB: Ah, não vou poder. Paga menos. Paga mais. Esse tipo de coisa não dava.

Paulo Lepetit: Às vezes, você deixava de fazer um trampo com mais grana, para fazer um sem grana nenhuma. Para não perder a boquinha. Senão, você saía fora. Era o interesse de fazer um trabalho em grupo. Estar ali, junto. Quer dizer, acho que o principal requisito era esse.

CB: A disposição.

Paulo Lepetit: A dedicação ao trabalho.

CB: Imagina ter passado anos formando a banda Isca de Polícia e depois ter que começar tudo do zero de novo, com As Orquídeas...

Paulo Lepetit: Acho que aí ele quis resgatar um pouco o controle, porque no final, na banda Isca já não controlava mais ninguém. Já era cada um, e aí, já não tinha mais essa, se aparecia um outro trabalho diziam: "desculpa, mas não vai dar..." Eu até fui bem, priorizei o trabalho dele bastante.

CB: Daí também tem essa coisa que daí cada um vai ganhando também, sua...

Paulo Lepetit: Suas asinhas...

CB: Suas asinhas, e aí também não...

Paulo Lepetit: É. Daí, você vai ficando maiorzinho...

CB: Não dá. Claro.

Paulo Lepetit: Não quer ser tão tutelado desse jeito.

CB: Claro.

Paulo Lepetit: Quer traçar seu caminho. 
CB: Claro.

Paulo Lepetit: Aí o Gigante foi lá com a Marisa (Monte). Depois o Luizinho (Waack). Mas a gente ia se virando também. Se alguém saia quando ia ter show, fazia sem. Fiz muito show, eu e ele, só. Ele, sozinho. Mas a gente continuou bastante tempo junto, e eu fazia com ele. Ou então eu, ele e o Luisinho. Eu, ele e o Tonho (Penhasco). Então, quer dizer, essa foi até a formação de base, do disco d Sampa Midnight.

CB: Que foi bem centrado nos violões.

Paulo Lepetit: É. É. A gente começou com os "acústicos".

CB: A "definição" de acústico é tocar sentado, você já reparou?

Paulo Lepetit: É. Então a gente fazia uma tonelada de shows, lá no Lira, assim, de...

CB: Só o trio. O trio, com ele?

Paulo Lepetit: É. Eu, ele e o Luisinho, e às vezes, o Tonho. E foi formando o repertório do Sampa Midnight. Ele tinha brigado com o Gigante, e com o Bocato, e não estavam se falando. Estávamos gravando o disco num estúdio, lá no centro. Eu esqueço sempre o nome desse estúdio. Mas tinham oito canais. Ele estava gravando, e foram usados sete canais. Ficou sobrando um canal. Aí encontramos na rua, o Bocato e o Gigante, os dois (risos). "Meu amigo, meu amigo, vamos lá gravar."

CB: Em um canal?

Paulo Lepetit: Em um canal. Trombone e bateria.

CB: Depois de ter gravado todas as bases?

Paulo Lepetit: Já tinha gravado tudo. Eles entraram em cima.

CB: Nem tinha clique. Nem se pensava em clique?

Paulo Lepetit: Que clique! Eles tocaram em cima, em um canal. Aquela beleza de som. Eu me lembro que um crítico, na época, disse: "esse trompete esganiçado...", nem parecia trombone.

CB: Às vezes, ele era muito prolixo, não? Era difícil a qualidade do disco. Porque não sei se você sente isso, por exemplo: dos shows ao vivo, o único que foi gravado ao vivo, que é o... As próprias custas S.A.

Paulo Lepetit: Praticamente...

CB: É só ele.

Paulo Lepetit: É só ele.

CB: Que tem um pouco da cara dele, do Itamar, da cara dos shows.

Paulo Lepetit: É. É. Foi tudo ensaiado. 
CB: Mas nos outros, existe muita coisa, muita informação musical.

Paulo Lepetit: Principalmente quando ele mesmo fazia... Depois que eu comecei a produzir, assim... mas eu só consegui mesmo, produzir de um jeito mais livre, depois quando ele já não estava mais. Porque ele dizia: "bota mais isso, chama não sei quem, põe mais isso, põe mais aquilo. Mais essa frase, mais aquilo..." Daí ficava...

CB: Poluído. Um pouco?

Paulo Lepetit: Ficava muito poluído.

CB: Porque ele tinha muita ideia.

Paulo Lepetit: Muita ideia, queria gastar todas, tanto em termos de preenchimento, se era um LP, ou se era um CD. Eram todos os segundos usados, e aí usar tudo de ideias.

CB: Que pudessem aparecer.

Paulo Lepetit: É. Não tinha economia de ideias.

CB: O que dava para ver é que para os shows também ia surgindo outras ideias. Daí ele ia modificando os arranjos. Então não tinha fim, não é?

Paulo Lepetit: É, mas o show era... Era... Ah, mas pelo menos era limitado àqueles instrumentos que estavam ali. Como não dava para ter aquele tecladinho... Então, o show tendia a ser mais limpo, claro. Mas os discos, a gente tinha muita dificuldade, quando eu comecei a gravar os discos. "Mais isso." "Mas não cabe. Não precisa..." Não tinha jeito. A última palavra, a primeira... A primeira, a segunda e a última, eram sempre dele (risos).

CB: Não havia jeito de você disfarçar, né? "Xi perdi aquela gravação...". Não tinha jeito.

Paulo Lepetit: Não. Então, quando eu fiz o primeiro, que eu produzi sozinho, que foi o Com Naná, ele é "minimal", têm pouquíssimas coisas, e a...

CB: Porque há na maneira dele tocar violão também, que mesmo fazendo base, daquela maneira, daquela maneira, com o polegar, é impressionante como têm vozes lá dentro.

Paulo Lepetit: Está tudo lá. Está tudo lá no violão. Tem vozes, tem ritmo. Tem tudo ali. Eu faço os arranjos muito a partir do que eu ouço do violão. Partindo daí. Tirando a rítmica do violão, que é aquela: tchique, tchique, tchacan, tchique, tchique, tchacan, já dá o ritmo.

CB: Já dá.

Paulo Lepetit: Você ouve, mesmo que ele esteja fazendo a base, você ouve coisas, ali. Ouve frases, ali.

CB: Umas vozes ali. Frases. Na maneira dele, às vezes, percutir mais umas cordas do que outra. 
Paulo Lepetit: Relar no violão.

CB: É. Relar. Impressionante.

Paulo Lepetit: Relar no violão. Mas com um grande suingue.

CB: Já ouvi comentários de violonistas admirando com sinceridade a maneira como Itamar tocava violão. Porque é uma coisa mesmo, da beleza de quem faz sem saber...

Paulo Lepetit: E aí, em shows, eu tentava resgatar isso, chamar algum músico. Não tem jeito. Mesmo músico que tocaram com ele... Chamei um dia, o Jean Trad, para fazer esse...

CB: Da Caixa Preta, você diz?

Paulo Lepetit: Caixa Preta. É. Fazer...

CB: O que vocês fizeram? A Isca?

Paulo Lepetit: De show, nós fizemos o primeiro, do Beleléu. Fizemos o primeiro, e depois, esse último. E o Pretobrás foi feito, praticamente inteiro com a banda e o Naná. Mas basicamente isso. Mas para fazer os shows, eu queria reproduzir um pouco disso, mas não teve jeito...

CB: Não tem, não é? Não tem como.

Paulo Lepetit: Não tem. Então, aí abandonei.

CB: Abandonou essa ideia mas de qualquer jeito, ela já tinha ido para os arranjos.

Paulo Lepetit: Sim. Para os arranjos. Tanto é que eu chamei o Jean para fazer violão no show, mas depois abandonei. Falei: "não, deixa, faz guitarra mesmo, e vamos fazer outra coisa..." Mas é muito difícil alguém reproduzir aquilo.

CB: Como é difícil reproduzir o modo de tocar de qualquer pessoa que seja, de qualquer músico. É possível imitar até certo ponto.

Paulo Lepetit: O gozado é que o violão do Itamar era muito simples. Não é um Yamandu Costa, que você vai falar... eu não consigo fazer isso. Tinham só dois acordes... mas vai tentar fazer igual (risos). Mas é isso mesmo.

CB: É muito louco essa coisa, de uma pessoa que não tem instrução formal.

Paulo Lepetit: Não...

CB: Como que você acha que isso...

Paulo Lepetit: Bom, eu também não tenho.

CB: Não, não. Tudo bem. Tudo bem. Você não tem...

Paulo Lepetit: Por isso que a gente se deu bem. Aliás, a banda, a maioria, não tinha. Não tinha essa coisa, mas é... 
CB: Mas eu digo assim, porque advém da escuta e da prática.

Paulo Lepetit: A originalidade. Eu acho que é uma coisa também, mais ou menos, como o Lenine, por exemplo, que o Lenine já ouvi falar também isso, ele não é um violonista... ele fala: "eu tiro..." Eu, ouvindo essa entrevista dele até no rádio, outro dia, eu falei: "é bem paralelo, essa coisa." O cara tem um estilo, uma maneira de fazer, de desenvolver, até por uma deficiência, às vezes, de não saber... Então o cara percebe uma forma, um caminho...

CB: Uma fenda ali, e vai.

Paulo Lepetit: É. E investe naquilo ali. Então, o Itamar acho que pensava... essa forma dele tocar, de compor, de cantar, que era tudo meio João Gillberto, então por isso que você ouve essas coisas. Porque se ele tocasse tchan, tchaca, tchan. Essas coisas que têm, essas sutilezas que saem do violão, não apareceriam. Se ele tivesse uma técnica de violão, ele não tocaria daquele jeito, o que atrapalharia a música.

CB: Claro. O fato de ter que fazer sair som. Qualquer instrumentista que vai estudar sopro, por exemplo, tem que estudar nota longa, saber como projetar o som. É muito definido no ensino formal, o que você se tem que fazer para obter a emissão de som. Para ser considerado um bom músico, você vai ter que...

Paulo Lepetit: Pois é. Exatamente. Você vê o Gigante também, como baterista. Todo baterista fala: "mas..."

CB: "Como esse cara segura a baqueta?"

Paulo Lepetit: E no começo, quando as pessoas não conheciam muito 0 Gigante, falavam: "pô, mas esse cara não toca bateria." E realmente, ele não tocava bateria. Ele era um percussionista, um cara de ritmo, que usava qualquer coisa que houvesse como instrumento. Não era aquela técnica de bateria. Por isso que ele teve um estilo inconfundível. Hoje, todo baterista, você ouve qualquer música, o Gigante tocando, você fala: "É o Gigante tocando."

CB: É. Ou quem não conhece, fala: "Bom, quem que está tocando aí?" Pessoa que chegou em uma...

Paulo Lepetit: Percebe que é uma coisa completamente diferente.

CB: Existe uma busca pela sonoridade que cada músico consegue se está atento, é uma busca sempre.

Paulo Lepetit: É mais difícil. É mais difícil, até, do que você tocar bem.

Clara Bastos: Claro. Porque tem muita gente que...

Paulo Lepetit: Tocar bem é só você estudar todos os dias. Agora, formar um estilo, formar uma...

CB: Isso é uma característica, acho que de música popular, não é?

Paulo Lepetit: É.

CB: Acho que basicamente. 
Paulo Lepetit: Acho que sim. É mais complicado ali. A maioria tira a partitura da frente, não consegue nada.

CB:. Eu gosto imensamente do CD que você produziu para a Caixa Preta. Eu não sei se é porque a gente está...

Paulo Lepetit: Acho que pela proximidade da linguagem.

CB: Pela proximidade da linguagem. Mas você percebe a música do Itamar como sendo uma música que pode ser tocada, mesmo se afastando da "linguagem" original que ele propunha?

Paulo Lepetit: Sim, sim. Por isso que eu achei bem bacana o disco produzido pelo Beto Villares (o Pretobrás II). Eu gosto...

Clara Bastos: Essa ideia do outro disco...

Paulo Lepetit: No começo, até quando a gente estava fazendo, fechando as produções, tinha um pouco essa coisa: "ah, mas o Beto não é da área...", mas daí eu falei...

CB: Você até afirmou que...

Paulo Lepetit: Por isso é bacana. Vão ser duas coisas, trabalhando com o mesmo material, porque era violão...

CB: Claro. Era exatamente o mesmo. Violão e voz.

Paulo Lepetit: Violão e voz. Que a gente partiu disso, tanto eu quanto ele. Então, para mim, era interessante aquilo, o que sairia de lá, o que sairia daqui, isso estimulou, acho que os dois, até a...

CB: A terem um cuidado. Quer dizer, já teriam normalmente.

Paulo Lepetit: Com certeza. Mas isso foi um plus, e a gente colaborou. Ele me chamou para tocar no disco dele, eu chamei ele para tocar aqui. Teve uma coisa bacana.

CB: Isso foi super legal. Eu digo que quem está mais impregnado da coisa do Itamar, tende a estranhar um pouco.

Paulo Lepetit: Sim. Mas eu acho que justamente, dá essa outra dimensão de que a música pode, sim, ser tocada e rearranjada... e principalmente o Beto, que tem muito essa linguagem também, de música minimal, em termos de acorde, em termos de variações. A música do Itamar continua. Ele foi mudando a forma de compor até, mas permaneceu isso, com dois acordes, quatro acordes, no máximo.

Clara Bastos: Isso. Uma estrutura de...

Paulo Lepetit: A estrutura da música, mas ele... ele mudou, depois que ele conheceu Leminski...

CB: Sim. Aí a questão da letra. Aí já poesia na canção. Você percebe mesmo. 
Paulo Lepetit: Foi se preocupando muito mais com esse lado...

CB: E menos com o arranjo, menos com a coisa do palco, da presença.

Paulo Lepetit: Arranjo, ele abandonou mesmo, depois de um tempo, arranjo ele abandonou. Foi deixando na minha mão, quando eu estava. Ele fazia desse jeito, violão e voz, e eu ficava trabalhando. Ele vinha, mas...

CB: Mas é interessante, porque é uma linguagem interdisciplinar, podemos pensar assim, ela permeia várias áreas. Para se fazer um show, uma música, uma gravação, tem muita coisa em jogo, mas essa linguagem, ela está sempre costurando as coisa. O Itamar abandona, mas a linguagem continua permeando.

Paulo Lepetit: Ah, não, mas ele abandonou, acho que foi por confiança de saber que as pessoas que estão em volta entenderam já como funciona a linguagem. Acho que todo mundo que tocou com ele passou por esse intensivo.

CB: Depois tudo bem. Agora, se depois...

Paulo Lepetit: Aí, agora, vai aí, faz o seu negócio.

CB: Às vezes, vejo a música dele ser tocada por aí sem dinâmica. Não estou querendo que você concorde, mas a música dele não fica soterrada assim? O que a gente tem que prestar atenção na música do Itamar, interpretá-la, mesmo que tenha outra roupagem? Entendeu a pergunta?

Paulo Lepetit: Respeitar as sutilezas da música. E acho que nessa ânsia de botar o seu...

CB: A sua personalidade naquele som lá.

Paulo Lepetit: A sua personalidade ali. E aí se perde. Mas isso, com certeza, acho que a maioria tende a se perder nisso. Acho que a pessoa tem que ter uma vivência, para conseguir fazer que a música permaneça, e não o estilo da pessoa...

CB: Daquela pessoa que vai colocar um sobretudo, sobre aquela coisa.

Paulo Lepetit: Exatamente. A Zélia sabe fazer isso super bem. Faz. A Cássia...

CB: É o entendimento da linguagem?

Paulo Lepetit: Entendimento, um respeito à linguagem. Aquela linguagem tem que ser respeitada.

CB: Mas isso aí não tem nada a ver com o moderno?

Paulo Lepetit: Não. Não.

Clara Bastos: Por exemplo, aquilo que você falou, legal, que você curtiu o disco do Beto... 
Paulo Lepetit: Porque eu gosto do estilo dele, independente de... É moderno. É moderno, mas eu já gostava do disco da Céu, as produções dele, eu gosto como...

CB: Entendi. Entendi.

Paulo Lepetit: Então eu queria ouvir o que o Beto faria com aquilo, com o mesmo tipo de material, saindo do mesmo lugar...

CB: E porque também, ele não tem a postura daquele produtor que vai soterrar quem está vindo.

Paulo Lepetit: Exato. Embora ele tenha um estilo forte, bem definido, mas...Eu acho que ele teve esse respeito. $\mathrm{E}$ eu gosto bastante.

CB: Quer dizer, na verdade, a música do Itamar pode ser executada. É claro, quem quiser tocar, pode tocar. Ninguém é dono de nada. Mas o que você vê na linguagem dele como sendo essencial? Se é que existe essência. Por exemplo, essa questão da dinâmica. Mas tem haveria mais alguma coisa que pode ser...

Paulo Lepetit: Talvez, não seja nem só a dinâmica. Quer dizer, não seja a dinâmica tão essencial assim. Eu acho que é entender o Itamar, não como uma música isolada, mas entender ele como um artista, como uma coisa geral. $\mathrm{E}$ respeitar isso. Acho que tem que respeitar a composição principalmente. Se vai ser um rock'n roll, uma coisa ou não, acho que tem que... É meio difícil explicar.

CB: Entendi. A gente também não sabe direito.

Paulo Lepetit: Mas eu acho que tem que entender o conjunto da coisa.

CB: Porque, no caso dele, é uma obra em que não se consegue desvencilhar muito a composição do arranjo. Não é? Seria correto falar isso?

Paulo Lepetit: Sim. Sim. Quer dizer, a preocupação principal dele, era de que o arranjo fosse diferente, fizesse parte do negócio, mas não que vestisse a música de uma forma que ninguém conseguisse' enxergar a música lá, entender a letra, que chamasse a atenção de uma forma a tirar esse foco da composição, em si. Porque as músicas, em si, já funcionam bem para caramba. Com violão e voz, funciona. Então, tem produções que você fala: "Putz, como é que eu vou fazer aqui, para criar alguma coisa interessante nessa música?" Ali não. Você pode deixar. Você poderia deixar...

CB: Têm umas músicas que você fala assim: "Meu Deus, mesmo se eu chamar..."

Paulo Lepetit: Se chamar Hermeto Pascoal... Mas ali não. Você podia deixar as músicas... Por isso que é uma "grande responsa" você fazer um arranjo e respeitar. Quer dizer, para mim, nesse disco, foi simples, porque eu sabia, é possível pensar um pouco como ele pensaria, até, para fazer.

CB: Claro.

Paulo Lepetit: Então são anos de aprendizagem. Então alguém que chega de fora e vai fazer uma... 
CB: É muito difícil, não é?

Paulo Lepetit: É muito difícil. Não é nem por má intenção: "não, eu quero que o meu estilo se sobreponha." Não é. Não sabe como fazer, porque não tem vivência com...

CB: Eu estou pensando, mesmo, sobre a questão da composição do Itamar. É isso, na verdade, que eu vou tentar estudar. Assim, a composição dele, ele... ela tem elementos que não, necessariamente, estão em uma partitura. Não caberiam em uma partitura. Isso é óbvio.

Paulo Lepetit: Sim.

CB: Assim, a música, ela extrapola até, a coisa da própria música. Quero dizer, mesmo que tenha uma pessoa tocando com o violão, ela estabelece outro tipo de conexão. Por isso, talvez, seja tão forte o trabalho do Itamar? Será? Você que tem que entender a linguagem. Tudo bem, você entendeu a linguagem. Mas de outros músicos, de outros compositores, você também tem que entender a linguagem, mas parece que ela nunca tem... Ela não é limitada.

Paulo Lepetit: É. Até isso que a gente estava falando, do violão, das coisas, acho que nem era... Não sei. Em se tratando de Itamar, se você pode falar que não era muito consciente. Acho que era...

CB: É e não é, também.

Paulo Lepetit: Mas essa coisa de estar tudo ali, e aí sim, entra a dinâmica. Ele não poderia tocar, ou cantar muito gritando, que é coisa que a gente fazia, e nem tocar... Por isso que a música, ele, com o violão, já era suficiente. Porque está ali. Aí você tem que prestar atenção, justamente, no subliminar. É isso que a gente está falando, das vozes que aparecem, de um violão base, você fala: "Mas onde está vindo essa frase?" E o ritmo que sai dali também. Os arranjos, às vezes, depois, no final, eu acabo tirando o violão. Porque você faz outras coisas, o violão nem precisa mais.

CB: Aquilo é tipo um DNA que o cara deixou.

Paulo Lepetit: Isso. Você distribuiu aquilo. Você pôs a levada da percussão, da bateria. Já está fazendo aquilo, e aí... Mas eu faço sempre questão de deixar um trecho, às vezes no início, ou no meio, ou no fim.

CB: Claro.

Paulo Lepetit: Se você prestar atenção, sempre tem ele... Se você distingue o violão, e a voz, justamente para mostrar esse caminho que...

CB: Partiu daí.

Paulo Lepetit: Saiu dali. Tudo veio de lá. E fazer isso com tão poucos elementos, que ele compunha com poucos elementos, de...

CB: De harmonia. De Acordes. 
Paulo Lepetit: Exatamente. Para mim, o desafio sempre foi, nos arranjos, fazer duas, três partes, parecendo que mudaram. Parece que mudou, mas não mudou nada. Você pode tocar a música inteira. E que era o jeito que a gente gravava. Quando começou essa coisa de gravação digital, que eu comecei o estúdio, há 20 anos, quando a gente começou a gravar junto, aí ele percebeu essa facilidade, que era, você colocar o clique. Aí ele tocava duas vezes o negócio e dizia: "já deu, não é?"

CB: Também tinha preguiça, não é? (risos)

Paulo Lepetit: Já deu. Então ele falava: "então, põe 3 minutos. 3, 4 minutos para mim." Um minuto e loop. Daí ele pegava o caderno, e cantava a música do começo ao fim, tendo A e B na música.

CB: Ou seja, mais sintético ainda?

Paulo Lepetit: Sempre muito sintético. Aí depois, no arranjo, que você fazia parecer que tinha a parte A, que tinha B. Não digo nem refrão, porque refrão nunca existiu muito, na música dele (risos). Não sei se saberia lembrar algum refrão (risos). Mas então é isso, é muito simples. É muito cíclica. A música sempre...

CB: Tem essa coisa africana mesmo. Por mais que ele não ficasse falando sobre essa origem, mas está totalmente.

Paulo Lepetit: Não precisava, né? (risos).

CB: Não, porque tem uns caras que ficam falando.

Paulo Lepetit: É.

Clara Bastos: Tinha alguns arranjos da época em que a gente começou a ensaiar, que, a gente não sabia onde estava o um, o primeiro tempo do compasso.

Paulo Lepetit: É, isso. Sim.

CB: A gente até brincava: "Cadê o Wally? Onde está o Wally?" Porque justamente, a música africana não tem compasso, o som é polirritmia, tal. Mas acho que de todas as músicas, que eu ouvi, acho que não tem nenhuma em que o compasso não seja quatro por quatro. Tem uma que tem cinco no meio, lá...

Paulo Lepetit: Músicas dele que não sejam quatro?

CB: Que não seja quatro por quatro. Ou seja, que não seja binário. Mas mesmo assim, você...

Paulo Lepetit: A maioria são quatro. Tem uma ou outra em cinco...

CB: É. Mas assim, é raro. Acho que, se não me engano, tem uma. Dessas gravadas, todas...

Paulo Lepetit: Estou tentando... 
Clara Bastos: A fom, fim, fam, fim, fum?

Paulo Lepetit: Não. Tem uma música que era em cinco, que a gente tocava. Bacana. Em um desses discos aí.

CB: Que não está gravada?

Paulo Lepetit: Não. Está gravada, sim. Ou será que não está?

CB: Vai ver que não está. Eu não estou lembrando. Enfim...

Paulo Lepetit: Preciso lembrar essa música.

CB: Ou seja...

Paulo Lepetit: Mas era quatro...

CB: Mas essa maneira dele lidar com o tempo musical, com poucos elementos, de você não saber onde é a cabeça, é tudo invertido...

Paulo Lepetit: Exato. É.

CB: Batera tudo...

Paulo Lepetit: Tinha uma preocupação em não fazer o convencional. Então isso eram os ensaios... aqueles ensaios para entender justamente a frase, e às vezes, você achava...

CB: Que aquela frase... era num lugar.

Paulo Lepetit: E não era. E você entrava errado: "Ah, não é aí." "Mas não é aqui, meu Deus? Onde é então?" Aí começa a travar, porque daí você não conseguia. Aí depois, quando entrava, ia. Aí entra no mantra. Mas você distraiu um pouquinho, errou o lugar, vai tudo atravessado.

CB: Atravessa mesmo. Ninguém percebe. Se conserta, na verdade, para 0 ouvido do senso comum.

Paulo Lepetit: É, é. Mas vai errado até o fim. Depois que entrou, para você inverter...

CB: Acho que é isso, Paulinho. Deixa eu ver se tinha mais alguma coisa.

Paulo Lepetit: Não tem problema. Até depois, se você lembrar alguma coisa...

CB: Se eu lembrar alguma coisa...

Paulo Lepetit: Você me manda e-mail, ou me liga, ou a gente marca outra.

CB: Ah sim, e quando apareceram os dois baixos, o que você acha? Você estranhou?

Paulo Lepetit: Quando ele falou que ia fazer com dois baixos... Ele sempre tinha essa ideia.

CB: Ah, ele já tinha essa ideia? 
Paulo Lepetit: Já tinha. Ele já tinha essa ideia antes. E eu acho muito complicado dois baixos. Não me lembro de ter visto, nunca fui a muitos shows...

CB: Para poder até...

Paulo Lepetit: Até para ver. E quando vi, eu estava mordido, não queria gostar (risos). Mas eu acho, o baixo é muito... tanto é que no mundo é difícil ter alguma formação com dois baixos. A não ser que seja muito bem arranjado, muito bem dividido.

CB: Tem dois arranjos, que são do Mário Campos no Bicho de 7 cabeças com as Orquídeas, acho que lá a coisa que ficou bem resolvida.

Paulo Lepetit: Tem que, pelo menos, dividir as regiões, mais agudo, mais grave.

CB: Depois de muito ouvir, eu consigo... como essa história que a gente falou do violão, eu consigo ouvir uma coisa bem interessante nessas construções...

Paulo Lepetit: E ele fazia os dois baixos, o Itamar, nessa época?

CB: Sim ele fazia. Bolava as duas linhas. Mas de qualquer jeito, nos shows é preciso ter muita atenção para que o som soe bem.

Paulo Lepetit: Pois é. Se você tiver em um lugar ideal, que é muito difícil, você tem que ter um som ideal. Então é uma coisa que complica bastante, conseguir um resultado audível, bacana. Não que seja impossível, mas realmente o baixo é um instrumento bem difícil de se fazer esse divise. Com os outros, eu acho é mais simples. Agora o baixo é espinha dorsal de um arranjo. Pelo menos na nossa concepção, que é assim, mais desenvolvida. Não é aquela coisa de baixo - bumbo, complemento. 
Anexo 3: CD - 43 faixas de áudio

\begin{tabular}{|c|c|}
\hline Faixa 35 & Adeus Pantanal \\
\hline Faixa 43 & Agora é que são elas \\
\hline Faixa 27 & Amanticida \\
\hline Faixa 3 & Amigo Arrigo \\
\hline Faixa 14 & Anteontem, melô da U.T.I. \\
\hline Faixa 24 & Aranha \\
\hline Faixa 29 & Baby \\
\hline Faixa 1 & Batuque \\
\hline Faixa 28 & Beijo na boca \\
\hline Faixa 13 & Cultura Lira Paulistana \\
\hline Faixa 23 & Custa nada sonhar \\
\hline Faixa 42 & Devia ser proibido \\
\hline Faixa 4 & Diversões eletrônicas \\
\hline Faixa 15 & Dor elegante \\
\hline Faixa 25 & Enquanto penso nela \\
\hline Faixa 40 & Estranha ideia \\
\hline Faixa 19 & Fico louco \\
\hline Faixa 5 & _Infortúnio \\
\hline Faixa 20 & In the morning \\
\hline Faixa 34 & Laranja madura \\
\hline Faixa 17 & Luzia \\
\hline Faixa 22 & Milágrimas \\
\hline Faixa 8 & Missa in Memorian (Kyrie) \\
\hline Faixa 9 & Missa in Memorian (Gloria) \\
\hline Faixa 10 & Missa in Memorian (Credo) \\
\hline Faixa 11 & Missa in Memorian (Sanctus) \\
\hline Faixa 12 & Missa in Memorian (Agnus Dei) \\
\hline Faixa 16 & Navalha na liga \\
\hline Faixa 31 & Nega música \\
\hline Faixa 7 & Nego Dito \\
\hline Faixa 6 & Negra melodia \\
\hline Faixa 39 & Noite torta \\
\hline Faixa 32 & Orquídeas \\
\hline Faixa 18 & Peço perdão \\
\hline Faixa 26 & Quem canta seus males espanta \\
\hline
\end{tabular}


Faixa 30 Santo de casa

Faixa 36 Sexto sentido

Faixa 2 Sonhei que viajava com você

Faixa 33 Totalmente à revelia

Faixa 37 Tristes trópicos

Faixa 41 Variações

Faixa 21 Venha até São Paulo

Faixa 38 Vê se me esquece 
Anexo 4: DVD - show

Faixa única, trecho do show realizado no Instituto Cultural Itaú, em 03 de agosto de 2002. Apresentação do espetáculo, canções Dor elegante e Anteontem - Melô da U.T.I, ambas à capela. 